\title{
PACIFYING LEVIATHAN: BACK TO BASICS IN PEACE-BUILDING OUT OF CONFLICT
}

\author{
BY JESSIE WILLIAMS
}

\begin{abstract}
A THESIS
SUBMITTED TO THE VICTORIA UNIVERSITY OF WELLINGTON IN FULFILMENT OF THE REQUIREMENTS FOR THE DEGREE OF

MASTER OF ARTS
\end{abstract}

VICTORIA UNIVERSITY OF WELLINGTON

$2015^{*}$

* This date refers to the year a final copy of this work was deposited in the VUW library. This thesis was completed in 2010. 


\section{Abstract}

This thesis focuses critically on contemporary theory and practice of peace-building where there has been conflict. The commonality of the resumption of violence after peace processes in many recent examples, suggests that both theory and practice have not worked as intended. The thesis explores insights that might improve the odds that governing institutions (or, more particularly, the people who work in them) can put aside violence. In the terms used in this thesis: how might Leviathan be pacified? Therefore, the thesis deals with basics evident in all recorded (and probably pre-historic) human experience. For the modern states of Western Europe and North America, pacifying Leviathan followed centuries of conflict (including two world wars), interspersed with governance reforms and constitutional adjustments. The process is ongoing, but by the middle of the $20^{\text {th }}$ century "the liberal state" clearly emerged, with features that included constitutions, the rule of law, the protection of human rights and the market system. There appeared to be a widespread view after World War II that the liberal state apparatus' essence could be written down in documents, transplanted into many different historical and cultural contexts and would work much as the model predicted i.e. was easily reproducible, perhaps infinitely, even in smaller and smaller versions. From 1945 to 2010, the numbers of states at the United Nations almost quadrupled (51 to 192). Member 193 (South Sudan) may emerge from decades of conflict in 2011. In all that state formation, the optimistic view was that the new documents and institutions would provide structures within which political and/or ethnic competitors/combatants would engage in non-violent political competition. In this thesis, "reverse-engineering" is the term given to this notion. Such optimism was severely dented by the experiences of many newly-independent states in the mid-late $20^{\text {th }}$ century. As violence escalated in new and existing states all over the world after the Cold War ended (taken, for convenience, as 1990), reverse-engineering remained at the core of the formula for peace-building after conflict. As with the postcolonial period, liberal peace-building since 1990 have also been repeated failures to work as intended, including the resumption of conflict. The most fragile states have posed the hardest problems, not only for the suffering citizens but for the international community seeking how best to help. 
With this in mind, and accepting that each state and society is unique, this thesis sets out building blocks for alternative approaches. It does not suggest there are simple answers in pacifying Leviathan, either generally or in relation to any particular example. If it is indeed possible in any place (e.g. Haiti) to reduce ongoing conflict, the argument is that these blocks should be amongst the foundations of theory to inform practice.

The core thesis is thus that the chances of pacifying Leviathan might be significantly improved if domestic and international actors:

- Adopt a conflict transformation approach to guide theory and practice;

- Come to terms with groupism - how/why humans bond into groups and the potential this poses for violence and peace;

- Understand the importance of receptivity - the notion that critical masses of key actors should squarely face (often when they have become exhausted by) the consequences of violent competitiveness and seek alternatives;

- Translate receptivity into learned constitutionalism - learning to govern by rules amongst sufficient actors; and

- Develop international assistance guided by the above perspectives, and which, with the consent of the peoples concerned, find ways to stay appropriately engaged for the time needed to strengthen the factors that should pacify Leviathan.

The thesis does not focus on future strategies of conflict-reduction - such as economic development to give people stakes in the society, along with disarmament of combatants. Many other studies explore these. Here, the exploration is of the nature of human society, informed by history, examples, case studies and a sweep of cross-disciplinary analysis. Understanding why pacifying Leviathan is so hard is the basic first step, which forms the bulk of this thesis. Putting such understanding into practice involves many further steps. Important as these might be for current and future policy and practice in peace-building, their full development is beyond the scope of this thesis. Some suggestions are made, especially in the conclusion, but elaboration will have to await further work. 


\section{Acknowledgements}

This thesis would not have been possible without the encouragement and scholarly influence of my supervisor, Dr Andrew Ladley. The ideas behind this research reflect discussions started in supervised undergraduate research in 2003 and which kept developing as his international work encountered its key themes. Some of this thesis was directly prompted by work done together during its gestation. In particular, part of Chapter 7 draws on a joint conference paper we delivered at the Third Australasian Conference on the Economic and Politics of War and Peace held at the University of Sydney in June 2009. A revised version was published in a book compilation (Ladley and Williams 2010). The thesis has also benefitted from detailed discussions, comments and suggestions of terms, concepts and arguments across many drafts and pots of green tea, as I wrestled with the weighty issues that this study raises. While I acknowledge the depth of that influence, and the other contributions outlined below, I accept full responsibility for the final product.

Contributions to an extended study come in many forms and I express warmest thanks to the many wonderful people who have been part of my academic growth at Victoria University of Wellington, some of whom were colleagues at the Institute of Policy Studies: Dr Jonathan Boston, Dr Paul Callister, Chloe Davenport, Derek Gill, Barbara Gillespie, Dr Bob Gregory, Sir Frank Holmes, Zoe Lawton, Sean Mackesy-Buckley, Dr Gabrielle Maxwell, Darren Morgan, Dr Matthew Palmer, Ken Piddington, Maureen Revell, Dr Nestar Russell, Lyne Todd, Michelle Walmsley, Nicola White, and Dr Amanda Wolf - among others, who I hope will not mind being thanked collectively.

I also acknowledge my parents, Kate and Trevor Williams, for instilling in me the value of education - the power of knowledge generally - and assisting me in that pursuit; also Sarah Williams, Jon Stoddart and little Jack, for their encouragement and love. I will be eternally grateful to my Shigeeda family, for numerous kindnesses. I especially thank my husband Akio for unquestioningly championing me, supporting me both financially and when a "boost" was needed, for plenty of yummy food and welcome distractions - and most importantly for our own joint 2010 project, our baby son Juro Ben Williams 
Shigeeda. This is for you, our son, with the hope that you might one day read it in a climate of positive peace prevailing in more parts of a troubled world. 


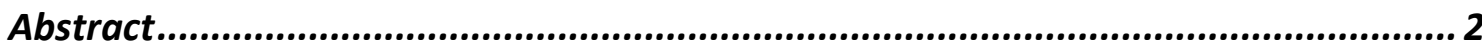

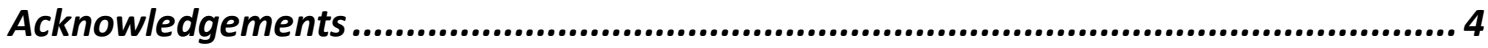

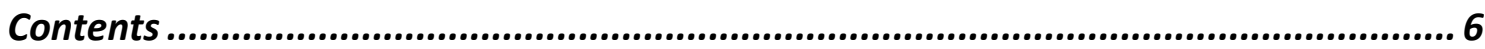

1: Pacifying Leviathan: the search for new insights .......................................... 11

I. INTRODUCTION__ 11

II. THE DIFFICULTY IN SUSTAINING 'PEACE' IN POST-CONFLICT SOCIETIES ___ 12

III. LIBERAL-PEACE DRIVEN POST-CONFLICT STATE-BUILDING PRACTICES__ 15

IV. RESEARCH AIMS

V. MOVING FROM THE LIBERAL-PEACE APPROACH TO THE BUILDING BLOCKS OF PACIFYING LEVIATHAN — 21

VI. DEFINITIONS — 30

VII. METHODOLOGY__ 32

VIII. BIAS, LIMITATIONS AND CAVEATS __ 33

IX. OVERVIEW OF CHAPTERS _ 37

2: The current dominant strategy of liberal peace-building ..................................... 39

I. INTRODUCTION__ 39

II. ENLIGHTENMENT ORIGINS OF THE LIBERAL PEACE __ 39

III. THE ASCENDENCY OF LIBERAL INTERNATIONALISM IN THE $20^{\text {TH }}$ CENTURY AND THE SEARCH FOR STATE MODELS FOR PEACE___ 43

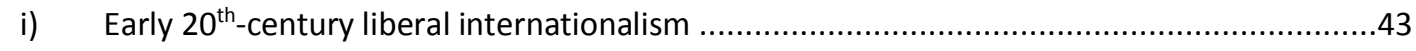

ii) Search for state models to deal with conflict.................................................................4

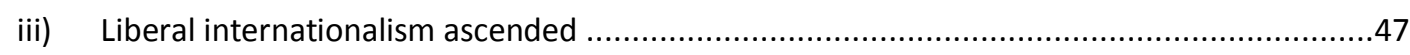

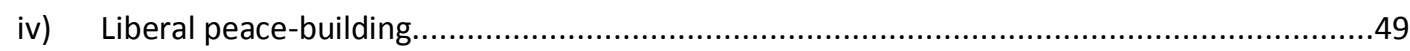

IV. UNITED NATION'S PEACE-BUILDING: LIBERAL PEACE-BUILDING IN PRACTICE __ 53

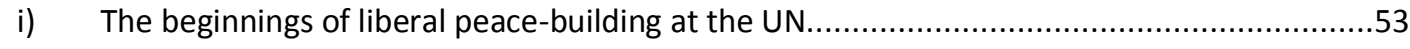

ii) Re-definition of state sovereignty (or The Responsibility to Protect) ................................55

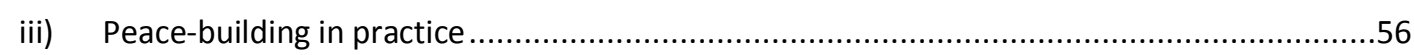


iv) The UN's peace-building record and lesson learned................................................ 58

V. BEYOND CRITIQUES OF LIBERAL PEACE-BUILDING__ 64

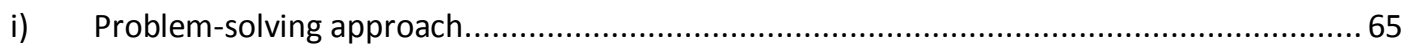

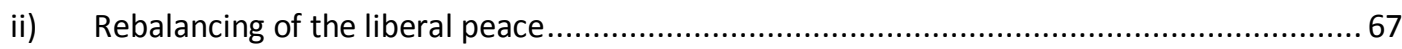

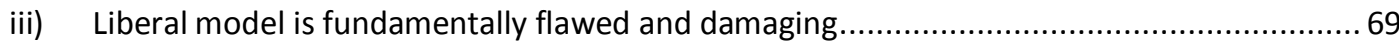

VI. FINDING COMMON GROUND IN THE LITERATURE TO REVEAL A GAP FOR RESEARCH___ 71

i) Reconciling local ownership and peace-building practice: emerging from the critical literature

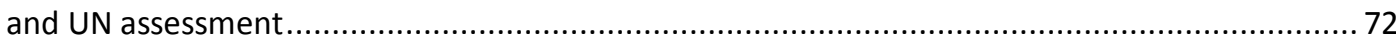

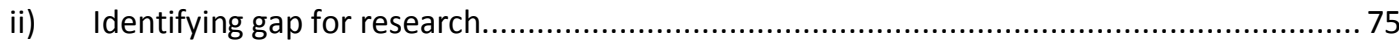

VII. CONCLUSION _ 76

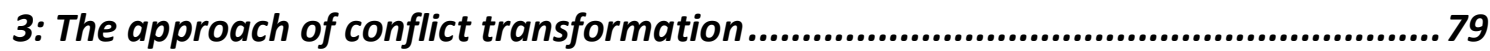

I. INTRODUCTION

II. WHAT IS CONFLICT TRANSFORMATION? 79

i) Conflict approaches: management, resolution and transformation.............................. 80

ii) Theoretical influences of conflict transformation................................................... 83

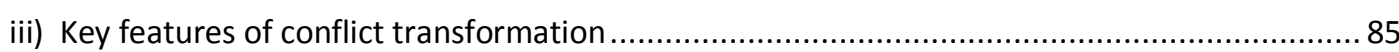

III. MOVING BEYOND THE STATUS QUO: ADDRESSING THE UTOPIAN PERCEPTION OF CONFLICT TRANSFORMATION THEORY__ 90

IV. CONCLUSION _ 92

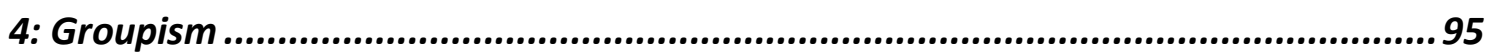

I. INTRODUCTION _ 95

II. THE MYTH OF HUMAN NATURE

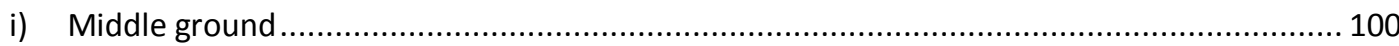

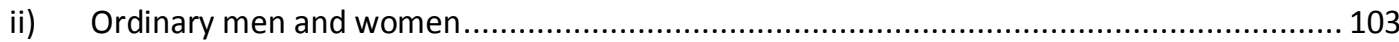

III. GROUP IDENTITY _ 104

i) The assumption of ethnic intransigence ............................................................ 106

ii) Shapers of group identity - human needs and collective fears ................................... 111

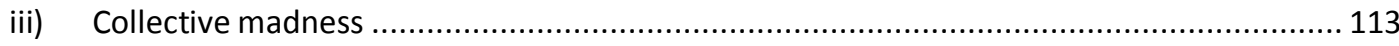

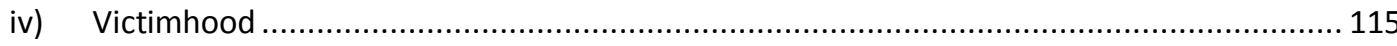

IV. POWER SHARING $\quad 118$

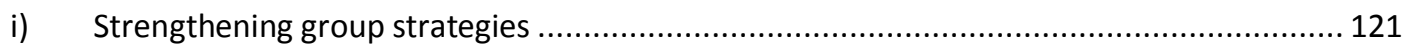

V. CONCLUSION _ 124 
I. RECEPTIVITY, AN INTRODUCTION 127

II. DECREASING VIOLENCE 129

III. DEVELOPED-WORLD RECEPTIVITY 130

IV. RESIDUAL VIOLENCE AND RULE BREAKING 133

i) Man's capacity to do violence. .133

V. FIGHTING IN THE MIND AND SPOILERS 137

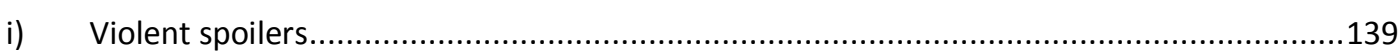

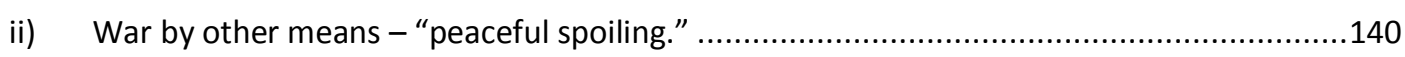

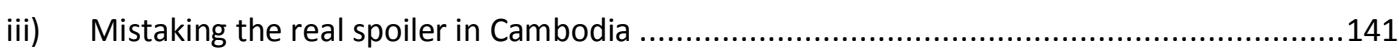

VI. BEGINNING THE SHIFT FROM WAR BY OTHER MEANS TO MAKING BELIEVERS IN THE PEACE PROCESS 144

i) Northern Ireland - tiring, holding together, moving on, maybe? .....................................146

VII. BOUgAINVILLE - FROM CIVIL WAR TO “PEACE BY PEACEFUL MEANS.” — 151

VIII. CONCLUSION _ 157

6: Learned Constitutionalism - learning lessons for governance ............................ 159

I. LEARNING LESSONS__ 159

II. CONSTITUTIONS AND CONSTITUTIONALISM __ 161

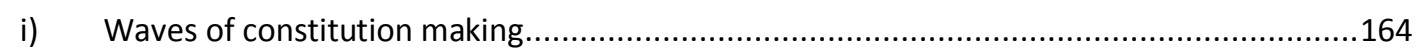

ii) Uganda: constitution making after independence ..................................................... 166

III. ROMANTICISING CONSTITUTIONS 168

i) America's Independence Constitution - an evolution..............................................169

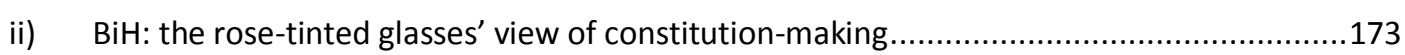

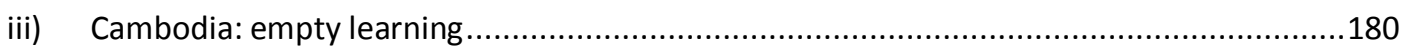

IV. AGREEING ON A USABLE PAST AND AN IMAGINED FUTURE__ 181

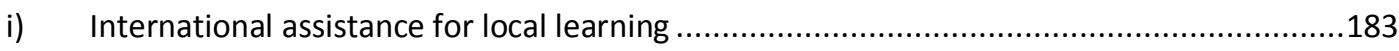

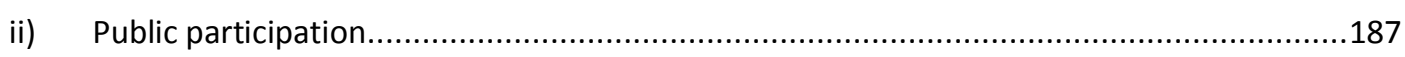

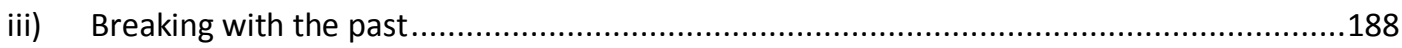

iv) South Africa's constitution: "a ringing and decisive break with the past." ......................190

V. THREATS TO LEARNING STABILISING __ 194

VI. CONCLUSION _ 198 
I. INTRODUCTION _ 201

II. REORIENTATING THE FORMULA-STATE MODEL___ 203

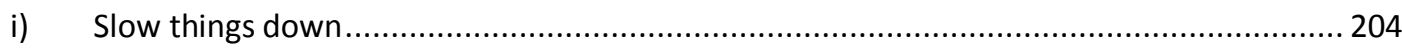

ii) Top down approach: contrasting Cambodia and Bougainville ......................................... 205

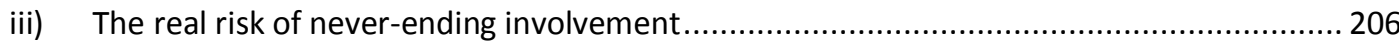

III. THE INTERNATIONAL SOCIAL COMPACT__ 210

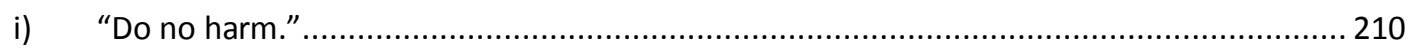

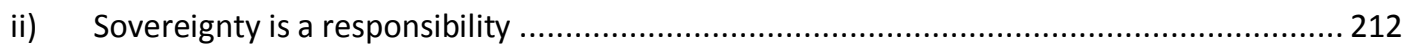

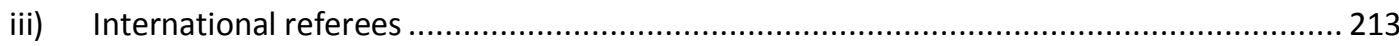

IV. INTERNATIONAL ASSISTANCE FRAMEWORKS _ 215

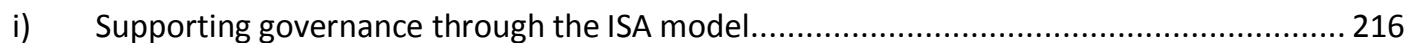

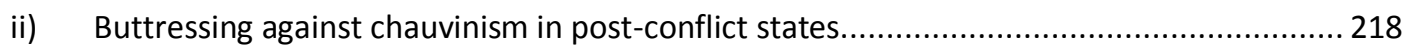

iii) Comparing THE ISA Model with the Regional Assistance Mission in Solomon Islands (RAMSI) 222

iv) Building immunity against regression and support for RAMSI ........................................ 225

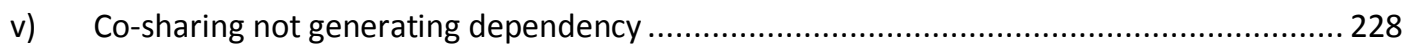

V. CONCLUSION _ 229

8: Conclusion ............................................................................................................... 231

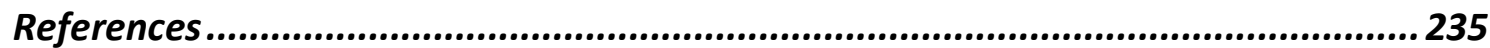





\section{1: Pacifying Leviathan: the search for new insights}

\section{INTRODUCTION}

This thesis is concerned with the beginnings of peace-building out of conflict in societies emerging from civil war (or some similar intrastate conflict). How the lessons of the immediate past combined with a willingness to manage competition in society in nonviolent ways is then articulated in a shared vision for the future during the post-conflict "pause" - the period immediately after a peace "settlement" (peace agreement or comprehensive ceasefire) and before formal state-making - is not well understood. These questions are important because many externally driven peace-building efforts made since the end of the Cold War (taken for convenience as 1990) have failed. In part, this may be through their reliance on liberal peace-building solutions brought in from "above" and "outside".

It is doubtful that conflict will be transformed without the deliberative insights and learning of the society in question in the crucial period post-settlement, which is before rushed state-making or the like when the baubles of the state may confuse the renegotiation of peace. The particulars of learning and agreement as the Leviathan pacifies will be unique to any society (and on-going). However it is reasonable to postulate that the chances of conflict transforming from former conditions of endemic conflict to ones of constructive or "positive" peace requires the mass of individuals, leaders, ex-combatants, victims (all of whom firstly need to reorient from violence) to take the time to reconcile, to agree upon new rules for controlling conflict and competition in society and in doing so become believers in the process, discuss the issues, strengthen the rules, defend them, and remember.

This chapter goes on to describe more fully the difficulty in sustaining 'peace' in postconflict societies and the problems associated with liberal peace-building practices, the research aim, the focus of the research - pacifying leviathan, the meanings of key concepts, methodology, and an overview of the structure of the full report to follow. 


\section{THE DIFFICULTY IN SUSTAINING 'PEACE' IN POST-CONFLICT SOCIETIES}

Although overall violent conflict appears to be lessening worldwide, interstate conflict has been supplanted by frequent internal violence and civil wars with severe levels of human displacement and deliberate targeting of civilians in new and existing states all over the world since the end of the Cold War (Erikson and Wallensteen 2004; Human Security Centre 2005, 2011). Violence and war pose hard problems not only for those suffering from their effects but also for the international community seeking to help. In the period immediately following the 'end' of a conflict and some form of settlement, the challenge is to realise stable, enduring, peaceful governance. To some degree, the violence will have led to significant damage and, perhaps, the full collapse of governance structures. So, despite the 'pause' that peace treaties or ceasefires signal, in the aftermath of serious politically related violence on a wide scale, further violent outbreaks often occur.

In such cases, it can be assumed that some assistance from the international community may be warranted. Haiti, Liberia, Bosnia and Herzegovina (BiH), Kenya, Zimbabwe, East Timor and the Solomon Islands are amongst post-conflict states where there has been no easy transition from war to peace. After the 2008 elections, for example, Zimbabweans waited while a power-sharing agreement was negotiated between Mugabe's ZANU-PF and the opposition Movement for Democractic Change, who believed they had won. The resulting Global Political Agreement may have provided a little political and economic stability (Connolly 2011) but seems to be operating on borrowed time with major risks of a resumption of violence (Kandemiiri et al. 2010). In BiH an internationally imposed and administered 'peace' is close to two decades old. The Serb entity continues to threaten to move away from the current power-sharing administrative arrangements and push (perhaps violently) for independence (International Crisis Group 2010). Such threats are destabilising and may cause the frustration felt by the other groups to spill over into violence (International Crisis Group 2011). These examples indicate that 'post-conflict' may connote that the conflict has 'ended', yet as explained by Junne and Verkoren (2005: 1), the term is simply "shorthand for conflict situations, in which open warfare has come to an end". In these ambiguous contexts, although an enduring 'peace' is possible, settlement may yet fail, and armed conflict may continue, restart, or intensify (for further discussion on the distinctions: von Bogdandy et al. 2005). 
At this most general level, the issues are clearly not new. Violence has been so prevalent in human affairs that after-war-rebuilding (of everything) has occupied leaders and peoples across human history, written and unwritten. ${ }^{2}$ The issues were particularly evident in the $20^{\text {th }}$ century as the sovereign state emerged from various conflicts (including two World Wars) as the dominant form of human governance. From 1945 to 2011 the numbers of states at the United Nations (UN) almost quadrupled (from 51 to 193). Associated documents and institutions were thought to provide structures within which political and/or ethnic competitors/combatants would engage in non-violent political competition. Whatever hopes were held for peace flourishing in the post-war period, they would have been severely dented by the experiences of many newly independent states in the mid to late $20^{\text {th }}$ century. Failures continue in the post-Cold-War period with observed resumptions of conflict (Berdal 2009; Call and Cousens 2008; Doyle and Sambanis 2006).

Post-conflict peace-building as the dominant internationally driven mechanism to build peace in the post-Cold War period has created fragile states and institutions dependent upon foreign support and subject to contests over power and corruption. As Azar (1990) and others (Azar and Burton 1986; Collier 2000; Toft 2009) have observed these intractable intrastate conflicts share some characteristics in addition to weak state systems, including group identity-based needs and fears and the associated problems of group identification, where the distinction between combatants and civilians is blurred, and immense suffering ensues, where competition over resources is evident, and where settlements have been negotiated - a finding most perturbing for international practitioners in their efforts to assist post-conflict societies and strengthen peace.

Sustained violence has produced problems and challenges for new forms of governance. Inevitably, there were some "winners" in some conflicts: people and institutions that handled the post-conflict period "better", emerging with control over armies, resources or indeed, the state apparatus (e.g. in Russia). But there were also plenty of "losers": the dead and the injured and their families, victims of fundamental rights abuses, displaced

\footnotetext{
${ }^{2}$ The oft-cited biblical reference (Isaiah 2:4) that God would preside over the ending of wars between peoples, who would beat swords into ploughshares and spears into pruning hooks, testifies not least to the endurance of the issues across thousands of years.
} 
civilians, destroyed economies, starving peoples, refugees, bitter communities, angry rivals. Most significantly, the evidence is that although violence is often reduced in the short term, the fighting was more accurately paused i.e. significant proportions of the leaderships, at least, were still fighting in the mind, ${ }^{3}$ whilst appearing to go about the formalities of building peaceful constitutional governance. Thus conflict re-emerged in many of the areas concerned in a cycle, summarised below:

\section{Figure 1: The conflict cycle}

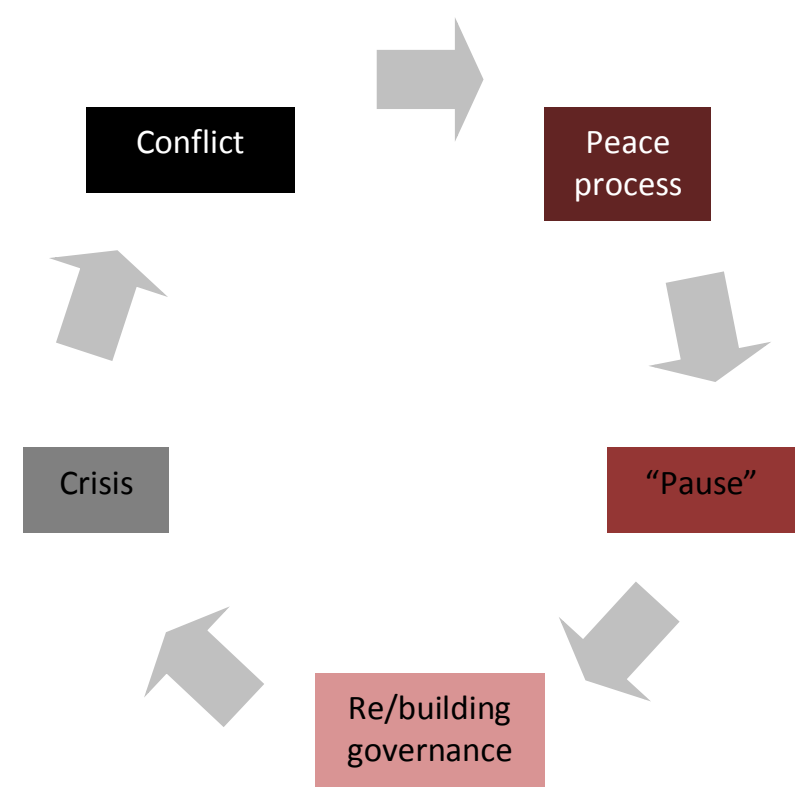

Every outbreak of violence threatened and sometimes drastically reversed, peacebuilding. Breaking the cycle, or at least slowing its pace to try to give time for "stabilisers" to work, thus emerged as a major challenge for all concerned.

Post-Cold War, the world appeared well equipped and ready to help peoples meet the challenges. As the threat of global nuclear war rapidly declined, it seemed that the international community would be able to work collectively and effectively in the cause of peace and the protection of human dignity in other trouble spots. The United States of America (USA) emerged as the sole superpower, with resources and commitment to peace and "freedom". The UN looked as if it was ready and able to play the full role

\footnotetext{
3 Fighting in the mind is a term used to indicate that notwithstanding a peace process, the combatants/contestants still see winning at any cost as the objective but use apparently peaceful processes (like elections and constitutions) as tools until they no longer deliver dominance, when they are abandoned for violence again. Thus, they have not mentally and genuinely abandoned violence as a key tool in political competition. This concept is encountered throughout this thesis from different angles.
} 
intended in its Charter, apparently unshackled from the Security Council veto threats of Russia (and, to a lesser extent, China). This was epitomised by Secretary-General Boutros Boutros-Ghali's (1992) famous Agenda for Peace. Also, the EU was emerging as a very significant regional, and potentially international, stabilising fund and force. International optimism had some foundation - examples of apparent initial success in international support included the apparent "ending" of the complex problems of Namibia (1990), Angola (2002), Cambodia (1993), South Africa (1994) and Bosnia and Herzegovina (BiH) (1995).

The record of failure, therefore, suggests that for these standardised external solutions to be effective, ongoing international presence (or even external administration) will be necessary to prevent the conditions of endemic conflict to supplant "peace". It seems unlikely that such an ongoing presence would be possible or even desirable in every instance of conflict settlement.

\section{LIBERAL-PEACE DRIVEN POST-CONFLICT STATE-BUILDING PRACTICES}

Since the end of the Cold War, the ideas associated with "liberal peace" theory have justified post-conflict peace-building. Briefly, liberal-peace efforts, despite variations, are grounded in the belief that sustainable peace is best provided for by liberal structures. Specifically these liberal structures require the adoption of democratically based government and the promotion of international trade. Together these are thought to "form the basis of international co-operation and consequently the end of war" (Richmond 2007: 27). According to the proponents of this approach, the proof is in the unique peacefulness of the groups of mainly western and developed states who have long-standing peaceful relations including low incidences of internal conflict (Diamond 1995; Doyle 1986; Paris 2004). The creation of a liberal state, therefore, is the peace-building strategy currently promoted in the western-led international political climate. Western nations, along with financial institutions (World Bank, International Monetary Fund (IMF)), international organisations (UN, European Union (EU), Organisation of American States, Organisation for Security and Cooperation in Europe, and UN Development Programme) and many Non-Governmental Organisations (NGOs) are guided by this unique peacefulness of liberally constituted states. The belief in the ability to "reform" people, institutions, states, 
and relationships is part of liberal peace theory's intellectual foundations (Mandelbaum 2002). In this regard, the liberal peace goes beyond simply ending violence by attempting to repair or create liberal structures that are assumed to support peace (Richmond and Franks 2009a). Peace, therefore, is promoted by interventions "delivering" democracy, international financial controls and requirements for open markets (Paris 1997: 56). Despite acceptance of the idea of "sovereignty with responsibility" at the international level (International Commission on Intervention and State Sovereignty 2001; United Nations 2004) and the imposition of liberal democratic policies and economies, at its core liberal peace theory is still essentially concerned with regulating and maintaining a statebased international system. The objective of the liberal peace is, after all, the creation of liberal states. The aforementioned institutions have consequently sought (and sometimes succeeded) to transplant the liberal-state apparatus's essence - often written down in documents (usually constitutions) - into many different historical and cultural contexts with the hope that it would work as predicted. The strategy was assumed to be easily reproducible, perhaps infinitely, even in smaller and smaller versions. In this thesis, such transplantation efforts are called reverse-engineering.

The liberal-peace theory is highly standardised: it supports intervention in the full gamut of post-conflict situations with the aim to introduce a reform recipe, which must be followed in a set order - demobilisation, constitution-making, legislation passing, registration of voters, elections (usually within two years of the "end" of violence"), funding of civil society, improving the capacity of the media and extensive state institution-building (Call and Cook 2003: 233; Ottaway 2003). The standard pattern has been remarked upon by observers of various peace-building endeavours, such as those in $\mathrm{BiH}$ and East Timor, which were remarkably similar despite the enormous differences in history, culture and development (Richmond and Franks 2009a). Further, the presence of international parties during peace negotiations has encouraged or indeed shaped democratic (and sometimes economic) liberalisation. Such practice is seen in the UN's role in mediating in post-conflict El Salvador; the drafting of the Namibian peace settlement by France, Canada, Germany, Britain and the USA; the UN Security Council's model for Cambodia which was adopted with minor alteration; or the Dayton Peace Agreement insisted upon by the international negotiators for Bosnia and Herzegovina $(\mathrm{BiH})$. Expert advisors have also played key roles in advancing the liberal peace project, 
for example through constitution drafting. ${ }^{4}$ In $\mathrm{BiH}$ and Somalia, constitutions have been entirely the work of outsiders but in many other societies a significant amount of foreign assistance has been given, such as in Iraq and East Timor (Dann and Al Ali 2006). International agencies like the IMF and the World Bank, as well as donor states, have also imposed conditions which require states to undertake specific economic and political reforms in exchange for aid. Thus, market-oriented reforms were imposed on $\mathrm{BiH}$, Cambodia, Croatia, El Salvador, Guatemala, Mozambique, Nicaragua, Rwanda and among others and in $\mathrm{BiH}$ political conditionalities such as compliance with international human rights standards were included (Paris 1997; S. Woodward 2002: 185). In some instances, internationals have even assumed particular governance roles, for instance on the board of central banks and in key governmental departments. In East Timor and Kosovo, international agencies have held very wide ranging roles, coming very close to a form of international trusteeship (Butler 2012; Chesterman 2002).$^{5}$

A common feature in liberal-peace-influenced peace-building post-Cold War is the prominence of one interpretation of "state". A $21^{\text {st }}$-century (or late $20^{\text {th }}$-century) state is one that is recognised and recognisable as such by the international community, functions like other states, makes decisions, upholds responsibilities, looks after its citizens, trades as an international entity under international law and does not conduct war, either against its own citizens, or against other states (and with heightened concern over terrorism, maintains internal security). In general, today's developed states have characteristics that, given human diversity, are actually remarkably uniform: rules, processes of decisionmaking, institutions, (executives, legislatures, courts, bureaucracies, police, armed forces), territories, peoples. This uniformity was undoubtedly a key part in producing the formulaic nature of liberal-peace peace-building.

\footnotetext{
${ }^{4}$ Other forms of assistance can be seen in the training of the media to be free or to strengthen local NGOs Krishna Kumar, 'International Assistance to Promote Independent Media in Transition and Post-Conflict Societies', Democratization, 13/4 (2006/08/01 2006), 652-67, Béatrice Pouligny, 'Civil Society and PostConflict Peacebuilding: Ambiguities of International Programmes Aimed at Building 'New' Societies ', Security Dialogue, 36/4 (2005), 495-510.

5 The concept of international trusteeship predates the establishment of the UN, when the League of Nations' mandate system saw selected states administer particular territories on behalf of the League Antony Anghie, 'Colonialism and the Birth of International Institutions: Sovereignty, Economy, and the Mandate System of the League of Nations; ' NYU Journal of International Law and Politics 34 (2001), 513633.
} 
In the face of the problems that emerged in places as diverse as Somalia and Cambodia in the early 1990s, the response of the proponents of the liberal peace has been to focus on better integration of, and efficacy in, the cornerstones of the theory - democratisation, the rule of law, human rights, markets, and neoliberal development (Richmond and Franks 2009b), rather than on a comprehensive questioning of the soundness of the theory for building sustainable peace or the method of delivery in practice (reverse-engineering). While the apparent peace in $\mathrm{BiH}$, East Timor or El Salvador may be lauded as "best practice" in western diplomatic capitals, chronic group mistrust, grievance and continued insecurity has led many to conclude that liberal-peace peace-building has failed to deliver appreciable benefits beyond an end to direct violence - at least in the short term (Chandler 2000, 2004; Paris 2001; Richmond 2005; Said 2002). Critics identify a number of problems with the nature and limits of liberal-peace informed post-conflict peacebuilding: ontological narrowness, questionable methodologies, the token attention given to locals - the actual "owners" of the peace, and questionable relevance to and legitimacy for, substantial groups of the population in post-conflict spaces (see for example: Boege et al. 2008; Mac Ginty 2008; Richmond 2009b; Roberts 2011). Advocates of the liberal peace agree on the failure, but the result has been attempts to make it work better (Chesterman 2004a; Paris 2010). Its underlying assumptions still represent the core thinking behind most post-conflict international operations today (see for example the August 2011 UN plan for post-Gaddifi Libya: Martin 2011).

Liberal democracy flourished in the $20^{\text {th }}$ century because states saw evolving political ties, trade relationships and mutual avoidance of war as beneficial and productive (Ramsbotham et al. 2011: 129-32). The liberal peace as broadly conceived is a massive achievement, or as Levy expressed: "comes as close as anything we have to an empirical law in international relations" (Levy 1988b: 662). However, as Rasmussen (2003) has convincingly argued, the liberal peace developed as "policy" not as a "fact" as the allied "victors" of World War II purposely embedded liberal principles in post-war societies and at the international level. Expansion of the liberal order came about because of perceived success of liberal democracy: "democratization tends to follow war... democratization decreases the systemic amount of war, and...the substantive and pacific impact of democracy on war increases over time” (S. M. Mitchell et al. 1999: 771). 
The international community will continue to intervene in post-conflict efforts to build peace because abandoning tens of millions of people is incompatible with the "responsibility to protect" (see: International Commission on Intervention and State Sovereignty 2001). Few would argue against the efforts of liberal-peace peace-building or for outright prescriptions of non-inference regardless of the ineffective results (Paris 2010). International interventions have after all sometimes been successful in ending violence (Doyle and Sambanis, 2006). However, the commonality of the resumption of violence - half of all intrastate conflicts resumed within five years (Report of the Secretary-General 2005b: 31) - calls into question the tenacity of the liberal peace. Accordingly, there may be merit in looking elsewhere for ideas and evidence to guide decisions and actions of those who seek post-conflict stability and to build peace, not simply just contain the violence.

\section{RESEARCH AIMS}

It requires little imagination to postulate that future governance arrangements must confront a conflict legacy that is centred on the relationships between people in society. The same people who were one or more of the combination of actors (combatants, abusers, victims, survivors, refugees, tribes, farmers, shopkeepers) are often the leaders of the next phases or the citizens who expect to vote, farm, produce, go to school, pay taxes and in myriad ways participate in the peace process and the rebuilding. In the push for liberalisation, it has recently been claimed that current post-conflict peace-building ignores the needs and interests of these very people and results in the maintenance of inequalities and conflicts, only including locals in the "technical moment of elections" (Roberts 2011: 411) or when full state sovereignty is returned (Chesterman 2007) ownership being equated with participation in the former or with authority in the latter. There is worth, therefore, in considering modifications to the understanding of liberalpeace theory and alternatives to current practices inspired by the liberal-peace ideas.

There is no coherent alternative in practice to liberal peace-building. However, promising alternatives may be built on the basis of theories and norms emerging under the umbrella of "conflict transformation". Briefly, conflict transformation holds that enduring peace requires that the underpinnings of actual or latent conflict must be transformed primarily 
internally through local learning, understanding, and change. Such a focus on people is overlooked when the aim is to reverse engineer a state in the liberal mould.

Rather than the fast-paced, top-down, ethnocentric approach characterising the liberal peace, the approach of conflict transformation seeks to transform conflict into something that is desired in a longer timeframe. It focuses not only on the content of the conflict but on the context and relationships between the actors involved. As Lederach (1995b: 212) explains, conflict transformation provides:

a new set of lenses through which we do not primarily "see" the setting and the people as the "problem" and the outside as the "answer". Rather, we understand the long-term goal of transformation as validating and building on people and resources within the setting.

Conflict transformation is therefore suited to post-conflict efforts as it is not driven by concerns to "solve" or "fix" undesired disputes but provides the ground to build something desired based on sufficient consensus, on learning and, most importantly, through the owners of peace with the international community in support.

The research, therefore, aims to investigate the possibilities of the Leviathan pacifying through the learning processes of groupism, receptivity and constitutionalism rooted in an autochthonous understanding of the past and agreement for an imagined future. While the normative claim is strongly voiced in the conflict-transformation literature, as I have sketched it above, in practice is underdeveloped (H. Lerner 2011). For while the rhetoric of "local ownership" is increasingly used in the theory and practice of post-conflict peacebuilding (see recently: United Nations Development Programme 2012) it lacks substantive explanation and therefore implementation beyond a generalised commitment to "consultation" and "participation" (Donais 2009). As Hurwitz (2005: 349) explains:

[local ownership] is particularly useful, inasmuch as it expresses a rhetorical commitment to something that is so ill-defined and uncertain that it can be used very conveniently and flexibly by international actors, but also by those members of post-conflict societies that are ready to manipulate political processes for their own benefit.

Therefore, in the place of reverse-engineering peace, learned constitutionalism could provide for genuine conflict transformation. The aim of this thesis is to investigate the 
beginnings of the pacification process and the shape of the 'space' that might be needed for autochthonous solutions based on learning to emerge. It is only then that there is the opportunity of state making (or another governance arrangement - regional perhaps or substate $)^{6}$ as learned constitutionalism is more formally institutionalised in ways that work for the particular cultures, histories and peoples in question.

The goal of this thesis is therefore somewhat modest: an aspirational and practical objective of improving the chances of success, or the converse: reducing risks of failure. Despite the apparent practical solidity of a verb like "building", in context the term "postconflict peace-building" contains this very aspiration: envisaging a range of attempts, with a range of strategies, to re-establish (sometimes establish) stable, enduring, peaceful governance.

\section{MOVING FROM THE LIBERAL-PEACE APPROACH TO THE BUILDING BLOCKS OF PACIFYING LEVIATHAN}

At a very basic level, the pacification process where the Western world made peace with itself in the context of the threats and conditions of the times resulted in the liberal democratic state. Thus, we can detect an overlap between the liberal democratic state and the pacification processes described in this thesis although the processes will not be identical in every situation, nor should the liberal state be held aloft as an end-state of all human experience. The liberal peace, in its historical context, is a model of the Leviathan pacified and learned constitutionalism in particular. However, there are no inherently superior practices to be gleaned from the historical record. It is relevant to note that socalled "developed" states took centuries to fight themselves to a place where they were receptive to the learning that was needed to achieve reasonably stable mechanisms for managing competition. Some developing states/societies are still fighting or struggling to

\footnotetext{
${ }^{6}$ While the word "state" is often used to refer to governance arrangements which may solidify post-conflict, it is recognised that there are valid alternatives to the nation-state model and a plethora of institutional design options which may be more appropriate. "In security and state terms, the world is bounded, static and divided into separate entities. In peace-building terms, the world is organic, social and very closely connected, so that problems in one area - particularly in the context of variations of the human needs and human security debates - constantly spill over" Oliver Richmond and Jason Franks, Liberal Peace Transitions: Between Statebuilding and Peacebuilding (Edinburgh University Press, 2009a) at 184.
} 
build sustainable peace. A lesson from the history of the west might be that the implementation of the liberal-peace model proceeded too quickly, and that there is a need to slow things down and use the space provided by the "pause" of the post-conflict period to allow peace to be valued, owned and understood - for the focus to be on learning, not some artificial "endpoint" for that learning.

Those emerging from civil war often have to co-exist in the short term, deferring controversial and potentially destabilizing decisions to some later date (as observed for example in Northern Ireland or Bougainville where internal group dynamics to be addressed first and status referenda scheduled for much later). Indeed when attention is pulled back from future institutional forms of governance to the immediacy of the "pause", the momentous challenge for the actual owners of the peace - the mass of individuals, leaders, ex-combatants, victims (including those in exile abroad) - is revealed. For while the particulars of learning and agreement will be unique to any society and on-going, in the immediacy of the post-conflict period the people must tire of violence, genuinely learn from their own histories and take responsibility in imagining their own future arrangements, having wrestled with their demons and addressed the issues that produced breakdowns in security, economies, politics and, ultimately, constitutions.

The search, therefore, is for new insights regarding the apparent relationship between past and future as it relates to forms of government. As noted above, it is logical to postulate that the collective of individual and societal experiences (varied, contradictory and shared) will in some way shape the decision-making processes in a state. Hence, if there is a violent past, where for the peoples/combatants concerned the conflict is only paused not ended, there is more likely to be a violent future. However, there is a better chance of a peaceful form of governance taking hold under certain circumstances, including if sufficient people have:

- tired of violence,

- become receptive to learning,

- learned the costs and

- adopted broadly-accepted alternatives for political competitiveness. 
Pacifying Leviathan is the term given to such transformations in this thesis. We do not yet adequately understand the factors necessary for these processes, many of which are autochthonous.

Clearly, the ambit for this extends beyond simply procedural solutions like "local participation" which has been the key addendum to the liberal peace in the wake of postCold War peace-building failures (United Nations Development Programme 2012). However, there are plenty of examples where participatory constitutional design processes did not have any measurable effect on the future of that society (i.e., Eritrea and Ethiopia) (Ginsburg et al. 2009: 215) or indeed the very activity resulted in further conflict (Congo-Brazzaville, Chad and Solomon Islands). Nor should the negotiation of a meaningful social contract, accompanied by a true mind-shift away from war, be confused with the mere process of writing (even the most expertly worded) constitutions and then holding referenda on them. Constitutions can embody a particular polity's own struggles and battles, document their own lessons and attempt to project forward with contextually appropriate guiding rules based on learning. However, on paper many postconflict constitutions follow a common set of core standards especially on human rights, democratic accountability to the people and peaceful conduct of political and other competition according to clear rules. Whether these rules reflect broad-based learning is another matter entirely.

Accepting the problems of defining "success" in terms of any transformation process, some factors of transformation (see: Lederach 2000; Väyrynen 1991) will be used to develop the social mechanisms or building blocks of this research, as explain below in the methodology section:

- Actor transformation: individuals' and groups' perception of conflict change; there is reorientation around positive governance and not just by elites, spoilers are sidelined;

- Rule transformation: broad-based learning reflected in new rules, including (but not limited to) constitutions;

- Issue transformation: the building of the governance processes through opening the agenda, changes in the cultural patterns of understanding and responding to conflict, rather than preserving elements of the conflict (e.g. by entrenching group division). 
With these kinds of transformations, it is possible that a society would have a better chance of building peace and be less at threat from a relapse of violent conflict.

Leviathan, as borrowed from Thomas Hobbes (1651), ${ }^{7}$ in this thesis refers to the collective decision-making processes and institutions that make up a state or other governance arrangement. Leviathan is shaped by the past and by ambitions for the future, framed in written and unwritten rules for governance. No transformation in human society is ever without contradictions. But in the conceptualisation of this thesis, when Leviathan is pacified, a critical mass of leadership will have renounced violence as part of governance. There may be outbreaks, remnants, die-hards, spoilers (like the Real IRA in Northern Ireland) - but when the balance has tipped, the odds improve that the experiences of protracted violence will transform into positive peace (Galtung 1975: 282$304 ; 1981$ ). This requires not just stopping immediate armed conflict (important as that step is), but sufficient consensus to reorient away from direct and indirect violence. In addition, the true acceptance and ownership of the rules and systems that emerge from genuine learning are crucial. The absence of overt violence does not mean that war is not continuing; it is simply less obvious - war by other means. ${ }^{8}$ In these situations, there are risks that the resources of immediate violence (guns) may be exchanged for other ways of continuing the fight, sometimes involving the resources of the state itself. Military opportunity is temporarily traded for political or economic opportunity, but the means can be reversed relatively simply if there is a will to war in the minds and strategies of key parties.

Three and a half centuries ago, Hobbes wrestled with the issues of his time: preserving peace, preventing civil conflict, formulating rules of power and government. He postulated a covenant that, although apparently a relationship between subjects and the

\footnotetext{
${ }^{7}$ This is not an argument in favour of the tough Hobbesian stance advocating absolute rule of the sovereign to combat the otherwise inevitable state of nature, which was influenced by Hobbes' experience of the 1640s English Civil War. Hobbes is seen as the founding father of modern political philosophy and the Leviathan has come to symbolise a broad concept of governance and was "tamed" by classical liberal scholars like Locke and Kant. Immanuel Kant, 'Kant: Political Writings', in Hans Reiss (ed.), (New York: Cambridge University Press, 1991a), John Locke, Two Treatises of Government (1824 edn.; London: Printed for C. and J. Rivington 1680-1690).

${ }^{8}$ As others have done, this is paraphrased from Carl Von Claueswitz's (1780-1831) dictum: "War is nothing but the continuation of policy by other means". Carl Von Clausewitz, On War (Vom Kriege), eds Michael Howard, Beatrice Heuser, and Peter Paret (1832 original edn., Oxford World Classic; London Oxford University Press, 1993) at 28.
} 
sovereign (the institutional embodiment of government), was better understood as a relationship among citizens who agree to the benefits of positive, peaceful governance and the rules that go with it (see Leviathan part II, chapter 18), because the alternative of constant warfare is far worse.

What tips the balance? How does "sufficient consensus" emerge? The documented histories of centuries of conflict-reform in Western Europe suggest that, over time, contradictions gradually sorted themselves out to produce something reasonably coherent and (mostly) less violent. The results are seen in widely-agreed (A. Brown 1999; Carothers 2004; Dahl 1971; Lipset 1959; Lipset and Lakin 2004) processes of governance, often set out in constitutions and other fundamental laws that deal with competition for power and resources, personal and social identity, religious belief, the relationships between people and power and the limits of force for particular objectives. In such states (and putting aside the variations of social welfare provisions):

- the state provides a framework for centralised regulation, tax collection and a monopoly on the legitimate use of force;

- democratic votes change governments and hence mediate political competition;

- the market mostly regulates economic competition;

- the rule of law provides trusted "referees" on the rules of the system;

- a strong conception that the state should not violate fundamental human dignity underpins the legal and moral authority of government;

- and, mostly, the people understand, implement and believe in the entire construction.

This liberal state pacification process whereby the Western world made peace with itself under its current threats and conditions is akin to the tiring, receptivity and learning discussed in this thesis. However the "developed" and "developing" nations' framework is significant, to the extent that developed states took centuries to fight themselves to receptivity to learning, resulting in reasonably stable mechanisms of managing competition; some developing states are still fighting - and it might, perhaps, be possible to learn quicker. 
This is not to suggest that the emerging products of every transformation will (or should) be a replica of the older democracies. That said, the process of transforming conflict is likely to demand familiar core ingredients, such as negotiation and willingness to compromise, and the establishment of clear rules, independently enforced. There are clear signs that local formulations of these ingredients can be embraced as "domestic" in statebuilding out of conflict (e.g., in South Africa, post-1994). As also noted earlier, however, there is unlikely to be orderly, linear progression. Some parts of society may keep fighting in the mind, or may be exhausted but unable or unwilling to learn and rebuild, or there may be more violence. There is also no irreversible reform. Voters may choose leaders and policies to advance sectarian interests, sometimes at risk of (indeed promising) violence. But if internal and external understandings are informed by the building blocks set out in this thesis, the odds might at least improve for more stable outcomes.

Determining "cause and effect" are notoriously problematic in explaining the realities of human activity. Throughout this thesis, I am critical of what I argue to be a prevailing theory, suggesting that it has contributed to the real-world failure in the sense that actual intervention and state-building is based on its ideas and premises. The logic is that poor theory misstates key problems and hence undermines the very peace it was engineered to buttress. Conversely, I argue that new research might assist the reconstitution of groups and governance after conflict. But how confident can anyone be that the previous theory caused current problems, or that the application of new theory will reduce those?

At least some of the answers lie in the persuasiveness of the logic and evidence thereafter, history and experience may provide what will no doubt still be contestable theses. For all the messiness of this field, the possible sequences can be represented diagrammatically in an adaptation of the conflict cycle set out above in Figure 1.

In the Learning Cycle in Figure 2, the violence in stage 2 (conflicting) will essentially drop out of the cycle if all the stages are properly completed. There will always be "problems" for any society and thus an ongoing need for the key phases of learning (the half moon) to address these. There is not a static or formulaic "end" state, for if lessons are forgotten the virtuous cycle may break down, and conflict may again enter the cycle. 


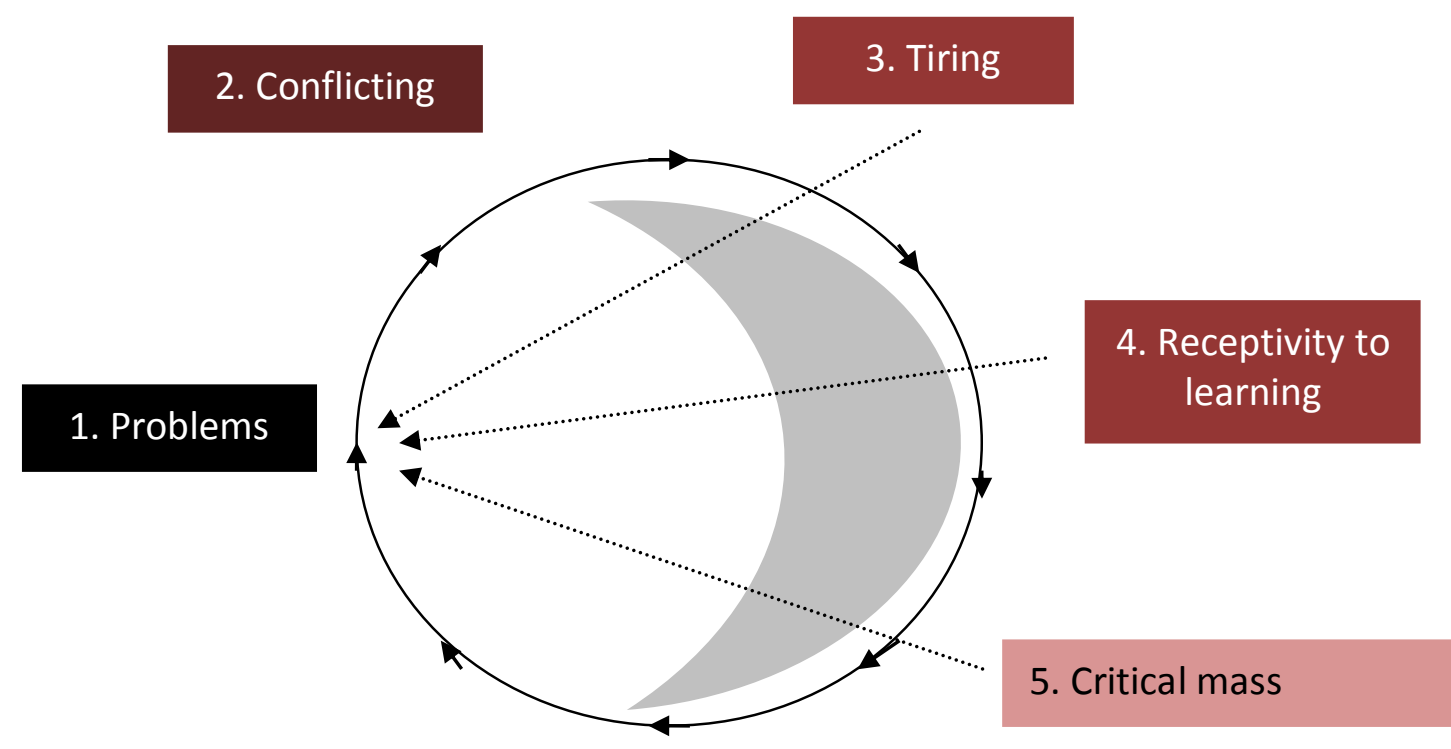

\section{Pacified}

\section{New systems/rules}

PACIFICATION / TRANSFORMATION

Pacifying Leviathan is at once theoretical and practical. The theory is significant, in the sense of hypotheses of why attempts might work or fail. The practicality involves the actual steps for the parties themselves, possibly with external support (e.g., the UN, EU, AU or other outside parties) to go around the cycle, in each phase, including operating the institutions of ongoing, stable governance.

Though examples are used throughout, most of this thesis concentrates on the theory. While some comments are made on practical issues for the future, detailed analysis of policy and implementation must await another thesis. In addition, the scope of conflict transformation and its underpinnings are vast. Many elements have been well-articulated in the literature and in practice, which are not necessary to repeat. The best example is the detailed literature and practice of the efforts to disarm, demobilise and reintegrate former combatants into civil society (known as DDR measures) (see for example: Knight 
and Ozerdem 2004; Muggah 2010; Stockholm International Peace Research Institute 2008). As the Romans found in antiquity (Flower 2004: 82-83), reconnecting former soldiers into civil life has always been a critical ingredient in peacetime. Hence, the current field of DDR is considered essential for the purposes of this thesis.

Another key, underpinning assumption is that pacifying Leviathan must recognise the role of gender. There is abundant evidence that women are the principal victims of armed conflict from killing, rape and other human rights abuses; and through displacement, disease, malnutrition, discrimination that produce such phenomena as honour murders, denial of property rights etc - and that women must be a critical part of any peace process, including governance (see for example: Moghadam 2005; Moser and Clark 2001; Sørensen 1998). Deeply-rooted patterns have to be addressed to pacify Leviathan, anywhere. Of course, women can be perpetrators of, and collaborators in, violence - as discussed in Chapter 4 on groupism. But just as this thesis does not focus on combat statebuilding or DDR mechanisms, so no attempt is made to recast the wealth of literature on gender/violence/peace-building, including the strategies to deal with access to justice, stigmatisation, and security sector reform (United Nations Division for the Advancement of Women of the Department of Economic and Social Affairs 2009). Along with many other issues of practical implementation, such issues fall into the "next steps" that must await further writing.

The core arguments of this thesis can, therefore, be summarised simply:

- Pacifying Leviathan requires rethinking some of the core ingredients of theory and practice in state-building out of conflict.

- Much of state-building after conflict in the post-Cold War period reflected particular theory and practice which, essentially, tried to transplant the liberal state apparatus of state government, expecting it to reverse-engineer peace and order, from the top down, in conflict societies. The most recent focus on rapid (re)construction of armies and the security apparatus is an addition to, not a contradiction of, this theory and practice.

- Although reverse-engineering was the obvious (and often only) option on the table, its premises failed to take account of the fundamentals relating to what people learn if there is protracted violence, what pacifying options might be 
available, and how the risks of repeated violence and winner-takes-all politics might be reduced.

- Whatever the exact causes, the results of most state-building after conflict in the period under particular focus (post-1990), had been (at best) a very limited success, measured by the yardstick of the establishment of positive peace before the international community somewhat disengaged.

This thesis, therefore, elaborates a combination of three basic elements as part of a reconsideration of the fundamental issues involved:

- groupism: the importance of groups in human conflict;

- receptivity: the often overwhelming cost of protracted conflict and the mind shift away from continued violence; and

- learned constitutionalism: the mechanisms by which the mass of individual and social experience might produce genuine learning in the form of rules and systems that are shared, obeyed, and valued (not formalities, ridiculed in their breach, whilst war by other means is continued).

- External support/intervention has a critical role to play in state-building out of conflict. The role will vary, depending on numerous factors, including geopolitics, funding and local consent. The key is to reconceptualise the roles, informed by the theory above and by the results of current practices.

- The arguments and insights proposed are supported by case studies in each of the key areas, resulting in a simple hypothesis: pacifying Leviathan requires going back to basics to inform better the field of state-building out of conflict.

The general conceptions should also not imply that there has been no adjustment or learning from practitioners, academics, diplomats, aid agencies and indeed the peoples of various conflict states in attempt after attempt at post-conflict peace-building, especially in the twenty years 1990-2010. In this busy area of international relations, aid, governance, and (mostly) domestic conflict, despite the prevalence of the formula- state model, inevitably this field is developing quickly. The UN (e.g. the Peacekeeping Best Practices Section (PBPS)) and others' approaches have been changing, reacting, backtracking, searching for new "lessons learned" (see: Barnett 2006; Fukuyama 2005b, backtracking from his "end of history" thesis; Roeder and Rothchild 2005, which 
encompasses a number of conflicting perspectives). At the heart of this research is an attempt to contribute to that endeavour. As noted, the goal is to assemble insights to inform the ambition of pacifying Leviathan.

\section{DEFINITIONS}

The term peace is, of course, highly contested. In the literature "peace" is located along a continuum - ranging from a simple emphasis on the absence of war (refer to first entry in Oxford English Dictionary: 1989: 398) perhaps as the result of a balance of power deterrence to the constructivist's positive peace (the absence of structural and cultural violence where positive human conditions are guaranteed) (Galtung 1975: 282-304; 1981). This thesis favours positive peace. In other words, peaceful states are ones which are not just lacking significant violence between citizens, but also where citizens are not dying due to war or to poverty, or where factors blind people to injustice or allow them to rationalise it. Boulding (1978: 3) agrees, identifying positive peace as: "a condition of good management, orderly resolution of conflict, harmony associated with mature relationships, gentleness and love". Peace is also assumed to be a continuous process, not a passive state (Montville 1987). Most importantly, peace must be relevant and legitimate - meaning that the state of peace must be appropriate and reflect the interests and preferences of the people. International support is not precluded, however, as positive peace takes place on a number of levels. Negative peace by way of contrast is simply the absence of direct violence and is often, colloquially, how peace is defined by governments. In such situations however slavery, apartheid, and other injustices could exist.

Conflict transformation, as noted by Miall (2004), draws on many of the familiar concepts of conflict resolution and rests upon the same tradition in theorising about conflict. What is useful about this framework is that it moves away from conflict resolution's normative solutions and emphasis on containment and control (the defacto dominant practice of the international community in so far reverse-engineering the liberal state has done little more than pause overt violence), and reverse-engineering, towards an evolving and holistic approach. If the purpose of peace-building out of conflict including intervention by outsiders is "peace" then transformation is crucial. If the strategy remains resolution and 
not transformation then efforts to build governance will continue with predictable problems.

As these components illustrate, a society on the road to positive peace requires not just the cessation of armed conflict and the minimum provisions of security but sufficient consensus to reorient away from direct and indirect violence. There may be outbreaks, remnants, die-hards, spoilers (like the Real IRA in Northern Ireland) - but when the balance has tipped, the odds improve that the experiences of protracted violence will transform into positive peace. The absence of overt violence does not mean that war is not continuing. In these situations, there are risks that the resources of immediate violence (guns) may be exchanged for other ways of continuing the fight, sometimes involving the resources of the state itself. Military opportunity is temporarily traded for political or economic opportunity, but the means can be reversed relatively simply if there is a will to war in the minds and strategies of key parties.

Post-conflict peace-building: Peace-building, peace-building or reconstruction are not clearly defined terms in literature or practice - influenced more by political, ideological and pragmatic preferences than by analytical clarity. Peace-building in this thesis is seen as processes by which a society attempts to move from a situation marked by earlier conflict to a situation in which the legacy of that conflict is no longer a defining feature. There are many possible fields which are integral to this because the interlocking issues are part political artisan (building), part political economy and philosophy (the state), part public policy (governance), part foreign/international policy (internationalism, aid, statecraft), part strategic studies (military/police), part psychology (ambition, anger, hurt, causes for fighting, recovery from violence), part anthropology/sociology (order and disorder in human societies), part history, part current commentary on pressing issues. The common phrase is "post-conflict peace-building" meaning, essentially, the attempt to construct stable, enduring, peaceful governance after such has been severely disrupted by violence. In the literature, these and related terms have significant complexities. The very words carry the notion that there has been serious politically-relevant violence on a scale that has damaged governing structures. "Post" connotes that the conflict has ended. This thesis explores the issues associated pacifying Leviathan in the "pause" - the period immediately after a peace "settlement" (peace agreement or comprehensive ceasefire) and before formal state-making. 
In any context, the word "conflict" might include violence on a spectrum from outright war to violence within communities. Peace-building discussions may occur across the spectrum of internal violence. For example where military action is raging at the same time that peace-building is underway (e.g. Afghanistan in 2010). Or there may be situations where the nature of conflict is not really state-related, in the sense that it is not significantly concerned with state governance and power (e.g. tribal rivalries in the Highlands of Papua New Guinea). The focus of this thesis is in situations away from the extremes i.e. where there has been significant and sustained political violence that has necessitated a peace process sequence to at least "pause" the most overt forms of armed violence. In that pause, the societies involved (often with international assistance) are hopefully attempting to transition from making war to building a government. Recent examples include Bougainville (as an autonomous province of Papua New Guinea) after 1997 and autonomy in 2005; and East Timor, after 1999, and independence in 2002.

\section{METHODOLOGY}

The concept of "reflexivity" is that it is important for writers to outline personal perspectives that shape their thinking - avoiding pretences of complete objectivity (Nightingale and Cromby 1999: 228). In this regard, the personal perspective I bring to this thesis is not "pacifist" as such, essentially arguing that violence is itself immoral under all conditions. Nor do I suggest that there are no ongoing problems of governance - or indeed forgetting the lessons of previous conflicts - in places where there is no substantial conflict. I do not see ending violence as a guarantee of human dignity and rights. That said my perspective (supported by much recent development literature) is that conflict significantly exacerbates the problems of governance and threatens the dignity of human beings everywhere. And in particular, I have been intrigued by the simple idea that whilst the evidence of human history is that violence has been universal, there are circumstances in which firstly people learn that violence is not appropriate, either in personal terms or in governance and are able to transform relations with each other and issues that were divisive through new rules for managing conflict in society. Hence my decision to investigation the beginnings of learning and transformation in the pause immediately following peace settlement - a crucial period which seems to have been 
glided over in the genuine but rushed "delivery" of the liberal peace. For while the literature is case studies rich and has many edited volumes on countries' conflicts, and specific aspects of transition, there is no attempt to squarely and systematically address the evidence on how the Leviathan is pacified during the pause of the postconflict period (or not as the case may be).

The work proceeds in several stages:

- A comprehensive literature review of the liberal peace, in theory, and as observed in a range of instances, with particular emphasis on the gap identified by the lack of attention to the owners of the peace.

- Defining the scope of the research through an exploration of the approach of conflict transformation and establishing an initial rendering of the building blocks that characterise pacifying Leviathan. This was done after a sustained period of reading and assessment of the complex multidisciplinary literature.

- Exploring the building blocks as described below and illustrated in an iterative fashion, assisted by a series of observations taken from a range of countries' experiences with paused-conflict governance

- Drawing some conclusions including on the implications for the role and manner of international assistance.

- Together with appropriate international assistance, the building blocks, given concrete and realistic shape, combine to form the framework of a new theory centring on the phenomena specific to paused-conflict governance.

\section{BIAS, LIMITATIONS AND CAVEATS}

Granted there is as yet no widely accepted alternative strategy to liberal peace-building in practice as described in this thesis. The ideas emerging under the umbrella of conflict transformation are essentially "untested".

This research does not seek to tell policy-makers (UN, donor states or others) what to do but provides the evidence of the investigation into the success and failure of pacifying Leviathan and learned constitutionalism. Many other issues potentially relate to post- 
conflict peace-building. However, it is not possible to account for them all. A number of different factors can be pinpointed in the literature (discussed in full in Chapter 2) as missing or crucial to the success of peace efforts. The thesis does not focus on future strategies of conflict-reduction - such as economic development to give people stakes in society - or discuss environmental obstacles. Security and stabilisation strategies such as the disarmament of combatants are already very thoroughly justified (Collier, 2007, 2009; Knight \& Ozerdem, 2004; Muggah, 2010, Stockholm International Peace Research Institute, 2008). Important as these might be for current and future policy and practice in peace-building, their full development is beyond the scope of this thesis. As Miall has observed (2004: 18) in relation to conflict transformation:

Any one practitioner or theorist can tackle only a part of this enormous field. All we can do is to undertake a piece of work in good faith and do it well... We plant seeds, and trust that interdependent co-origination will take care of the rest.

Despite the diagrammatic representation and the devotion of chapters to each, these building blocks should be thought of as a package, not a sequential progression. They are the basic ingredients in what might be termed a slow-cooking recipe: the longer, the better, but still dramatically shorter than the centuries and bloodshed it took Europe to pacify Leviathan. The ingredients will be illustrated through vignettes in country case studies. The focus is thus maintained on the building block (e.g. the way group dynamics operated in Rwanda) not each country's overall experience (e.g. the entire history of the Cambodian conflict). In other words, the method involves theory-building by the use of examples, not detailed, historical, case explanation as such. Nevertheless, where possible, the co-occurrence of building block aspects (or their combined absence) will also be drawn on. For example, it is possible to observe exhaustion but not learned constitutionalism. A successful outcome, it will be proposed, requires the whole package. Outside assistance may not always be needed. Failure would be a return to conflict or "negative peace" (no present conflict, but all the issues remaining essentially unaddressed, awaiting violence).

There are also positive and negative arguments to each of these building blocks. Where possible case studies have been selected to illustrate both sides; where the element of the theory exists and where it does not. 
The last sixty years have of course produced some examples of post-conflict peacebuilding regarded as successes by most writers, including West Germany and Japan following WWII and Costa Rica, and more recently, post-communist Poland (Chesterman et al. 2005; Dobbins 2003; Dobbins et al. 2005). One common feature of West Germany, Japan and Poland is their underlying and stabilising sense of national identity. In the case of Costa Rica, its relatively benign colonial legacy was one where political parties were encouraged, and give-and-take politics developed. Democratic elites pulled the country back from the civil war of 1948 by establishing a social compact based on an inclusive, liberal democracy, demilitarisation, a mixed economy, a welfare state and a strong sense of nationhood, thus avoiding the civil war and foreign intervention experienced by many of its neighbours in the 1980s (Morales-Gamboa and Baranyi 2005).

Other examples hold the potential for evolution from the dominant theory model to something akin to the learning for pacifying Leviathan deemed necessary in this thesis. Mozambique, for instance, is an example of exhaustion from war-weariness after a fifteen-year long civil war (1977-1992). There is peace - as in the absence of violence but it may be too soon to be sure of the durability of the new constitutional order (Cahen 2005). Northern Ireland is possibly transitioning from polarised power blocks to a willingness to work together, as discussed in detail in chapter 5. Hope exists in Kenya after the new Constitution of August 2010 was passed by referendum. The postindependence political "rules of the game" appear to have encouraged politicians to exploit tribal differences, evidenced in rising tension and violence, particularly around election time (see chapter 4). Though it is again too early to be sure, it may be that the dramatic violence that followed the 2007 election was a tipping point for learning as envisaged in Figure 2, evidenced by the new constitution. ${ }^{9}$

However, the vast majority of post-Cold War peace-building efforts are regarded much more equivocally. In addition - in places like Somalia, Zimbabwe, BiH, Cambodia - the

\footnotetext{
${ }^{9}$ The separation of powers in particular has been strengthened, as well as various checks on corruption and the devolution of power to often-marginalised regions. Full implementation of the constitution requires legislation to be passed over coming years. Issues will no doubt arise along the way as some political figures opposed the new constitution and the political class generally is notoriously self-serving. The Commonwealth has, however, promised legal expertise to work with Kenyan drafters on implementation, as a response to the Kenyan government's request for help. See: Walter Menya and Bernard Namuane, 'Commonwealth Offers Kenya Aid in Drafting New Laws', Saturday Nation, Tuesday 14 September 2010.
} 
building blocks of the theory proposed here are insufficiently present. In a few instances, South Africa and Bougainville in particular, conflict transformation has arguably occurred through processes that appear to resemble closely the building blocks set out in this thesis: understanding groupism, receptivity to positive peace and learning, and new, widely-accepted rules of governance.

For all the use of vignettes, I did not regard using detailed comparative case study analysis as appropriate for this research. There is always value to be extracted from comparisons, but the risk of extended concentration on some risked producing another formula state approach i.e. taking the end points of people's learning and recommending outcomes for implementation in other situations. Instead, principles and useful/not useful practices are extracted from a range of peace-building examples. Similarly, the technique of complex statistical analyses of conflict has been avoided, as this tends to leave people out and to look for lessons from mass statistics (e.g. on whether third party mediation helped or hindered the ending of conflict). As Ann Betts Fetherston (2000: 194) warns, such attempts even in the context of peacekeeping: "do not reflect the complexity and diversity or the cultures of violence of the social spaces within which these operations take place."

Instead the story of what is termed paused-conflict governance is investigated. This necessitates identifying the conflict transformation mechanisms in formal terms but also in operation. For example, one would expect to find concessions and initiatives in peace agreements but also in the language and actions of officials talking about things like "common citizenship" and "shared responsibility", in the rhetoric of leaders on their country's national day and in the behaviour of citizens and in the recognition that violent warfare is no longer appropriate, that fair representation is available in government as a means of being heard and to give visibility to shared decision-making. Obviously there are problems involved in making an assessment of international assistance which should ideally rest upon local voices. However, it is possible to present the research that examines how actors understand their achievements and assess this on the basis of the other building blocks. 


\section{OVERVIEW OF CHAPTERS}

The arguments of this thesis unfold in the following way:

As we have seen, Chapter 1 provides an introduction to this research including a summary of the core arguments and the methodology. Key terms and concepts are defined.

Chapter 2 focuses specifically on justifying the focus of this research through a review of the liberal peace-building theory, UN strategy and critique. It develops the big themes: the evolution of thinking behind the addition of peace-building into the UN's ambit and the prevalence of liberal peace both in theory and practice. The optimism and hope which characterised the post-Cold War period, however, has mostly failed to materialise in the successful transformation of conflict. Finally, a gap is identified to which my research seeks to contribute.

Chapter 3 returns to basics, explaining the conflict-transformation scholarly framework directing this research and the choice to favour this approach as a necessary redirection of conflict resolution and management.

Chapter 4 addresses the first block of theory - groupism. Explanations for human nature (violence) are explored, favouring neither "killer ape" nor "noble savage" views. A middle ground - that humans are capable of inconceivable violence and genetic aggressiveness but also incredible sociability and cooperativeness is preferred. Next the salience of group identity in conflict is addressed, critiquing the myth of ancient hatreds and explaining how ordinary men and women get caught up in violence due to the excessive focus on one element of their identity, shaped by collective fears, human needs and leadership exhortation. Understanding group behaviour and dynamics set the scene for the next three chapters, as the building blocks of this theory attempt to moderate "negative identity" and work towards constituting groups within the state to transform conflict into mediated competition.

Chapter 5 builds on the understanding of groupism, outlining exhaustion with conflict and receptivity to positive peace. Receptivity is clearly differentiated from ripeness and mutually hurting stalemates which are part of the mediation toolkit and concerned with 
getting a peace deal. In practice, exhaustion with violence has often been mistakenly identified (in its negative form) as making conditions ripe for settlement, thus allowing war by other means to continue and spoilers to flourish. Receptivity occurs at different rates in different groups or parts of groups. Where those that are truly peace-minded exceed those that are simply too aggrieved to renounce violence (or indeed benefit from the continuation of conflict), a platform is created for the renegotiation of the rules of governance based on agreed learning - the theory of the next chapter.

Chapter 6 addresses the point in which learning takes root in new rules of governance. Learned constitutionalism is the idea that there must be clearly articulated lessons, based on historical experience for the generation of new rules of governance. This learning must be owned by as many people in society as possible and formalised for it to cement and for the Leviathan to be truly pacified.

Chapter 7 explores ways in which international assistance can be employed to assist the three building blocks of this theory and perhaps assist in short cutting the historical progression of the conflicting state transforming. Outside pressure and oversight by international referees to buttress receptivity, hold groups together and provide space for learning to is explored.

Chapter 8 summarises the key arguments and conclusions of this research. Although outside the scope of this thesis, the implications for the current field of scholarship and practice of the theory developed in this research are introduced. 


\section{2: The current dominant strategy of liberal peace-building}

\section{INTRODUCTION}

Reverse engineering the liberal state is broadly the idea and practice of peace through liberalisation. In the previous chapter, the overall focus of this thesis stemming from some described flaws in liberal peace-building theory and practice was introduced. This chapter focuses specifically on justifying the focus through a review of liberal peace-building theory, UN strategy and critique. First I review liberal peace-building's origins in Enlightenment and particularly Kantian theory. Next I examine the ideological ascendency of the liberal internationalism in the $20^{\text {th }}$ century and the belief in actively constructing peace through liberal peace-building. Then I examine the manifestation (or persuasiveness) of this dominant view in the development of liberal peace-building at the UN and its focus on technical and institutional reform. This includes the UN's own assessment of practice and lessons learned. Next I cover the critical literature from the point of view of those who seek to refine the practice of liberal peace-building, those who believe it needs balancing by a primary focus on local context and people, and those who think it is fundamentally flawed and damaging before summarising the specific literature as it pertains to learning. I end this chapter with brief comments on the emerging themes and dilemmas highlighted in the UN and critical literature, thereby identifying a gap to which my research contributes.

\section{ENLIGHTENMENT ORIGINS OF THE LIBERAL PEACE}

Liberal peace theory derives from the political philosophy of the Enlightenment period (Hobbes 1651; Kant 1991a; Locke 1680-1690; Rousseau 1754; 1762, among others). The foundational elements of "liberalism" surround the core principle of individual freedom as defined here by Gray (1995: xii): 
[Liberalism is] individualist, in that it asserts the moral primacy of the person against the claims of any social collectivity; egalitarian, inasmuch as it confers to all men the same moral status...; universalist, affirming the moral unity of the human species and according a secondary importance to specific historical associations and cultural forms; and meliorist in its affirmation of the corrigibility and improvability of all social institutions and political arrangements

Liberalism's egalitarian and universalist outlook renders warfare irrational for it assumes that liberals will deal with conflict in peaceful ways (Doyle 1986; Schumpeter 1950). Liberalism's distinctive political modus operandi is well-equipped to manage conflict. A premium is placed on negotiation and compromise, pluralism and diversity are recognised, positive contestation and competition based on agreed rules are encouraged and peaceful critique, protests and demonstrations are accepted. Liberalism is a political vision to realise and sustain fundamental human values. Liberal principles and institutions, therefore, have pacifying effects. Democracy and capitalism, for example, promote peaceful competition so that even the "losers" are able to maintain a "sense of justice and trust in the system required for peace to prosper" (Lidén 2006: 21-22; Schumpeter 1955: 68).

Emblematic of the liberal peace on a grand scale is Kant's Perpetual Peace (1991a: 93115). He posited a correlation between the "republican" constitution of states and their relatively peaceful behaviour. Kant outlined three "definitive articles" inextricably linked in the quest for peace and rooted in the domestic, international and cosmopolitan spheres. The first article emphasised civil liberties, the rule of law and legal equality, as well as the separation of powers and representative government through republican constitutions (Kant 1991a: 99). The people's will or "spirit" is favoured over the specifics of representative governmental forms and procedures (1991a: 101). Today's liberal democracies (defined as those where liberalism is the dominant ideology, where the state exemplifies liberal ideas and where its citizens have leverage over decisions to go to war) have been interpreted as consistent within this definition (Danilovic and Clare 2007). ${ }^{10}$ Teson agrees that the modern conception of Kant's republics is a liberal democracy - that

\footnotetext{
${ }^{10}$ Kant believed in a very strict form of the separation of powers and therefore criticised classical Grecian direct democracy. He may also takes issue with certain elements of Western states' current democratic models but most modern representative democracy is very much in the vein of his republicanism Kant, 'Kant: Political Writings', at 101.
} 
being one where the form of political organisation guarantees full respect for human rights. However at a minimum level, Teson explains Kant's republicanism would be a government where political power is restricted by constitutional documents which prevent despotism (Teson 1998: 3).

Like Locke, Kant believed people to be equal despite diverse goals, cultures and beliefs. People are also rational - able to appreciate the moral equality of others and treat them accordingly - and share a fundamental interest in self-preservation and material wellbeing (Kant 1991b; Locke 1680-1690 chap 9, para 124). The Kantian state, therefore, solves the problem of governing individualised equals through maximising civil liberties for all - whether they are "rational devils" (those who comply with the just law with selfish or wicked motives) or the ethical agents he argues we should become (Doyle 1986: 1162). Republican constitutions, Kant argues, tame aggressive interests and provide a liberal caution to entering war. Legislative authority comes from the people and not from executive power. The legitimacy of governance, therefore, holds when "law itself rules and depends on no particular person" (Kant 1996b: 480-81). Republics are driven by the rule of law in their domestic governance and hold shared norms meaning that citizens of other states are recognised as morally autonomous individuals. This underpins a condition of mutual trust.

In the second of Kant's definitive articles - termed pacific union by Russett and Oneal (2001) - Kant (1991a: 105) theorises that "the rights of nations shall be founded on a federation of free states". Through this body liberal ideas and individual rights would be encouraged internationally. Instead of war, disputes between states would be settled by soft power and the rule of law common to all. To protect, peace and security Kant envisaged that such a union would gradually extend "to encompass all states...thus leading to perpetual peace" (1991a: 104).

Further peace would be served by "cosmopolitan law limited to conditions of universal hospitality" (Kant 1991a: 105). In the final article Kant adds material incentives to the two moral commitments. Universal hospitality concerns the liberal belief that all persons are free and should not be treated as enemies. World citizens, therefore, would have legal rights under a global order to travel, trade and share ideas (Habermas 1997: 105; Kant 
1991a). Economic interdependence, in particular, would motivate states to promote peace and avoid war.

From these theoretical underpinnings, a number of liberal propositions are revealed: the notions of separate peace, liberal pacifism and domestic peace. Firstly, liberal states are less likely to start a conflict with other liberal states than with illiberal states (Kant 1991a: 96). Secondly, liberal states are also less likely to initiate conflict in contrast to illiberal states. And finally, liberal states are less likely to experience internal violence than illiberal states.

In the final proposition, the late $20^{\text {th }}$-century focus on intra-state war saw Kant's thesis extended to democratic politics (Bellamy and Williams 2010; Rawls 1999: 23). Kant believed in gradual progress towards an ideal state of peace and commercial interaction which would occur as part of the natural course of development. Kantian scholars also infer from his writings $(1979,1991 b, 1996 b, 1996 a)$ that civil violence is less likely within democracies than in places which do not protect individual rights and liberties. While Kant conceded that revolutionary practices may facilitate progress and express the will of the people, he favoured gradual non-violent processes of domestic reform (E. Ellis 2005: 33-34; Kant 1979: 165,67). Citizens in free republics would also be reluctant to use force to pursue their own means even domestically. Kant emphasised the self-contradictory nature of rebelling against the government (Kant: 463). Instead as Habermas (1997) argues the public sphere the right of citizens to express their views and criticism is championed

Kant's definitive articles form a triumvirate. Pacific union and cosmopolitan law are requirements of the liberal peace. However, they are ultimately reliant upon and indeed generated by the presence and diffusion of republican states. Thus the first article effects of others, highlighting the importance of thoroughly understanding Kant's reasoning behind domestic sources of the liberal peace. Kant's liberal peace also implies an idea of positive peace as defined in the previous chapter, with its emphasis on liberal standards of justice.

Democracy, trade and cosmopolitan values based on individualism developed directly from Kantian theory. Richmond (2006) terms this the "constitutional peace". The liberal 
peace conceptualisation is also comprised of at least three other strands of Enlightenment discourse. In addition to the "constitutional peace", the "institutional peace", "victor's peace", and "civil peace" have evolved over centuries in Western imagination and emerged from debates in international theory and different historical contexts (Oliver Richmond 2006: 294). The "institutional peace" is grounded upon idealist, liberal internationalist attempts to bind political entities by agreement within normative and legal arrangements which regulate behaviour - from the Treaty of Westphalia to the establishment of the UN and beyond. The constitutional and institutional peace have clashed with the realist "victor's peace" which rests on military victory and domination, being influenced in the $20^{\text {th }}$-century by Europe's WWII experience with fascism. Lastly - the civil peace - emphasises participation, human rights and civil society as conditions for peace (see also: Richmond and Franks 2009b: 5-6). The latter represents the liberal peace's emancipatory possibility but is conceived around the individual, property rights and the market. In the next section, attention turns to the legacy of the "institutional peace" in the rise of liberal internationalism in the $20^{\text {th }}$ century before addressing how this theory has directly shaped the development of liberal peace-building at the UN.

\section{THE ASCENDENCY OF LIBERAL INTERNATIONALISM IN THE $20^{\text {TH }}$ CENTURY AND THE SEARCH FOR STATE MODELS FOR PEACE}

Liberal internationalism at its most basic level combines liberal beliefs with “internationalism" - defined by McGrew (2002: 286) as concern for "the promotion of transnational or global solidarity and international governance". Therefore democracy, international economic integration and international governance are, together, seen as creating the conditions for the realisation of the perpetual peace (Doyle 1997; Russett and Oneal 2001). The challenge for liberal internationalism in the $20^{\text {th }}$ century was to find a theoretical model through which to create the perpetual peace which eventually took the form of liberal peace-building.

\section{i) Early $20^{\text {th }}$-century liberal internationalism}

Liberal internationalism evolved throughout the $20^{\text {th }}$-century experience. In the early decades, the concern was state independence and building an international legal order to 
reinforce state sovereignty and non-intervention. Following WWI liberal thinkers saw the need to construct peace through what Woof called "consciously devised machinery" (1916: 127). Woodrow Wilson was perhaps the first statesman to adopt the liberal peace thesis (Paris 2004). He called for the regulation of the international system to deal with disputes and global force capable of mobilisation if conflict resolution failed. Open trade, national self-determination and progressive international change were part of this world view. While Wilson believed that a stable and peaceful international order was to be built around liberal democratic states, he acknowledged that the architecture of a liberal order needed to be universal and open in scope and membership. Such thinking provided the foundation for the League of Nations - created to promote cooperation, peace and security. The devastation of WWII a mere two decades later renewed the emphasis on open trade and cooperation between states. The UN was created to resolve conflict through negotiation and agreement. The international order that evolved in subsequent decades was Western-centred embodying the hallmarks of liberal internationalism openness, state sovereignty, rule-based relations and institutionalised in the UN and other multilateral organisations. Western states have dominated the development of the international system since the 1800 s and formed the basis of most theories of international relations in general and of peace and security in particular (Chan 2010). In the context of a weakened Europe and the powerful Soviet Union, the USA assumed responsibility for organising and operating the system and the liberal hegemonic order took shape. The American systems of currency, technology, markets and alliances became fused into the wider liberal order.

\section{ii) Search for state models to deal with conflict}

In the Post-WWII context, liberal efforts to construct peace through state models began in earnest. Decolonisation afforded an opportunity for political and economic liberties to spread. Rothermund's (2006) comprehensive history of decolonisation shows that the rapid change in world views on colonisation, along with the demands of the colonised people and their leaders and the UN's rush for independence were unstoppable (often armed) tides. The pace of decolonisation processes in places like Uganda, Somalia and the Congo meant the legacy of colonisation was "thin administration" that did not have a chance to cement governance. Decolonisation, particularly in much of Africa, was less concerned with capacity or the development of individual colonies to meet the European 
definition of statehood, than a rapid change in international views on the legitimacy of colonialism and self-determination. Colonial administrations in these countries had not only mostly failed to foster an indigenous experience of liberal government, but they were also comparatively "thin" in infrastructural terms while being paradoxically strongly authoritarian (R. H. Jackson 1987; Kirk-Greene 1980). The internal apparatus, political system and political economy were designed to protect the interests of foreign actors and, therefore, alien to the administered society. Only occasionally were local elites involved; such as the favoured Tutsi in Rwanda, the Kikuyu in Kenya and Hawiye in Somalia.

The independent state models that surfaced at first appeared to provide citizens with the best opportunity for better living standards. However as Jackson (1987, 1990; 2004a) explains many were "quasi-states" because while they had juridical statehood they lacked "empirical statehood". The resulting collapse of the post-colonial state experience (some post-Cold War) in many third-world countries and the associated violence and hardship for citizens saw the emergence of further theory explaining the failure. On the one hand, theory originating in the West took responsibility for a development model for thirdworld countries under the auspices of the democratic and capitalist world (Rostow 1971). Modernisation theory in the 1950s and 1960s, for example, espoused a belief in the natural evolution of "backward" economies towards self-perpetuating market democracy (D. Lerner 1958; Lipset 1959; Rowstow 1960). This was later dismissed as inherently flawed (Brugger and Hannan 1983; Roxborough 1988). Law and development literature in the 1960s upheld the raison d'être that law matters in development - law being a malleable and manipulative instrument to promote economic development, democracy and human rights (see Douglas 1962; Seidman 1972). This, too, quickly fell out of favour even amongst previous proponents (see Gardener 1980; Merryman 1977; Trubek and Galanter 1974) because local cultural variations were overlooked (Friedman 1969: 28). Trubek and Galanter (1974: 1080) concluded that such efforts in social engineering deepened inequality, curbed participation, restricted individual freedom, and hampered efforts to increase material well-being.

The USA, buoyed by success in rebuilding post-war Japan and Germany, turned to nationbuilding theories of national integration and consolidation to modernise the fragile states of Latin America, Africa and Asia. Koonings and Krujit (2002) explain such endeavours as the attempt to construct both the physical infrastructure and institutions of an effective 
state while simultaneously seeking to instil a sense of national identity within local populations. Latin America of the 1960s was one of the first laboratories of the liberal peace. The US attempted to modernise their economies, believing that liberal political outcomes would follow (Carothers 1999; Packenham 1973: 70; Rostow 1971: 70). The claimed universal validity of the western state model saw elites supported by democratically elected governments. Latin America illustrates that while government favouring capitalism usually followed, democracy did not (Jahn 2007: 102; P. H. Smith 1999: 150-52). This led Huntington (1968) to argue that economic progress in underdeveloped countries did not lead to democratization but was in fact often destabilising and conducive to the rise of authoritarianism

Against this liberal search for state models, a neo-Marxist critical discourse arose explaining underdevelopment at the periphery as exploitation through the capitalist centre (Frank 1966; Wallerstein 1976, 1984). Post-development theorists reject ethnocentric solutions privileging instead the local, the grassroots and traditional knowledge (Escobar 1995). This theory is criticised for reducing local actors to "pawns" of outside forces (T. Smith 1979). In terms of the ascendancy of the liberal internationalism - the turning point of which will be addressed next - Third World Approaches to International Law deconstruct the impact of international law on colonised peoples and seeks to eradicate the conditions of underdevelopment in the developing world (see Bedjaoui 1979; Kennedy 1988; Mutua 2000). These scholars reject international law as a racialised hierarchy of international norms and institutions that play into the power dynamic between first- and third-world (subordinate) peoples. This scholarship warns against the harm Western powers and institutions (IMF, World Bank) can do, albeit unintentionally. However, it has failed to articulate an alternative global legal regime (Attar and Miller 2010) and does not provide a theoretical framework for tackling conflicts or building governance internally.

Instead what emerged at the end of the $20^{\text {th }}$ century was the ascendancy of liberal internationalism and the revival of Kant's separate peace in the emergence of liberal peace dominating international relations ideology and thus policy. 


\section{iii) Liberal internationalism ascended}

Throughout the $20^{\text {th }}$-century liberal-peace theory gained traction and a liberal hegemonic order eventually developed. However, the Cold War standoff prevented any global preference for domestic state institutions. This all changed as the Cold War ended. Such was the optimism in the superiority of liberal internationalist ideals that the liberal peace was offered as the solution to a range of societal problems - particularly civil violence (see for example: Diamond 1995; Levy 1988a; Muravchik 1996; Oneal and Russett 1997, 1999). The fall of the wall thus became an "interregnum moment", in the same vein as the conclusion of both world wars, despite being what Heathershaw calls a "reductive and teleological informed reading" of that event (2008: 600).

The 1990s "third wave" of democratisation caused "tremendous optimism" in the likelihood of further consolidation and expansion of liberal states (Fukuyama 2005a: 84). Indeed the total number of democracies increased by nearly half from 1990 to 2003, not least because of what Danner (2009: xxi) calls the "... great telegenic festival of freedom" in the East, matching the sharp decline in civil conflicts over the same period. With the invasion of Iraq and subsequent attempts to rapidly democratise that country, it was thought the entire Middle East would "flip" turning it into a "crescent of shining, prosperous democracy" (Etzioni 2007: 38; see also Muravchik 2002).

Those scholars who contributed to the Kantian revival at the end of the $20^{\text {th }}$ century believe that in the present day there is a promise that war will fade, and realist principles will be finally superseded. Russett warned in 1995 that the "edifice of realism will collapse if attributes of states' political systems are shown to have a major influence on which states do or do not fight each other" (Russett et al. 1995: 164). Indeed strong empirical and theoretical evidence shows that liberal states do exercise restraint, and separate peace exists between liberal states (Doyle 1983; Lake 1992; Rummel 1997; Solomon 2003; Weart 1998). Empirically this is confirmed by Huntington's (1993) study of the expansion of democracy and Weart's (1998) examination of every recorded conflict between democracies since the beginning of dēmokratia in the ancient city-state of Athens. Explanatory factors echoing Kant's philosophy include the lack of inclination to wage war on nations where citizens hold the same basic ideals and principles, unfavourable public opinion, shared norms of compromise and cooperation, shared 
interests in international trade, powerful internal institutional checks and public opinion, and reinforced mutual respect and cooperation through membership of international organisations (Jacobs and Shapiro 1994; S. M. Mitchell et al. 1999; Owen 1994).

Where there have been wars between seemingly liberal states, these have been explained as a matter of perceiving one of the parties as less liberal than the other/s, i.e., Wilhelmine Germany in 1914 (Owen 1994). The fact that liberal states are perhaps no more peaceful in their interactions with states that are non-liberal than are states generally is where the liberal peace combines realist insights on the world outside the liberal zone of peace - the zone of war - or the "victor's peace" (Mearsheimer 1995; Richmond 2005). This is a choice "between preserving liberalism's material legacy of the current world order at the cost of liberal principles or of finding ways of adjusting to a changing world order that protects liberal principles" (Doyle 1983: 349).

Further, many studies support the internal peacefulness of liberal states (Hegre et al. 2001; Ray 1995; Rummel 1997; Russett et al. 1993). This is primarily attributed to democracy's guarantee of basic human rights and nonviolent avenues for the resolution of political disputes (Bellamy and Williams 2010: 23-24). Doyle expands on this, pointing to four institutional requirements: Citizens possess "juridical equality" and other fundamental civic rights (i.e., religious freedom and freedom of the press); representative legislatures derive authority from the electorate's consent and exercise authority free from restraint (including from other states); the economy protects the rights of private property which extends to the means of production; and the economy is shaped by supply and demand and a market free from strict control (Doyle 1997: 207). Legitimacy associated with democracy makes it difficult to mobilize arms against the prevailing order, reducing the likelihood of civil war (Owen 1994: 90).

The realist counter-perspective dismisses this "proof" as liberal fantasy arguing that permanent peace is not possible (Layne 1994; Mearsheimer 1990; Waltz 1993, 2002). The notion that internal processes and political structures within a state can play a role in shaping international behaviour is rejected. They also dispute the empirical evidence, countering with Finland's support for Nazi Germany - and the non-military overturning of democratically elected governments in Chile and the Dominican Republic by the US (Russett et al. 1995). Further, they point to the reclassification of democracies as 
"authoritarian" when they go to war (i.e., Germany pre- and post-WWI). Democracies, they argue, are simply too new to reveal any real patterns (Russett et al. 1995: 164-65; Waltz 2002). Waltz (2002: 31) further dismisses Kant's republics as too restrictive to ever be reality. When pushed to explain patterns of peaceful states Waltz and others revert to an argument against a casual relationship between democracy and peace favouring instead great power relations. The expansion of liberal states in this view would have little impact on international peace and security but may alter the power balance of states international which could endanger world peace (Mearsheimer 1995). Instead of the active construction of liberal states, partition along ethnic lines is seen as the solution for societies experiencing civil conflict (Kaufmann 1996).

While not dismissing the relevance of power plays in liberal democracies' foreign policies, the empirical evidence that liberal ideology and institutions have independent power over decisions on war has been overwhelmingly convincing (Owen 1994). It is, of course, possible that the two forces sometimes push in different directions, just as some actors in the world or domestic politics are liberals and some realists. However, as Levy (1988b: 662) concludes the democratic peace "comes as close as anything we have to an empirical law in international relations".

\section{iv) Liberal peace-building}

The consequence of the casual relationship between liberalism and peace pushed to the fore by the ascendancy of liberal internationalism are theoretical arguments for the active construction of peace through liberal peace-building. In his seminal work Kant, Liberal Legacies and Foreign Affairs Doyle (1983) is credited with reintroducing Kant's logic of the separate peace and providing important impetus for the revitalisation of liberal internationalism. He argued for a global structural environment whereby illiberal regimes made a choice between liberal reform and participation in the world market or collapse and civil war (Doyle 1999: 54-5). It was logical and rational to attempt to create the perpetual peace; he argued, as where policy-makers had been informed by Kantian principles they had been quite successful (Doyle 1986). When civil war occurs, therefore, the UN should intervene: 
...successful contemporary peacebuilding changes not merely behavior but, more importantly, it transforms identities and institutional context. More than reforming play in an old game, it changes the game (Doyle, 1999:55).

Here Doyle goes beyond Kantian theory which did not champion external force and also the liberal internationalist policy of the time, where the strategy employed to push liberalism was limited to structural and diplomatic instigation. Further, he argues that the community of liberal states must be protected from the wilderness of the "illiberal other" who threatens the growth of peace - for if not reformed then collapse would follow (Chesterman et al. 2005; Doyle 1983, 1997, 1999). Liberal peace-building, therefore, is a means of constructing liberal states in post-conflict contexts to expand the zone of peace (Doyle 1997). It can assist post-conflict peoples in realising the emancipatory political development that they would not otherwise have the resources or capacities to take part in, thus freeing individuals from their archaic societal constraints (ibid).

Liberal peace-building is assisted by the belief that liberalism is the highest possible point along the trajectory of historical progress (G. H. W. Bush 1990; Morris 2011). Political systems in the more established democracies are taken to display a "clear moral and practical superiority", with the associated high level of development, they provide the model all other states are expected to follow (Diamond 1996: 35; Paris 1997: 57). This idea is most famously pronounced in Fukuyama's (1992) declaration of the "end of history”. States that allow such full democratic domestic competition fall outside history and those who fail to allow it are regarded as still within history.

Liberal internationalism has therefore changed the logic of international legitimacy through the introduction of the ideals democratic self-determination, good governance and human rights promotion. As Clark concludes, although these have been important elements of the international society since the end of WWII, these ideals were not visualised as ends in themselves. Now, these elements are understood as the "means to the wider international purpose of security, order and peace" (I. Clark 2005: 188). This necessitated a move away from the notion of sovereign states and non-intervention to a post-Westphalian understanding of the separate peace requiring not only the international system to be liberalised but individual states as well for international peace to cement (Bellamy and Williams 2004b; R. H. Jackson 1990). 
This is fundamental change. The Westphalian system's rules of legal equality, noninterference in other state's territory, reciprocity and respect for religious and political diversity were preconditions for the evolution of the liberal state (Bellamy and Williams 2004b: 3; K. J. Holsti 1999: 284-86). Over the last few centuries, Westphalian sovereignty has been the single most universal and agreed-upon norm of international politics underlying international law, the UN system, and historical movements of anticolonialism and national self-determination (Krasner 2004, 2005). Globalisation however impacted upon the state in terms of increased interdependence and integration (N. Harris 1990; Ohmae 1993). The result is that a number of problems are now considered to be of international concern and causality including intra-state conflict. A more recent manifestation of this is the concern over global terrorism and failed, unstable or war-torn states pushed to the fore of foreign policy and international politics in a post-9/11 world. State weakness and the inability to enforce law and order domestically is identified as the most worrisome dangers to the international system (Gros 1996; Helman and Ratner 1993).

Mechanisms to "fix" these states have come to be viewed as central to maintain global order and to exercise them is equated with "responsible membership" of international society (Chandler 2006; Newman et al. 2009b). The UN placed the building of state institutions at the centre of post-conflict efforts in its 2005 review (Call 2005). Donors restructured their offices in response and the World Bank created the Fragile States Unit (Bensahel 2007). Rotberg (2005: 42) goes as far as to claim that peace-building has: "become one of the critical all-consuming strategic and moral imperatives of our terrorised time". The impact of the terrorist events of 11 September 2001 heightened the merging discourses of development and security in the language of non-governmental actors and militaries and defence ministries (see for example G. Bush 2002; Development Assistance Committee 1997, 2003; Leader and Colenso 2005; Solana 2003). Liberal peace-building now emphasises security and stabilisation (Duffield 2007) and "failure" has been used as justification for intervention (DFID 2006; USA 2002).

This is not to imply that peace-building in the liberal internationalist approach is an attempt to transform radically the very structure of global political and economic order. It is more temporary and limited then that - a means for universalising the Western liberal 
state and the liberal zone of peace and security (Gates et al. 2004). Ultimately this is a conservative enterprise in reaffirming the sovereign state system based on liberal premises, not about instigating supra-national projects of an international organization, reform and justice which is perhaps what President Wilson was envisaging (MacMillan 2004). Liberal internationalists do however have a bias against any alternative political system and as such the possible compromising of liberal principles in a post-conflict transition is the lesser evil.

Embracing liberal peace theory the dominant Western, and de facto international, view of peace-building is as a tool for the international community to use in assisting societies emerging out of conflict to stabilise by attempting to construct post-conflict societies in "liberalism's divine image". This is why peace-building is more commonly termed "liberal peace" in contemporary literature (Susanna Campbell et al. 2011; Lidén et al. 2009). The neo-liberal state model is championed as a new universal standard in order to replace out-dated models of governance with modern institutions (Paris 1997: 56). The framework's core components are liberal democratic political structures and processes (good governance, democratic multi-party elections, human rights, the rule of law, the development of a limited but functional state and the empowerment of an ethnocentric type of civil society) and liberal or neo-liberal economic practices (the privatisation of public enterprises, reduced state subsidies, the deregulation of capital markets and the lowering of barriers to international trade) (Bellamy 2008; Richmond 2008; Selby 2013).

In summary, the liberal internationalist theory of peace and peace-building that dominated at the end of the 20th century is a composite of liberal peace theory and liberal peacebuilding with elements of internationalism and contingent sovereignty and even some cosmopolitan elements. The liberal peace suggests a progressive and rational ontology and epistemology of peace which can be legitimately constructed for others.

The idea to consciously construct peace led to a methodological approach moving away from providing space for negotiated settlement to authorising the transferral of peace through the process of liberal peace-building. What followed was the comprehensive testing of this theory for those states emerging from conflict through UN peace-building policy and practice. 


\section{UNITED NATION'S PEACE-BUILDING: LIBERAL PEACE-BUILDING IN PRACTICE}

Liberal peace-building arose from recognition that UN strategy faced limitations with its traditional military-style (peace-keeping) measures in the context of post-Cold War intrastate conflict (Boutros-Ghali 1992, paras 11 \& 21). US-Soviet polarization meant that the $\mathrm{UN}$ had avoided domestic arrangements in its missions when no agreement on the nature of those arrangements could be agreed upon. In fact, Security Council vetoes had caused paralysis from all but minimal activity (Paris 2004: 15). However the ascendancy of liberal internationalism and globalisation became defining forces in the birth of the concept of peace-building at the UN, as the near universal collective security organisation (Paris 2004: 19). This section explains the next piece in what we now recognise as the liberal peace: how post-conflict peace-building evolved from a board ambit of potential post-conflict activities to a more specific view of state-craft and institutional reform. This was assisted by the idea of responsible international membership in the responsibility to protect. The UN's own assessment of its peace-building practice is then discussed supplemented with supporting literature - and brief comments on the need for further operational and policy reform in light of lessons learned.

\section{i) The beginnings of liberal peace-building at the UN}

Post-conflict peace-building developed from the then UN Secretary-General BoutrosGhali's attempts to centre the UN as a progressive autonomous agent of peace and global justice at the end of the Cold War. He sought to capture growing Western interest in actively trying to construct peace in societies struggling from conflict through progressive multilateral consensus (Sabaratnam 2011). And he grasped the opportunity to (BoutrosGhali 1992, para 3):

achieve the great objectives of the Charter - a United Nations capable of maintaining international peace and security, of securing justice and human rights and of promoting, in the words of the Charter, "social progress and better standards of life in larger freedom." 
Thus "post-conflict peace-building" was added to the UN vocabulary in his An Agenda for Peace ${ }^{11}$ - affirming the emerging paradigm of liberal internationalism.

Peace-building was initially defined broadly as: "rebuilding the institutions and infrastructures of nations torn by civil war and strife" (1992, para 15). Its aim was to: "identify and support structures which will tend to strengthen and solidify peace in order to avoid relapse into conflict" (1992, paras 5, 21). Boutros-Ghali argued for a generic interpretation of peace-building dealing with the full range of concerns involved in the transition from protracted violent conflict to stable peace. This required an understanding of conflicts that were based on structural violence and social grievance. The pragmatism of a broad potential spread of activities came explicitly aligned with the objectives of the liberal peace from inception. Economic development and political freedom were seen as the appropriate conflict remedies. Peace-building should advance political democracy, establish order, foster economic development, and improve human rights (para 55). Boutros-Ghali believed there was:

\footnotetext{
... an obvious connection between democratic practices - such as the rule of law and transparency in decision-making - and the achievement of true peace and security in any new and stable political order. These elements of good governance need to be promoted at all levels of international and national political communities (para 59).
}

The identified outcomes included institutions necessary to maintain (electoral) democratisation, human rights protection, the rule of law, a strong civil society and economic reform (Boutros-Ghali 1992 paras 32; Richmond and Franks 2009a: 3).

A major evolution occurred when peace-building became synonymous with reform of state and society. This is evident in the Supplement to the Agenda for Peace (BoutrosGhali 1995b) where Boutros-Ghali struggled with realistically addressing intra-state violence while continuing to address the injustices underlying conflict (1995b paras 13 \& 22). Instead of concluding that interventions were overambitious he persuaded others that where state institutions had been destroyed intervention had to evolve into a

\footnotetext{
11 The term appears to have been first coined by Galtung in his essay Three approaches to peace: peacekeeping, peacemaking and peacebuilding where he relates peace-building to reaching for positive peace by creating structures and institutions of peace based on justice, equity and cooperation, thereby permanently addressing underlying causes of conflict and preventing their turn into violence Johan Galtung, Peace, War and Defence - Essays in Peace Research (2; Copenhagen: Christian Eijlers, 1975) at 282-304.
} 
comprehensive reform agenda to build effective government (para 13). Boutros-Ghali also focused on development as a way to peace (1995a, para $3 \& 40$; Report of the Secretary-General 2005a). However, he cautioned that "only sustained efforts to resolve underlying socio-economic, cultural and humanitarian problems can place an achieved peace on a durable foundation" (para 22).

The reform agenda has tended to overshadow underlying issues. In 2000 UnderSecretary-General Lakhdar Brahimi aligned peace-building explicitly with the aims of liberalisation: "democratization and civil society building that includes effective civilian governance and a culture of respect for basic human rights" (Report of the SecretaryGeneral 2000, para 39). This mirrors liberal internationalism's active construction of peace through liberal peace-building: "force alone cannot create peace; it can only create the space in which peace may be built' (viii-ix). Three key peace-building objectives were outlined: consolidating internal and external security, strengthening political institutions and good governance, and promoting economic and social rehabilitation and transformation (Report of the Secretary-General 2001).

\section{ii) Re-definition of state sovereignty (or The Responsibility to Protect)}

How the UN would go about liberal peace-building, as discussed above, was previously constrained by the Westphalian state system. However as maintenance of international peace and security came to be viewed as dependent upon the liberalisation of states Secretary-General Kofi Annan (1999: 49-50) pushed for redefinition towards human rights notions of sovereignty:

States are now widely understood to be instruments at the service of their peoples, and not vice versa. At the same time individual sovereignty - by which I mean the fundamental freedom of each individual, enshrined in the charter of the UN and subsequent international treaties - had been enhanced by a renewed and spreading consciousness of individual rights. When we read the charter today, we are more than ever conscious that its aim is to protect human beings, not to protect those who abuse them.

In 2001, the UN's International Commission on Intervention and State Sovereignty was tasked with answering Annan's challenge. In making recommendations to the international community in its report The Responsibility to Protect, the commission 
followed Annan's lead in reframing sovereignty away from its associations with "control" and towards the idea of sovereignty as "responsibility". A new social contract in effect was proposed, expanding upon the one that should exist at the state level (amongst citizens and between citizens and the state), to one between states and the international community (para 1.35). When a state fails to protect its citizens, and peaceful measures are not working, it is now proposed that the international community should assist (Report of the Secretary-General's High-Level Panel on Threats Challenges and Change 2004; United Nations General Assembly 2005b) - not just react militarily, but prevent and rebuild (International Commission on Intervention and State Sovereignty 2001, para 2.29). This has been important development for the liberal peace as it meant it was longer at odds with the very notion of sovereignty. Instead, those favour of the liberal peace could now call for it to operate in the very name of sovereignty through post-Westphalian capacity building for democratic "self-determination" by means of direct involvement in the internal affairs of conflict-ridden states. As part of this framework, peace-building is directly addressed as the "responsibility to rebuild" (para. 2.29, 5.1-5.21). This serves to move further intervention away from traditional military connotations towards local and rebuilding measures.

\section{iii) Peace-building in practice}

Current UN peace-building practice sits somewhere between a vision-based commitment to "the responsibility to protect" and a more conservative belief in peace-building to further the aim of the pacific union of liberal states (Lidén 2006: 37). ${ }^{12}$ As noted in the Boutros-Ghali's original proposals for peace-building, liberal peace-building is but a subset of the potential activities that could be considered peace-building (Paris and Sisk 2009: 14). However it is peace-building which is clearly emphasised in UN documents:

A mission's mandate should include peace-building and incorporate such elements as institution-building and the promotion of good governance and the rule of law, by assisting the parties to develop legitimate and broad-based institutions...

\footnotetext{
${ }^{12}$ For a more detailed discussion of the different graduations of peace-building directing practice see Richmond The Transformation of Peace (Basingstoke: Palgrave, 2005). Heathershaw 'Unpacking the Liberal Peace: The Dividing and Merging of Peacebuilding Discourses', Millennium - Journal of International Studies, 36 (2008), 597. Michael Banks, 'Four Conceptions of Peace', in Denis J. D. Sandole and Ingrid Sandole-Staroste (eds.), Conflict Management and Problem Solving: Interpersonal to International Applications (F.Pinter; London, 1987), 259-74.
} 
Strengthening state institutions, increasing political participation, engaging in land reform, strengthening civil society, finding ways to respect ethnic identities: all are seen as ways to improve the prospects for peaceful governance. The aim of peace-building is to build the social, economic and political institutions and attitudes that will prevent the inevitable conflicts that every society generates from turning into violent conflicts. In effect, peacebuilding is also the front line of preventive action (Report of the SecretaryGeneral 2001, para $9 \& 10)$

Newman, Paris and Richmond, therefore, define peace-building as more closely akin to peace-building in the "promotion of democracy, market-based economic reforms and a range of other institutions associated with 'modern' states” (2009a: 1). There are of course a number of other tasks which concern stability - such as security and safety along with the provision of basic services and return of refugees - which overlap with peace-keeping, and humanitarian and development assistance to other UN activities. And while peacebuilding itself is not formally defined by the UN (United Nations Peacebuilding Support Office 2010: 5), Newman et al's definition is strengthened by the peace-building strategies - and the prominence afforded them - as outlined in the UN's mission mandates.

The idea that democracy causes peace has had important implications. As Paris has observed, all UN operations in the 1990s "sought to transform war-shattered states into liberal democracies as quickly as possible" (Paris 2004: 5). "Peace-building is unapologetically seen as the central objective of any peace operation" accordingly to Brahimi, the Special Advisor to the UN Secretary-General (2007: 4). In 1994, the mandate of the UN Mission in Haiti authorised coercive measures to promote democracy for the first time (United Nations Security Council 1994a). Operations in Kosovo, East Timor and Sierra Leone in 1999 marked the beginning of a new generation of peacebuilding missions, with even greater focus on building conditions for basic stability together with liberalisation. The mandates of these missions were substantially more extensive than for previous operations and clear peace-building strategies were incorporated into the objectives (Paris and Sisk 2009: 7) The mandate of the UN Interim Administration Mission in Kosovo sets out the usual security provisions as well as elements of peace-building in establishing an interim administration to build provisional 
institutions for democratic self-government, elections, and economic reform (United Nations Security Council 1999, 10(c), (e) and (g)). The UN Assistance Mission to East Timor's mandate directs the development of functioning state institutions, and the organisation and overseeing of elections. Similarly, for the UN Mission in South Sudan building and strengthening state institutions was given critical priority. Building core state institutions was the overarching goal even before the job of assessing what work was required was done (para 3(a)).

There is a consensus that peace-building has political, social, economic, security and legal dimensions, each of which requires attention. However to distinguish it from development, peace-building is understood to be a political project where legitimate political authority is created to avoid violence resuming. For UN peace-building, inspired by liberal internationalist ideology and with the aim of replicating the liberal western state, the focus is specifically on the technical exercise of institution-building:

\footnotetext{
Functioning government, political, market and social institutions have long been recognized as prerequisites for establishing popular confidence in the State and preventing violent conflict. Institutions - defined broadly as the rules of the game and the organizations that frame and enforce them - provide the incentives and constraints that shape political, economic and social interaction" (Report of the Secretary-General
} 2012, para 43)

Institution building along with sustained international support are seen as critical actions to prevent relapses into violence and to produce more resilient societies (Report of the Secretary-General 2012). As Richmond (2010) observes, the main focus remains on the top level and the reverse engineering in official processes with international experts prescribing knowledge, procedures and structures and has, thus resembled more a system of governance as opposed to a reconciliatory process.

\section{iv) The UN's peace-building record and lesson learned}

While the emphasis on liberal peace-building is clear, the UN's record of peace-building practice is less so. The assessment provided in this section is supported where necessary by evaluations from external parties who contribute to peace-building and the wider academic community. There is no easy framework for evaluation due to the fact that the UN's formal learning infrastructure has been under-resourced and knowledge collection 
unsystematic. This is not to say that learning has not taken place, but that it makes it difficult to present clear suggestions for reform based on that learning (for further elabortion on learning and change see: Susanna Campbell 2008). Two points will be explored. Firstly, that the goal of establishing domestic peace and stability through the introduction of political and economic liberalisation has not been a great success. And secondly, while a large number of key lessons have been learned and put into practice there remains a number of key dilemmas which are as yet unresolved.

Reflecting on the UN's first decade of peace-building Annan (Report of the SecretaryGeneral 2001, para 4) observed:

The United Nations has faced many difficult and complicated conflicts. While it is possible to point to several successes during this past decade, it must also be acknowledged that there have been cases where efforts fell short of objectives... more than once during the last 10 years the United Nations has withdrawn a peacekeeping operation, or dramatically altered its mandate, only to see the situation remain unstable, or sink into renewed violence

Successful cases include reforming systems of governance that became responsive to people's basic needs at the local, regional, and national levels (Report of the SecretaryGeneral 2001, para 12). While no specific examples are given in UN documents, Namibia and Mozambique are sometimes identified in the literature (Chesterman et al. 2005; Cutillo 2007). These, however, did not strictly-speaking follow civil conflict, since the withdrawal of South Africa in both cases brought about resolution of conflict (Paris 2004: 135-47). Subsequent complex missions in less favourable conditions have been associated with terrible tragedy - genocide, deteriorating security, stalemates and the return of violence after UN withdrawal - albeit not always on the same scale as before (Report of the Secretary-General 2006; Security Council 1999; United Nations General Assembly 1999). There is strong evidence of relapses into armed conflict and also of new conflicts emerging in places where peace-building has failed, as well as the reversedevelopment that this conflict then produces (Call and Cousens 2008; Collier et al. 2003). A 2010 UN report on peace-building noted:

The tragic consequences of failed peace agreements in the 1990s (e.g. Angola), renewed conflicts (e.g. Haiti and Rwanda) and protracted wars (e.g. Afghanistan, Sudan, DRC) 
highlighted the need for the UN to develop new approaches to the challenges of building sustainable peace in complex emergencies and intra-state conflicts. The emergence of multidimensional peace operations, the creation of new conflict units (e.g. UNDP/BCPR) and the design of new service lines (e.g. SSR, DDR and the rule of law) demonstrated the converging interest among humanitarian, development, political, security and human rights actors to help prevent and resolve conflict and to build sustainable peace. Relapse into violence in Haiti and Timor-Leste following UN interventions there reinforced the need for carefully-planned, well-coordinated exit strategies to prevent relapses and to lay the foundations for sustainable peace. (United Nations Peacebuilding Support Office 2010: 45)

The UN has undoubted achieved a number of positive results. Encouragingly there is decreasing levels and intensity of armed conflicts (Human Security Centre 2005, 2011). Success rates are however hard to define due to the much disputed definition of "success". International peace efforts must be part of this record but precisely how is unclear (Call and Cousens 2008; Doyle and Sambanis 2006). If success, however, is defined broadly as the ability to establish a stable and enduring democratic political system, then the UN's assessment is of failure. This conclusion is widely supported in the academic literature (Fukuyama 2005a; Paris 2004; Paris and Sisk 2009). Following elections in Angola (1992) and Liberia (1997) conflict returned. In other cases such as Cambodia, BiH, Tajikistan as Lyons (2009: 91) points out elections have served as war termination but with only a secondary, limited and arguably damaging relationship to democratization.

Whatever the measure, even in more positive instances such as in Cambodia, Takikistan and most recently Burundi, success is not widely embraced, and caveats abound - virtual peace, dictatorship, instability, continuing violence, serious underlying antagonisms, highly disputed governance structures (Heathershaw 2008: 337-39; Human Rights Watch 2012; Lund 2003; Mac Ginty 2006c; Richmond and Franks 2007). An important finding of Lunds' (2003) study of a large number of UN peace-building missions is that the record is very mixed even at the most basic level of ending the threat of major violence once a security presence withdraws - or negative peace.

One of the possible explanations for this is that the demand for UN assistance in the early post-war years was so great that learning struggled to keep up. As Paris and Sisk (2009) document in their comprehensive study of missions, early problems in Angola (1992), 
Rwanda (1994), Cambodia (1992) led to a reorientation of strategy towards the construction of effective, legitimate governmental institutions in transitional states such as Timor Leste (1999), Kosovo (1999) and Sierra Leone (1999). Liden et al (2009: 587) observe attempts to replicate these efforts in Afghanistan (2001) and Iraq (2003) have severely weakened the credibility of liberal international peace-building due to a lack of international and local legitimacy, and continued resistance and violence and general insecurity. Unfortunately at a fundamental level the liberal peace-building project has been given "an aggressive face in global politics" in part due to the reaction of the US to 9/11 and the "war on terror. This has hampered the illiberal peace-buildings appeal as the purported carrier of human rights and democracy (Duffield 2007; Lidén et al. 2009: 587).

The UN and others observe that efforts by the UN's Department of Peacekeeping Operation's Lessons Learned Unit did not have a great deal of impacts on practice, and there was no mechanism for learning across the course of a mission, let alone developing best practice (Dahrendorf 2003; Report of the Secretary-General 2000, para 229). Where attempts were made to transfer experience from one mission to another, this was often transferred in a one-size-fits-all manner leading to suboptimal outcomes (Dahrendorf 2003: vi). An example of the problem of early learning is exit strategies. Here elections were regarded as a signalling democratic stabilization and guaranteed a timely withdrawal (Chesterman 2004a; United Nations 2003). Benner et al (2011: 30) take this further arguing that a long-standing "culture of constant improvisation" meant that the UN bureaucracy strictly opposed efforts of evaluation or systematized knowledge acquisition which led to such problems (Benner et al., 2011: 30). This is supported by anecdotal observation by Chesterman (2004a: 256); [learning] has not [...] been one of the strengths of the United Nations. A senior Secretariat official describes this as an unwritten rule that 'no wheel shall go un-reinvented"'.

The UN has been alert to the ad-hoc nature of peace-building and undertook to learn and better identify institutional machinery for peace-building (Annan 2005). Annan appointed a panel of experts under Brahimi in 2000. The resulting report was the first UN attempt to complement systematically past mission experiences with existing academic knowledge (Report of the Secretary-General 2000). Learning was identified as the missing link between the temporary nature of specific missions and the reality of permanent engagement (ibid, p xiii). The report strongly called for reform and paved the 
way for a number of key developments. Under-Secretary-General Jean-Marie Guéhenno strengthened the Peacekeeping Best Practices Unit to understand better the change required of the UN and appointed David Harland to systematise knowledge acquisition and translate lessons into practice (Benner et al. 2007: 30). End-of-mission reports were supposed to be systematically collected from 2006 (ibid), plugging a gap where for example there is no end of mission report on Afghanistan or on Liberia - only an election report for the first and a start-up mission evaluation for the latter (Haeri and Blanc 2005; Peacekeeping Best Practices Unit 2004).

Further reform came in the establishment of a dedicated body to advance peace-building, strengthen coordination and create learning capacity: the Peacebuilding Commission (PBC) (United Nations General Assembly 2005a). As an intergovernmental body assisted by the new Peace Building Support Office and Peace Building Fund (a multi-donor trust), it provides sustained international attention towards countries undertaking peace-building and mobilises resource. However, the PBC is a weaker version of the body Annan (2005) proposed, diluted because consensus from member states was deemed necessary. It has more members, smaller staff, and lower capacity, is less dynamic, relies on voluntary contributions to the PBF, and has very little power with advisory status to the Security Council (United Nations General Assembly 2010). The mandated five-year review of the PBC called for improvements in nearly all areas of its work (United Nations General Assembly 2010). On the policy front, the UN's ability to reflect on practice can only be as good as its organisational learning mechanisms. As an agency of best practice, a number of commentators are doubtful that the PBC can be the missing link the Brahimi report identified or a driving force of UN peace-building change when it operates under such constraints (Malloch-Brown 2011; Pugh 2005).

Despite these constraints, a number of lessons have been learned. Key issues such as coordination and coherence, monitoring, capacity building, dependency, accountability and exit strategies are clearly addressed in a survey of UN reports (for example: Eide et al. 2005; Harland 2005; Report of the Secretary-General 2000, para. 210; United Nations 2003: 72; United Nations Peacebuilding Commission 2010). Of the many possible examples three illustrate the consensus across the UN's self-assessment and the supporting literature on lessons learned of a technical nature. The need for strong political support from the international community is identified. This includes adequate resource 
provision and political will as well as support from other organisations like the World Bank (Boutros-Ghali 1992: 27; Bratt 1997; Call and Cousens 2008; Carlsson et al. 1999; United Nations Peacebuilding Support Office 2010). In the case of Rwanda, the lack of interest from the US, Russia and China and the impartiality of France, Uganda and Zaire has been identified as hampering the UN's involvement and illustrates the tension between available means and desired ends. A second example is the importance of providing security for local populations through disarmament and demobilisation work and willingness on the part of the UN to enforce the settlement if required (Hampson 1996; Report of the Secretary-General 2000). The contrasting experience of Mozambique and El Salvador where security was conveyed to local populations against disasters in Rwanda and Cambodia illustrates this. And lastly timeframes for peace have been clearly recognised as needing to be more realistic, moving away from fast exit strategies to the recognition that building peace takes time (King and Mason 2006; OECD/DAC 2010; United Nations Peacebuilding Support Office 2010).

There are a number of other key issues which are less clearly resolved in the UN and supporting literature such as local ownership, cultural context, sustainability and legitimacy. This is not because the general agreement does not exist on their importance but rather because they move beyond the technical to raise institutional and operational dilemmas for the UN. As identified by Paris and Sisk these dilemmas can be framed in terms of establishing self-government through outside intervention, local ownership through international control, universal values promoted as remedies for local problems, a definitive break with the past in order to establish the liberal state and short term imperatives conflicting with longer-term objectives (Paris and Sisk 2009: 305-6).

The achievement of local ownership in particular has been comprehensively identified in UN literature as the answer to the undesired effects of peace-building such as dependency on the presence and administration of international assistance and the associated distortion of institutions and economy (International Commission on Intervention and State Sovereignty 2001, para 5.25-5.29; OECD 2011a: 11; United Nations Development Programme 2012). How this is "achieved" appears to relate to equally ill defined notions of participation, encouraging cooperation, establishing political processes that facilitate locals to take responsibility and strengthening national capacities (International Commission on Intervention and State Sovereignty 2001, para 5.31; Report of the 
Secretary-General 2012, see particularly para 62; United Nations Peacebuilding Support Office 2013).

There is no suggestion that the issues raised by UN peace-building practice are easy to overcome. The very nature of the peace-building enterprise is challenging. There has been much work done to overcome the ad-hoc nature of peace-building through committing to systemic knowledge gathering and the creation of institutional machinery. However, UN policy still prioritises security and development and it is noted that the UN has not assessed and tested their theories of peace reflecting as they do the liberal peace's aim to replicate the institutions of the modern state (Barnett et al. 2007). From the mixed record of post-conflict interventions one overarching lesson is clear; peace cannot be imposed on war-torn societies from the outside. How this translates into the work of the UN as the embodiment of the liberal internationalism with its strong commitment to the current practice of liberal peace-building has yet to be resolved. This was the exact finding made in a recent OECD report on stakeholder consultations to inform the first International Dialogue on Peace-building and Peace-building (OECD/DAC 2010: 29).

\section{BEYOND CRITIQUES OF LIBERAL PEACE-BUILDING}

Liberal peace-building continues to enjoy enhanced prestige at the international level. Yet the unresolved tensions addressed in the previous section and the very mixed record of practice, has left it open to scrutiny and review, making it the subject of the most important debates in peace and conflict literature. Concerns are widely expressed, and some reject the idea that peace can be constructed by third parties at all. Critiques from a variety of perspectives identify a number of flaws primarily concerning ontological and methodological narrowness (Beate 2007; Chandler 2006; Cooper 2007; Cramer 2006; Duffield 2001, 2007; Mac Ginty et al. 2007; Mac Ginty 2008; Newman et al. 2009a; Pugh et al. 2008; Richmond 2007). Putting aside claims from a realist counter-perspective such as "give war a chance" (Luttwak 1999), the critics can be broadly grouped into three categories; the problem solving approach advocated by those who seek to refine practice; those who seek to rebalance peace-building with more attention given to emancipatory strategies; and those that see liberal peace-building as fundamental flawed and damaging. 


\section{i) Problem-solving approach}

At the opposite end of the spectrum from realists are the problem solvers who see liberal peace-building as viable. They propose refinements to the process by which the liberal peace is implemented. King and Mason (2006: x) for example call for a fundamental rethinking of both the "institutional infrastructure and strategic approach." This is not a call for peace-building missions to be abandoned, but for greater resources: "Remedying the deep-rooted problems of post-conflict societies requires more robust instruments and longer time horizons" (ibid).

One of the most influential scholars in this area is Paris. As Heathershaw (2008: 612) concludes, Paris' research (1997) forms part of the qualitative evidence that the theory and practice of liberalising the economy and political system in post-conflict spaces have failed. Paris found that peace-through-liberalisation strategies had not changed the political culture of formerly non-liberal states and instead had contributed to violence rekindling or recreated historical sources of conflict (2004: 155). This, he argued, is due to little guidance provided to peace-builders as to the problem of constituting government (ibid, p. 174).

He does not reject liberal underpinnings or assumptions of peace-building but rather distinguishes between liberalism and liberalisation in arguing for "institutionalisation before liberalisation" (Paris 2004, 2006). Effective institutions can, he argues, serve to implement liberalism's principles until they become an unquestioned part of the society's political culture. This would be particularly relevant where the people have no immediate political or economic interest in change, or their power depends on the status quo. The identified refinements to peace-building practice, therefore, are greater coercive elements integrated into operations for them to be consistent with the aim of reverse-engineering the liberal peace. A strategy which Paris says is better characterised as "coercion before liberty" (2004: 46-51). A level of international governance akin to the UN's transitional administrative arrangements in $\mathrm{BiH}$ and Timor Leste would be required (ibid, p. 212).

The end goal remains liberal democracy, and the primary path to achieving this is through the construction of liberal institutions. Problem-solver critics do not address the fundamental tension in illiberal, undemocratic forms of intervention attempting to 
produce liberal democratic societies (Paris 2010) - as dilemma identified in the lesson learned section. They assume that coercive intervention justified for the long-term benefits of democracy and human rights will facilitate and ultimately be superceded by, legitimate post-conflict orders. In refining the prevailing approach, they are using the same mythologies based on the same ontological assumptions as liberal peace-building. Paris and others (Dobbins 2003; Dobbins et al. 2005) focus instead on missions with larger footprints in terms of financing, manpower and mandate as a way to achieve better outcomes (Zurcher 2011: 71).

Elements of these refinements have been incorporated into strategic policy and practice reflecting the rise of the peace-building discourse. Even the UN's PBC has followed this trend prioritising "good governance" above all else based upon perceived security threats to the Western states rather than on the resolution of conflict (United Nations Peacebuilding Commission 2007), tempered slightly by a commitment to local ownership. ${ }^{13}$ The peace-building framework implicitly acknowledges that the benefits of peace-building may be unequal and selective (Curtis 2012: 12). As Paris (2011b:159) argues, coercive peace-building is as good as it gets: "there is no realistic alternative to some form of liberal peace strategy." However outcomes can vary from the ideal liberal state because this is an elite-driven (international actors and local elites) process where political mechanisms created promote more accountability and "compel individuals to consult, deliberate, and negotiate with one another as they decide what they consider to be the good life" (Barnett and Zurcher 2009: 49). Indeed, it may only be the symbols and ceremonies of the liberal state that are recognisable.

\footnotetext{
13 Sabaratnam in her history of changes in international conflict management over the last 20 years concludes that the idea of "peace-building" appears to be disappearing altogether as policy actors seek to focus on states and regional security Meera Sabaratnam, 'The Liberal Peace? An Intellectual History of International Conflict Management, 1990-2010', in Susanna Campbell, David Chandler, and Meera Sabaratam (eds.), A Liberal Peace? The Problems and Practices of Peacebuilding (London: Zed Books 2011), 13-30. The new hierarchy is obvious in the OECD document which defines good governance and peace-building as activities which are to be understood as activities falling under the general umbrella of peace-building Oecd, 'Principles for Good International Engagement in Fragile States \& Situations', (Paris: Development Assistance Committee, OECD, 2007). The UK's Post Conflict Reconstruction Unit was renamed the Stabilisation Unit in late 2007 and in the US Department of State, the Office of the Coordinator for Reconstruction and Stabilization was created in 2004-5 to: "promote the security of the United States through improved coordination, planning, and implementation for reconstruction and stabilization assistance for foreign states and regions at risk of, in, or in transition from conflict or civil strife" The President of the United States, 'United States National Security Presidential Directive', NSPD-44 (Washington: The White House, 2005).
} 


\section{ii) Rebalancing of the liberal peace}

Another group of critics rejects coercion and urges for a rebalancing of liberal peacebuilding through more emancipatory and participatory perspectives. They believe that in overlooking local conditions liberal peace-building "violates the intrinsic moral value of the communities affected" because "norms are seen to be relative to specific communities, cultural identities and ways of being" (Hutchings 1999: 123). Emancipation is tied to particular contexts and locally derived meaning and values. As Bush (1996: 86) summarises:

the challenge of rebuilding war-torn societies is to nurture and create the political, economic and social space within which indigenous actors can identify, develop, and employ the resources necessary to build a peaceful, just, and prosperous society.

Communitarians are a subset of this group. They focus on local perspectives and territorial sovereignty in arguing for a lighter international footprint. Internationalism is therefore rejected, and the liberal democratic state is only relevant in contexts from which it arose (Hutchings 1999). For communitarians, peace can only be "communal" meaning that that it must be owned exclusively by the people of the society in question and must be designed to work with its unique characteristics. For example Cousens and Kumar (2001: 4) argue that the aim of peace-building should be "the construction or strengthening of authoritative and eventually, legitimate mechanisms to resolve internal conflict without violence". Therefore, international actors' roles should be limited to facilitating intergroup relations in procedural ways not affected by the cultural dimension (ibid, 186).

Other critics who advocate for rebalancing do not reject the liberal model outright but question the universalisation of liberal practices, values and institutions. Richmond, for example, rejects the assumption that peace has an "ontological stability" providing for it to be understood, defined and reverse engineered through the liberal state (Richmond 2005: 121). On a practical level peace-building in the most complex settings of SubSaharan African, Iraq or Afghanistan is at odds with state-centred analyses because the local context differs deeply from the liberal internationalist ideal type of states. Critics point to the weakness of state boundaries and structures, and the difficulties the international community has had in accepting the reality of statelessness and the 
possibility of new arrangements departing from state formation. In reality, the promise of economic reforms has not usually been recognised, and there has not been meaningful integration into the global financial, economic and trade systems (Selby 2009). The liberal model originated in the West where economic development was a fundamental precondition for the liberal peace (Hegre 2004: 41). In overlooking the realities of political order in this context liberal peace-building can do no more than create "no war, no peace" situations (Boege et al. 2008).

In refining liberal peace-building, these critics thus seek to destroy the ideological barriers between liberal peace-builders and their subjects (Boege et al. 2009; Lidén 2009; Mac Ginty 2008, 2011; Oliver Richmond and Mitchell 2012). They focus on mechanisms that address the underlying causes of conflict, including the structural imbalances within institutions, economies and societies at large. The status quo should not remain and, therefore, reverse engineering the liberal state where individuals and groups can continue practices of exclusion by controlling the spoils of the state will not bring peace. In removing imbalance, institution-building would need to be contextual (Jeong 2005). Most importantly rebalancing the liberal peace requires a move away from blueprints to focus on relationships, attitudes and behaviours of individuals and groups. An everyday focus would seek to alter internal social dynamics and address social injustices and inequalities. These changes cannot be externally imposed (T. Rose 2004: 74). The end goal, therefore, is not necessarily liberal peace-building but broader social and political transformation that can challenge conflict in peaceful ways using appropriate mechanisms, regardless of form. It is a return to politics before ideology where negotiation, consensus, consent and reconciliation form the basis of peace.

While communitarians reject individualism, they do not offer any particular political solutions. The hybrid strategies identify the everyday setting (local realities, institutions, knowledge and agency) to rebalance peace-building with the context in which practice is occurring. Richmond and Franks believe that through contact between liberal peacebuilding and local dynamics a post-liberal peace could emerge unencumbered by “idealistic prescriptions" (Richmond and Franks 2009a). While this concept could be helpful, researchers at the Berghof Research Center (Boege et al. 2008) agree that the implications for the strategy of international actors are unclear. 


\section{iii) Liberal model is fundamentally flawed and damaging}

The final group of critics rejects liberal peace-building as being ineffective and indeed damaging to local populations. Among them, critical theorists identify three main problems with liberal peace-building: it is conservative, hegemonic, and enforces inequalities. Pugh (2004) and Duffield (2001: 23-26) view liberal peace-building as maintaining the status quo. They focus on the global order accusing liberal peace-building of reinforcing current global political and economic order through the commitment to the liberal peace. The liberal zone of peace is seen as an elite club with benefits sustained by the global distribution of power, wealth and security (Bellamy and Williams 2004b). Hegemony is achieved in an "ideational" (Tadjbakhsh and Richmond 2011: 226) way through the dominance of the cultural and ideological trait of liberalism. It is reinforced in material ways through the unjust principles of the way power and wealth are organised in international politics including within international organisations (Pugh 2005: 23-42). Liberal peace-building has been used to gain power and serve economic and geostrategic needs and the "responsibility to protect" has legitimised and given moral authority to the mainstreaming of this in practice (Chandler 2004: 3-4; 2010; Duffield 2001: 75). Indeed, the "responsibility to protect" doctrine is not seen as a radical redefinition of sovereignty because it is still centred on the authority of the state (Warner 2003).

Liberal peace-building, these critics claim, enforces inequalities at the international level and domestically. They point out that democratization invariably produces competitions, loser and winners. Fast-paced economic liberalisation, in particular, is seen as a coercive enterprise which results in inequality, exclusion, underdevelopment and the increased likelihood of further violence (Pugh 2004; Pugh et al. 2008). The neo-liberal economic system is seen as one of inclusion and exclusion where the prosperous benefit and the interests of the needy are undermined (Bellamy and Williams 2004a). Bellamy and Williams (ibid) point to empirical evidence in the Human Development Reports, which questions the relationship between liberal democratic capitalism and development for post-conflict societies. This is in line with Galtung's (1969) theory of structural causes of conflict. Here exclusion and dependency are seen as a form of structural violence which can lead to real warfare - even civil war - on the margins of the liberal peace. Unless the global politics of contemporary conflict is taken into account, conflict will continue. 
Like the previous group of critics, critical theorists accept that the liberal peace is relevant only to the context in which it developed (Duffield 2007; Pugh 2008; Pugh et al. 2008: 290-7). However, they accuse the problem-solvers of merely adjusting and "shoring up" the liberal peace without subjecting it to real scrutiny (Ramsbotham et al. 2011: 402). Support here comes from the post-modernists. They point to persuasive critiques of modernity in the West (Bauman 1989; Durkheim 1893; Habermas 1990, 1998b; Lyotard 1984; Nietzsche 2008; Weber 1947, among others). These critiques do not appear to have dented the almost "evangelical" (Darby 2004: 8) optimism in the emancipatory potential of the democratic peace promoted by liberal internationalism which continues the modernisation of the developed world on a global scale. As Beate (2007) observes the liberal world underpinning modernisation theories addressed above. These policies survived and led to a reincarnation of such theories and policies under a new name - for example, the 80's Regan administration's democracy promotion. (Paris 2004: 32). From this position they then take issue with the method of reverse engineering the liberal peace through the transplantation of Western models of social, political and economic organisation onto post-conflict societies.

Critical theorists too reject the importance placed on outdated statehood and sovereignty. As McGrew (2000: 410) argues "just at the historical moment when liberal democracy is being transformed by the forces of globalization it is proposed to erect a version of it at the global level". The intra-state wars of the post-Cold War era are not even truly "civil" - often crossing borders and the economic and political logic of states. Therefore peacebuilding must consider the global, regional and local agendas (Duffield 2001).

Lastly critical theorists and postmodernists do not think that the liberal peace can live up to its own principles. Human rights and democracy depend on individual autonomy, and where this does not exist, these liberal norms will only appear to be in place. As Chandler (2011: 187) concludes, liberal institutionalism:

... reduces law to an administrative code, politics to technocratic decision-making, democratic and civil rights to those of supplicant rather than the citizen, replaces the citizenry with civil society, and the promise of capitalist modernity with pro-poor poverty reduction. To conceptualise this inversion of basic liberal assumptions and ontologies as "liberalism" would be to make the word meaningless... 
Postmodernists believe the promotion of grand narratives is based on flawed presumptions of the emancipatory and peaceful potential of modern society (Darby 2009). They would focus instead on what causes oppression and insecurity, and seek political community that was contextually relevant - not housed in a state structure if this causes detriment to some (Carothers 2002). Critical theorists recognise that while local actors can be fluid and have multiple identities, that they have agency and capacity and may express their existence through resistance, co-option, and the transformation of peace (Pugh et al. 2008).

Much of the critical theorists' energies are devoted to exposing present hegemonic abuse and relatively little to suggesting future practical alternatives. They do not seem to discriminate between practices that may have emancipatory potential from those that clearly do not - instead placing all current peace-building efforts under the "liberal" banner. Lessons learned, for example, are just more problem-solving. Thus while postmodernists pose a fundamental challenge to the current international order and architecture of liberal peace-building they do not provide specifics as to how political community is contextually achieved (Archibugi, Held \& Köhler, 1998a; Falk, 1995; Habermas, 1998; Held, 1995: 279-280; Held \& Archibugi, 1995; Hutchings, 1999: 161).

\section{FINDING COMMON GROUND IN THE LITERATURE TO REVEAL A GAP FOR RESEARCH}

Most critical literature tends to shy away from concrete solutions. However, some familiar themes can be found in the spectrum of critiques and in the UN's self-assessment. While liberal peace-building is recognised for the most part as a laudable enterprise, reverse-engineering the liberal peace, it is a very limited strategy for peace. The literature instead focuses on ideas surrounding "local ownership", as the core missing parts of peace-building practice. This section briefly looks at the common ground before searching for the reconciliation of local ownership with liberal peace-building. This exercise reveals a gap for further research. 


\section{i) Reconciling local ownership and peace-building practice: emerging from the critical literature and UN assessment}

Despite concerns over western triumphalism, liberal peace-building does attempt to build the capacity for peaceful ways of challenging and resolving conflict through holding elections and institutionalizing democratic governance. Post-conflict peace-building missions are recognised as having achieved a great deal in terms of stability and termination of violence in the immediate pause of the post-conflict period, but have been less successful in building peace long term (Paris 2004; Report of the Secretary-General's High-Level Panel on Threats Challenges and Change 2004; T. Rose 2004). Reverseengineering the liberal peace was perhaps the obvious (and often only) option on the table in the immediate post-Cold War period. The nature of local life, however, is far more complex than international intervention affords in its templates and prescriptions. However, Duffield concedes (2001), that without liberal peace-building many societies may well have not had the assistance of large-scale peace-building since its agencies, and economic and political support often are driven by liberal states.

Notwithstanding variations in language there is concern over the liberal peace's ontological and methodological narrowness. Three points illustrate the problem. Representing the problem solvers, Fukuyama (2005b) acknowledges that there is much we do not know about "transferring" strong institutions to developing countries. There is also emerging consensus on the limits of rapid transition to a liberal state economic model which notably did not occur all at once in the history of western liberal states. And finally, it is doubtful whether peace can be legitimately constructed for others through the transference of technical knowledge and frameworks without addressing local characteristics, culture, and priorities (United Nations Peacebuilding Support Office 2013; Willett 2006). Liberal peace-building is thus administering to incidences of conflict, not conflict causes (Mac Ginty 2010). On the more critical side, Mac Ginty (2006c: 3) concludes that as a technocratic process of "ticking boxes, counting heads and weapons, amending constitutions..." liberal peace-building cannot be an emancipatory process but resembles a stabilisation exercise.

There is however also agreement that the primary responsibility for finding peace lies with those who have been affected by violent conflict. While the idea of local ownership 
has rhetorical acceptance (OECD 2011b; Report of the Secretary-General 2012; United Nations Development Programme 2012) - as has been outlined in this chapter - it lacks official definition or the depth of clarity needed to inform policy. Notions of bottom-up peace-building have been incorporated into peace-building programmes (Ramsbotham et al. 2011: 226-30; World Bank 2003). However, the priority is clearly still institutionbuilding and making sure these institutions run effectively (OECD 2011a; World Bank 2011). Liberal peace-building's constituting elements (e.g. democratization, economic liberalization, neoliberal development, human rights, and the rule of law) have been widely adopted and propagated as non-negotiable which may explain the disregard for context-specific history and politics. Liberal peace policy is locked into top down peacebuilding (OECD 2008) - not only in Kosovo, Iraq, Afghanistan and Libya but in the most current contexts of Burundi, the Democratic Republic of Congo, Liberia, Sierra Leone and South Sudan (De Coning 2012: 108). And while the focus continues to be on international or regional peace, rather than on the space for peace to develop in the particular post-conflict context, the "who" in policy remains the "state" rather than people or communities (Richmond 2009a: 566). David Roberts refers to this as "achieving the technical" while ignoring "achieving the political" (Roberts 2011: 420).

The unresolved nature of the twin focuses of local ownership and institution-building measures to "fix" states, while subtle, is nonetheless also apparent in the literature. In the majority of Chesterman et al's (2005) Making States Work - one of the best collections of literature on post-conflict peace-building - the contributors implicitly adopt a Weberian perspective of the state, concentrating on the challenges that government institutions face in maintaining the monopoly on coercive power. Only in the conclusion do the editors regroup to discuss issues of local ownership, local needs and transitional justice. This discussion bears little relation to the evidence presented in the case studies or to peace-building promoted in the book as a whole.

Notwithstanding the popularity of "local ownership" rhetoric, a clear u-turn is identified in the literature and political discourses away from a holistic approach and comprehensively to peace-building as policy and practice. Within the scholarly literature notions of reconciliation and rehabilitation once featured prominently in mainstream thinking about conflict management (Crocker et al. 2001) emphasising that approaches 
from different traditions might be brought together to address failures in peace-building practice. The change in both intellectual and political direction is illustrated by the US Institute for Peace's third compendium on conflict management which jettisoned references to "peace" and "reconciliation" when addressing uses and limits of government in conflict management. The editors consciously turned away from peace because of the new security environment characterised by "rogue states" "terrorism", "weapons of mass destruction" and "conflict" (Crocker et al. 2007: 4) reflecting the change echoed in the dramatic proliferation of literature on state failure and implications for interveners (Chesterman et al. 2005; Fukuyama 2004; Ghani and Lockhart 2008; R. Rotberg 2004b).

The debate around the manifestations of local ownership and its consequences has therefore been shallow to date. This is not surprising according to Kymlicka as there is a pattern of liberal blindness to cultural difference, particularly in the way individual human rights has overshadowed the idea of minority rights at the UN (Kymlicka 1995; Ryan 2007). Therefore, Campbell has termed policy on "local ownership" as co-option rather than adoption to marginalise the critiques of top-down approaches (Stephen Campbell 2011: 43). When "local ownership" rhetoric is employed without being fleshed out and when the post-conflict society is treated as an isolated entity or as a tactic to promote the liberal peace, this accusation seems to have some merit (Richmond and Franks 2009b: 6).

Yet as the problem solvers critics observe, current practice even with modification and co-option of local ownership will not build the kind of liberal states envisaged by Kant that are able for the most part to channel conflict in peaceful ways. Mainstream peacebuilding theory has to face the problem of promoting a model that does not work in many contexts. Few solutions are at the level of the community emerging from conflict. In attempting to preserve peace-buildings positive intentions, a more holistic understanding of peace-building seems to be required. The lessons of existing peace-building practice and the overwhelming academic knowledge embodied in the critical literature highlight strategies for peace finding acceptance in the local culture. It would appear that the implication of this is the space for non-technocratic ideas for peace and negotiation of peace frameworks to arise from the owners of the peace's experience, culture, identities and context. This is not to over-romanticise traditional or indigenous practices of peace and goverance that reinforce the power of elites in a negative way or impose social conformity in a brutal way (T. Chopra 2010; Mac Ginty 2008). However, there are often 
local practices for dealing with social challenges and local understanding of the "rule of law" that can be built upon as well as perceptions of peace and how that might be achieved (Donais 2012). Where there is not, space for these processes to develop is even more imperative if challenging. Legitimacy then flows from the points of view of the population, from continued deliberation and dialogue, not from the timetable of donors with blueprints of post-conflict peace-building.

\section{ii) Identifying gap for research}

The lack of meaningful attention to local ownership and associated transformation of peace-building within the liberal peace-building framework has been clearly identified in the literature (Chesterman 2007; Donais 2009). There appears to be significant dissatisfaction with and increasing resistance to the liberal peace as experienced by local populations in post-conflict contexts (Tadjbakhsh and Schoistwohl 2008). However the complimentary wealth of critical literature of liberal peace-building, while noting the inner contradictions and unsuitability of reverse engineering methodology, contains very few solutions available for consideration. It focuses instead on responding to the dominant practice of the liberal peace rather than providing a greater understanding of local contextually relevant alternatives.

Yes, this is theoretical. These are essential two competing - but not necessarily contradictory - version of the peace-building theory. Liberal peace-building which holds liberalization as the key to solving conflict, relying as has been explored in this chapter on the liberal peace thesis which is the belief that liberal democracy and liberal marketisation will lead to greater peace. In practice, liberal peace-building is by necessary quite intrusive and the transition to local ownership remains a marginal concern.

In identifying local ownership as a key to mitigating failure thus far, the literature reviewed in this chapter clearly points towards a more holistic interpretation of peacebuilding that is broader than the technocratic enterprise of liberal state-building and understands the underlying causes of conflict and indeed how peace is negotiated locally.

The implications of this are two-fold. Firstly an approach to peace is required that encompasses these concerns. I argue this can be found in the theories and norms emerging 
under the umbrella of "conflict transformation" because this approach focuses on conflict being transformed primarily within the society in question through local learning, understanding, and change. Conflict transformation pushes beyond the status quo and could be used as a framework to explore the tentative emergence of an alternative peacebuilding paradigm that is much more in tune with the local actors, issues, rules. Due to the emerging nature of conflict transformation as a coherent theory and local ownership as a concept, the current discussion has gaps and is based on theory largely untested in the field and, therefore, has an uncertain trajectory and conclusions. However, it seems necessary that theory does continue to develop and explore in order to distil holistic possibilities for post-conflict peace-building.

Secondly in shifting the focus from technical solutions to the local a gap is revealed in the lack of understanding of possibilities of autochthonous solutions for governance that channels conflict in peaceful ways. I, therefore, propose to investigate the building blocks of pacifying Leviathan in the immediacy of the post-conflict pause and the shape of the 'space' that might be needed for autochthonous solutions based that learning to emerge.

\section{CONCLUSION}

In the early decades of the $21^{\text {st }}$ century, there appears little doubt that liberal internationalism has emerged as a significant peace tradition. This chapter has explained the dominance of the liberal peace model through a review of its enlightenment theoretical origins - particularly Kant's perpetual peace - the ascendency of the liberal internationalist ideology in the 20th century, the persuasiveness of the separate democratic peace as revitalised by Doyle in the 1980s, and the evolution of the liberal internationalist peace-building means to the wider international purpose of security, order and peace through the evolution of the concept of (liberal) peace-building at the UN.

As peace-building has evolved, it is not at all clear that the chosen method - reverseengineering the liberal peace - is the solution to the post-Cold War concern with intrastate conflict. Rapid liberalisation has actually triggered violence and ignores the complexity of transitions and the mismatch between expectations for rapid peace and processes that historically took much longer. The transplanting of imported and hence unfamiliar 
constitutional forms has been criticised but repeatedly resuscitated. Not surprisingly, paused-conflict states find it impossible to govern themselves with model solutions which fail to consider the richness of the national, cultural, political, and temporal context. Armed conflict has often resumed.

The UN faced early challenges prompted by the sudden demand for peace-building coupled with unsystematic mechanisms for institutional learning. Where lessons have been implemented, they have tended to encompass the most technical aspects of peacebuilding - coherence, mandates, efficiency, coordination and monitoring. A range of reforms has strengthened knowledge collection so as to inform policy and practice. However, a number of unresolved dilemmas remain. The most serious of which is that the liberal peace is characterised by the diminution of the local and oddly, of peace itself. This is because the focus on structures in the sense of institution building can change without any real attention to individuals or culture, leaving group identities and antagonisms intact. Liberal peace-building of this kind appears to be a much more conservative interpretation of peace-building than Boutros-Ghali intended when he warned that social grievance and political freedom would need to be addressed. Kant too, in the prioritising republican constitutions, makes clear that peace is contingent on indigenous democracy.

In reviewing the literature, it is evident that the liberal peace-building as it is currently conceived has prioritised security and order at the expense of testing and assessing whether current policy actually assists in building sustainable peace. The critical literature too identifies a number of fundamental flaws concerning the liberal peace's methodological and ontological narrowness. Standardised processes and endpoint for those activities do not mesh with context-specific factors. Solutions are limited. The problem solvers call for more coercive peace-building to build the façade of liberal states while the critical theorists would do away with the entire practice. Those who seek to rebalance liberal peace-building hope to soften external prescriptions through social and political transformation that can challenge conflict in peaceful ways using appropriate mechanisms, regardless of form. It is a return to politics before ideology where negotiation, consensus, consent and reconciliation form the basis of peace. 
There is certainly scope for this recognised in the general agreement evident in the UN and critical literature that the primary responsibility for finding peace lies with those who have been affected by violent conflict. In shifting the focus from technical solutions to the local, a gap is revealed in the lack of understanding of possibilities of autochthonous solutions for governance that channels conflict in peaceful ways. Rather than the liberal peace, I propose to use the more holistic approach of conflict transformation to inform this research as it is primarily concerned with local learning, understanding, and change. 


\section{3: The approach of conflict transformation}

\section{INTRODUCTION}

The liberal peace-building dominance addressed in chapter two is characterised as fastpaced, top down, ethnocentric project with universalistic assumptions. It problems in theory, as well as practice, were documented through exploration of the UN's lessons learned and the critical literature. The dominance of liberal internationalism and liberal peace-building is however just one peace traditions. Promising alternatives may be built on the basis of theories and norms emerging under the umbrella of "conflict transformation". Throughout human history conflict transformation has existed but as a field of study and practice it emerged in the 1990s incorporating some core ideas of contemporary conflict resolution. Briefly, conflict transformation holds that enduring peace requires that the underpinnings of actual or latent conflict must be transformed primarily internally through local learning, understanding, and change. There is no grand theory within the conflict transformation field. Instead, many isolated propositions and generalisations and countless analyses of social processes. This chapter serves to define the scope of the research through an exploration of the approach of conflict transformation.

\section{WHAT IS CONFLICT TRANSFORMATION?}

In the first part of this chapter the conflict transformation approach directing this is explained. This begins with a definition of conflict transformation and the similarities and differences between the three board approaches to conflict under the peace-building umbrella - to manage, settle or transform. Despite its newness as an approach conflict transformation has a strong theoretical influence. 
A complexity of terminology has often caused the parameters of these approaches to be unclear. How these differ from each other is a matter of some debate.

\section{i) Conflict approaches: management, resolution and transformation}

Conflict transformation seeks to transform conflict into something that is desired in a longer timeframe. It focuses not only on the content of the conflict but more importantly on the context and relationships between the actors involved. Conflict transformation is suited to post-conflict peace efforts as it is not driven by concerns simply to "solve" or "fix" undesired disputes but actually provides the ground to build something desired based on sufficient consensus, on learning.

Debate exists as to whether conflict transformation is a distinct field or approach (Botes 2003; C. Mitchell 2002; Ryan 2007). Adding to the confusion is the use of "conflict management", "conflict resolution" and "conflict transformation" interchangeably sometimes by academics and practitioners when referring to similar strategies. There is no doubt that conflict transformation has emerged out of decades of conflict resolution and management practice and rests on the same tradition of theorising about conflict. As such there is a significant overlap between the three approaches - particularly in attempting to alter the political will to change behaviour - but there are a number of crucial contrasting elements. ${ }^{14}$

Briefly, conflict management is anchored in political realism (see: Bercovitch 1984; Zartman 1995) and seeks to manage or contain conflict. It is the positive and constructive handling of difference and divergence underpinned by the notion that propensity to violence comes from already existing institutions and historical relationships and distribution of power (Bloomfield and Reilly 1998: 18; Miall 2004: 2). Conflict is inevitable and resolving it is not possible. Conflict management strategies attempt to move "zero-sum" into "non-zero sum" processes and, therefore, to end direct violence and enable agreement. This is often through the identification of key leaders with established power to negotiate an agreement. Conflict management tends to focus solely

\footnotetext{
${ }^{14}$ For a comprehensive discussion of the differences and similarities, see: Cordula Reimann, 'Assessing the State-of-the Art in Conflict Transformation', The Berghof Handbook for Conflict Transformation (Berlin: Berghof Research for Constructive Conflict Management 2004).
} 
on the third party with resources to exert pressure on the conflicting groups and to negotiate agreement. An illustration is the international nuclear and arms control treaties during the Cold War, which sought to ensure that the relationship between the major world powers did not get out of hand without addressing the underlying political issues (Wallensteen 2007: 4-5). More recent examples include the Sudan and Aceh peace accords (Ramsbotham et al. 2011; Richmond 2005: 89-96)

Next is the more comprehensive approach of conflict resolution which emphasises the underlying causes and fundamental needs that are at the root of conflict (Burton 1990: 31; Kelman and Cohen 1976; Ramsbotham et al. 2011). Conflict resolution, like peace research more generally, evolved as a critique of realism in international relations. Such theory developed in response to international wars that were largely "Clauswitzean affairs, fought out by power centres" (Miall et al. 1999: 15). In other words the conflicts tended to be between nation-states and were typically symmetrical in contrast to more recent patterns in conflicts that are internal or intrastate as well as being asymmetric, involve fragmented decision-making and often directed at citizens. As such this approach evolved from an elite-based civil society approach to a more general civil society and grassroots, approach (Paffenholz 2009). The aim is to develop: "processes of conflict resolution that appear to be acceptable to parties in dispute, and effective in resolving conflict" (Azar and Burton 1986: 1). This implies a goal of "ending" undesired conflicts in a relatively short time and focuses on the content of the particular conflict as something that is disputed and which gives rise to the conflict in the first place (Fetherston 2000). In other words, conflict resolution strategies are concerned with getting parties to reframe their existing positions. As Lederach (1995b: 201) argues resolution is a widely recognised term but "perhaps unintentionally, this term carries the connotation of a bias toward 'ending' a given crisis or at least its outward expression, without being sufficiently concerned with the deeper structural, cultural, and long-term relational aspects of conflict".

In practice, Ramsbotham et al (2011: 425) observes that in the Post-Cold war period conflict resolution became better know and widely invoked by aid and development agencies, international organisations and the media. Its increased prominence exposed it to raised expectations and sharp criticism. Conflict resolution has been tarred in much of the critical literature on the liberal peace and failed democratic efforts, unfairly in my 
view as the liberal peace of the previous chapter is only a caricature of conflict resolution. However, conflict resolution theory presumes that people, particularly third parties, can have some control or power over violence. As a theory of modernity, it presumes that scholars and practitioners can understand violent conflict, have power over it, solve it, and that it will cease to exist. Traditional conflict resolution from above has resulted in several unfortunate outcomes in this regard and are limited at best and counterproductive at worst (Kaldor 2001).

What has changed as referenced in the previous chapter and explored more fully by Ryan (2007: 43-45, 153-60) is recognition of the limits of top down interventionalism and at least a rhetorical acceptance of local culture and the need for ongoing, continuous processes, addressing root causes and building peace at multiple levels of society. It is here, Ryan argues that conflict transformation has perhaps emerged to refocus attention on conflict resolution basics that have been overshadowed (Ryan 2007: 154). Early conflict resolution practitioners believed very strongly that what was required was fundamental structural changes as well as changes in relationships for "resolutions" to be accepted, self-supported and durable and ultimately, sustainable (for example, see:Scimecca 1987).

The understanding of conflict transformation preferred here comes from the Berghof Foundation: "a complex process of changing the relationships, attitudes, interests, discourses and underlying structures that encourage and condition violent political conflict" (Austin et al. 2011: 9). ${ }^{15}$ At the very least this is a more holistic approach however some go further seeing conflict transformation as a complete conceptual departure from that which has come before (Curle 1990; Lederach 1995b; Rupesinghe 1995). For Lederarch (ibid) conflict transformation moves beyond the management or resolution of conflict and seeks to do more than mere eliminating or controlling conflict. Instead, it seeks to transform the conflict' creators through focusing on inherent dialectical process, transforming conflict dynamics and the relationship between the parties. Or as Väyrynen (1999: 151) states, a way to create "new social relations, institutions, and visions". Even those sceptical of the notion that conflict transformation

\footnotetext{
15 There are a number of definitions of conflict transformation .Those concerned with transformative mediation focus solely on individuals as amplified by the work of Bush \& Folger The Promise of Mediation (San Francisco: Jossey-Bass Publishers, 1994).
} 
is a distinct approach - such as Mitchell (2002) - concede that what best distinguishes this approach from the other two is the emphasis on structures and relationships. A strong underlying inference in the conflict transformation literature is it resolves conflict resolution major deficiencies. As Vayrynen states (1991: 4):

The bulk of conflict theory regards the issues, actors and interests as given and on that basis makes efforts to find a solution to mitigate or eliminate contradictions between them. Yet the issues, actors and interests change over time as a consequence of the social, economic and political dynamics of societies.

Notter \& Diamond (1996) argue that transformationists favour systemic chance and imply that conflict resolution cannot create the circumstances which would result in peaceful societies: "Transforming deep-rooted conflicts is only partly about "resolving" the issues of the conflict - the central issue is systemic change or transformation. Systems cannot be "resolved," but they can be transformed thus we use the term conflict transformation."

Others argue that conflict transformation represents conflict resolution at its deepest level which recognises the need for wide structural changes and relationship transformation for a durable solution, (C. Mitchell 2006: 15; Ramsbotham et al. 2011: 31). Conflict transformation as a term emerged Mitchell believes out of necessity due to the corruption of the conception of resolution - a term used to stand for "almost anything short of outright victory, defeat, and revenge as an outcome as well as for many processes involving overt violence ('bombing for peace') or covert coercion (economic sanctions to obtain parties' acquiescence to a dictated settlement)..." (C. Mitchell 2002: 1).

Whether it is a distinct approach or not, there is no doubt that it is holistic as evident in its theoretical influences.

\section{ii) Theoretical influences of conflict transformation}

Conflict transformation has a strong theoretical base despite its relative newness as a peace-building approach. Like peace studies generally it draws from many disciplines, including political philosophy, psychology, law, history, economics, public policy, international relations, governance, conflict theory and practice. 
There are existing transformative elements in normative theories of politics from the founders of conflict resolution. Of particular note is the work of: Galtung on negative and positive peace (introduced in the introductory chapter) and group dynamics, Curle's asymmetric relations theory, theories of non-violence and social transformation across many cultures offered by Sharp and others, Burton's provention concept and addressing deficits in human needs, Azar's often forgotten work on the formation but also the transformation of protracted conflict (see for example: P. Ackerman and DuVall 2000; Azar 1990; Burton 1990; H. Clark 2000; Curle 1971, 1996; Galtung 1996; Galtung and Jacobsen 2000; Krippendorf 1973; Senghaas 1973; Sharp 1973; Wehr et al. 1994).

Another source of influence is the extensive literature and major studies that have amassed on peace-building since the 1990s (J. Chopra 1998; Cousens and Kumar 2001; Jeong 2005, among many others). The critical literature explored in the previous chapter - while focused specifically on liberal peace-building - also shows many commonalities with the approach of conflict transformation. Some of this literature is suggestive of transformative elements including the Habermasian inspired emphasis on unscripted conversations and recognising diverse forms of community (Pugh et al. 2008), empowering locals, global solidarity and transforming the global order (Duffield 2007; Pugh et al. 2008). In this vein conflict transformation moves away from "universalist panaceas". As Richmond explains "peace" is a method and a process as opposed to a final end state. Indeed, the acceptance of difference is a method of peace and processes whereby agency is afforded to those crucial groups in society to develop their voices, ideas and identities (Richmond 2008: 147)

Much of this stretches towards to a cosmopolitan recognition of shared humanity and exposure to what Beck terms "otherness" (Beck 2006). Related to this is of course the impact of globalization - both positive and negative - including in resistance to its effects, globalization from below, international community and the responsibility to protect, international human rights, rise of intrastate conflict, global drivers of conflict such as environmental or systems of politico-economic networks that transcend state boundaries. One theme characterising the conflict transformation literature is the call for cosmopolitan or peaceful global civic society building (E. Boulding 1990; Kaldor and Luckham 2001). 
Lastly, conflict transformation has distanced itself from empirical approaches favouring normative and critical thought. This is not to say that there have not been valuable contributions to knowledge from the scientific approach. However, transformations with intangible and temporal elements are difficult to measure and, therefore, this approach instead favours narrative explanation or the role of storytelling.

\section{iii) Key features of conflict transformation}

Thus far a number of key features of conflict transformation are detectable. The key features of conflict transformation are actions that attempt to change the various characteristics and manifestations of conflict by looking at the underlying causes across a long timeframe with the aim to transform negative practices of addressing conflict into positive and constructive ones. This concerns dealing with the structural, behavioural and attitudinal aspects of conflict (Austin et al. 2011: 13; Fischer and Ropers 2004).

In order to provide greater clarity in this explanation of conflict transformation, adding to this definition is the expansion of several important aspects. They first are why conflict transformation is preferred; the second is how it works in practice and lastly who transforms conflict.

\section{Why conflict transformation?}

Far from merely being the in-vogue catch phrase of conflict theorists, conflict transformation is a response to the changing nature of conflict in international relations, particularly over the last twenty-five years. Contemporary conflicts are often protracted, moving in and out of violence regularly. These changes, Miall argues, has required continual adjustment of conflict theory (2004: 1). Bell-shaped or cyclical models of conflict phases are not useful here. These conflicts warp the societies, economies and regions in which they are centred. They contain a mixture of violent actions and nonviolent oppression and inequality. Such complexities stand in stark contrast to the relatively simple configurations assumed by conventional theories of conflict resolution, such as those which advocate win-win outcomes in simple two-party contests.

Burton and Azar's early work (1986) on the then newly emerging conflicts focused on the intercommunal dimension of intractable conflict and relations between identity groups. Such conflicts, they argued, are due to unfulfilled, underlying societal and 
universal human needs such as security, identity, equality, recognition and autonomy. These are deep rooted problems meaning that the conflict has created patterns that are part of the social system. When the humanitarian emergency or the like is under control, they questioned what strategies should be employed. Not being traditional interstate wars means there is no simple return to the status quo of mutual respect for territory. Peace thinking has had to adapt to address groups continuing to live together after violence between them had ceased. Deep rooted problems, therefore, need deep rooted changes (Leatherman et al. 1999: 50; Lederach 2003; Ramsbotham et al. 2011: 9). And as social conflicts it is likely that social change mechanisms must inform the solution. Van der Merwe noted in 1989 that the term "conflict resolution" could not encompass situations of gross injustice and inequalities built into the social and political system in relation to South Africa, as is also the case with the fundamental social problems of many deep rooted conflicts.

The conflict transformation approach is appropriate for situations where conflicting parties have a real relationship; they share an extensive past and probably will have an extensive future relationship. There is a clear link between transformations and causes of conflict, therefore, is seems appropriate to look at further transformation in the postconflict pause. As Väyrynen (1991) argued "as a matter of fact, many intractable conflicts of interests or values may find their solution only through the process of transformation" (p.4). Conflict transformation scholars use terms like "transcendence" (Galtung 1996), getting to the "epicentre" (Lederach 2003: 31) (p31) in order to address the limitations of other approaches in the a high number of conflicts re-emerging in places that were supposedly resolved (Call and Cousens 2008). Such deep changes necessitate addressing the structural and cultural background to the conflict. This means that it is not just the conflict dispute - or the "presenting window" in Lederach's terminology (2003 pp 48) but the entire process and the impact on parties, relationships and institutions which are fundamental. Social change is the aim of conflict resolution, not just the immediate issues which may simply transfer the conflict into non-violent but equally unjust and destructive ways over the long term.

This brings us to the how conflict transforms. Galtung identifies creative thinking as "new, sui generis, usually unexpected" - something radical to jolt groups out of their destructive relations (Galtung 1996: 96). Rather than some kind of end-state, 
transformation is more open-ended and indeed a continuous and never-ending process (Galtung 1996: 151; Väyrynen 1999). Conflict does not have a finite life. Conflict are instead seen as the waxing and waning of social interactions and, therefore, need to be transformed (Galtung 1995: 51). Transformation will take time, particularly because creative ideas and process will take even longer to be valued and cement (Galtung 2000: 11; Volkan 1997: 226). Therefore pressuring divided societies to hold early elections, for example, can lead to disastrous results. A long term commitment may be difficult to sustain but seems necessary when solutions may cause further problems, and without which there may be incomplete reconciliation.

\section{How does conflict transformation occur?}

A simplistic explanation as to how conflict transformation works in practice is that the conflict itself is transformed denoting some kind of sequence of necessary transitional steps which not only removes the situational elements behind the conflict but necessitates transformation of the conflict groups' attitudes and relationship s. The "what" part of this equation is more difficult to explain due to the fact that conflicts, as Mitchell (2002), Väyrynen (1991: 4) and Ramsbotham et al (2011: 26) point out, are inherently dynamic phenomena.

In addressing what is being transformed Lederach emphasises both the need for personal and relationship change, away from destructive interaction patterns and change towards justice, equality and non-violent conflict resolution in the overall social system. Lederach (1998) adds these overarching aims: the social-psychological (issues regarding identity, self-esteem, emotion, trauma and grief); the socioeconomic (providing financial aid, retraining, employment and development); the social-political (matters pertaining to demobilisation, disarmament, troop integration, and professionalisation); and the spiritual (concerns about healing, forgiveness, and mutual acknowledgement). This approach provides for the how of transformation and helps theorists and those in the field to come to terms with the need to address post-conflict peace-building in a more holistic manner.

All these activities are part of a wider search for relational reconciliation through which relationships must be restored. Perhaps the most clearly articulated explanations of what is being transformed, as touched on in the introductory chapter, is Väyrynen's (1991). Conflict transformation involves four dimensions - the structure of inter-group relations, 
actors, rules and issues. The first is actor transformation, either through changes in existing groups or the introduction of new ones. The second - issue transformation manifests in changes to the relative importance of conflict issues particularly controversial issues and fostering common interest. Next rule transformation sees the redefinition of norms actors are expected to follow in their relationships. And the last structural transformation - where the structure of conflict is transformed by a change in power distribution or degree of interdependence. To this Miall (2004) has added the fifth dimension of "context transformation", meaning significant change in the surrounding regional or global setting.

Drawing on Väyrynen's categories the transformation approach, therefore, assumes that changes in most if not all of these dimensions will be necessary post-conflict - to be "successful" - not simply the absence of violence, or establishing the shell of democratic structures or resolving the immediate conflict dispute. These ties back to the idea of positive peace through increasing justice in direct interaction and social structures (Berghof Foundation 1999-2014; Lederach 2003: 4).

Kriesberg (1989: 337) summarises the how seemingly intractable conflicts move to tractability:
Such movement arises from changes in the relationship between adversaries, from changes within one of the major adversaries, and from changes in the struggle's external context. Often elements from two or three of these sources converge and combine together to form ways out of the conflict. The process that brings about the transformation of an intractable conflict into a tractable one entails the interaction between a set of changing conditions and of new policies, both long-term and short.

While this may seem vague, it is honest. As Väyrynen cautions while transformation is better suited to situations of complex conflict than resolution, it is indeterminate, and the consequences can be hard to predict. There will be a number of incremental transformations which change the conflict in positive but possibly also less positive ways. Sometimes changes happen unintentionally as a by-product of broader changes that parties within the conflict neither planned nor could avoid but to which they had to adjust. The focus, therefore, must be on social transformation so that the mitigation of violence is not lost in what he calls the "normative approach" focusing on the improvement of society - as is the accusation levelled against the liberal peace (Väyrynen 1999). 
Another unknown is the time factor. Conceptual shifts and learning will take time - just as Fisher (2000: 13) argues valuing life and prosperity over what glory, power, and honour did in the western experience. Whilst there is no agreed upon minimum period for sustainability, most policy makers and researchers share a sense that it takes at least decades for peace to take hold and a further few generations for conflict to truly transform (Lederach 1995a, 1997). Sometimes only in retrospect can transformational change in relationships between groups be recognised. After the fact, it may be easy to identify the factors leading up to the change but at the time, as Gladwell (2000: 12) explains, the tipping point is: "the moment of critical mass, the threshold, the boiling point."

\section{Who does conflict transformation?}

The transformation approach operates at multiple levels. A notable change in the conflict literature is the move from seeing intervention as the primary responsibility of external agencies towards appreciating the many different actors and levels (not just elites) involved in conflict transformation. And particularly the role of internal third parties or indigenous peacemakers (Crocker et al. 2007; Lund 2001; van Tongeren et al. 2005).

The "who" therefore is a mix of transformative leadership as well as transformation work directed at the wider community. As Spies (2006: 3) and Miall (2004) have summarised, the value of outsider assistance in cases of deep-rooted and protracted conflicts - while undisputed - cannot inhibit the extent to which people own the design and outcome of transformation processes from inception determine the likelihood of sustainability of those efforts.

Related to this is another key feature in terms of procedural elements - that of empowerment. Empowerment of individuals, groups and organizations to negotiate new relationships and structures for their post-conflict society validates and provides space for involvement in conflict transformation (Francis 1994; Lederach 1995b: 212). Adversarial relations are primarily transformed through interaction between adversaries. This is supported by much Schwerin's (1995) definition of "empowerment" which reiterates the basic components of transformational theory, referring to both direct as well as indirect ways to personal, relational and systemic change such as knowledge and skills, selfesteem, self-efficacy, political awareness, rights and responsibilities, social participation, and access to psychological, social and material resources. 
Traditional third party involvement, therefore, is directed at supporting internal actors and coordinating external peace efforts. International assistance particularly intervention may have been needed to transform the conflict. In the post-conflict pause, outside actors often play vital roles in supporting peace agreements through implementation assistance and monitoring, as well as stopping the flow of military or other support to one or more of the parties making the continuation or renewal of fighting more difficult.

Lederach (1995a) believes an infrastructure for establishing peace is needed. This helps to legitimise the process but also draws together multiple levels of the population. Three levels that need to be impacted (Lederach 1998). The top-level elite leadership concerns the fewest people, perhaps just a handful of key actors. On the other hand, the grassroots level represents the greatest number of people and the population at large. Lederach's (1997) framework differs significantly from other approaches because it includes the grassroots level and argues for a bottom-up approach. It is, however, the middle range which holds the potential for sustaining, in this case, the pacification of the Leviathan because while "important ideas and practical efforts do emerge" from the grassroots, for many people conflict resolution is "an unaffordable luxury" (51). And although politicians may decide for "the people", acting on behalf of or in spite of them, even the most powerful warlords or groups leaders need popular support. It makes no sense to think of a return to any kind of peace simply in terms of the apex of the pyramid.

\section{MOVING BEYOND THE STATUS QUO: ADDRESSING THE UTOPIAN PERCEPTION OF CONFLICT TRANSFORMATION THEORY}

No approach to something as multi-facet and difficult as conflict will be without thorny issue, dilemmas and challenges. Multiple perspectives and analysis and possible intervention integrated into long-term peace processes tend to be time consuming, nonlinear and fitful. Positive transformation of conflict through "people power" and the peace process in Northern Ireland and South Africa are often swamped by the challenges of Bosnia and Rwanda - but as Mitchell (2011) reminds positive transformations do undoubtedly take place and obstacles are overcome. 
The challenges are indeed numerous. Conflict transformation will not happen smoothly or simultaneously for all parties in conflict. One side may be more receptive to peace while others or subgroups may prefer to hold out for better arrangements, and still others favour mutual accommodation. Conflict transformation challenges the status quo and, therefore, may be unsettling and indeed provoke a backlash from those groups in society who may be disempowered or stand to lose - having a vested interest in the status quo. In addition, conflict transformation is always multi-dimensional and occurs in different degrees among different parties. It is accepted that notions of a harmony of interests are difficult and related to this - letting go of the past may be difficult and needs to be carefully addressed. For all these reasons, scholars emphasis that transformations often advance in positive fashion and then fall back before advancing again (S. Fisher and Zimina 2009; Lederach and Appelby 2010).

Popper (1961) warning against the tyrannical elements in some transformative approaches and to value incremental change. In post-conflict contexts, this does not mean that previous warring parties must suddenly embrace each other but rather that issues can be resolved through compromise, common sense, imagination and commitment to justice. The reality may be there is no one adequate peace strategy but rather a number of difference ones that will depend on the constraints and opportunities that exist in each place.

Many challenges exist including navigating between local and global dynamics and finding ways to address and encourage exchange between a much wider range of actors. There are some obvious competing pressures when external intervention assistance is required with local empowerment. Particularly if ignoring the unattractive aspects of local cultures lead to ethno-nationalism and the possibility of deepening group identities. There are also the large number of dimensions of the experience of violent conflict and a wide range of possible approaches which could contribute to the rebuilding of relationships, communities and polities. Being self-critical in addressing the past is no small task. Tensions could obviously arise if dialogue focuses too heavily on relations without balancing this structural change towards imaging a future.

It is not about fixing or resolving, but supporting and implementing workable structures in some areas so that people in paused-conflict states can negotiate governance 
arrangements of their own choosing, not simply react to fear for their future. A clear shared sovereignty framework with consent for international referees will assist in this regard, as part of the international social contract.

If, as it is argued here, conflict is the result of particular social structures and institutions favouring a dominant group: "we cannot hope to remove or alleviate those causes without altering those structures" and changing the relationships (Sluka 1992: 31). As is noted above a criticism of conflict transformation approach is that it exaggerates the differences between it and others approaches. I have chosen to focus mainly on an interpretation of conflict transformation for its distance from connotations of "resolution" and "management" which suggest normative solutions and other conceptual pitfalls such as an emphasis on containment and control. And the notion of "transformation" fittingly conveys the role and dynamics of social conflict, moving as it does through phases of transforming relationships and social organising.

The point is that there is no rapid fix to overcome war and violence, understanding why conflict transformation is so hard is the basic first step which forms the bulk of this thesis. Here in lies the main criticism of the conflict transformation approach. It is simply that it needs further development as to how change occurs (C. Mitchell 2002). It is the aim of this research to investigate the evidence of a small part of that.

\section{CONCLUSION}

There is no singular model of conflict transformation because conflict is by its very nature dynamic, unstable, context specific, etc. What is clear however is that semantic shift is necessary - from "resolution" to engaging with and transforming relationships, interests, discourses and the culture of the society that supports the continuation of violent or destructive conflict. How it occurs is far from prescribed but there are a number of common themes. The most significant of which include: innovative thinking, an emphasis on deep and wide-ranging change, understanding conflict as dynamic and potentially an agent of positive change, a focus on empowerment and sensitivity to local culture, an awareness that long term processes where quick fixes are not appropriate, an emphasis on working at all levels of society and on processes of self-reflection by both insiders or 
outsiders. Complementary roles can be played in a long term process of rebuilding by a range of actors: those within the conflicting groups, within the wider society, and outside assistance. Transformation is about ongoing support, not simply mediation and peace agreements. It is about gradual transformation through a series of changes and a range of actors playing important roles (Rupesinghe 1995, 1998).

Conflict transformation cannot be easily dismissed as semantics or as utopian. But neither is transformation precise or clear approach. There is no one single strategy as is more clearly reduced in the liberal internationalist paradigm. What counts as transformation will vary in different contexts. For this reason, some have called for precision to be added.

We begin this task by turning to groupism and the transformation of actors in the conflict. The following chapter will untangle primordial explanations for human violence to be able to come to a balanced discussion on how humans also cooperate and manage multiple and overlapping identities. Unfortunately, the phenomenon of groupism in conflict creates 'us' and 'them'. The perception of shared interests, of commonality, or security may contribute towards the generation of alternative identities that may reduce the ethnicity's salience and reorientate larger groups around governance. 


\section{INTRODUCTION}

Before the rise of liberal internationalism, it was assumed that understanding human nature's unconscious and destructive tendencies could afford a unique and privileged position from which to understand resolves conflict. In the early $20^{\text {th }}$ century, Einstein and Freud, for example, were asked whether human nature made war inevitable (see also Freud 1933). ${ }^{16}$ Governments and insurgents, France and Germany, Protestants and Catholics, the bourgeois and the aristocracy, Israelis and Palestinians, Indians and Pakistanis, whites and blacks, employers and employees, Muslims and Christians, are all examples of groups waging seemingly intractable conflict. Sometimes the result of these conflicts were genocide, mass murder, war, conquest, slavery, apartheid, exploitation. However rather than solely being "killer apes" (Dart 1953), it is argued here that a less sensational explanation of human nature is correct - humans are capable of inconceivable violence and genetic aggression but also incredible sociability and cooperation. Cooperative interaction amongst individuals has been a big part of human survival.

Intergroup (e.g., racial, ethnic, or religious) conflict occurs when opponents have a sense of collective identity about themselves and their adversary. As Kreisberg (Kriesberg 2003b) describes - where each side believes the fight is between 'us' and 'them'. Excessive identification with a particular group can lead to intergroup conflict. But identity is a social construct maintained for social or political reasons. These boundaries can be transcended.

Despite overwhelming evidence to the contrary, the belief in the intractability of ethnic conflict has strengthened primordial explanations for human behaviour, rather than addressing the collective fears for the future, societal madness and human needs which sustain them. Institutional theorists have also struggled to governance strategies that are

\footnotetext{
${ }^{16}$ The Why War Letters were a public exchange on the origins of war and human aggression between Albert Einstein and Freud and were written at the behest of the International Institute of Intellectual Cooperation (a committee of the League of Nations).
} 
flexible and moderating influences. The power-sharing literature stemming from Lijphart $(1977,1985,1990,1999,2002)$ and Horowitz $(1985,1990,1997,1998,2005)$ is particularly problematic in addressing groupism in paused-conflict governance. As topdown containment approaches, in practice they have reinforced division because as emphasised in the preceding chapter, alternative learning has not developed.

\section{THE MYTH OF HUMAN NATURE}

The literature on war and conflict is immense. For the purposes of this research, the dimension that underpins all other angles from which war can be approached (historical, economic, ideological, ethical, political, etc.), is human nature. There is no doubt that the history of humanity is one of extraordinary violence, but the question is why? The idea that human behaviour is inevitable has at times dominated discourse to such an extent, that game theorists once promoted a non-cooperative angle, based on the perceived wisdom of biology at the time. There are broadly two polar opposite schools of thought on the relationship between war (or violent conflict) and human nature. One views human nature as "man the hunter" or "demonic males" and the other as "nobel savages" or "peaceful societies".

The idea that war stems from "instinct" or "innate" or "biological" drive has a long and controversial history. Despite a veneer of civility, war or violence is seen as distinctly human. In other words, it has been bred in. Scientist Raymond Dart (1953) for example believes that humans are at the bottom "killer apes". ${ }^{17}$ With the development of Darwin's theory of evolution and discoveries of apelike human ancestors in Africa a long line of theory spawned, often inferring behaviours and basic moral underpinnings. Dart originally saw early hominids as gentle fruit eaters who hunted small game and birds' eggs to supplement their diet. He changed his mind however after interpreting animal bones as primate weapons and holes found in ancient skulls as being caused by weapon-

\footnotetext{
17 This theme can be seen in William Golding's Lord of the Flies. American anthropologist S. L. Washburns's edited volume Man the Hunter related human hunting to human morality, and was popularised in playwright Robert Ardrey's books on human origins and behaviour, the first of which argues that mankind's very success as a species has been largely dependent on its ability to kill, see: African Genesis: A Personal Investigation into the Animal Origins and Nature of Man (New York; Macmillan Publishing Co, 1961).
} 
wielding fellow hominids. He became convinced that they were armed big game hunters who killed their own kind and feasted on one another's flesh. Early humans were (Dart 1953: 209):

confirmed killers: carnivorous creatures that seized living quarries by violence, battered them to death, tore apart their broken bodies, dismembered them limb from limb, shaking their ravenous thirst with the hot blood of victims and greedily devouring livid writhing flesh. The loathsome cruelty of mankind to man . . . is explicable only in terms of man's carnivorous and cannibalistic origin . . . the world-wide scalping, head-hunting, bodymutilating and necrophilia practices of mankind in proclaiming this common bloodlust differentiator, this predaceous habit, this mark of Cain that separates man dietetically from his anthropoidal relatives and allies him rather with the deadliest of Carnivora.

Cartmill (1996) links Dart's vision of human morality to early Greek and Christian views where the depravity of human nature is related to notions of original sin. Equally, Dart's evidence for "man the hunter" was weak. On closer examination, his particular vision of the human hunter-killer hypothesis was dispelled by his protégé Brain (1981). Brain realised that bones associated with man-apes were exactly like those left by leopards and hyenas. The round holes and dents in the fossil skulls matched perfectly with leopard fangs and with impressions of rocks pressing against the buried fossils. It seems likely that hominids were the hunted - living in fear of big cats - and not hunters.

Evidence of earlier, lethal, human violence is, therefore, ambiguous at best. Despite this the legacy of the dark and pessimistic view of humankind can be seen even today in Wrangham and Peterson's (1996; Wrangham 1999) controversial but popular contributions to the field: "chimpanzee-like violence preceded and paved the way for human war, making modern humans the dazed survivors of a continuous, 5-million-year habit of lethal aggression" (Wrangham and Peterson: 63). From field observations on conspecific killing among wild chimpanzees, they hypothesise that because chimpanzees often kill for no discernible short-term gain and assuming that longer-term payoffs are opaque to the animals involved, they must instead be motivated by an innate "dominance drive" (Wrangham and Peterson 1996: 182-99; Wrangham 1999: 14-22). Male chimpanzees - and by extension human males - seek out low-cost opportunities to kill a strategy that returns net evolutionary benefits in the long term (not immediate payoffs) like mating opportunities, food and other resources (Wrangham 1999: 15-16). Such 
findings of violence among our ancestors and primate cousins have perpetuated what anthropologist Sussman calls "the 5 o'clock news" view of human nature (Whipps 2006). Just as the daily news' shows follow the dictum, "if it bleeds, it leads", so many accounts of human behaviour emphasise conflict.

Among the various challenges to Wrangham's work, Browning's (1998) reconstructive case study of the men of Reserve Police Battalion 101 who participated in the Nazis' Final Solution in Poland provides concrete human (not chimpanzee) evidence against innate drives. The approximately five hundred mainly middle-aged, working class German men - "ordinary men" as Browning calls them -were tasked with perpetrating horrific acts of violence. In this case the massacre of 38,000 Jews and deportation of a further 45,000 to extermination camps. This was coupled with low-cost opportunities to kill. Following Wrangham, eager participation should have been the outcome. Incentives to participate included the anticipation of career advancement after the war and at the same time there were no discernible costs as the Jews were Polish and therefore not compatriots. Also, these men mainly came from the most philo-Semitic parts of Germany and had been immersed in a deluge of racist and anti-Semitic propaganda designating Jews as a moral threat to Germany. This indoctrination characterised their training and was ongoing (Browning 1998: 184). As armed agents, they were also not at threat from personal injury from their unarmed targets.

There was a group who were increasingly "enthusiastic killers" - volunteering to hunt Jews and pull the trigger in firing squads. However, the study reveals that others actively avoided killing. While most of the remainder did not take up opportunities to kill, even in some cases disobeyed orders when they were not being monitored (Browning 1998: 168, 84). Browning notes that: "almost all of them - a least initially - were horrified and disgusted by what they were doing" (Ibid, 184) and following the first massacre a "sense of shame and horror... pervaded the barracks" (Ibid, 69). ${ }^{18}$ Browning's work draws on the Milgram experiments, showing that aside from the enthusiastic few, killers were not ideologically (or biologically) motivated. Social pressures - the fear of ridiculed or

\footnotetext{
${ }^{18}$ In Browning's 1998 edition (the first being published in 1991) he provides a plethora of evidence from pre-1945 echoing these same feelings including from Himmler himself who ordered those no longer able to take the psychological stresses to report to their superior officer. See: Ernst Klee, Willi Dressen, and Volker Riess (eds.), "The Good Old Days": The Holocaust as Seen by Its Perpetrators and Bystanders (New York: Free Press, 1988) at 82.
} 
punishment - were sufficient to induce human beings, in general, to join in the slaughter. In that respect, it is "normal" or part of human nature to go along with killing, but not some innate dominance drive.

In contrast to Dart and Wrangham, Hart and Sussman (2005) represent the opposed view contending humans are naturally not killers since our ancestors were hunted not hunters. This follows Rousseau's description of first humans in his Discourse on the Origins of Inequality Among Men (1754) as "noble savages" who lived in a golden age that "mankind was formed ever to remain in". Conflict occurred when humans organised themselves in societies with unnatural laws (private property and monogamy for example). ${ }^{19}$ The American sociologist Sumner, appears to have been one of the first to adopt the Rousseauan view, writing in 1911 that: "primitive man "might be described as a peaceful animal" who "dreads" war' (cited in Keeley 1996: 8). In spite of the presumption that most societies were peaceful in the past, anthropologists have had difficulty finding ethnographically known peaceful people. ${ }^{20}$ There are relatively few examples of internally peaceful societies that are also non-warring: the !Kung Bushman who live in the boundary area of Botswana and Namibia, the Copper and the Ingalik Eskimo, the Gehusi of lowland New Guinea, the Semang of peninsular Malaysia among others (Fry 2007; Fry et al. 2008; LeBlanc 2003). ${ }^{21}$

\footnotetext{
${ }^{19}$ Rousseau's ideas where challenged at the time by empirical evidence from those who encountered native peoples round the world. In one such instance, for example, the aboriginal Tasmanians - who at that time had had no known contact with others - meet a group of unarmed French emissaries and attacked them. Such encounters strengthened the view that Rousseau's belief in "noble savages" was naïve. The English social psychologist March promoted the Rousseauan stance in relation to the Dani of New Guinea, the typical warrior people in his view. See: He concludes that it is misleading to talk of "warfare" among these warriors because the battles are not akin to warfare associated with the struggle for survival in a world of scarcity and need.

${ }^{20}$ Without good evidence in low-density nomadic populations, it cannot be inferred that warfare was absent in Palaeolithic populations. The reverse is also true - there is no evidence that warfare was ubiquitous and inevitable. However the body of evidence for warfare before the onset of agriculture and the associated patterns of sedentism and surplus production is small but undeniable, and generally seems characterised by some degree of residential stability. See: Jonathan Haas, 'Warfare and the Evolution of Culture', in Gary M Feinman and Theron Douglas Price (eds.), Archaeology at the Millennium: A Sourcebook (New York: Kluwer Academic/Plenum Publishers, 2001), 329-50.

${ }^{21}$ The Peaceful Societies project lists 25 (inducing the Amish) on strict criteria and acknowledges that there are incidences of violence, such as homicide, among some of those selected. See http://www.peacefulsocieties.org (last accessed August 2010).
} 


\section{i) Middle ground}

Unlike Rousseau's “noble savage”, Hobbes' (1651) addressed the question of the "state of nature" and came to a different conclusion. All human beings desire what is good for them, and aspire to peace so long as it is in the interests of the individual. But if danger is perceived then it is reasonable to adopt any means to secure self-preservation - what Locke terms the "rights of nature". If these rights are enforced, the "state of nature" means life will inevitably be "solitary, poor, nasty, brutish and short". A stable society requires individuals to give up the rights of nature and to invest in decision-making in a sovereign group (or individual) able to act for the long-term good. War, in Hobbes' conception, is a social condition that can only be controlled or averted through covenants.

For Rousseau on one hand, humans are by nature non-violent but are led to violence by unnatural social constraints. For Hobbes, man has the natural capacity for violence but is constrained by social convention and strong leadership. Researchers have concluded from the on-again, off-again pattern of warfare that the notion that war is an inevitable consequence of human nature is incorrect.

Ethnographer Malinowski wrote in 1941 that: "anthropology has done more harm than good in confusing the issue by... depicting human ancestry as living in a golden age of perpetual peace" (cited in Keeley 1996: 8). The Rousseauan camp has been seriously discredited by data-based studies including ethnographies of hunter-gatherer societies (Ember 1978; Keeley 1996; Wrangham and Peterson 1996). Independent groups, with the lack of exposure to external constraints, had adult male mortality rates of between 20 to 30 percent (Wrangham and Peterson 1996: 77). As anthropologist Keeley points out, while the more recent the large-scale battles of the $20^{\text {th }}$ century may not mirror those of the more primitive cultures, primitive warfare can be openly ferocious ${ }^{22}$ and more deadly in a quantitative sense (the loss of 20 out of two to three hundred annually being substantial) than subscribers of the Rousseauan view hold it to be. While contact with Western civilisations has most likely made some socieites more warlike and violent,

\footnotetext{
${ }^{22}$ A raiding-technique example Keeley gives, which is common to groups as varied as the Bering Straits Eskimo and the Mae Enga of New Guinea, is to quietly surround enemy houses before dawn and slaughter the sleeping occupants by thrusting spears through the thin walls, firing arrows through the doorways and smoke holes, or firing directly at the occupants as they emerge from the structure after setting it on fire. See: Lawrence Keeley, War before Civilization (New York: Oxford University Press, 1996) at 65.
} 
Keeley's (1996: 174) study refutes any notion that pre-state, tribal people did not engage in violent warfare:

The facts recovered by ethnographers and archaeologists indicate unequivocally that primitive and prehistoric warfare was just as terrible and effective as the historic and civilised versions. War is hell whether it is fought with wooden spears or napalm.

The point is that if war is as deeply rooted in our biology as the demonic apes' camp suggest, then it would be there all the time (Haas 2001). War - defined as armed conflict resulting in 1,000 plus deaths per year - has infrequently occurred between states since World War II and civil wars declined sharply after peaking in the early 1990s. Conflicts today mainly consist of guerilla wars, insurgencies, and terrorism which Mueller (2004) calls the "remnants of war." He rejects biological explanations for the trend, noting that "testosterone levels seem to be as high as ever" (Mueller 2009: 313). While he acknowledges that many political scientists still consider war to be "an inevitable part of international and domestic life," Mueller firmly states that "a continuing decline in war does seem to be an entirely reasonable prospect" (Ibid, 319). The emergence of prehistoric warfare is linked to growing population density, diminished food sources and the separation of people into culturally distinct groups. After the creation of "us" and "them", violence became a complex response to environmental problems. Interesting the word "host" means both a warlike group and a person who receives another graciously. Both word senses have a common deviation. When did the stranger become the enemy? However, groups that are at war in one generation are at peace in the next. For instance, Vikings during the Middle Ages contrasting with their peaceful Scandinavian descendants or the militaristic, aggressive early $20^{\text {th }}$ century nations of Germany and Japan who embraced pacifism, albeit after catastrophic defeats. The same group dynamics - cohesion and solidarity - which historically benefited victorious communities in presenting a united front against an enemy, have parallels in non-violent examples such as sports games and trade rules.

Neither end of the spectrum assists in understanding paused-conflict governance and group dynamics in isolation, but a middle ground provides answers. Smith (2007) makes a compelling case that while Homo sapiens is indeed far and away "the most dangerous animal", it also endowed with a deep aversion to killing. Humans are capable of inconceivable violence and genetic aggression but also incredible sociability and 
cooperation. As biologist Bigelow (1969: 3) remarked: "We are without doubt the most cooperative and the most ferocious animals that ever inhabited the earth." Humans, and most primates have a tendency to be hostile to non-group members, but it is nurture/environment, not nature/biology, which determines the level of aggression displayed by individuals (de Waal 1989). ${ }^{23}$ Also, as de Waal was able to prove through studying human's closest relatives, fostering interdependence between monkeys and apes prompted cooperation. ${ }^{24}$ Fry adds (2007: xi, 2): "violent chimps and baboons can reconcile after fights, have cooperative, altruistic relationships" and humans "have a substantial capacity for dealing with conflicts non-violently".

Cooperative behaviour in humans can be seen throughout history. Biology explains this through kin altruism and repeated interaction which applies to nonhuman species as well as humans. However, there are also capacities that are much more highly developed in humans (unique even) which account for the scale and the range of cooperative activities. Human cognitive, linguistic and physical capacities are identified as allowing the norms of social conduct to form and social instiutions to regulate these, the psychological capacity to internalise these norms regardless of the motivations such as self- or groupinterest (Johnson et al. 2003) (Bowles and Gintis 2003).

Smith's thesis is that war has been part of human history, in one form or other, since prehistoric times. However where he departs from Dart is in proposing that humans have an innate ambivalence about war (2007: xiv): This is as long-standing as the converse and is especially popular among military scholars (Dyer 1985; Montagu 1976; Tinbergen 1968). War is not "inhuman" or "animal like" but has been "normal" and has been "expectable" for thousands, perhaps millions, of years. War is also "idiocy" in that "war is grotesque" (D. L. Smith 2007: 6-7). What in human nature makes us resort to war? Smith argues that war benefited our ancestors (as victors), and this is why the disposition to war lives on in us. However, he does not think it is inevitable (Ibid, 27). Le Blanc (2007) agrees recent advances in biology which reveal that there aggressive and competative behaviour can be an example by primary genetic components. There are no

\footnotetext{
${ }^{23}$ For example, de Waal found in the case of the ordinarily "incorrigibly" aggressive rehesus monkeys, they grew up to be kinder and gentler when raised by mild-manner, stump-tail monkeys. He has also reduced conflict among monkeys and apes by increasing their interdependence - forcing them to cooperate to obtain food - and ensuring their equal access to food.

${ }^{24}$ His studies of the bonobos (pan paniscus chimpanzees)
} 
such genetic components leading to cooperative behaviour. Dawkins (1976) argued in the 1970 s that genes were "selfish" which explained altruism at the individual level in nature. More recent studies suggest a genetic effect on prosocial behaviours, especially on altruism.

\section{ii) Ordinary men and women}

From those who have had first hand experience of the worst of humanity come similar thoughts. Auschwitz survivor, Levi, rejected the idea that his Nazi oppressors were specially chosen monsters - some subspecies of human more prone to atavistic tendencies than others. He refused to accept the assumption of original sin. At the conclusion of The Drowned and the Saved (Levi 1989: 202) Levi indicates that he has been repeatedly asked what his "torturers" were like - his answer:

\footnotetext{
The term torturer alludes to our ex-guardians, the SS, and is in my opinion inappropriate: it brings to mind twisted individuals, ill-born, sadists, afflicted by the original flaw. Instead, they were made of the same cloth as we, they were average human brings, averagely intelligent, averagely wicked: save the exceptions, they were not monsters, they had our face, but they had been reared badly.
}

The Enlightenment faith in education as "inoculation" against savagery was strong prior to WWII; many were challenged by the persecution in Nazi Germany. Wiesel (1994: 27) states in his memoirs:

\footnotetext{
The truth is that, in spite of everything we knew about Nazi Germany, we had an inexplicable confidence in German culture and humanism. We kept telling ourselves that this was, after all, a civilised people, that we must not give credence to exaggerated rumours about its army's behaviour.
}

Such examples serve as a warning against complacency. In Elias' writing on German violence towards groups conquered they conquered in the East during WWII (i.e., Jews, Slavs and others), he sees the direct impact being worldwide revulsion by the mass Naziled slaughter. The shock was greater still; he contend, precisely because the people believed that such acts of barbarity were, for Europeans, a thing of the past. Europeans assumed they were more "civilised" and "morally better" as part of their "nature". Yet this was perhaps partly an illusion, a social-Darwinist pride in being less "savage" than 
their ancestors and those in the developing world - but this had not been seriously investigated. The Nazi episode served as a reminder that:

... restraints against violence are not symptoms of superiority of the nature of "civilised" nations, not eternal characteristics of their racial or ethnic make-up, but aspects of a specific type of social development which has resulted in more differentiated and stable social control of the means of violence and... a corresponding type of conscience-formation. (Elias 1971: 106-07)

The international tribunal at The Hague is prosecuting war crimes and crimes against humanity and has documented many tales of horror from the break-up of former Yugoslavia. Despicable in their brutality as well as their pervasiveness during nearly three years of madness, these atrocities, sadly were not the work of a small number of isolated zealots. They were perpetrated by ordinary men and women, no different than most of us (Arendt 1964). Why?

In "groupism" lies the answer. Gil-White (2001) has argued the human brain has a module for thinking about humans as groups. He gave the example of ethnic groups as sharing an invisible essence. Due to evolution humans are quick to categorise other "species" even when they look and sound the same. Smith describes this categorisation of peoples as "imagined communities" that hold together "mythic commonalities" which are intangible and impossible to define, such as blood (D. L. Smith 2007: 167).

\section{GROUP IDENTITY}

Conflict between groups has been a popular topic long before the events of September 11, 2001. One of the few psychoanalysts to have extensive first-hand experience in international relations and conflict resolution is Volkan (1997, 2004). His contribution serves to build a vital link between political science and psychology, providing crucial insights into the relationship and interplay between individual and group identity. Our group identities are: "the end result of an historical continuity, geographical reality, a myth of common beginning, and other shared events: they evolve naturally. They are neither bad nor good, but a natural phenomenon" (Volkan 1997: 22). Cooperative interaction amongst self-interested individuals has been a big part of survival, and some 
of the strongest interpersonal bonds are formed by ties of "blood" and "ethnicity". Feeling a sense of oneness with a group can motivate humans to be altruistic and self-sacrificing. Most people, however, see themselves as having multiple identities. Nothing could be more obvious than the fact that the same person could be a New Zealand citizen, of Chinese ancestry, vegetarian, female, heterosexual, a supporter of gay rights, without any contradiction.

Sen (2006) emphasises that while identification with a particular group can facilitate within-group cooperation (see also Putnam 1995), excessive identification can lead to inter-group conflict. As long as groups, and the rituals that separate them are not "rigidified", they function positively. However when threatened by conflict, group members cling stubbornly to experiences of their large group affiliations and these large group processes become dominant, subsuming or subjugating personal identity (Volkan 2004: 107, 262). Huntington's prediction of a new world order through a 'clash of civilisations" is perhaps the same "us" versus "them" reductive argument used by many previously including Christ in Matthew 12:30 (He who is not with Me is against Me) and since: Mussolini in fascist Italy (O con noi o contro di noi - You're either with us or against us) and Bush on September 202001 ("Either you are with us, or you are with the terrorists"). Put another way, the danger becomes apparent - Deputy Governor John Danforth states in Arthur Miller's The Crucible (1952: Act II): "But you must understand, sir, that a person is either with this court or he must be counted against it, there is no road between." The "us" in our conscious choice compels us to feel solidarity with a group, sometimes without but sometimes with, a strong notion of an outside group: "them." Thus, while groups promote the creation of "social capital" that allows their members to coexist peacefully, trading networks to emerge, public goods to be produced, the asymmetrical relationship between insiders and outsiders can be a source of polarisation. It is when people focus on one strand of identity, Sen believes, the trouble begins. Groups are left vulnerable to manipulation by chauvinists, often "ethnic" such as in the HinduMuslim riots that he witnessed as a child in British India, and also in Nazi Germany, Rwanda and Yugoslavia and beyond. Sen's warning is equally true of the literature and practice of conflict resolution about identity, where the one strand that is given the most attention is "ethnicity". 


\section{i) The assumption of ethnic intransigence}

Group identity-based conflict can be difficult to manage. For people who share the same collective identity believe they have both common interests and common fate. "Ethnicity" is often pinpointed as the most complex cleavage for a democracy to manage (Diamond et al. 1995b: 42). The literature in Horowitz's (2005: vii-ix) view, therefore, is “obsessed with ethnic conflict" and exclusively focused "on ethnic groups as building blocks of the polity". Friberg (1993) and Lederach (1997) suggest calling them "identity conflicts" given the rigid connotations that ethnicity draws. "Identity" also connotes that group affinity is, in the overwhelming majority of cases, malleable.

Like the dominance drive theory of human nature, the assumption that the nature and intensity of ethnic divisions are beyond transformation comes from primordial justifications of ethnicity as a fact of human existence. Ethnicity must have preceded any human social interaction and is thus unchanged by it. Ethnic groups are seen as natural, not historical and no explanations are offered as to how and why nations and ethnic groups seemingly appear, disappear and often reappear again. Intermarriage, migration and colonisation, resulting in multiethnic societies are also problematic for this view. Geertz (1963) for example, who was an influential proponent of the primordial school in the 1960s, attempted to argue that while ethnicity in itself is not primordial, humans' perception of it is. This is because their preceptions are embedded in their experience of the world and reinforced by the power of human "givens" such as blood ties, language, territory, and cultural differences. His work on the then new African states of the 1960s argued that they would find it difficult to act independently, because of the extent to which they would be hampered by their people's sense of self (ethnicity, locality, religion, tribalism, etc.).

There is no doubt that the salience of "ethnicity" increases during conflict, often sidelining other identities (gender, class, sexual orientation, class, profession, age). Sometimes the boundaries between such groups may have been drawn long before conflict broke out (very little interaction, intermarriage or indeed re-identification). It may equally be true that when the conflict is paused, the reduced threat of a common enemy can cause old group divisions to resurface. However, the nature or character of these groups is not intransigent. 
Instrumentalists view ethnic sentiments and loyalties as being cultivated by political leaders and intellectuals for political or material ends including state formation (Brass 1995, 1997) - or by ethnic groups themselves. They assume an ethnic consensus that initially does not exist. The fear of being victimised may cause groups to make calculated decisions to engage in violence. Others stress that ethnicity is socially constructed. Anderson, Diamond and Kriesberg believe people choose (or have enforced) a history and common ancestry and create, as much as discover, differences from others (B. Anderson 1991; Diamond et al. 1995a; Kriesberg 2003c). In the words of Linz and Stepan (1996: 366): "political identities are less primordial and fixed than contingent and changing. They are amenable to being constructed or eroded by political institutions and choices." As Kriesberg (2003a) argues identities are often based on shared values, beliefs and concerns (i.e.,. religious beliefs or political ideologies, attachments or practices) which are open to attainment by choice, not ascribed traits. This explanation is preferred here, although it is recognised that some ethnicity traits cannot easily be modified by social processes.

\section{The breakup of the Former Yugoslavia}

Once a conflict has descended into violence, people forgot that group relations may have been significantly more sociable and peaceful. The break-up of Yugoslavia to test the thesis that natural hatreds, hostility and intolerance are causal factors in ethnically based group wars. The allusions to ancient hatreds were the primary factor explaining the conflict's barbarity. The inhumanity was characterised by "weekend warriors" and paramilitaries, ${ }^{25}$ neighbours fighting against neighbours, and the targeting of civilians and a state policy of ethnic cleansing. Group relations post-WWII, however, were characterised by high levels of accommodation, contact, and trust. As a state created in the aftermath of WWI, intermarriage was low between the groups later party to the Bosnian conflict (Smits 2010), however, intermarriage in $\mathrm{BiH}$ was significantly higher than elsewhere in Yugoslavia and accepted - 16.7\% in 1981 (see Hodson et al. 1994). Across the board, ethnic relations were cooperative and neighbourly. All sorts of people went about transacting normal relations without thought to nationality including

2583 paramilitaries operated in Bosnia between June 1991 and late 1993 - 53 Serbian (c. 20,000-40,000 members), 13 Croatian (c.12,000-20,000) and 14 Bosniak (c. 4,000-6,000). 10 to 20 per cent of adult males in militias, added to the military and police, are more than enough for death and destruction against civilians on a massive scale. See: United Nations Security Council, 'Final Report of the Commission of Experts Established Pursuant to Security Council Resolution 780', (New York: United Nations S/1994/674, 1994b). 
colleagues and workers, school pupils and teammates. Some were not interested in bothering to know another's nationality. People holidayed in the different Republics. Significantly as Sekulić et al's (2006: 800): study revealed:

There is no evidence of urban violence between ethnic groups, ethnic ghettoization, or interethnic village confrontations during Tito's years - events that the communists could not have held in absolute check in the face of longstanding ethnic hatreds. There was no need to dispatch police or military forces to prevent confrontations between ethnic groups. There was no indication of communal violence such as that characterising Muslim-Hindu relations in India or Catholic-Protestant relations in Northern Ireland. There was no outburst of fighting or hostility similar to the attacks on Chinese minorities in many Southeast Asian countries or even anti-immigrant outbursts (e.g., against Muslims in Croatia or Croatians in Slovenia) similar to those in contemporary Western Europe. In spite of the deadly relations during World War II, relations were largely cooperative and peaceful in the following four decades.

Oberschall (2000: 982) argues that: "Yugoslavs possessed two ethnic frames in their minds, an ethnic cooperation and peace frame for normal times, and a crisis frame anchored in World War II memories." The ethnic groups (encompassing the six republics of $\mathrm{BiH}$, Croatia, Serbia, Macedonia, Montenegro and Slovenia and of two autonomous provinces Kosovo and Vojvodina) felt collective pride in having resisted the might of the Soviet Union in 1948 and in their new economic system. A generation later, fuelled by power struggles following Tito's death in May 1980 most people in Yugoslavia felt that their identities as Serbs, Croats, Slovenes, Muslims, or Bosniaks were what defined them, not their identity as Yugoslavs.

Primordial interpretations of this case argue that innate hatreds continued to simmer under the surface and were paused by 45 years of communism. On closer examination this fails to hold true. However the myth of ancient hatreds as promulgated by Kaplan (1993) in his book Balkan Ghosts, was accepted by politicians including President Bill Clinton and Prime Minister John Major. ${ }^{26}$

\footnotetext{
${ }^{26}$ Like Kaplan, Dijlas writing on WWII stated "the hatred between the Orthodox and the Moslems in these parts is primeval. Milovan Djilas, Wartime, trans. Michael B Petrovich (New York and London: Harcourt Brace Jovanovich, 1977).
} 


\section{Rwanda - constructed ethnicity}

There is nothing intrinsically ethnic in these conflicts. Relegating all conflicts into a single box is dangerous. There are very few cases of purely ethnic conflict with mass eruptions of ethnic antagonism - not in $\mathrm{BiH}$ - nor Rwanda either.

Unlike the Nazi killings, the Rwandan genocide was not an industrial process but one where a large chunk of the Hutu population participated in massacring their neighbours in and around their homes and churches. "The children did not cry, because they knew us... They made big eyes. We killed too many to count," said Juliana Mukankwaya, explaining why she and other women in her village rounded up the two children of her Tutsi neighbours and bludgeoned them to death (as quoted in Gupta 2001: 3). She rationalised that death for these children, whom she had known since birth, was preferable to the harder life they would face parentless in civil war after their father had been slaughtered in front of them, and their mother dragged away.

The existence of antagonistic ethnic relations does not explain why people did this. In Rwanda, the Hutu and Tutsi were physically one group in terms of language (Kinyarwanda), religious and philosophical beliefs and customs but became diverse imagined communities. The weakening of social relations and the invention of tribalism are a consequence of the colonial era, where the Belgians' brutal administration practices institutionalised the superiority of the Tutsi through systematic discrimination.

While the Tutsi were traditionally the owners of cattle, ethnic hatred did not exist between the 'groups' in precolonial times. ${ }^{27}$ Any distinctions then were simply about occupation and class, but membership was not necessarily static (Prunier 1997). Although differences between the groups therefore existed, it was not until Europeans arrived that they became significant. Tutsi were preferred first by the German colonial administration at the turn of the 20th century, and after WWI, by the Belgians, for appointment to administrative or military posts, as well as educational opportunities. The Belgians paved the way for future conflict in Rwanda by guaranteeing the monopoly over power. The minority Tutsi

\footnotetext{
${ }^{27}$ For more on this period of Rwandan history see: Gerard Prunier, The Rwanda Crisis: History of Genocide (New York: Columbia University Press, 1997) at Chapter 1, Mahmood Mamdani, When Victims Become Killers: Colonialism, Nativism, and the Genocide in Rwanda (New Jersey: Princeton University Press, 2001) at Chapter 3.
} 
"overrule" of the majority Hutu became harsh and created a sense of collective Hutu identity. While colonisation entrenched socio-economic disparities, the division of groups along "ethnic" lines occurred through colonial mythology packaged in Europe and disseminated in Rwandan schools which devised a history conforming to the thenfashionable theory that a superior "Caucasoid" race from northeastern Africa - in this case, the Tutsi - had arrived in Rwanda. Using their political and military abilities to conquer the far more numerous but supposedly "less intelligent" Hutu, they were in effect responsible for all signs of true civilisation in "black" Africa (Colletta and Cullen: 37; Forges 1999: 34-35). From 1926, a census forced all Rwandans to record their ethnic identity. Identity cards were issued by the state proclaiming the holder's race. The education system was segregated, and Hutu were not allowed to join the priesthood or government.

By the 1950s colonial attitudes to the Hutu softened, mainly at the behest of the Catholic Church and UN pressure. However, better access to political and socio-economic system left the ruling minority Tutsi fearful of a majority uprising and ethnic politics intensified. During the 1959 pre-independence struggle, a social revolution occurred in which the Party for the Emancipation of the Hutu People overthrew the Tutsi leadership, ironically with the help of Belgian forces. Violence between the groups spread and many Tutsi became refugees in neighbouring countries. On independence in 1962, the new Hutu extremist elite purged Tutsi from government and the army. The Tutsi were further marginalised when the traditional social and political systems (warrior class) being replaced by the central administration of the state.

Tutsi rebel groups in Tanzania, Uganda, Burundi and the former Zaire, began violent incursions into Rwanda initiating further conflict, more Tutsi out-migration and repression of Tutsi from the central government - a pattern which continued over the next thirty years. Interestingly intermarriage between the groups increased in the decades following the revolution but with the creation of a one-party state the economy declined and many demanded reform. In October 1990, Tutsi rebel forces of the Rwandese Patriotic Front (RPF) invaded northern Rwanda, precipitating the arming of local officials by Rwandan security forces, the expansion of the national army and the rounding up of Tutsi accused of collaborating with the rebels on the basis of their ethnicity. The Hutu political elite played upon memories of the past to disseminate messages of hate directly 
to a large audience through the media. Even as evidence of human rights' abuses mounted, many international actors on the ground were hesitant to point the finger at the government (Forges 1999). ${ }^{28}$ By the end of 1993, preparations for violence continued to take place in full view of UN peacekeepers. On April 6 1994, President Habyarimana died when his plane was shot down over the capital of Kigali. The defence forces immediately attacked Tutsi and pro-peace Hutu. Madness gripped the country. A campaign of Tutsi elimination ensued with speed. It is estimated that 800,000 Rwandans died within a three-month period at the hands of their brethren - more than any other mass slaughter in recorded history.

More accurate examples of purely ethnic conflict are the nationalist rejections of alien, minority or foreign rule such as occurred in apartheid South Africa and elsewhere. However, even these struggles had complex histories (i.e. Rhodesia/Zimbabwe, Vietnam, and Afghanistan after the Soviet invasion). It is not as simple as the states with ethnic minorities being more prone to conflict than others. There are fewer than twenty states that are ethnically homogeneous (ethnic minorities account for less than five percent of the population), including Japan and Sweden, who have had a uniform composition for some time. The population transfers and genocide that took place during WWII and the way borders were redrawn at war's end, created further states with few minorities Poland, Hungary and the Czech Republic. However, ethnic homogeneity is no guarantee of harmony. Critics point to Somalia, the most ethnically homogeneous state in subSaharan Africa which has been torn apart by clan warfare and competition for power. Explanations are more complicated; ethnic groups can be formed over time by processes of administrative classification, political mobilisation and socialisation.

\section{ii) Shapers of group identity - human needs and collective fears}

Strong, even extreme, attachments to ethnic, religious, national and clan identities have appeared to push individuals and groups to engage in inhumane and improbable acts

\footnotetext{
28 Unhappy Rwandan activists approached international human rights organisations to create a joint commission on the situation in Rwanda. Subsequent inquiry showed that Habyarimana and his group were responsible for massacres of Tutsi and others in opposition to them. See: International Commission of Investigation on Human Rights Violations in Rwanda, 'Report of the International Commission of Investigation on Human Rights Violations in Rwanda since October 1, 1990 ', (Joint Publication: Human Rights Watch (New York), the International Federation of Human Rights Leagues (Paris), the International Center for Human Rights and Democratic Development (Montreal) and the Interafrican Union of Human and Peoples' Rights (Ouagadougou) 1993).
} 
towards those perceived to be the enemy. The basis for groupism is widely assumed to concern human needs. As Guetzkow (1957: 47) said in 1957: “Groups, in general, are organised to meet human needs, their structures and processes are in part moulded by these needs". Burton (1987) argues that identity groups will do almost anything to fulfil their needs and that grievance develops from needs' deprivation, which is often relative. These go beyond basics such a food, shelter, water, personal safety and well-being to encompassing psychological needs - identity recognition, security, autonomy, distributive justice, etc. These seemingly individual needs are articulated through identity groups. As Druckman (1994: 44-45) expands:

\begin{abstract}
Much of social behaviour appears to be motivated by the need for affiliation (affective involvement), the need for achievement (goal involvement) and the need for power (ego involvement). Groups function because they are attractive to members (affective involvement), accomplish things and solve problems (goal involvement) and provide status for the members (ego involvement).
\end{abstract}

Needs are held as non-negotiable, and for that reason any pressured settlement will only bring about a short-term ceasefire. Observers accept that reactions to coercion are culturally variable, and that needs are understood and satisfied differently (Kelley 1973). From Azar's work (1990: 10-11), the importance agreed governance are apparent. In terms of the state for example - it has been "endowed with authority to govern and use force where necessary to regulate society, to protect citizens, and to provide collective goods". It is the state's role that satisfies or frustrates individual and identity group needs and governance that can build civic nationalism and bring people together. ${ }^{29}$ Needs such as security and recognition, are not zero-sum in that one party need not gain at the expense of another.

Therefore post-Cold War ethnic conflict - rather than being the result of ancient hatreds or the sudden 'uncorking' of Soviet repression - are most often caused by "collective fears of the future", the denial of the "needs" and chauvinistic behaviour that can by

\footnotetext{
${ }^{29}$ Azar died before the Cold War and the collapse of that world order. Other literature has built upon this, referring to the problem as a "crisis of governance". See: Stephan Van Evera, 'Hypotheses on Nationalism and War', International Security, 18/4 (1994), 5-39, Erhard Eppler and Herfried Munkler, "New Wars" Discourse in Germany', Journal of Peace Research, 41/1 (2004), 107-17. Robert H Jackson, Quasi-States: Sovereignty, International Relations and the Third World (Cambridge: Cambridge University Press, 1990). Mohammed Ayoob, The Third World Security Predicament: State Making, Regional Conflict and the International System (Boulder: Lynne Rienner, 1995).
} 
magnified by political memories and emotions (Evera 1994; Lake and Rothchild 1996). The emotion that poisons ethnic relations is fear, particularly as violence worsens (see Lake and Rothchild 1996; Sekulic et al. 2006). Fear could concern group extinction, assimilation into or domination by another group, one's life and property, or of being a victim again. Hate follows fear where the threatening others are demonised and dehumanised. In Yugoslavia, the means of igniting and spreading fear was through the news media, politics, education, popular culture, literature, history and the arts. And once mobilised, they become the focus of collective action within society.

\section{iii) Collective madness}

The darker side of collective identity is the feeling of the enemy. As myth-making animals, humans create what Jung (1959) calls "archetypes" - vilifying and depersonalising evil ones - and ultimately denying them humanity. We are more compassionate to living things that resemble us. We, therefore, dehumanise in war and conflict to lift humans from deep inhibitions to overcome an aversion to harming humans (Eibl-Eibesfeldt 1979). Dehumanisation enforces "us" and "them" identities and inspires fear and repugnance. As Hume (2007: 225) observed in 1739, in what is perhaps the first published observation of dehumanisation in war:

\footnotetext{
When our own nation is at war with any other, we detest them under the character of cruel, perfidious, unjust and violent: but always esteem ourselves and allies equitable, moderate, and merciful. If the general of our enemies be successful, it is with difficulty we allow him the figure and character of a man.
}

This can be seen in the racist literature of the adherents of slavery, in the formation of hate groups all over the world, in Menachem Begin's epithet for his Palestinian enemies: "beast walking on two legs" (Holmes 1985: 368; Kapeliouk 1982) and in the warnings to the Tutsi played on Hutu-controlled Radio Télévision Libre des Mille Collines: "You cockroaches must know that you are made of flesh! We won't let you kill. We will kill you". Depictions of subhuman beasts or parasites, rats or another kind of vermin needing eradication, are common. As is the idea of dirt, vermin or disease requiring society to be decontaminated. Wiesel's Night (1982) and Levi's If This Is Man (1987) document the stages of dehumanisation the Jews experienced in concentration camps. They were physically stripped, numbers tattooed on them to eliminate the need for individual names, human relations were cancelled and so on. Another technique employed by those seeking 
to dehumanise others is to displace responsibility for one's actions onto a spiritual or secular authority (Roscoe 2007). Although all this seems irrational, the mind is organised in modular fashion which allows for the possibility of conflict between its components. It is possible that one part of the mind can withhold information from the other (D. L. Smith 2007: 113). In situations where a strong "them" exists, a kind of collective madness can arise.

In this respect, state breakdown and associated anarchy and security issues cause groups to arm, much like the arms race at the interstate level. Other forms of "trauma" - as in shock felt by a large percentage of the population - could include political assassination, economic depression or feelings of severe relative deprivation, unprovoked acts of war (or terrorism), or some form of disaster. Any of these events can trigger a dramatic change in collective mental states, either directly, or through incremental accretion that can be transmitted by contagion (Bostock 2010). In societies with many overlapping identities free from real or perceived wounds, a strong sense of coherence (social capital) and recognition (psychic capital) ${ }^{30}$ there will be plenty of immunity against contagious fear and resistance against chauvinistic leaders who prescribe violence against "enemies" as a solution. While explanations of collective madness usually focus on the coalescing of such factors - rule of law breakdown, failure of power sharing democracy, absence of intervention, and certain kinds of leadership - it is the presence of psychological preconditions which forms collective mental states with which other factors, such as manipulative leadership, interact. This is not due to ethnic hatred, but fear and insecurity. ${ }^{31}$ In the Yugoslav crisis, Ignatieff (1993: 42) puts it thus:

Once the Yugoslav communist state began to split into its constituent national particles the key question soon became: will the local Croat policeman protect me if I am a Serb?

\footnotetext{
${ }^{30}$ As opposed to psychic numbing: "general category of diminished capacity or inclination to feel." See: Robert Jay Lifton, The Nazi Doctors: Medical Killing and the Psychology of Genocide (New York: Basic Books, 1986) at 442. Coherence is a feeling of confidence in one's internal and external environments, the opposite of collective paranoia. The importance of memories of pleasure, success, achievement, recognition, what Boulding refers to as "psychic capital", arguably relates to the fulfilment of basic human needs. Kenneth Boulding, A Reconstruction of Economics (New York and London: Wiley, and Chapman and Hall, 1950).

${ }^{31}$ The classic example of this interaction is Hitler and Germany. As Langer wrote, it "was not only Hitler, the madman, who created German madness, but German madness that created Hitler". Walter C. Langer, The Mind of Adolf Hitler. (London: Secker and Warburg, 1973) at 138. The explanations given for the psychological preconditions giving rise to Hitler include Germany's defeat in WWI and the Treaty of Versailles' harsh terms, compounded by the Great Depression of 1929 and distorted by the belief that defeat was caused by communists, republicans and Jews.
} 
Will I keep my job in the soap factory if my new boss is a Serb or a Muslim? The answer to this question was no, because no state remained to enforce the old ethnic bargain.

All states are at risk of collective madness, but a well-adjusted, collective, mental state provides some immunity from violent conflict. However when this "state" is disordered, individuals can offer themselves as saviours. Power is consolidated and their intentions translated into actions, particularly through fear and panic. Most studies of organised violence do not attribute all causality to leadership. There must be a facilitating fellowship or at least acquiescent bystanders (Staub 1992), and very likely a situation where the "raw material" of collective grievances are present. These disturbances may already exist in large measure or be augmented from small beginnings. Such patterns were common features in the early stages of the Third Reich, the Cambodian and the Rwandan genocides and the break-up of Yugoslavia.

\section{iv) Victimhood}

Many analysts single out the discourse of victimisation and victimhood as one used extensively by the groups in the Balkans region (ie. Mai 2001). Being a victim provides a kind of moral authority, a sense that one deserves to be treated specially. In fact, being a victim is so powerful that we would expect people to assume victim status if they can, as victimhood gives us the right to take action against our enemies while blaming them for violence at the same time (Searle-White 2001: 92). As Denitch (2000) explains:

In the distorted pictures which I observed in Yugoslavia each party consistently presented itself as a victim and the Other as a threat or a potential threat. None of the parties reacted to the Other directly but to its own projections of the Other.

\section{Example 1: Battle of Kosovo and WWII grievances}

Sometimes victimhood is deliberately misused to justify war against other groups. Slobodan Milošević regime's systematically represented Serbs as victims in Croatia, BiH and Kosovo (Silber and Little 1996). A polarising incidenct concerned the commemorations of the 600th anniversary of the Battle of Kosovo (5 June 1389) at the very battlefield (Gazimestan) where Serbs had lost and been enslaved by the invading Turkish army of the Ottoman empire. This occurred against a backdrop of ethnic tension 
between Kosovo's minority $\operatorname{Serb}^{32}$ and majority Albanian population, caused partly by the pushing through of a new constitution which reduced the autonomy of Kosovo. This led to a demonstration in which many Albanians were killed by Serbian security forces, and also political tensions between Serbia and the other republics of Yugoslavia. During Milošević's (1989) speech to an audience of roughly a million people, the first allusion to the possibility of future armed violence and of Serb victimhood was heard:

Serbs have never in the whole of their history conquered and exploited others. Their national and historical being has been liberational throughout the whole of history and through two world wars, as it is today. They liberated themselves and when they could they also helped others to liberate themselves.

His speech was the climax of many months of events looking at the "betrayal of Serbia" and public "rallies for truth" to show Serbs outside of Kosovo the reality for Kosovo Serbs. Even the 600 year old remains of the Serbian battle leader, Prince Lazar, were paraded around Serb inhabited areas of Yugoslavia. As Petrovic (2000: 170) observes, Milošević sought to combine "history, memory and continuity", promoting the illusion that those who had fought and lost in 1389 were the same as those fighting for Serbian national survival in the present.

In his closing remarks, Milošević turned to relations between Serbia and the rest of Europe. He portrayed medieval Serbia as not just the defender of its own territory, but of all Europe in the fight against the Ottoman Turks. Orientalism - Muslims as an "other" (accusing Bosnian Muslims of wanting a state based on Sharia law, Serbian women for their harems and viziers or ministers to rule the country) - was contrasted against Europeanisation: "to the values of Europe, meaning to Christianity, to modernity, to Civilisation with a capital C" (Vetlesen 2005: 153), echoing Huntington's polarisation of the West against Islam. ${ }^{33}$

\footnotetext{
32 The Albanian birthrate was high and combined with Serb out-migration Kosovo changed from 23 per cent Serb in 1971 to 10 percent by 1989. Serb nationalists accuse Albanians of threatening them with violence and the police and judiciary of not protecting them. Accusations sexual assault and rape by Albanians against Serbs were reported in the media and widely believed by Serbs even though there is no evidence to suggest that this was true.

${ }^{33}$ No other political theory has been given warmer reception and greater prominence in Serbia than the clash of civilisations. It provided Serbian propaganda with a degree of academic respectability and legitimacy as the conflicts of the 1990s in former Yugoslavia had been in Serbian defence of the values of (Western) civilisation against its enemies. See Dmitry Pozhidaev, 'What Statements Do Not State', Journal of Language and Politics, 6/3 (2007), 327-49.
} 
Victimhood was invoked in the memory of the bloodbath carried out by the fascist Croat forces (Ustashe) in the early 1940s in which many Serbs had lost family. Stories were recited of the Croat-run concentration camp at Jasenovac where a large number of Serbs were killed, ${ }^{34}$ of massacres of Serbs such as at Omarska (later a notorious Serb-run concentration camp), and anecdotes about Ante Pavelic, the Croatian Nazi-puppet dictator. ${ }^{35}$ As Danner (2009: 208) explains: "effective propaganda must have within it a kernel of truth." In the blame game, something that happened 2,000 years ago can be as relevant as an event that took place 50 years ago or just the other day. Milan Kovačević, the former deputy mayor of Prijedor, who helped establish and operate the Omarska camp where Croats and Muslims were put to death in 1992, justified it as payback for Jasenovac where he was interned as a child. However he denied Omarska was at the same level i.e. a death factory (Roger Cohen 1998: 479):

\begin{abstract}
...Memories cannot be destroyed. Many Serbs know, intimately, who slaughtered their grandfathers. Clinton knows the Dayton Accords, he knows they are good for him, but I doubt that he understands us. This part of the world is like a wind tunnel: the gusts that come through it are uncontrollable...

...There is a direct connection between Jasenovac and Omarska. During World War II, the Croat and Muslims killed us; this time, it was the other way round, we killed them. Perhaps in fifty years it will happen again, to us.
\end{abstract}

There may well have been collective memories, but these had to be opened and activated and directed by chauvinistic goals. Nationalists such as Milošević, Tudjman did not invent the crisis frame. They did, however, activate and amplify it assisted by the space created by the already weakened state. Burg (in Sisk 1996: 39) concludes, “. . . interregional conflicts were precluded in [Yugoslavia] . . . by the actions of determined secessionists, not by the presence of spontaneous hatreds at the mass level.'

Instead of primordial explanations for why groups conflict, nationalists or chauvinists activate and amplify what Oberschall (2000) calls the "crisis frame". Ethnic manipulation is possible because of a cognitive frame. This concerns a "mental structure" placing and

\footnotetext{
34 There are no official statistics on the casualties and huge debate has reigned: perhaps c50.000 Serbs, but also Jews, Gypsies, anti-Fascist Croats and various others.

${ }^{35}$ Similar claims were made about the Bleiburg massacres (May 1945) where Croatian soldiers and civilians were killed in fleeing from the defeated Independent State of Croatia, a puppet state of the Nazi regime.
} 
linking people, groups and events into a narrative that can be communicated and shared with others (Snow et al. 1986).

\section{POWER SHARING}

In marrying elements of human nature and groupism together, peace-building literature and practice have attempted to incentivise groups to join together in governance with guarantees that they will not be excluded from politics in the paused-conflict polity. There are two main theoretical views on how to accommodate conflicting groups, primarily ethnic, through power sharing - the consociational approach of Lijphart (1977, 1985, $1990,1999)$ and the integrated approach of Horowitz $(1985,1990){ }^{36}$

Lijphart's theory is based on the premise that it is impossible to erase the distinctions between groups once they appear. Sometimes factors like a common enemy unite groups, but this is short-lived. If the conflict involved differences between groups, then the state must be built around these ethnic differences. Ethnic groups should, therefore, be kept apart and institutional power divided between them. Fearon \& Laitin (2000: 849) have argued, consociation "border[s] on primordialism as they assume unchanging and unchangeable ethnic identities". Lijphart does not favour state partition or secession. Instead, state structures should be adjusted to accommodate most of the ethnic groups' interests to afford them equal influence on the decision-making process and governance. Four characteristics define this approach: participation of the representatives of all significant groups in government (a grand coalition); a high degree of autonomy of the groups; proportionality; and minority veto (Lijphart 1990: 494). Lijphart's recommendations are based on his reading of political practices in several European states (Belgium and Netherlands) and established conditions conducive to consociational democracy such as territorial loyalties, a handful of political parties and the some crosscutting cleavages. Proportional representation systems are therefore the electoral system favoured by consociationalism, as well as parliamentary systems and decision-making

\footnotetext{
${ }^{36}$ Both approaches have been built upon, for instance see: Peter Harris and Benjamin Reilly (eds.), Democracy in Deep- Rooted Conflict: Options for Negotiations (Stockholm: International IDEA, 1998), Timothy Sisk, Power Sharing and International Mediation in Ethnic Conflicts (Washington D.C.: United States Institute of Peace, 1996).
} 
procedures that require concurrent and/or qualified majorities. Later, in defence of the theory's assumptions, Lijphart (2002) focused more on power sharing and autonomy over the "secondary characteristics" of proportionality and minority veto but still maintains that executive power sharing means all significant groups must be represented in political decision making.

Horowitz, on the other hand, believes in an integrated approach. States will not be able to exist peacefully if old divisions are left untouched. The building of inter-group links is crucial, both at the central level and in as many other levels as possible. Co-operation between groups should be encouraged and fostered by political and electoral incentives pre-election, not just rigid institutions requiring groups to work together after an election. Where "ethnically based political parties pervade civilian politics" (Horowitz 1990: 455) - the extreme end of the scale - a peaceful system can still occur provided that there is equal involvement of all in decision-making. Ideally links built between groups should progressively de-ethnicisation politics. Horowitz's "centripetal" recommendations include presidential systems. Consequently Reilly (2006) advocates preferential voting. When used in ethnically heterogeneous districts, such voting practices, it is claimed, have facilitated vote pooling across the ethnic divide, encouraged the emergence of more peace-making political parties, and promoted the formation of resilient inter-group coalitions (Horowitz 1990; B. Reilly 2001). Reilly’s work, particularly in Papua New Guinea (B. Reilly 2006), praised informal power sharing approaches that resulted in political inclusion through deal-making rather than the prescriptions of law. While there is no doubt merit in voluntary accommodation, the limits of this are obvious, for while Papua New Guineans “own” elections - as in they have become part of their culture corruption and game-playing are rife.

The commonality between the two theories, which pertains to any investigation of postconflict peacebuilding, is of state decentralisation which allows groups to enjoy a degree of autonomy. This respective independence has a number of advantages, the feeling of not being dominated by another group being the cardinal one.

The problem with power-sharing mechanisms, as seen in practice, is that ultimately they are elite-driven, thus ignoring the masses of ordinary people who are supposed to switch off their "us and them" mentality. Any new governance compact is not just between 
political groups within the general population and between the general population and those elected to govern. Power sharing is not seen as a means of teaching groups to live together and negotiate over issues on which they disagree but is upheld as a means of stopping violence between groups who are not willing to otherwise stay the course. This tends to create vested interests that can only be modified by consensus which is unlikely if one group refuses to budge. The focus on stability in the short term favours strategies which actually increase instability, and are unlikely to generate loyalty to peace in the long term. Horowitz (1985) essentially is advocating containment of group conflict so that identities do not crystallise as characterised by more severe conflict, rather than eradication or a new consensus. International policy-makers have contributed to the reinforcing of ethnic divisions in states undergoing conflict. Primarily, this is because post-conflict institutions are built on an implicit assumption that ethnic divisions are beyond transformation - an "assumption of intransigence". While the likes of Simonsen (2005), interpret this as working against reducing the significance of groupism strategies that still emphasise identities strengthen their importance. Both these theories are not without their critics, particularly because of the lack of practical evidence that they work. Lijphart's solution, at the extreme end as in the case of BiH addressed in Chapter 5, tends to freeze the conflict in place instead of resolving or indeed transforming it (see for example Paris 1997; Synder 2000).

Roeder and Rothchild's (2005: 6) most recent edited study offers "power dividing" which is seen as: "an overlooked alternative to majoritarian democracy and power sharing". Power sharing, they argue, is only useful in the short-term to overcome commitment problems that may characterise conflict parties in the immediate paused-conflict context agreeing to and sticking with a peace settlement. In the long-term, however, power sharing is detrimental to peace and stability. Instead, they recommend civil liberties: taking powers away from government while those that are left are distributed amongst multiple, cross-cutting majorities, therefore establishing checks and balances through balancing one decision-making centre against another. This kind of consensus approach is based on the arrangements associated with the US constitutional and presidential system and a Madisonian model of federalism which contextually bears a microscopic resemblance to the situation in conflict-torn countries. Perhaps because of these difficulties, Roeder and Rothchild's policy recommendations for international assistance 
include delaying intervention assistance until a 'victor' emerges and holding groups together that want to live together (Roeder and Rothchild 2005: 337-45).

\section{i) Strengthening group strategies}

While the debate between consociationalists and integrationists has raged over the years questioning the value of power sharing as a mechanism to transform conflict in divided societies is scarce. The implication is that there are no absolute answers. Bringing all parties to the conflict together is crucial - in a peace conference for example - but all parties must be locked into the process so that they do not out-chauvinise each other or hold a knife to the throat of the process. ${ }^{37}$ Initial representation by group leaders is fine, but then what? Movement is needed.

Of the few recent examples of scholarship proposing strategies to bind leaders together in governance without forming blocks in the way political parties do, is McGarry and O'Leary's (2004) work on the Northern Ireland conflict. Here they advocate strongly for the use of sequential proportionality rules (d'Hondt or Sainte Laguë) in allocating cabinet positions. Such a mechanism avoids protracted bargaining between groups and increases groups' incentives to remain part of cross-communal coalitions.

The other important dimension is the growing awareness of conflict having regional or global affects. In the case of Northern Ireland, the fact that cross-border institutions formalised cooperation with the independent Irish (republic) government and renewed inter-governmental cooperation between the British and Irish, provided regional cooperation $^{38}$ on the issue and an acknowledgement that if the majority of Northern Ireland and Ireland wanted a united Ireland, then this right would be acknowledged. The signatory parties committed themselves to respecting the outcome of future referenda on this issue. Self-determination disputes are obviously central to a range of conflicts as highlighted by Kosovo most recently. In these cases, the issues at stake are not simply about sharing power, or even primarily about sharing power. Questions of autonomy,

\footnotetext{
${ }^{37}$ A November 2010 example of this is the inability of the Iraqi parliament to form seven months after elections because the Kurds with their 57 seats refused to join either of the two sides which need their support.

${ }^{38}$ Institutions of cross-border cooperation have been utilised elsewhere, in South Tyrol for example, and also in less conflict prone situations such as the arrangements surrounding the European Union.
} 
sovereignty, acquisition, symbols, explicit recognition as national communities and institutional links across state frontiers are also crucial.

Consociations have been accused of entrenching and institutionalising pre-existing groups and deincentivising group elites to change. Horowitz (1985: 566-76). McGarry, O'Leary (2007) and Lijphart responded to this by attempting to move theory away from the corporate model of power sharing towards a liberal model. Here, groups that emerge during democratic elections would be recognised regardless of what they are based upon. Examples in the real world - such as BiH, Northern Ireland, Lebanon, Cypus - follow the corporate model. Finally, instead of an emphasis on grand coalitions, joint consent across significant communities is needed so that elites are not governing with factional or lower levels of support from their own segments. This would exclude just any coalition or indeed the cooptation of unrepresentative minority leaders.

For the purpose of this research, the approach of Simonsen is preferred because it captures many elements of conflict transformation theory and the malleability of groupism. Instead of an assumption of intransigence, Simonson (2004) argues for a spectrum of processes to promote common interests and loyalty to universal institutions. ${ }^{39}$ As he argues: "this span of processes is not one that signifies an alteration of the character of existing ethnic (or group) identities - which, if successful, would eventually lead to ethnic reidentification (assimilation) - but rather could be described as de-ethnicising politics, making ethnicity less salient" (2004: 290) While he does not offer any strategies outside of those already discussed this vein of thinking is also seen in the argument of the International Crisis Group (2003a) against the applicability of consociationalism in Kosovo. Risk factors are identified as the minority's small share of the population, a lack of internalised human rights culture, and immature political structures unable to accommodate the mobilisation of minority groups. Quoting a report by the International Institute for Democracy and Electoral Assistance (International IDEA), the ICG argued that UNMIK: "should wager on a civic future for Kosovo, rather than seek compromises with collectivist ("ethnicist”) political structures for tactical and short-term advantage . .

\footnotetext{
${ }^{39}$ Ironically, the conflict and subsequent peace-building activities may provide the opportunity to develop a broader group identity. Anti-colonialism movements often united groups with very different interests, only for them to fracture after independence. On Bougainville however, war and peace-building served to unify. What it means to be a Bougainvillean is therefore a relatively new concept. See Sean Dorney, The Sandline Affair (Sydney: ABC Enterprises, 1998) at 39.
} 
. it is impossible to build a multi-ethnic Kosovo by directly implementing multi-ethnic policies" (International Crisis Group 2003a: 17). The difference between pre-determined groups and the self-determined groups of the liberal consociational model for elections seems to be wishful thinking given the mindset of identity groups in the lead up to elections without alternative strategies and learned constitutionalism.

Conflict, however, is not solely attributable to tangible interests and breakdown of institutional order. The identity literature canvassed above clearly shows that psychological dimensions must be addressed in terms of the relationship between individuals, groups and governance structures. Socially constructed identities are another layer of complexity that must be broken down, requiring not just political settlement strategies but also reconciliation (Kaufman 2006; Long and Brecke 2003: 28-31). Intangibles like myths and fears make intrastate group wars intractable leading to security dilemmas between groups and to symbolic chauvinistic politics where compromise seems like a betrayal. Policy tools to encourage changes in attitudes and social practices concern groups abandoning provocative rhetoric but also explicitly acknowledging each side's own responsibility and the other side's wounds. Other initiatives include public education efforts, media campaign, evocative ceremonies, and referenda - even on the future, and problem-solving workshops. An example of the latter is that pioneered by psychologist Kelman (1992), where people from opposing sides of the conflict are brought together to conquer misinformation, hostility and fear. Human rights' mechanisms can grow out of this, and minimise the capacity to define "the other", just as human rights' standards emerged from suffering in WWII. ${ }^{40}$ But they have to mean something, be a road map to any culture's history, not just be forced upon groups and on states.

De-ethnicising politics will not occur if public discussions about groupism are taboo. As will be addressed further in Chapter 6, dealing with the past is important, and this is the only strategy that will stop divisions in society being re-emphasised. Current research coming out of Rwanda suggests that the focus is still on a single identity (Hilker 2009). Thinking back to Sen's critique of the reductionist view which explains the continued

\footnotetext{
${ }^{40}$ Universal Declaration of Human Rights 1948; International Covenant on Civil and Political Rights 1966; International Convention on the Elimination of All Forms of Racial Discrimination 1966; Convention against Torture 1984; Convention against Genocide, as well as the Geneva Conventions (1864-1949) among others.
} 
production of violence by overlooking people's multiple identities and also the diversity within identity groups. Although unsurprising that Rwandans are still focused on identity given the "ethnic" nature of the violence, what is concerning is the continuing stereotyping narrative in relation to the experience of the conflict. Young people overwhelming attributed victimhood to Tutsi and guilt to all Hutu. Only a few were aware of the complexities of the conflict. It does not appear that Hutus, Tutsis and "mixed" Rwandans have entered into dialogue on the conflict or to examine their constructed identities and experiences and interests that are in common. A potential dangerous cocktail for future conflict is seen in the continuing pervasive sense of insecurity about the identity of others and the ongoing reinforcing of difference in "ethnic" stereotyping.

Long and Brecke's (2003) study of ten cases of civil war settlements included seven successes (Argentina, Uruguay, Chile, El Salvador, Mozambique, South Africa and Honduras), not all concerned "ethnic" identity war but all with awful violence and group dynamics. In all examples four desiderata of forgiveness were present - public truth telling, partial justice (focus on most egregious offences), the redefinition of social identities and a call for new relationships: the "forgiveness model". Nationalist discourses must be reconstructed to emphasise that which justifies peace and reconciliation, silencing or muffling the discourses and symbolisigm that fuel fear. At the same time, dialogue and institutions must foster cooperation in solutions to mutual problems and in turn help build positive images and attitudes toward the other group. Little research on the impact of reconciliation exists, but it represents a useful addition to the toolbox (Kaufman 2006) and also to handling spoiler problems identified in the next chapter.

\section{v. CONCLUSION}

Understanding human nature and identity have huge salience for paused-conflict governance. While there might not be defined differences to outsiders, there will be an "us" and "them". The breakdown in public power is almost secondary to this. Without groups being willing to come together for governance, all else will fail. The tools of democracy, where they are capable of being used from the outset, will be exploited, and war by other means will continue. 
It is of little use to proclaim the existence of a state if that state's potential citizens see themselves in the first instance as members of groups or local loyalty systems, which are not so close to governance that they perceive themselves as participating. Power-sharing arrangements in this regard may reinforce division and difference.

It is the gradual internalising of new patterns of social identification, which, in this respect, constitutes the advance of any governance strategy. Establishing a "we" or a mutual perception of belonging in the reinforcing of shared interests, commonality and the provision of security may contribute towards the growth of alternative identities that can promote larger groups to come together around governance. These conflicts can take time and sometimes all it takes is a few extremists or spoilers to derail the progress. Where the norm has become something else it is difficult to reverse; however the malleability of political culture offers the potential for peace. Paused-conflict governance is as much about ideas and psychology as is it is about political institutions. In this respect, the focus at the political level should be less on traditional power-sharing mechanisms past the initially crucial requirement to have buy-in from all groups in the peace process, and rather on developing forward movement - the allocation of power portfolios using the d'Hondt method for example, binds leaders together without the formation of blocks.

For a paused conflict society, building new identities based on agreed rules of the game is required, not employing strategies that cement existing identities or polarise grievance. Through understanding groupism, combined with the necessary exhaustion which will be explained next, the foundational building blocks are laid through which the Leviathan could pacify. 


\section{5: Receptivity - turning to other strategies when war/violence becomes more "tiring."}

\section{RECEPTIVITY, AN INTRODUCTION}

Towards the end of the 1980s, nuclear war was still a distinct possibility. Then the Soviet Union collapsed bringing the Cold War peacefully to an end. In 1994, South Africa's apartheid era ended without significant violence. It would seem that if the capacity for war is genetic, then so too is the capacity for peace. However it is not necessarily for moral reasons that violent conflict has lessened, particularly in the developed world, but that violent conflict has declined as the result of receptivity to alternative peaceful strategies; to learning and ultimately to accepting rules for governance. This comes about through a mixture of experience and tiring and the evolution of mechanisms flexible enough to survive the residual conflict.

The purpose of this chapter is to illustrate how conflicting groups move from being violence-minded to pursuing alternative strategies. This receptivity does not in itself guarantee the pacification of the Leviathan. Receptivity can, however, create a platform for change where there is a true mind shift away from violence towards positive peace. This occurs when there are sufficient consensus and appropriate approaches to sideline spoilers. Where the parties to the conflict are not receptive in this sense, it may well be that frustration will continue, violence spark or chauvinism return. Those who continue to fight in the mind (i.e. focus exclusively on singular identity) are examples of false receptivity, causing groups to retreat to their previous positions, albeit without arms and this must be recognised and carefully managed. However, where the peace-inclined exceed those that are simply too aggrieved to renounce violence (or indeed who benefit from the continuation of conflict), the ground is paved for the renegotiation of the rules for governance based on agreed learning - the theory of the next chapter. 
At the internal state level, the assumption of the complete resolution of social conflict is ahistoric but mechanisms flexible enough to survive have created pacified spaces in a number of countries where receptiveness came first. Receptivity is more than the idea war weariness- that war induces in its participants an inhibition against subsequent war for several years (see O. Holsti and Rosenau 1984; Richardson 1960). Nor is it the same as "mutually hurting stalemates" (Zartman 1985) where neither party to a conflict can overwhelm the other. It also differs from "ripeness" which is explored at length in the conflict literature (e.g. Svensson and Wallensteen 2010: 38). Ripeness is posited as the point when a combination of factors means that the relevant parties accept that it is the right time to resolve the immediate conflict peacefully, often with outside mediation or intervention. Instead, receptivity encompasses a true mind shift from war to non-violent strategies. Groups tire with violence when the pursuit of other strategies either necessitates an end to violence (i.e. for trade) or provides viable alternatives without the costs of violence. Tiring is simply the first stage, an agreement not to do violence, a pattern that has been slowly evolving in a zigzag fashion, more entrenched in some regions than others, since human existence.

There are many examples of tiring without true receptivity. World War I, for example, was called the "war to end all wars" 41 but the further consensus for alternatives to violence was ultimately needed. The League of Nations was created to promote cooperation, peace and security by the triumphant allied powers. A mere two decades later the world embarked on an unparalleled plunge into darkness that devastated Europe with over fifty million deaths. The UN is the manifestation of the allied forces finally saying, "no more state war" and meaning it. This deeply held notion has inextricably become part of the makeup, the very culture, of the West. A larger group identity was established, and rules agreed to - the UN charter being the psychical manifestation of this receptivity.

Even in such positive examples peace needs constant reinforcing and remembering, as a backsliding process can quickly occur.

\footnotetext{
${ }^{41}$ Made famous by then USA President Woodrow Wilson, but probably attributable to author H G Wells as a paraphrase of his 1914 book entitled The War That Will End War.
} 


\section{DECREASING VIOLENCE}

According to anthropologists Keeley (1996) and LeBlanc $(2003,2007)$ death in tribal warfare, based on the proportion of the population at the time, dwarfs that of modern times. If the 20th century's wars had killed the same share of the population that perished in the wars of a typical tribal society, there would have been two billion deaths, not the 50 - 70 million causalities of WWII. While a decade has passed in which Darfur and Iraq occurred, shortly after the century in which Stalin, Hitler, Mao and Pol Pot existed, the claim that violence is diminishing may seem somewhat delusionary. However many and varied studies support the conclusion that violence has declined, albeit in a zigzag fashion, including political scientist Payne's (2004) A History of Force: Exploring the Worldwide Movement Against Habits of Coercion, Bloodshed and Mayhem; as well as the work of philosopher Singer (1981), scholar and journalist Wright (2001), and anthropologist Knauft (1991). Tiring and the acceptance of other strategies (and rules) has caused a gradual shift away from the use of violence in human relationships, dramatically decreasing by the end of the $20^{\text {th }}$ century.

Such a claim is graphically illustrated by homicide rates, particularly in Britain, where the traditional blood feud was criminalised as early as the fifteenth century and the obligations of personal vengeance transferred to the expanding national legal system (Leyton 1997). Looking at violence across an elongated timeframe Gurr (1981: 296) described fourteenth century England as: "a society in which men (but rarely women) were easily provoked to violent anger and were unrestrained in the brutality with which they attacked their opponents". Criminologist Eisner (2003) assembled hundreds of homicide estimates from Western European localities between 1200 and the mid-1990s. In every country analysed, murder rates declined steeply - from 24 homicides per 100,000 Englishmen in the fourteenth century to 0.6 per 100,000 by the early 1960 s. An increase since the 1960s was common though not universal (see Eisner 2008), attributed to "minor perturbation, proportionately no greater than upward swings in homicide rates in Elizabethan times and during the Napoleonic wars - swings which proved to be temporary" (O’Donnell, 2002:56).

Instead, the early modern English ruling elites protected their persons and their estates by the encouragement of what Elias (1994) called the advance of the shame frontier beyond 
personal aggression. This process extended down the social hierarchy and replaced the earlier pleasure in aggressivity with a new set of cultural notions, a new "sensibility" that bracketed violence with fear, embarrassment, and revulsion. From the outlawing of human sacrifice, witch burning, lynching, slavery, vigilantism, duelling, capital punishment, torture and mutilation as routine punishment, rape as a spoil of war came the creation of war crimes, crimes against humanity and genocide. Transgression of these anti-violence norms will occur. Entrenchment will be greater in certain However antiviolence norms play an important role in constraining behaviour. Importantly they also lead to the creation of laws and institutions which then monitoring and enforcement the anti-violence mechanisms. Anti-discrimination laws, for example, have evolved out this.

\section{DEVELOPED-WORLD RECEPTIVITY}

The catalyst for the birth of modern international rules concerning armed conflict, and indeed for the creation of the expansive normative framework constituting contemporary international humanitarian law, was the experience of Swiss businessman Jen-Henri Dunant. Having witnessed the aftermath of the horror of the Battle of Solferino (24 June 1859) where some six thousand died, and almost 40,000 were wounded in just one day of fighting, Dunant reported (1986: 5,11):

\footnotetext{
Here is a hand-to-hand struggle in all its horror and frightfulness; Austrians and Allies trampling each other under foot, killing one another on piles of bleeding corpses, felling their enemies with their rifle butts, crushing skulls, ripping bellies open with sabre and bayonet. No quarter is given; it is a sheer butchery; a struggle between savage beasts, maddened with blood and fury. Even the wounded fight to the last gasp. When they have no weapon left, they seize their enemies by the throat and tear them with their teeth...
}

While not a doctor, his efforts to assist the overwhelming number of wounded, who were dying from lack of care, and the publication of this experience in 1862 led to the creation of the International Committee of the Red Cross and the first Geneva Convention for the Amelioration of the Condition of the Wounded in Armies in the Field (1864). This marked the transformation of something that had been, at best, a practice armies had respected when so inclined into a rule of law. The Hague Conventions of 1899 and 1907 followed, codifying the rules of war. At the end of WWII, and because of it, the Geneva 
Conventions' protections were extended to include, among others, prisoners of war and civilians and so the framework of the UN developed.

People have been searching for strategies to limit violence for much longer. The 1648 Treaty of Westphalia sometimes referred to as the "Peace of Exhaustion", ended the Thirty Years War involving many European countries and can be seen as the first world charter. The creation of a European community of sovereign states was possible only because its members recognised each other as having equal legal standing and guaranteed each other their independence.

However even in the West, killing has not actually been banned outright - self-defence, rules of war, continued defence force reserves, the death penalty, euthanasia. However, rules containing violence have developed. Public attitudes to war since the 20th century stand in stark contrast to past notions that warfare and violence as the means of settling disputes were a normal part of human existence. The distance between the benches in the British Parliament is precisely determined by the length of two swords and one foot and, while each MP's locker still contains a loop of silk on which to hang a sword, members are less able to attack each other and not allowed to cross the mid point during debates the origin of the saying "toe the line" (Richard Cohen 2002: xxii). For governments, war was simply an instrument of statecraft. Force can now only be directly against another state in self-defense or with the sanction of the UN Security Council. Ideologies glorifying violence and war as noble and virtuous endeavours are virtually non-existent today (excluding some terrorist organisations). The hyper-nationalism that drove Nazi Germany and Imperial Japanese is rare.

In terms of war, the EU has at its very core the concept of "never again-ism". The accession process' criteria include compliance with the Charter of Fundamental Rights and the European Convention on Human Rights - which arguably sits at the heart of the new Europe and holds members to a non-violence code. It is virtually inconceivable that France would take up arms against Germany or Greece against Turkey. The embrace of peace is thus an example of conflict transformation theory driving institutional development. 
Within the scholarly community, there is intense debate over the cause of war aversion at the international level - interdependence, monetary cost and increase in international membership - but no coherent theory or real evidence exist to support any of them. Such explanations point to changes likely to enhance security long term, but none accounts for the steep decline in international wars, particularly since the 1980s. The creation of stable nations with effective legal systems and police forces has negated the Hobbesian anarchy of all against all. Eisner (2008) and Elias (1994) see this as the transition from knightly warrior societies to the centralised governments of early modernity. The associated increase in life expectancy has made humans less reckless with their lives and, therefore, less inclined to partake in violence (see also Payne 2002, 2004). Smith (2007) develops this further, arguing that it is not just fear of being killed or wounded that plays a vital role in the desire to escape the horrors of war, but also revulsion. ${ }^{42}$

Pinker (2007) argues that along with cultural changes and changes in attitude, humans have become more interdependent on and empathic towards those outside their immediate tribes or groups, due to globalisation and improvements in technology. Singer (1981) calls this the circle of inclusion, evolution having bequeathed humans a small kernel of empathy, which by default is applied only to a limited group (i.e. friends and relations) but has over the millennia expanded to encompass: the clan, the tribe, the nation, both sexes, other races and even animals. Networks of reciprocity may have pushed out the circle, but so too may have the inexorable logic of the "golden rule": that privileging one's own interests becomes harder when one knows and thinks about other living things (Singer 2002). ${ }^{43}$

Whatever the case, something in modernity has arguably made humans wiser when it comes to violence. Homicide as the primary form of conflict resolution was once an unexceptional feature of life; today it is rare to non-existent in the West and far less

\footnotetext{
${ }^{42}$ For arguments against a simple aggression-warfare explanation and countless examples of avoidance of participation (desertion, mutinies, imprisonment, incapacitation), see: J Mg Van Der Dennen, 'Four Fatal Fallacies in Defense of a Myth: The Aggression-Warfare Linkage', in J Wind and V Reynolds (eds.), Essays in Human Sociobiology, Vol. 2 (Brussels: V.U.B. Study Series, 1986), 43-68, Dave Grossman, On Killing: The Psychological Cost of Learning to Kill in War and Society (Boston; Little Brown, 1995), Barbara Ehrenreich, Blood Rites: Origins and History of the Passions of War (New York: Metropolitan Books., 1997), G Cashman, What Causes War? (Lexington: Lexington Books., 1993).

${ }^{43}$ The rule or code can be found in many philosophies and religion, as far back as antiquity. In the Christian tradition see Leviticus 19:18: telling one to go beyond one's own interests and love thy neighbour as oneself. Some argue that it is more than an ethical code, but the "essence of a universal morality".
} 
common elsewhere than it used to be. Despite residues seen in the activities at Abu Gharib and Guantanamo Bay, when such violence does occur it is usually hidden and widely condemned upon discovery. Exhaustion with violence in industrialised countries has been the critical factor in the decline of international wars. Interdependence and membership of international institutions are a consequence of the peace achieved through war aversion, not its causes (Mueller 2004). However, the different trajectory of civil wars suggests this "worldwide" war aversion is easier explained by what I call developedworld receptivity.

\section{RESIDUAL VIOLENCE AND RULE BREAKING}

Running parallel to developed-world receptivity, violence continues to fester in zones of anarchy such as frontier regions, collapsed empires, unstable states and territories contested by mafias, gangs, and other dealers of contraband.

\section{i) Man's capacity to do violence}

Journalist Danner's (2009) Stripping Bare the Body: Politics, Violence, War documents countries beset by violence: Haiti, $\mathrm{BiH}$ and Croatia in the early 1990s, post-invasion Iraq and recent torture in secret prisons around the world. Having arrived in Haiti in 1986 to cover the country's "transition to democracy" (a popular phrase of the Regan era) after President-for-life, Jean-Claude Duvalier, and his wife were flown into exile on an American plane. Many, including Danner, believed that the elections would change the cycle of violence. Danner quickly realised that (2009: xix):

Violence is the motor of Haiti's politics, the means of regime change, the method of succession. The struggle for power is ongoing and endless, permeating all aspects of life...

The appalling massacre of Haitians, as they set out to vote, by soldiers and the feared Tontons Macoutes militiamen (the paramilitary force of Duvalier and his father who preceded him as ruler from 1957), forced the election to be abandoned. This ushered in Haiti's latest era of instability which in a 25-year period has seen more coups, revolutions, a few elections, an American occupation (not the first), and a dozen rulers. Man's capacity to do evil is clear in the horrific sadism reported in this book - roving security mobs slaughtering civilians in polling places, civilians beating to death suspected sympathisers 
of the former regime, and drunken machete-wielding peasants at road blocks. During the American occupation of the 1990s, no action was taken that would risk American casualties, and therefore militiamen were not disarmed.

Despite being the great "petri dish of foreign aid" (Danner 2010), in Haiti there is no receptiveness to positive peace and the reality of the corrupt state remains unchanged. After the 2009 earthquake, Danner (Ibid) writes:

\footnotetext{
There is nothing mystical in Haiti's pain, no inescapable curse that haunts the land. From independence and before, Haiti's harms have been caused by men, not demons. Act of nature that it was, the earthquake last week was able to kill so many because of the corruption and weakness of the Haitian state, a state built for predation and plunder. Recovery can come only with vital, even heroic, outside help; but such help, no matter how inspiring the generosity it embodies, will do little to restore Haiti unless it addresses, as countless prior interventions built on transports of sympathy have not, the manmade causes that lie beneath the Haitian malady.
}

Moving to the post-Cold War Balkans, on television screens across the world genocide was revealed - soldiers and militias slaughtering civilians, shelling, ethnic cleansing and images of emaciated prisoners peering out from behind barbed wire fences - evoking memories of WWII and outrage. The international community perhaps failed to recognise truely the evil that was being done. The massacre at Srebrenica, for example, was revenge the Muslim inhabitants having used the "safe area" to make nightly raids on surrounding villages, killing Serbs. Many of Srebrenica's men understood this and tried to escape the region (Danner 2009: 261). General Ratko Mladic responded without mercy, massacring two to three times as many Muslims regardless of their individual responsibility for Serb casualties. Compounding this brutality was the death of his father, decades earlier, at the hands of the Ustashe - the Croatian fascist anti-Yugoslav separatist moment and puppet Nazi regime.

Danner's book documents violent conflict, revealing the capacity of individuals to get caught up in violence. Despite the gradual decrease in violence, failure to appreciate mankind's capacity for it risks repetition. The American occupation of Iraq and the torture conducted in CIA secret prisons is clearly linked to the broader depravities Danner documents - from Port-au-Prince to Omarska (the site of a notorious Serb-run 
concentration camp in WWII). The International Committee of the Red Cross report (2007) on compliance with the Geneva Conventions in Iraq revealed that the US had revived long-outlawed torture practices.

Sand's (2008a) indictment of the "fig leaf" legal arguments which distinguished between those who had protection under the Geneva Conventions and those that did not, transpired to be about the desire to interrogate detainees without constraint. Guantanamo became a Geneva-free zone as early as 2002 . The practices used mirror in some respects the UK government's techniques in dealing with the Irish Republican Army (IRA) in the 1970s, including those that culminated in Bloody Sunday. ${ }^{44}$ These actions are widely accepted to have prolonged the conflict by $15-20$ years because of the resentment generated within the community as well as with IRA members and the violence it provoked. The US Senate report (Committee on Armed Services 2008) into the treatment of detainees concluded in a similar vein. Treating detainees harshly reinforced the view that the US was concerned with destroying Islam, increasing resistance to cooperation and creating new enemies.

When photographs of Abu Ghraib's abused prisoners surfaced, protestations of a "few bad apples" were heard from the senior levels of the US government. The reality was found to be quite different (Committee on Armed Services 2008: xxi). However, as shameful as the abuses are, they are mild when compared with many other atrocities in human history. Today we see them as signs of how low our behaviour can sink and should remember why our standards have risen.

The fact that senior government officials, with the help of lawyers in the US Department of Justice, had convinced themselves and others that these practices were legal (B. Woodward 2006) shows that there is no immunity against atavistic vengeance and no junction at which people stop cloaking their baser instincts in the language of justice. Many have denounced these events as the point at which the United States of America (USA) lost "moral authority" (Committee on Armed Services 2008; Malinowski 2008).

\footnotetext{
${ }^{44}$ Bloody Sunday refers to the event of January 30 1972, where during the Northern Ireland Civil Rights Association March in Derry North Ireland, 27 protesters were shot (13 died) by members of the First Battalion of the British Parachute Regiment. The "Saville Report" released in June 2010 concluded that the paratroopers had lost control, shot fleeing civilians and lied to hide their acts.
} 
Crucially however the USA changed the agreed rules; they "reformed" international law unilaterally, the same law that was applied to the world's Miloševićs and Taylors. They not only made the Geneva Conventions not applicable, but they also disregarded the Convention against Torture, the International Covenant on Civil and Political Rights and the UN Charter's prohibition on the use of force.

The Bush administration forgot the lessons of history. Aptly perhaps for a nation so concerned with rules, they simply found lawyers who could be relied upon to give the 'right' legal advice. The large number who understood the reciprocal nature of existing rules was ignored. Sands (2008b) and the International Committee of the Red Cross (2007) documented how US Deputy Assistant Attorney General John Yoo and other highranking administration lawyers helped to design and implement the interrogation policies seen at Guantanamo, Abu Ghraib and secret CIA prisons to which detainees were "disappeared" and tortured. The media "took its eye off the ball" (Sands 2005: 230) and no powerful constituency was publicly willing to defend the rule of law, although of course various NGOs such as Human Right Watch tried. In both the United Kingdom (UK) (who went along with this remaking of the global rules) and the USA, court decisions were needed to correct the illegality of disregarding the Geneva framework, including in the UK the use of "evidence" in court extracted under torture. ${ }^{45}$ The passing of law which provided for the indefinite detention without trial of non-nationals who could not be deported required the UK to derogate from the European Convention on Human Rights, and this was held to be in violation of Britain's international legal obligations by the House of Lords. ${ }^{46}$ Lord Hoffman's judgement illustrates the lesson: (para 97)

The real threat to the life of the nation, in the sense of a people living in accordance with its traditional laws and political values, comes not from terrorism but from laws such as these.

\footnotetext{
45 See Hamdan v. Rumsfeld 548 US. 557 (2006) and A \& Others v. Secretary of State for the Home Department (No. 2) [2005] UKHL 71, [2005] 3 WLR 1249. However, while Iraq may have destroyed President George W Bush and made Barrack Obama possible, it is worth noting that no one has been called to account for instituting a policy of torture, or for changing the rules.

${ }^{46}$ A \& Others $v$ Secretary of State for the Home Department [2004] UKHL 56
} 
Ironically, the US military had themselves drawn up the rules that culminated in the 1947 Nuremberg trial United States of America v. Josef Altstöetter et al, ${ }^{47}$ the only case in which lawyers have been investigated and prosecuted for carrying out professional duties which crossed the line into criminality. Just over half a century later, it transpires that violence directed by the Bush administration had been in plain violation of international rules, but also in plain violation of President Abraham Lincoln's 1863 disposition that the USA does not do cruelty. ${ }^{48}$ There is no difference between those who torture, and those who order the torture and changes to the agreed rules should not be undertaken, in effect, at gunpoint. Spencer Tracy's character, Judge Dan Haywood, in the film Judgment at Nuremberg delivers his final verdict, foreseeing a time when the USA would seek to justify using the means of the enemy, "to rest survival upon what is expedient": 49

How easily it can happen. There are those in our own country too who today speak of the "protection of country" - of "survival". A decision must be made in the life of every nation at the very moment when the grasp of the enemy is at its throat. Then, it seems that the only way to survive is to use the means of the enemy, to rest survival upon what is expedient - to look the other way. Well, the answer to that is "survival as what"? A country isn't a rock. It's not an extension of one's self. It's what it stands for. It's what it stands for when standing for something is the most difficult! Before the people of the world, let it now be noted that here, in our decision, this is what we stand for: justice, truth, and the value of a single human being.

\section{FIGHTING IN THE MIND AND SPOILERS}

Not only can backsliding to violence occur, but receptivity can also be undermined by spoilers. Spoilers are particularly problematic for paused-conflict governance. Where they succeed, the results are devastating. Hutu extremists' rejection of the Arusha Peace Accords in 1994 led to over one million Rwandans dying in less than three months (Melvern 2000). Jonas Savimbi's refusal to accept the outcome of the 1992 UN-

\footnotetext{
47 Trials Of War Criminals Before The Nuremberg Military Tribunals Under Control Council Order No 10: Nuremberg, Oct. 1946-Apr. 1949, 3 (Vol. Iii 1951) (citing US. v. Altstoetter, 3 T.W.C. 1 (1948)

48 General Orders No. 100 to the Armies of the United States in the Field ("General Order"), art 16 (commonly referred to as the Lieber Code of 1863 after Dr Francis Lieber the Professor of Political Science who assisted in drafting them). These rules were later largely codified into international treaty law by the Hague Regulations of 1907.

49 Judgment at Nuremberg (1961, USA)
} 
monitored elections in Angola took the country back into civil war (Stedman 1997). While this thesis is not concerned directly with peace negotiations, spoilers are nevertheless a feature of paused-conflict governance, and the way perceived spoilers are approached early on can impact to varying degrees on Leviathan pacifying. Spoilers will not necessarily destroy peace if robust strategies are adopted with consensus (including internationally) recognising the force of normative power (critical mass) and reinforcing receptivity and tiring. There is no such thing as total peace; a contested peace is likely as various groups and individuals reach a point where learning precipitates trying out new rules. Therefore, toleration must be given to participants in a peace process within reason as they work through their issues - without justifying violent spoiling or "peaceful" spoiling. Most importantly spoilers must be recognised and limited as much as possible.

Spoilers as a subject of scholarly research have been fairly unexplored. Stedman (1997, 2000) clarifies, spoilers are those actors or groups who believe that emerging peace threatens their power, their outlook and interests. Therefore they react by spoiling - using violence to undermine, hinder or delay attempts to achieve peace. Spoilers differ in goals and their commitment to achieving them. As such, Stedman identifies three types of spoilers: those whose goals are immutable, seeing the world in all-or-nothing terms; those who have specific goals that may or may not be negotiable; and those who are greedy and calculate cost and risk. A broader view of spoilers are any actors that are opposed to peaceful settlement for whatever reason - including those who are originally "in" the peace process but then withdraw or threaten to obstruct, or parties to the process who are not actually committed to a peaceful endgame (because they do not care either way, are too aggrieved to move forward or see new nonviolent opportunities for personal/group enrichment) - in effect "peaceful” spoiling (Mac Ginty 2006a; Newman and Richmond 2006). When extremism of violence is transferred into extremism of politics, even democratic politics, spoiling can continue by other means. However the label "spoiler" should not be ideologically directed at those who reject, for example, the formula state. Spoilers may even be external parties such as Diaspora communities, political allies or other entities. 


\section{i) Violent spoilers}

Violent spoilers are generally easiest to identify. DDR is already treated as an integral part of the peace process but often in a discreet fashion (Date-Bah 2003). It needs to be a central part of the ongoing paused-conflict governance strategy. Reintegration of those who carried arms (defence force, militias, rebel groups, child soldiers, freedom fighters, ordinary men and women) is hard. Previously armed groups often claim ongoing rights and hold knives at the throat of the transitioning society. War veterans in Zimbabwe, for example, have demanded a pension for life, destroying the national budget. They have taken land. The question is what to do with these trained people. Alternative strategies for violence or "muscle power" must be reinforced with such groups and at the same time their distinctiveness as a group must not be reinforced (pensions in Zimbabwe created a separate privileged group). This requires a holistic approach focusing on retraining and education initiatives, jobs and therapy - in an effort to keep them busy and allow them to reorient into "normal" society and become vested in the peace process (For the wider strategy, see: United Nations 2009). The challenges of DDR programmes are to be more embedded in the overall paused-conflict context and to present viable alternatives. Otherwise, such actors may backslide to violence.

Outright greed is often the primary motivation, with violence itself creating opportunities for profit. ${ }^{50}$ The continuation of violence, rather than military victory, is primary to certain groups. In Sierra Leone, the exploitation of diamonds by both sides to the 1990s conflict fuelled violence and rendered the peace agreements meaningless. While debate reigns as to whether the conflict was contested over the diamonds or merely with the diamonds (Newman 2006), the continued violence during and after the "peace process" demonstrates the link between the spoils of war and spoiling.

In the Democratic Republic of Congo (DRC), fighting over the valuable mineral-rich regions of eastern Congo characterised the conflict. Unlike Norway or Chile, most

\footnotetext{
${ }^{50}$ Regional linkages (trading networks, regional kin and ethnic groups, supporting neighbouring regimes) are associated stresses, not to mention developed world governments and companies who benefit from the natural resources (oil, natural gas, mineral coltan, drugs and diamonds). Uganda, Rwanda, Zimbabwe, Angola and Namibia were all implicated in predatory economic exploitation of the civil war in DRC and 85 companies were reported as in breach of OECD standards. See: United Nations Expert Panel, 'Illegal Exploitation of Natural Resources and Other Forms of Wealth of the Democratic Republic of the Congo ', (S/2002/1146; New York: United Nations Security Council, 2002).
} 
resource-rich countries (think Sudan, Afghanistan, Angola, Colombia, Liberia, Sierra Leone, Ache/Indonesia and Bougainville/PNG) are unstable, corrupt and have elites oppressive of minorities or other groups - the majority of the population does not benefit from the resource wealth (Ascher 1999; Ross 2001). Political scientists and economists refer to this as the "resource curse" or the "paradox of plenty". In addition, the character and duration of conflicts can be seriously influenced by resources as time goes by, even if resources were not the origin of the conflict, thus complicating efforts for other strategies away from violence.

Studies suggest that while some conflicts concern natural resources, they are seldom the sole or even main cause of conflict. Various governments (e.g. Norway, Canada and the $\mathrm{UK}$ ) and the UN have worked to develop sanctions, corporate responsibility and financially transparent extractive industries, as well as the World Bank and others (Ballentine and Nitzschke 2005). As Williams and Picarelli (2005) explain, resource control and interdiction regimes have inherent limitations as they rely exclusively on "supply-side" controls. Treating the symptoms, rather than the causes of conflict and the war economies fuelling them, is not helpful. Effective, transparent and equitable resource management must be an integral part of good governance programmes for paused-conflict governance, a subject that will be returned to in chapter 7 .

\section{ii) War by other means - "peaceful spoiling."}

Receptivity in this thesis is a true shift in mindset/paradigm. Zimbabwe currently illustrates the point. The opposition Movement for Democratic Change (MDC) operates in the political realm as opposed to Mugabe and ZANU-PF, who are still in war mindset (and who control the country's security force). As Luttwak (1999: 38) states: "Peace takes hold when war is truly over." It is possible that, even where groups are receptive to the alternative strategies, groups realise there are gains to be made in winning the war through indirect means. von Clausewitz (1993: 167) warned, in relation to Napoleon: "The aggressor is always peace-loving; he would prefer to take over our country unopposed." Conflict transformation, necessary for paused-conflict governance, instead requires neither a win nor a defeat but a willingness to put aside a group's particular view of history, justice and morality, to make sacrifices in the interest of peace and nonviolence and establish a common notion of justice. In the DRC the fundamental weakness of 
groupism, albeit powerful groups, was identified by the EU Special Representative - they could not make the peace process fail and assume the responsibility for that failure without committing political suicide because the population overwhelmingly supported the peace process. Therefore, the EU and other international actors employed a "name and shame strategy". The resulting public condemnation forced the groups to rethink their positions (Ajello 2008).

As such, receptivity should not be confused with a deadlock or a realisation that some impending catastrophe makes settlement ripe. Such timing considerations and perceptions originating in mediation/negotiation theory (Haass 1990; Stedman 1991; Zartman 2000, 2001) are just that, intervention strategies of international players. They are highly contested, not least because they only explain the opening of negotiations, not the process and are in effect tautological as where mediation is unsuccessful errors in timing can be blamed (Schrodt et al. 2003). Regardless of the attractiveness of this simple metaphor, when parties reach a mutually hurting stalemate a settlement may indeed be proposed and the timing may be ripe; however, without a mind shift from war to new rules for governance and inclusive politics, these are not likely to succeed. They may, in fact, arrest positive peace (Luttwak 1999). In $\mathrm{BiH}$, the criminal syndicates that did well out of the war still exist today and are embedded in and occupy vital positions in the state apparatus (Andreas 2004). Entrenched political corruption and rent seeking have undermined the rebuilding, eroded public trust in government (due to the relationships between criminals, politicians and the security sector) and impeded the creation of effective state institutions and the establishment of the rule of law. Cambodia in 1993 was ripe for settlement by one measure, but the reality proved otherwise. The international community allowed a powersharing arrangement without a genuine reconciliation between the parties and violence soon prevailed.

\section{iii) Mistaking the real spoiler in Cambodia}

Sometimes the overwhelming desire for peace can marginalise spoilers. There are obviously variables (position, number, location) which are pertinent. However, for paused-conflict governance, the ability to diagnose correctly the spoiler problem is a difficult task in the fog of peacemaking. Unlike many other post-Cold War conflicts, Cambodia's was not characterised by ethnic or tribal conflict, but a struggle for political 
power by four different groups (Chandler 1998). Under UN supervision, an international treaty was implemented by which the four contending Cambodian political parties - the Cambodian People's Party lead by Hun Sen; the National United Front for an Independent, Neutral, Peaceful and Cooperative Cambodia led by Prince Sihanouk; the Khmer People's National Liberation Front; and the Party of Democratic Kampuchea (the Khmer Rouge) - along with other countries, regional powers and Security Council members - agreed to the details of conditions for a "comprehensive political settlement of the Cambodia conflict" with the hope of assuring "human rights, and the non-return to the policies and practices of the past." ${ }^{, 51}$

Marginalisation was certainly the aim of the UN's subsequent Transitional Authority in Cambodia (UNTAC) in deciding to include the Khmer Rouge, who had been responsible for the deaths of over two million people from 1975-1979, in the Cambodian peace process. The Khmer Rouge responded initially, but when it became clear they would not hold power (Heder 1996), they made threats to disrupt elections and return to war unless certain demands were met. These included driving ethnically Vietnamese people from the country and the complete destruction of the CPP's administrative structures - a party which had been installed in government (1979-1989) by Vietnam. The core agreements of the peace process could not accommodate such demands. Since the Khmer Rouge could not be defeated militarily, it was hoped that peace would marginalise them (Solarz 1990). To counter their propaganda, the UN established a radio station in the lead up to the elections. While attacks on the UN forces were common, the Khmer Rouge did not launch any attacks against the elections but neither did they disarm. While the UN's approach to the Khmer Rouge may ultimately have been vindicated as their power declined (Stedman 2000), by treating them as having goals that were immutable, the UN missed a chance to induce more cooperative behaviour (Peou 2002). Throughout the transitional period, the Khmer Rouge had actually displayed a great deal of cooperative behaviour, and contrary to predictions, did not engage in a sustained campaign of terror or intimidation of voters (Heininger 1994). The Khmer Rouge leadership ultimately split and disintegrated. However, the attention directed to it allowed for a much 'quieter' spoiler to manipulate the peace process.

\footnotetext{
${ }^{51}$ Agreements on a Comprehensive Political Settlement of the Cambodia Conflict, UN Treaty No, 28613, Concluded at Paris on 23 October 1991, title and preamble.
} 
The CPP led by Hun Sen ${ }^{52}$ began violating human rights and intimidating both political opponents and civilians in the lead-up to the elections. Signs were evident early on, regardless of the warnings of UNTAC human rights officials, when CPP opposed the UN Security Council's call for proportional representation electoral system in favour of “winner-takes-all” single member constituencies, hoping this would deliver a monopoly on political power (Peou 2002: 512). As UNTAC military force commander, Lt General John Sanderson (1994: 18) observed: "the corruption of the peace process began in Phnom Penh", when Prince Sihanouk (later King) on his return to Cambodia attempted to form alliance with Hun Sen and, after a series of orchestrated demonstrations against representatives of the Khmer Rouge, ran them out of the city on their arrival for peace talks. When Prince Ranariddh's (Sihanouk's son) FUNCINPEC ultimately beat CPP despite its best efforts to demonise FUNCINPEC as a front for the Khmer Rouge, showing a never-ending search for "enemies" - CPP refused to accept the results and rioted. Fearing civil war, particularly since the CPP still controlled the armed forces, the UN agreed to a power-sharing arrangement which afforded CPP greater power and more ministerial postions than its electoral performance deserved. The overwhelming emphasis placed on the Cambodian election was to the detriment of "secondary" aims such as demobilisation and disarmament and human rights protection. Yasushi Akashi, the UN Secretary General's special representative, acknowledged that the deal was "unorthodox by universal democratic principles" but defended the "practical wisdom" of combining FUNCINPEC's political appeal with the governing experience and strength of CPP (Akashi 1993: 8). There is nothing wrong with innovative measures (with the "small" matter of who decides) but the UN failed to see that they were complicit in allowing the continuation of war by other means. CPP's increasing grip on power from 1993 caused experts to warn of "creeping coup" (Doyle 1995). Interestingly efforts by FUNCINPEC to integrate the remaining Khmer Rouge looked promising after Pol Pot's surrender in June 1997 and plans to recognise formally the constitution, disband its governing body and join government forces (Thayer 1997). However, Hun Sen and his party staged a coup, sending Prince Ranariddh into exile, assassinating FUNCINPEC officials and pro-democracy advocates. They manipulated the peace process to win, by other means, a war that they could not win through armed violence. 1995 is identified as

\footnotetext{
${ }^{52}$ While presented as a "moderate", Hun Sen had previously been a member of the Khmer Rouge. Before rebelling against Pol Pot in 1978 he allegedly had been one of Pot's most enthusiastic lieutenants in massacring Vietnamese.
} 
the year Cambodia's democratic forces were marginalised by traditional elites reinforcing factional hierarchy and the monarchy (Lizee 1996).

\section{BEGINNING THE SHIFT FROM WAR BY OTHER MEANS TO MAKING BELIEVERS IN THE PEACE PROCESS}

A policy of sufficient inclusion means that all groups in conflict must be included particularly those who have the power to bring the process down with violence (Hampson 1996).

While power sharing and electoral design strategies are intended to avoid polarisation and chauvinism, the enormous resources of the liberal peace (finances, political power, international legitimacy, etc.) and the monolithic nature of the enterprise to the determine of alternative forms of peacemaking, are an attractive prospect to many actors in the conflict. Elections do not make democracy. Any residual emphasis on elections followed by the enactment of constitutions marking the conclusive transformation of conflict sorely misunderstands conflict transitions and romanticises constitutions as well as elections.

First-past-the-post systems have long since fallen out of favour for states emerging from conflict. Kenya's 2007 deeply flawed elections and rioting, for example, were preceded by a host of difficulties regardless of the rose-tinted-glasses rosy view of relative stability since 1991. The Kikuyu and previously the Kalenjin tribes practiced winner-takes-all style politics, excluding and discriminating against other (mainly tribal) groups. A broad coalition of opposition parties from different ethnic groups came together in 2002 to overthrow the 24-year dictatorship of President Daniel arap Moi. The new government signed a memorandum of understanding to share power but in 2003 the Kikuyu revoked this agreement. A notable feature of Kenyan society was one of ethnic enclaves akin to apartheid. Kenyan political scientist Ngunyi asked his country the following question in 2003, a year after the Kikuyu leader President Kibaki came to power:

Consider a hypothetical situation here. What would happen if President Kibaki decided to run for re-election in 2007 and lost? Would he and his men have the grace to hand over power peacefully? From the way they have behaved in the last one year, I doubt it. And where would that leave the country? 
In Liberia, the implementation of the 1996 peace agreement brought an end to an eightyear long civil war. Elections in July 1997 were judged to be generally free and fair by international observers. Charles Taylor was victorious and became the president. The UN and other peace-builders declared the mission successful and largely withdrew. Shortly thereafter President Taylor began to reverse the fragile and preliminary movement towards democracy and reverted to a paranoid form of autocratic rule that all but put an end to organised opposition. There was nothing to stop him doing so because tiring with violence had not yet translated into institutional mechanisms to check power. After renewed civil war, he was finally ousted in 2003.

Generally systems which give voters more than one vote or allow candidates to be ordered preferentially are seen as providing the space for voters to cut across preconceived group boundaries - such as proportional representation (post-apartheid South Africa, $\mathrm{BiH}$ ), mixed member proportional (Lesotho) or preferential systems (Fiji, Papua New Guinea, Northern Ireland, Republika Srpska). The latter's alternative voting system was strongly advocated for in the 1990s to foster moderation between (ethnic) groups (Horowitz 1990, 1997; B. Reilly 2001). ${ }^{53}$ Pooling votes was purported to encourage conciliatory political parties and the formation of "resilient" intergroup coalitions. The failure of such strategies is evident. In Fiji extreme parties advocated voting preferences for parties further away on the political spectrum than parties which were closer (A. Ellis 2006). The result moderate parties finished last - and coups prevail. A similar pattern was evident in $\mathrm{BiH}$ 's Republika Srpska 2000 presidential elections.

However, the International Peace Academy case studies of constitutional design reveal no clear choice of electoral system and highlight the difficulty in trying to use elections to engineer particular outcomes, such as moderation or inter-group compromise (Kristi Samuels and Wyeth 2006). Employing mechanisms for free and fair elections, securing campaign and voting environments, educating voters and guaranteeing women's participation are in many ways straight forward, well outlined in literature and practice

\footnotetext{
${ }^{53}$ Particularly with ethnic groups in mind, it was thought that a preferential ballot would help flush out second and third preferences - obviously moderate parties - which would traverse the ethnic divided. More conciliatory stances on ethnically divisive issues are likely to be adopted, it is argued, as parties are incentivised to attract support from elsewhere.
} 
(see for example: International Institute for Democracy and Electoral Assistance 2002; The Organization for Security and Co-operation in Europe 2007; The United Nations 2005). Elections, which after all are a contest for power, legitimise winners and winners could be spoilers.

Peace can hide or even license the continuation of war by other means. For this very reason, a vocal minority argues against the erroneous belief in the democratising power of elections, proposing instead they should not necessarily take place immediately (Crocker and Hampson 1996; Paris 1997: 82-83; Walzer 1996). ${ }^{54}$ Holding flawed elections can "traumatise" a country when violence returns, reinforcing the notion that weapons are a better source of power, or that the people's choice is ultimately meaningless (Ottaway 1998: 150). Elections only make sense when a framework is in place which guarantees a modicum of the rule of law and security for citizens. The actual impact of elections remains an open debate. Taking too long to hold elections can breed mistrust, but interim governments may reinforce receptivity and provide the necessary space where the true tipping point from conflict to peace will be revealed.

The interest structures must change, and as the Northern Ireland case below illustrates, this can take a considerable amount of time.

\section{i) Northern Ireland - tiring, holding together, moving on, maybe?}

Sometimes poor decision-making or insufficient buy-in with regard to spoilers early on still has a way of working out if groups can be held together for long enough so that "normal" life can function. In Northern Ireland, exhaustion with violence occurred in the 1990s after over 3,500 deaths (1969-1998) from a conflict that had seemed as interminable as it was vicious (Fay et al. 1999). Tens of thousands of people were injured. Massive social and economic damage occurred. Britain publicly maintained a position

\footnotetext{
${ }^{54} \mathrm{In} \mathrm{BiH}$, the OSCE had to certify that the "social conditions" existed for elections to be effective (Dayton Accords, annex 3, art 1(2)), and this was done, reportedly under pressure from the US. See: Marynard Glitman, 'Us Policy in Bosnia: Rethinking a Flawed Approach', Survival, 38/4 (1997), 66 - 83 at 78. The result was that the power of extremist nationalists was consolidated and the country's division into separate ethnic enclaves, completed. The competition of democracy means that holding elections in divided societies may reinforce societal differences, allow for the manipulation of intergroup differences and instead of working for the broader public good, foster parochial exclusiveness. Adversarial politics sharpening conflict in divided societies rather than fostering tolerance, found in Bosnia, or Angola, but also Rwanda, Sudan (Muslim v Christian), Sri Lanka, Ethiopia.
} 
that it would not engage with the IRA. However with the passage of time at crucial moments there was, indeed, contact through informal channels (Mac Ginty et al. 2007). Talk proved the only way out in the three-cornered conflict between the large British Army and militarised police force, the IRA and other smaller pro-united Ireland militant group, and pro-UK militant groups.

The IRA and nationalists (mainly Catholics) wanted an end to British rule in Ireland - to unify with the rest of Ireland - and waged war to that effect. Local protestants were often targeted, giving the conflict its sectarian flavour. The majority protestant unionists (although a minority across the whole island of Ireland), wanted Northern Ireland to maintain its constitutional status as part of the UK (Elliott 2000; MacKay 2000). In a unionist Northern Ireland, nationalists felt discriminated against and in the late 1960s this often led to violent protests. Bombings and shootings resulted in causalities of politically uninvolved civilians, a disproportionate number of whom were young working class males (J. Reilly et al. 2004). Excessive reaction from the predominantly unionist police force provoked the emergence of militant groups on both sides - nationalists and unionists. British soldiers were dispatched to restore order. Conflict then ignited between the British army and the IRA, with unionist militants also attacking the IRA and its support community. The Northern Ireland Parliament was suspended in 1972 and governed directly from London.

With time, the strategy adopted by the British and the Irish (Republic) governments was to engineer a settlement that would attract support from both communities. The result the Anglo-Irish Agreement 1986. The inclusion of IRA militants contradicted the previous strategy of demonising violent actors, and this was difficult for the unionist majority to accept. Through the agreement, however, the British government recognised the constitutional aspirations of the nationalists as legitimate and also that the Irish Government could be a partner in the management of the conflict. It is this institutionalised relationship that has underpinned the peace process.

The militant organisations first had to show an interest in peace through word and deed. By 1994, the paused-conflict peace was unstable, dependent on speedy and successful talks to accommodate sharply varying preferences regarding the country's future. In February 1996, the IRA exploded a lorry bomb at London's Canary Wharf, frustrated at 
the slow pace of the British government in instigating multi-party negotiations. For the next 17 months, they carried out low level (compared to pre-1994) attacks in Northern Ireland. Care was taken not to harm civilians. A change of leadership in the UK (Tony Blair, elected in 1997) re-energised the talks which developed into multiparty negotiations between political parties leading to a comprehensive peace accord in April 1998 (the Good Friday or Belfast Agreement), the establishment of a power-sharing government, and relationships with the Republic of Ireland and the UK. A referendum quickly approved of the agreements -71.1 percent of voters were in favour (Coakly 2008: 103)

While the peace process suffered many shocks and setbacks such as broken ceasefires, the collapse of the power-sharing government, communal tension and violence from splinter groups, the process held. This is because of the intergovernmental relationship between successive British and Irish governments - who acted as guardians of the peace - and the lack of appetite among the militant groups and their support communities for a return to full-blown conflict. Even disaffected members of the IRA - the Real IRA and the Continuity IRA - were unable to attract much support once Sinn Féin was admitted to political negotiations. The Omagh bombing on 15 August 1998 killed 29 civilians and injured hundreds more - both Protestants and Catholics. Thought to be the work of the Real IRA, it provoked a wave of revulsion and mobilised the Nationalist community into a rejection of violence and spoilers (Dingley and Kirk-Smith 2000).

All groups in the peace process were included in the peace negotiations. Penalties for use of violence were clear with parties obliged to sign up to principles of non-violence or face exclusion (Mac Ginty 2006b). An Independent Monitoring Commission adjudicated on alleged cease-fire breaches and recommended penalties. "Acceptable" (low level) violence was tolerated in order to keep the groups together. Sinn Féin initially tried to fudge the issue of disarmament, fearing that it meant total surrender. The IRA eventually disposed of a first set of weapons in October 2001, and two further sets before decommissioning the remainder of its armoury in 2005. Unlike the Haitian examples given earlier, violence is no longer the means of getting things done. It is only a spoiler activity. Martin McGuinness, deputy first minister and leader of Sinn Féin (also second in command of the IRA in Derry, Dublin - by his own admission) (BBC 2010): 
Our experience demonstrates that the way to deal with any disputes or contention is through dialogue and agreement. There are numerous examples that show this to be the way forward. We are currently consulting on legislation that aims to provide a workable framework for dealing with contentious parades. Let's be clear there is no excuse for the violent scenes and attacks on police, property and the community that we have witnessed in recent days. We are resolute in our commitment to tackle sectarianism and will continue to work with all communities to promote good relations. This will require the community to stand united against all those forces seeking to bring conflict back on to our streets.

The Independent Monitoring Commission's latest report (2010) affirms that the IRA's leadership remains committed to the political path (para 4.4)

Political spoilers were another obstacle. The Democratic Unionist Party (DUP) thwarted the peace process by boycotting the negotiations leading up to the Belfast Agreement, campaigning vigorously against the agreement in the subsequent referendum and refusing to attend executive committee meetings (despite being part of the power sharing agreement) because of the presence of Sinn Féin. They blamed Sinn Féin and the IRA for the Omagh bombings and their election campaigns in the early 2000s were unashamedly anti-peace process (Democratic Unionist Party 2003: 6-7):

Sinn Féin/IRA's... so called ceasefire is a mere illusionary tactic, used to advance terrorist activity over the last five years and beyond, demonstrates that the IRA has not gone away but is continuing to re-arm and perpetrate terror, even while in government.

And having won power through the ballot box in 2003, the DUP were able to cease further implementation of the Belfast Agreement.

It is not surprising, therefore, that the peace process was judged a failure. It had led to "a continued and protracted stalemate beyond serious hopes of revival" (Peatling 2004: 5). Northern Ireland illustrates the weakness in placing too great an emphasis on "ripeness" and "mutually hurting stalemates." While relatively peaceful in terms of physical violence, and a positive example in dealing with certain types of spoilers, the peace process initially seemed to fail to transform the attitudes that underpinned the conflict. Instead, the 1998 peace agreement bolstered continued allegiance to traditional single identities by legitimising, via the power-sharing arrangements, Catholic nationalism and Protestant unionism (McAuley and Tonge 2007). Evidence of this can be seen in the 
increasingly polarised voting patterns in post-agreement elections where the hard-line DUP and Sinn Féin, outpolled the more moderate Ulster Unionist and Social Democrat \& Labour Party (despite the leaders of both winning the Nobel Peace Prize). The Assembly has been suspended on several occasions, the longest suspension running from 14 October 2002 until 7 May 2007. Powers then reverted to the Northern Ireland Office.

Perhaps there are indeed circumstances where elites leading opposing parties representing the most militant strands on each side can cooperate and present alternative strategies to violence or war by other means. Early optimism over the peace process was unfair for there was never going to be a quick fix in light of two inclusionary processes - both sides being fixated on the Westphalian sovereign state and two groups attempting to impose their preferred form of integration on those that did not want it. Today, Northern Ireland has agreed to accommodate two distinct national communities that span two states. Peatling's conclusion now seems less clear-cut. In 2006, only 24 percent of those surveyed felt confident that Ian Paisley and McGuiness would be able to work together as first minister and deputy first minister. By mid-2007, however, with the two men heading the new government that figure shot up to 67 percent (Coakly 2008: 106). The right institutional incentives have propelled these parties towards more moderate platforms. Following talks that resulted in the acceptance of the St Andrews Agreement in November 2006, an election to the Assembly was held on 7 March 2007, and full power was restored to the devolved institutions the next day. Some nine years after the peace agreement was signed, the formerly extremist parties agreed to become consuls in government together, dividing portfolios using the d'Hondt method explained in the previous chapter. There is evidence of facilitated moderation rather than polarisation (Garry 2009). Although disagreement between the parties over the devolution of responsibility for policy and justice led to a five-month government hiatus in 2008, an agreement was reached towards the end of the year. And further tension, such as the dissident republic violence of May 2009 where two soldiers and a policeman were murdered, was strongly condemned by Sinn Féin. Powers in relation to policing and justice were transferred to the Assembly on 12 April 2010.

Northern Ireland may be moving out of its "no war no peace" phase (between points 3 and 4 on Figure 2 above). It is not however a model for other conflicts but a product of its own unique context. With a fall-back position of being ruled from London, it also may 
be the only conflict where rubbish was collected weekly, so to speak - the media was free, civil society was growing, and extensive human rights and equality legislation existed. It also lacked the problems associated with conflict states in the developing world such as "hostile neighbours, lootable natural resources and the multiplicity of armed groups that contribute to the vastly more complex peace implementation environments in other locations" (Stedman 2000). Here Stedmen is referring to the lack of complex social emergencies such as public health catastrophes or large-scale population displacements which characterise many civil wars, Northern Ireland has achieved - with much stumbling along the way - a complex power sharing arrangement. One that has been designed to prevent majoritarian rule and polarising blocks of power, thus perhaps affording it an opportunity to pacify slowly.

Bougainville, on the other hand, is one of the best examples of renouncing violence and accepting peaceful strategies to begin the learning that comes next.

\section{BOUGAINVILLE - FROM CIVIL WAR TO "PEACE BY PEACEFUL MEANS." 55}

Bougainville's decade-long civil war (1988-1998) was the most brutal in the Pacific postWWII. The fear of "others", as well as longstanding rivalries and tensions, saw individuals and groups become increasingly engaged in violent conflict. People were injured and killed, ${ }^{56}$ along with damage and destruction of public and private property which nearly destroyed the social and economic infrastructure (Joint Standing Committee on Foreign Affairs 1999b: 13). Conflict arose partly over issues concerning the enormous Panguna copper and gold mine owned by the government of Papua New Guinea (PNG) and Conzinc Rio-Tinto of Australia Limited (later, after a merger, Rio Tinto Limited with Anglo-Australian owners $)^{57}$ and also growing demands for independence from PNG. Independence demands had intensified from the 1960s onwards (Alley 2003: 226-31), ${ }^{58}$

\footnotetext{
${ }^{55}$ Concept introduced by John Hayes, former New Zealand High Commissioner to Papua New Guinea, in Port Moresby (personal conversation on file with Andrew Ladley) and adopted by the Bougainvilleans.

${ }^{56}$ Directly or indirectly $10,000-20,000$ people died during the conflict. Some as a result of Bougainville being cut off for a period by the PNG government which resulted in social services not being delivered.

${ }^{57}$ By the late 1980s, taxes on the Panguna mine accounted for one third of the national budget.

${ }^{58}$ Bougainville is an island $1000 \mathrm{~km}$ northeast of Port Moresby, PNG. It has more in common (culture, ethnicity, tradition and geography) with Solomon Islands. At the end of the nineteenth century, the islands of Bougainville and Buka (today Bougainville's two main islands), as the north Solomon islands, were portioned off from Solomon Islands and made part of Germany's existing New Guinea colony in a deal
} 
and the ethno-nationalist character of the conflict solidified as the PNG Defence Force (PNGDF) reacted in "poorly judged" and "ill-disciplined" ways (Regan 1998b: 277). Gregory Singkai, the Catholic Archbishop of Bougainville at the time, condemned the violence (Carl and Sr. Lorraine Garsu CSN 2002: 9):

They are really unruly and undisciplined. They are bashing people without questioning them and putting them in jail. They are destroying people's property, shooting cars, destroying their food gardens. People are really scared of them. Many innocent people, old people, women and children are being slaughtered.

In 1990, the violence worsened significantly. On February 14 the PNGDF appeared to have been responsible for the death of six people suspected of being 'militants' in what became known as the St Valentine's day massacre. Five bodies were dropped at sea from Iroquois helicopters supplied by Australia's Government purportedly on the condition that they would not be used in combat (Dorney 1998: 40-41).

The resulting legacy of fear and suspicion of the PNGDF consolidated Bougainvilleans (initially) behind Frances Ona and his Bougainville Revolutionary Army (BRA). A Bougainville Interim Government (BIG) was also appointed. However, neither of these bodies had control over the BRA fighters who were mainly frustrated young men with few economic opportunities (some little more than criminals). These men focused on perceived enemies within Bougainville - those suspected of cooperating with the PNG government or those seen as wealthy (i.e. the village of Ieta was burnt by men from the poorer mountain areas), not just the common enemy (PNGDF). With the common enemy officially off the island by mid-1990, many group-based disputes erupted resulting in harassment, imprisonment, torture and murder. Joseph Kabui, Vice President and de facto leader of the BIG (Ona being the President) admits they realised early on they brought about anarchy. And this consequentially caused division and infighting amongst people who had once been united: clan against clan, generation against generation, class against class (Kabui 2001: 33). Traditional and new rivalries (over power) along with the

with Great Britain. PNG gained independence in 1975. Bougainville self-determination was denied despite potentially being a viable state with rich natural resources. Bougainville eventually agreed to remain part of PNG with a degree of autonomy through a provincial system of government. The borders created by the colonial powers split family and cultural ties established over generations. For a history of the partition and subsequent administrative role of Australia, see: Brenda Tohiana, 'Weaving Bougainville Together. ReBuilding Broken Communities: Restoring a Shattered Society', in Arlene Griffen (ed.), Lalanga Pasifika: Weaving the Pacific - Stories of Empowerment from the South Pacific (Suva: University of the South Pacific, 2006), 164-238. 
associated attacks on civilians and human rights abuses, ultimately prompted armed opposition - Bougainville Resistance Forces (BRF) (Boege 2006b: 6).

The conflict may have been triangular -between Bougainvilleans and the PNG government forces and between the BRA and the resistance. However changing allegiances, little command and control across those forces and even fighting within the groups made Bougainville an increasingly violent place creating a lawless vacuum of civil strife (Regan 1998a: 279). Boege (2006a: 5) observes how the violent conflict produced "payback" where losses and fighting became a cause for even more fighting, prompting a vicious circle, indeed a culture, of violence. By 1997 Regan observed social disintegration, direct casualties, much suffering and indirect deaths from the breakdown of services and blockage of medicine and supplies, severely damaged infrastructure, and around 60,000 people (a third of the population) were in care centres where they then suffered at the hands of the PNGDF (Regan 1998b: 279; 2001). Directly or indirectly the figure of several thousand (Regan 2010: 26) to between 10,000 -15,000 (Joint Standing Committee on Foreign Affairs 1999a, 2.1) in a population of approximately 160,000 civilians died either by direct fighting, disease, or deprivation of basic needs. In addition the economy had stagnated, educational opportunities for a whole generation were missed, and most of the impressive capacity (strong community support and revenue base) of Bougainville's provincial administration was destroyed.

Between 1990 and 1997 tentative moves toward peace were stymied by distrust, reneging on promises and further violence (including the Endeavour Accords 1990, Honiara Declaration 1991, Arawa Peace Conference 1994, Mirigini Charter 1994. See: Braithwaite et al. 2010: 26, 31-32, 35-36). The road to a paused conflict situation occurred after the Sandline Affair and the development of moderate leadership looking to bridge the deep divisions within Bougainville as well as a mood change within the general population towards peace. The peace movement evolved during the mid-1990s led by women's groups, churches, NGOs, chiefs of Bougainville, who initiated indigenous conflict resolution practices assisted by moderate leaders on all side (Braithwaite et al. 2010; Saovana-Spriggs 2010: 40). Former Judge Theodore Miriung became a rallying point for those prepare to negotiate with the PNG government. While murdered in 1996 
by PNGDF soldier (Report of Coroner T. Suntheralingam 1996) ${ }^{59}$ - the transformative civil-society push for peace he championed had planted seeds of doubt in the mind of inner-circle BRA leaders (Kauona 2001). A further boost to the peace framework occurred in 1997 when the PNGDF revolted over the leaked government plan to employ private mercenaries from Sandline International to defeat the BRA and take control of the mine (see Andrew 1997; Joint Standing Committee on Foreign Affairs 1999b: 29-39; O'Callaghan 1997). The resulting constitutional crisis led to the resignation of Chan provoked international condemnation and ended any option of a military solution.

Bougainvilleans realised that they needed first to reconcile with each other before settling differences with PNG, and also that this should not be rushed. For it was not the mining and commercial representation issues that assumed direct roles in the peace settlement and subsequent reconciliation and peace-building, but other often longstanding issues, some ephemeral, which characterised the conflict. Women's groups, churches and chiefs had begun to pressure the conflicting groups to negotiate for peace (Tapi 2002). Women acted as go-betweens with the warring factions to maintain constructive dialogue and mothers tried to bring their sons home by venturing into the bushes, even negotiating directly with the local BRA in the south and southwest regions (Carl and Sr. Lorraine Garsu CSN 2002: 28-31). Few schools were operating, the blockage was hurting with medical supplied difficult to get: "They were in desparate need of freedom from fear and freedom of the mind - there was a whole generation that didn't know what that meant"(Kauona 2001: 85).

The role of women as has been identified as "pivotal" - as a predominantly matrilineal society and one in which Catholicism and the worship of Mary accentuate the women's roll as custodians of the land afforded them status and influence, particularly with their direct family members. In times of crisis matrilineal links that were the relationships that had been relied upon for garnering support and allies (Oliver 1973: 68-74; 1991: 6) and on mass, they had had enough of the violence (Josephine Sirivi and Havini 2004). The significance of their influence and opinions on fighters across sides has been documented

\footnotetext{
${ }^{59}$ There is some suggestion that it was actually the resistance. See: Guy Wilson-Roberts, 'The Boungainville Conflict, an Historical Overview', in Rebecca Adams (ed.), Peace on Bougainville (Wellington: Victoria University Press, 2001) at 29.
} 
in interviews conducted by Reddy (2006: 226) and also in the experience and determination of Bougainvillean in to accentuate the readiness for peace and learning collected by Sirivi and Havini’s (Josephine Sirivi and Havini 2004).

The savagery and brutality of the conflict shocked people in a society were violence and conflict was limited including against women (Nash 1992; Oliver 1973: 201). Previously existing society practice identified the rhythms of life having to be restored after the tribal conflict which was traditionally short-lived. But this conflict as well as causing casualties amongst fighters has seen attacks on civilians, assassination and murder, destruction of villages and rape and torture as a form of punishment and domination by one faction over another. The availability of weapons has been identified as making this easier (Reddy 2006: 220).

Brigadier Roger Mortlock, the New Zealand head of the Truce Monitoring Group (TMG), reported back the observation of BIG deputy leader, Joseph: "There is a desire for peace sweeping this land, and if we, the leaders, want to keep our jobs, we had better sit up and take notice of it" Kabui (Mortlock 2001: 71). This desire was so strong that Bougainvilleans refused to let Ona or his loyal Me'ekamui faction ${ }^{60}$ derail the process, despite orders to kill peace process leaders and intimidation (Kauona 2001: 86, 92). The masses who wanted peace ( $90 \%$ in Kabui's view), helped appease fears of a "loose cannon" taking a pot shot at a member of the TMG and left incidences, such as opening fire on the helicopter carrying New Zealand diplomat John Hayes (an incident that New Zealand chose not to publicise to the world), without any reprisal (Kabui 2001: 38; Mortlock 2001: 73).

\footnotetext{
${ }^{60}$ The Me'ekamui Defence Force (MDF) was formed as a separate paramilitary force in 1998 after differences with the BRA over tactics and continued engagement with the peace process. Ona was concerned that this was diluting the BRA's independence objectives, declaring Bougainville the Republic of Me'ekamui (a word Nasisi word meaning 'holy land') and himself President. The MDF did not all remain outside of the process, in fact, Damien Dameng's participation brought in a number of other members and a partial reintegration of members into the peace process occurred. Ona however, remained outside, until his death in 2005. The MDF under the leadership of Chris Uma, continued to be separate, not recognising the Autonomous Bougainville Government, although in April 2010 they gave their support to President James Tanis who said he could work with the splinter group if re-elected, after signing an agreement for continuous dialogue and an alliance to work together for Bougainville's future. See: Andy Carl and Sr. Lorraine Garsu Csn (eds.), Weaving Consensus: The Papua New Guinea - Bougainville Peace Process, ed. Celia Mckeon (Accord, 12; London: Conciliation Resources, 2002) at 89. an, Pacific Islands Broadcasting Corporation, 'Rebel Group Backs Bougainville President', Islands Business Monday 17 May 2010.
} 
Peace talks held in New Zealand first addressed intra-Bougainville conflicts including almost 100 leaders (women's groups as well as the Kauona and Kabui, the new premier of the Bougainville Transitional Government Gerard Sinato and Bougaivillean MPs elected to the new PNG Parliament). Lasting over ten days these involved a traditional vomiting sessions where emotions are vented without restrained. This can be spoken, shouted or cried out - in other words, a kind of venting of psychological poisons. In a 2004 interview Reddy captures the spirit of Burnham I:

\footnotetext{
There were no specific procedures - we went into the room with NZDF in between our factions - we were ready to throw punches. The vomiting session united us and from then on we stood back as one. The BRA and the BIG were housed together, but separate from the Resistance. There was real enmity. It was really very difficult. Someone would shout to another person, 'You shot my brother, you murdered my brother'. And they would jump across to do violence but the NZ military were in between. This went on until nothing was left inside. The women played a very important role, they would say 'Look, I am here, there is my son over there, and over there is my other son. And all of you, you are all our sons.' During this time, there was no agenda and it was so important to vomit it all out. (Reddy 2006:228)
}

As the talks developed and moved on to include the PNG government, "peace by peaceful means" became the accepted wisdom of the Bougainville peace process. Mortlock introduced the metaphor of a river - flowing from its source to a final destination - not in linear fashion, but meandering around rocks, sometimes running freely and at other times barely moving, but always continuing to flow. The receptive groups in Bougainville understood this image, and it helped to build trust and confidence in the process. Gerard Sinato, the Premier of the BTG in 1997 took ownership and used the phrase constantly (Kabui 2001: 40). This language became part of the Lincoln Agreement on Peace, Security and Development on Bougainville signed on 23 January 1998 (hereafter the Lincoln Agreement):

Peaceful Means

The parties will cooperate to achieve and maintain peace by peaceful means. They also pledge to renounce the use of armed forces and violence and agree to resolve any differences, by consultation, both now and in the future. They confirm also their respect for human rights and the rule of law. 
Peace by peaceful means held the process together for the Bougainville Peace Agreement signed on 30 August 2001. The opening paragraph of which reads:

This agreement is a joint creation by the Government of the Independent State of Papua New Guinea and Leaders representing the people of Bougainville ("the Parties") to resolve the Bougainville conflict and to secure a lasting peace by peaceful means...

The agreement gave autonomy to the region and allowed for the containerising of all weapons. Kabui observes: "The weapons were their source of confidence, comfort and protection for well over a decade of conflict. To put away their most trusted 'friend' is indeed an act that was unthinkable only a few years ago." (Carl and Sr. Lorraine Garsu CSN 2002: 64). Awareness of the need to settle helped solidify a consensus on the principle that the territory could not function in future - whatever its status - outside an institutionalised dialogue between Bougainville and PNG authorities. Violence, would not help either side in this regard.

\section{CONCLUSION}

Receptivity is the move away from violence to the acceptance of other strategies for dealing with conflict. Where positive, disarmament, reconciliation attempts and complete buy-in to the peace process are evident. The decline of violence worldwide has had profound results. However least this become a license for complacency, it is recognised that peace exists because people were revolted by the experience of violence in their time and created rules to contain it. The articulation of a better way needs remembering, as the recent furore over the violent methods used against those suspected of terrorism illustrates. In this regard, Bougainville represents the wisdom in reinforcing receptivity, specifically through the mantra of "peace by peaceful means", and recognising the value in reconciling groups before moving to establish concrete governance strategies which could exacerbate existing rivalries. Receptivity, where positive (as opposed to strategies that simply continue war by other means), creates a platform to negotiate rules of governance based on agreed learning - the theory of the next chapter. 
The challenge may still be to devise governance institutions and electoral rules which encourage serious candidates to be moderate and seek significant cross-factional support - but there is no magic formula in this regard. Rather than focusing on free and fair elections, fostering mechanisms that will change attitudes and expectations in the direction of building confidence in peace are required. International actors can assist in directly funding citizen's organisations, and associations build cooperation between groups in war-shattered societies, in order to prevent exclusionist groups from monopolising political life, and to build "social capital" (Putnam 1995). Women, as Bougainville shows, are not only often the majority in populations devastated by death and displacement, but are a tremendous resource for conflict transformation and should be treated as equal "owners" in peace efforts.

Where these is no sufficient consensus on positive strategies for peace, singular identity groups flourish, war continues, and enemies must still be found and dealt with. Often the allure of the rewards of the state apparatus masks war weariness and quickly is revealed as the continuation of war by other means. Strategies to deal with spoilers in this regard vary from the well-established practices of DDR to the more difficult ways in which to foster moderation in politics. Moderation may only occur if groups can be held together for long enough to see the merits in tempering seemingly entrenched positions, or be forced to do so by the wider population.

In the next chapter, we turn to learned constitutionalism which continues the themes of experience and learning and represents a more focused look at the past and the future of the paused-conflict society in question. In creating new systems, elites all over the world (in varying degrees of the concert with their peoples), reached for new rules. Overwhelmingly, those rules were, at least in form, democratic constitutions. Democracy may be the best endgame currently foreseeable but, rather than reverse-engineering, dealing with the past (reconciliation) and imagining a future (governance, accommodating multiple and overlapping group identities), requires local ownership and the embodiment of that particular society's own struggles, battles and ensuing lessons. The point at which this learning materialises in the acceptance of new rules for governance is when Leviathan may be pacified. 


\section{6: Learned Constitutionalism - learning lessons for governance}

\section{LEARNING LESSONS}

In stable democracies after years of war and conflict, lessons were eventually learned to articulate the suffering of the past and ways to avoid the capacity of humankind to do violence - the repetition of conquest, of civil war, of slavery, of overwhelming civilian casualties, and of torture and mutilation as routine punishment. ${ }^{61}$ In these societies, the rejection of violence turned into accompanying political support for constitutionalism that transformed them into inclusive, peaceful states.

Where change happen swiftly (and sometimes peacefully) this is a sign that incremental peace-building has reached what others have called a critical mass (Rogers 1995), or a tipping point (Gladwell 2000) or even, a stage of "ripeness" (Zartman 1985). However, giant steps in learning on the surface are more likely the result of the slow and less visible experiences and decision-making processes. Such as those shaped by the past and an imagined future (perhaps through peace conferences) that culinate in the articulation of new rules that are owned by the people. There are many examples in history where ideas seemed to take suddenly hold - such as the major social movements in the $19^{\text {th }}$ and $20^{\text {th }}$ centuries concerning national struggles for independence from colonial rule (Norway, India for example) and working-class movements for union collective bargaining rights. After the Great Depression, the vulnerability of democracy in Europe was faced with fierce ideological challenges of fascism and communism. In the UK, the small number of "black shirts" (the British Union of Fascists) was crushed by middle-class values, most notably when violence was added to the mix. In other places, different results emerged which spread the learning over generations as trial-and-error processes of regime

${ }^{61}$ For a general overview of such lessons, see books on human rights' development such as Helen Stacy, Human Rights for the 21st Century (Standford: Standford University Press, 2009). 
alteration occurred (R. Rose and Mishler 1996). This is not to say that democracy is the end of history, but rather that the liberal state's Leviathan has made peace with itself under current threats and conditions.

The precise moment that receptivity tips into new rules of governance is challenging to pinpoint. After the fact, it may be easy to identify factors leading up to the change but at the time, as Gladwell (2000: 12) explains, the tipping point is: "the moment of critical mass, the threshold, the boiling point". Similar to the processes that bring about collective madness, the level is when momentum for change becomes unstoppable. A critical mass is a crucial factor; it is not necessarily enough that elites want to assist change as they may not be able to control their respective groups or that the mass of individuals desperately yearn for something more but are held in check by an authoritarian regime. Contest will always be there, but the mass of individuals, leaders, ex-combatants, victims, all of whom firstly need to reorient from violence (exhaustion), must take the time to reconcile, to build the constitution and rules of the game - becoming believers in the process, discussing the issues, strengthening the rules, defending them, remembering. It is only then that groups may be willing to come together for governance through the perception of shared interests, of commonality, or security, contributing towards the generation of a web - albeit a fragile one - of alternative identities that can reduce the salience of the identity conflicts and division discussed in Chapter 4, and, instead, create larger groups constituted around governance.

Traditionally, this process is thought to be embodied in the waves of constitution-making which have followed the creation of states. Therefore the omnipresent status of constitutionalism in post-Cold War, post-conflict settings, should signal that constitutionmaking is a widely agreed upon and understood the phenomenon. Yet few within the dominant discourse of liberal peace-building see constitutions as truly embodying particular polities' own struggles and battles, including attempting to project forward with contextually appropriate guiding rules based on learning. Instead scholars of constitutionalism like Howard (1991), view constitutionalism in line with a Diceyan interpretation of the British constitution (consent of the governed, limited government, the open society, sanctity of the individual, the rule of law, enforcement of the constitution, and adaptability), which are acutely foreign to the kind of learning required in post-conflict contexts. 
Transplanting of imported and hence unfamiliar constitutional forms has been criticised but repeatedly resuscitated. Not surprisingly, paused-conflict states find it impossible to govern themselves with model solutions which fail to consider the richness of the national, cultural, political, and temporal context. It is argued here that romanticising constitutions based on a rose-tinted glasses' view of modern constitutional triumphs such as the USA's independence constitution, has implications for learning and reflects a flimsy appreciation of groupism and exhaustion. This is vividly apparent in the American constructed constitution of $\mathrm{BiH}$ that formed part of the Dayton Accords. The absence of learning - including dealing truthfully with the pain of the conflict period in order to establish a "usable past" - translated into constitutions means that it impossible for countries to practise constitutionalism and imagine a shared future. It is only then that rules and creeds can emerge, be codified in constitutions and in conventions and in cultural rules of government that continue to develop, be institutionalised, articulated in court decisions, recorded in historical narrative, heard in leaders' oratory and perhaps assisted by international actors.

\section{CONSTITUTIONS AND CONSTITUTIONALISM}

In Modern Constitutions, Wheare (1966: 1) defines constitutions as: "the rules which establish and regulate or govern the government." Constitutions are often described as "power maps", deriving their mandate from the governed and regulating the allocation of powers, functions and duties among various agencies and officers of government, as well as defining the relationship with the "governed". In other words, constitutions form the main source and basis for governmental rulemaking and are primarily designed to check against capricious or arbitrary rulemaking. This power map may be found not in a single document but also in key rules (written or otherwise) such as human rights' charters (i.e. EU Declaration on Human Rights), parliamentary codes of conduct, the role of the military, accepted societal practices - even peace treaties. A "constitution" is actually made up of structures, processes, principles, rules, conventions, and even culture that comprise the ways in which government power is exercised (Palmer 2006). 
In Western democracies, constitutions are somewhere in between the two models outlined in the literature (Habermas 1998a; H. Lerner 2010; Muller 2007) in the way they conceive of identity - the nation state constitution (strong national identity, perhaps homogeneous but could be imagined) ${ }^{62}$ and the liberal procedural constitution creates "the people" (the private sphere of religious and ethnic identity separated from public sphere of civic or “thin" identity). ${ }^{63}$ A combination of thick identity elements - religious, linguistic, national - meshes with liberal principles and human rights, and, most importantly, a wide societal consensus exists regarding the foundational elements of the constitution.

The distinction between constitutions and constitutionalism is more than mere semantics (Curry et al. 1999: 4). Constitutionalism is the act of being controlled by the rules, not limited only by the desires and capacity of those who exercise power (Wheare 1966: 137). But it is more than that; constitutionalism is closely linked to the rule of law. Constitutionalism requires political justice (Rawls 1996: 4-35). For Rawls, political justice has three features: 1) a specification of certain basic rights, liberties and opportunities; 2) an assignment of special priority to those rights, liberties and opportunities, especially with respect to claims of the general good; and 3) measures assuring to all citizens adequate all-purpose means to make effective use of their liberties and opportunities. Many constitutions seek to build what we might call a 'charter' of values to set a course for the relationship between the citizens/peoples and the reimagined state. Unsurprisingly, inclusiveness and non-discrimination are generally at the heart of such charters. In new states founded upon complex identities, and often competitive religious denominations, suggestions of the perpetual dominance of one group would smack of racism, apartheid and religious bigotry. These claims of fundamental values were often contained in preambles to a constitution, or in the early sections. They are also social constructions of history and identity - the state claiming new governance and values for a wholly new group (Liu and Hilton 2005).

\footnotetext{
${ }^{62}$ Examples of this include constitutions which establish a national language (France), an official state religion (Iceland, Norway) or privilege "ethnic" citizens (ie. Germany's immigration laws up until 1999).

${ }^{63}$ The US constitution is a good example of the people coming together through the constitution with shared democratic procedures being the binding force of the new polity. See: Bruce Ackerman, We the People: Foundations (Cambridge Harvard University Press, 1991).
} 
In that regard, this thesis argues for an even more expansive definition of constitutionalism - learned constitutionalism. ${ }^{64}$ The Constitution of the USA starts with the phrase, "We, the people ...". This makes sense on the basis of the assumption of such a pre-contractual "we". History is full of examples illustrating the rules and creeds that have emerged out of learned constitutionalism. The federal conventions of the $1890 \mathrm{~s}$ in Australia, ${ }^{65}$ the Magna Carta $1215,{ }^{66}$ or the UN Charter 1945 - which in many respects is the mother of all constitutions. The process of learned constitutionalism, therefore, encompasses the processes and mechanisms which led up to the decision to create a new "constitution". 67

Liberal learned constitutionalism has emerged from the particular historical context of the societies in questions with many familiar elements such as the separation of powers, the review of the constitutionality of laws and the control of the amendment. However the tendency to propagate and adopt model forms of institutions and rights that experts are convinced will address particular problems of governance or social conflict in pausedconflict states has been criticised but repeatedly resuscitated. As Learned Hand said (1959: 190): ${ }^{68}$

Liberty lies in the hearts of men and women; when it dies there, no constitution, no law, no court can save it; no constitution, no law, no court can even do much to help it.

\footnotetext{
${ }^{64}$ The literature uses the terms "constitution-making" and "constitution-building" interchangeably to refer to the immediate processes of writing, enacting and implementing a constitutional document, with or without international involvement. Arguably "making" is narrower - encompassing the immediate task of drafting and implementing the said constitution. "Building" implies an ongoing process but neither of these terms is used in any defined way here because of the haphazard and uneven use of these terms in peacebuilding literature.

65 Records of the Australasian Federal Conventions of the 1890s, available at http://www.aph.gov.au/Senate/pubs/records.htm (last accessed 19 August 2010)

${ }^{66}$ Much of the Magna Carta has disappeared into history; however the protection of the rights of citizens against the limited power of government - which at the time was the agreed outcome of the civil war between King John and a number of his barons - is today at the heart of the rule of law and of constitutionalism itself.

${ }^{67}$ Ghai and Galli recognise this distinction generally in relation to the future evolutionary process of nurturing the text. 'Constitution-Building Processes and Democratization: Lessons Learned', in Reginald Austin, Najib Azca, and Feargal Cochrane (eds.), Democracy, Conflict and Human Security: Further Reading (2; Stockholm: International IDEA, 2007), 232-49.

${ }^{68}$ Hand originally made this observation in a speech, The Spirit of Liberty, at an 'I Am an American Day' ceremony in Central Park, New York City, on May 21, 1944. This precise citation is often used in the USA to warn against reliance on judicial review as a mechanism for avoiding the implementation of unconstitutional legislation. Hand was however focused on constitutionalism itself.
} 
In post-conflict contexts, it is society's exhaustion with violence and accompanying support (or critical mass) for new rules by which the Leviathan is pacified. Learned constitutionalism is the idea that there must be clearly articulated lessons rooted in the historical experience, otherwise there is no "usable past" - the search for historical experiences which might be drawn on in the effort to legitimise and then stabilise governance after conflict, before the drafting of actual written constitutions and the building or rebuilding of institutions of governance. Rules and creeds can emerge, be codified in constitutions and in conventions and in cultural rules of government that continue to develop. Learned constitutionalism, therefore, refers to the wider picture taking stock of the events leading up to the decision to create a new constitution or amend or reinstate and/or the other agreements and processes that might have constitutional effect, as well as the issues relating to making the constitution "work" with enough flexibility to adapt and be strengthened as the state solidifies over long periods. It can be enabled and facilitated by certain conditions, including appropriate international interventions. More obvious pointers of common identity come later: symbols, cultural traditions, customs.

\section{i) Waves of constitution making}

The history of constitution-making as the foundation of the state can, like democracies, also be seen in waves:

- the late 18th century cases of Poland(1791), France and the United States (1787), preceded in 1701 by the UK's Act of Settlement ${ }^{69}$ which along with the Bill of Rights 1689, are the cornerstone of the British (unwritten) constitution;

- in the wake of the 1848 revolutions in Europe (see Robertson 1967);

- after WWI including the Weimar Constitution of the newly defeated German state and the creation and recreation of Poland and Czechoslovakia; and

- after WWII with the adoption of new constitutions by the defeated powers under the "more or less strict tutelage of the Allied Powers" (Elster 1995: 369).

\footnotetext{
${ }^{69}$ An Act for the further Limitation of the Crown and better securing the Rights and Liberties of the Subject (12 \& 13 Wm 3 c. 2$)$.
} 
The post-WWII period saw:

- the beginning of the breakup of British and French colonial empires, which gathered speed in the 1960s and birthed a constitution production factory for new states modelled closely on those of their former colonial masters ${ }^{70}$

- the process of democratisation (or "deepening democracy") saw new constitutions in Latin American and parts of Asia;

- the fall of dictatorships in Southern Europe during the mid-1970s resulted in the adoption of new constitutions in Portugal, Greece and Spain; and

- towards the end of the $20^{\text {th }}$ century, the collapse of communism in 1989 precipitated regime change in Eastern Europe and the Baltics, necessitating further constitution-making.

In the period following the fall of the Berlin Wall, constitution-making has had to address fundamental institutional crises in addition to regime change. States "failed", sometimes in the context of the collapse of communism and sometimes, as in parts of Africa (Nigeria, Zambia, Tanzania, etc.), as part of the wave of democratisation that followed the fall. However constitutional theory, until very recently, tended to focus on constitutions in stable political contexts, rather than their role during periods of political change. This is partly due to the post-WWII dominance of the realist approach in political theory, which saw constitutions as mere reflections of the balance of power at the time of drafting and did not consider them to have any particular role as agents of change or transformation. Of late there has been limited acknowledgment of 'transitional constitutionalism' - the constitutional development that occurs immediately after a period of substantial political change. As Teitel (1997: 2076) points out, constitutionalism is: "inextricably enmeshed in transformative politics", can codify the prevailing consensus, and also transform it. Therefore, while a group of lawyers could produce an excellent constitution, constitutionalism has moved on from the notion that an expertly drafted constitution is all that is necessary.

Constitutions are not a panacea for the problems of paused-conflict governance. However in practice constitutions, like elections, are seen as the first key challenge for post-conflict peace-building to provide for political and governance transition. They determine the

\footnotetext{
${ }^{70}$ For example the constitution of the Ivory Coast was modelled on that of the Fifth French Republic, whereas those of Ghana and Nigeria followed the British Westminster model.
} 
overall system in which people live together and are therefore also the starting point either for future turmoil or for societal stability and integration. While the liberal peace-building sees constitutions as recipes for conflict resolution, in this thesis they are mere ingredients (and representative of others) in the process of transformation - ingredients must be malleable to survive but pungent enough not to be overpowered by others. Given the instances of intra-state conflict reigniting, it is obvious that the struggle for political power during the paused conflict context is where the fight for sustainable peace really begins (and can end) and where exhaustion and identity dynamics can assist or alternatively, destroy the process. The implication of forced constitutions, sham constitutions, inflexible constitutions, the realist's view of constitutions or the minimalist view (frequent and fair elections, freedom of speech and the press) should be apparent. Without learning being translated into constitutions, post-conflict societies cannot practice constitutionalism.

\section{ii) Uganda: constitution making after independence}

Uganda was put under British rule in 1895. The independence constitution paid no notice to the society's traditional institutions, different ethnicity, customs and values, and especially, tribal and religious loyalties. Not surprisingly, it was replaced in 1966 and again in 1967 under Milton Obote. The practice of constitution-making in the 1960s Uganda was not tied to the processes of learning. There was no domestic tradition that had absorbed the lessons from the struggles akin to those between the English Parliament and the monarchy in the $17^{\text {th }}$ century, the associated gradual evolution of an independent judiciary, or the society-wide changes that the industrial revolution produced, including the demand for universal adult suffrage and fair working conditions (Ladley 2010). Instead, it was independence, the uncontainable demand for it, which consumed Ugandan political leaders during this time.

Ugandans suddenly had to begin the process of remaking their own history, learning their own lessons and capturing contested histories in a succession of remade constitutions. A mere three years after independence Prime Minister Obote suspended the constitution, overthrew the constitutional role of the King of the Buganda, made himself both president and prime minister, and abolished all the semi-federal kingdoms that had been part of Uganda's tribal history. This led to an authoritarian presidential system and the "hell on 
earth" (Furly and Katalikawe 1997: 243) which was Uganda during the 1970s and 1980s - a period characterised by the ruination of economic and social institutions; Idi Amin's reign of terror under which many innocent people were murdered and tortured; a series of coups bringing about unstable and short-lived government; and at the same time, a war, in which the National Resistance Army (made up mainly of young men and child soldiers) ultimately triumphed bringing Yoweri Museveni to power.

Uganda's fourth and current constitution (1995) should have reflected the lessons of postindependence. In being mindful of the past, the newly formed political party - the National Resistance Movement (NRM) - wanted to produce a "good constitution", to both validate their coup for the benefit of all (not a small group) and solve the country's political, economic and social problems (Furly and Katalikawe 1997). The emphasis placed on mass participation and widespread consultation, whereby a Constitutional Commission toured the country, educating people on constitutional issues as well as consulting, listening and receiving their memoranda, prolonged the process (four years in total). Accusations that this approach was a way to ensure that the NRM stayed in power for as long as possible were heard (Furly and Katalikawe 1997: 252). Some truth in this may have been proven by future events, but at the time, the NRM's approach to constitutionalism was unprecedented not only in Uganda's history (Waliggo 1994: 22) but for that matter in Africa (with the exception of South Africa) and maybe even further afield (some parallels could be drawn with the Canadian enactment of the Charter of Rights).

Was it learned constitutionalism? The constitution did reflect learning in the preservation of human rights and particularly the protections afforded to women (art 33), in the constitution's permanence, and the limits placed upon executive power. However, like other African leaders who came to power after conflict in the 1970s and 1980s, believing themselves indispensable to their country's national development, therefore, requiring an indefinite rule, nearly a quarter century later Museveni is still the President (a position he will contest again in 2011). ${ }^{71}$ Uganda is a one-man-ruled state, part democratic, but

\footnotetext{
${ }^{71}$ A growing genre of "post-colonial autobiographies" on the lives of key leaders like Mandela (Lee Kuan Yew, Gandhi, Marcus Garvey, Joseph Ephraim, Casely Hayford, Jawaharlal Nehru, Kwame Nkrumah) are written about as part of the history of government and country. The deep connections between the writing on individual lives and the narratives of nations emerging from colonialism, Holden argues has had
} 
mostly authoritarian (patronage system, army at personal disposal, intimidation of the courts and media), with no real pressure from international parties or donors, and no strong united opposition (mainly due to the ban on multi parties which was only lifted in 2005) or civil society to force change - unlike that clearly evident in the succession politics of Ghana, Kenya and Zambia. Museveni has forgotten his own learning. Shortly after being elected President in 1986, he observed that the: "problem of Africa in general and Uganda, in particular, is not the people but leaders who want to overstay in power" (quoted in Tangri and Mwenda 2010: 31-32).

\section{ROMANTICISING CONSTITUTIONS}

In common with Uganda's experience, many post-colonial constitutions were quickly replaced in an array of experimentation with authoritarianism, one-party states, presidential systems, military government and socialism. Some of the independence constitutions endured remarkably, such as those of India, Malaysia, Papua New Guinea and much of the Pacific (Widner 2008). However, over 200 new constitutions were signed in the thirty year period between 1975 and 2005 in countries at risk of internal violence (East Timor, Rwanda, Cambodia, the Comoros, Bougainville, and in the Balkans). The most recent wave of constitution-making has been prompted by the stabilisation/peace processes employed in fragile or conflict-torn states, many of which are in Collier's Bottom Billion (2007) - those states that are in trouble for reasons of poor governance, resource curse, geography or simply bad luck. All this effort has sparked scholarly interest in post-conflict constitution-making, not surprisingly. This will not be the last wave; many of these constitution-making processes are ongoing (i.e., Fiji, Zimbabwe, Somalia, and Nepal) and future events may well precipitate unexpected results -as September 11 2001, for example, did with military action in Afghanistan and Iraq, and two new constitutions.

Post-conflict constitution-making however, has the tendency to promote model solutions rather than learn and adapt to the richness of each new national, cultural, political, and temporal context. As Tushnet (1999: 1330) notes: 
Under the pressure of time and the need for political compromise, a constitution's drafters are likely to latch on to whatever solution is near at hand to the immediate problems they face. They will not have sharp understandings that the institutions they are creating have some necessary characteristics flowing from the very nature of the institutions. With respect to details, they are, in short, bricoleurs.

As a result, constitution-makers tend to turn to history for models to follow, ideas to plunder and rely on international guides or experts. Replication is inevitable to some extent, but this propensity undermines the very goal of attempting to re/construct a particular society through learned, constitutional change.

At the most basic level, constitutions are documents setting out principles by which a society is to be governed. The negotiation of a meaningful, social contract, accompanied by a mind-shift away from war and winning is another matter. This raises the question of whether too much is expected of constitution-building? It is possible that the western perspective on constitutions is a product of its own history and a dose of romanticism.

The American and French transitions of the eighteenth century gave birth to modern constitutionalism, and more than two hundred years later every country in the world, with the exception of Israel, New Zealand and the United Kingdom (although arguably this has changed somewhat with the Human Rights Act 1998 incorporation of the European Convention on Human Rights 1950 in UK domestic law), boasts a written constitution on the basis of the Enlightenment faith in modern constitutionalism.

\section{i) America's Independence Constitution - an evolution}

The American experience was a much less defining break than the rupture characterising the events which happened in France. Protestant interpretations of the Judeo-Christian tradition that were first secularised into political compacts and then incorporated into constitutions and bills of rights (Lutz 1988). The Constitution may have been born of revolution, but it was "well-heeled" one at that (Craven 2004: 10). The records from the period, such as the Federalist papers, show the key American political leaders were consciously trying to absorb the received lessons of the past, including ancient constitutional battles - the Magna Carta 1215 and Bill of Rights 1689 (UK) - and the pathologies of political power under other forms of government. Locke's (1680-1690) inalienable rights of all humans and associated limits on political power, for example, 
were used to critique the British government's failure to respect justified revolution. Comparative political science was also scrutinised, from Machiavelli, Harrington, Montesquieu, Hume, ${ }^{72}$ to the Scottish social and economic theorists -Smith, Ferguson and Millar (Lutz 1984, 1988; Richards 1989). ${ }^{73}$

The Declaration of Independence 1776 and the Articles of Confederation 1777, outlining how the national government would operate can be seen as American's first national compact. Immediate battles with the British provided ground for learning. The rejection of the British parliament's attempts to tax them (even if the British had mounted hugely expensive military campaigns in North America against the French), was not simply based on the desire for independence, but because taxation violated the common law principles fundamental to both the legitimacy and proper interpretation of the British Constitution. Of paramount significance were the 17th century arguments of Lord Coke in relation to the tyranny of King James I, and the common-law principle of "no taxation without representation", which was argued to have equal application to parliament as to the monarchy (Howard 1968: 139-50; Richards 1989). The failure of the Articles of Confederation to limit oppressive state power and grant central government essential powers for governance (Rosenn 1990: 3) were also at the forefront of the new experiment. While forward looking in agenda, the process was grounded in history, and the goal was clearly to establish a peaceful process to make governance decisions in the new polity a goal that has been echoed in almost every preamble of a constitutional document ever since, including the UN Charter.

During a momentous constitutional reflection process, one of the most creative and significant periods of constitutionalism in the modern period, the American experience

\footnotetext{
${ }^{72}$ Machiavelli's (1469 - 1527) Discorsi sopra la prima deca di Tito Livio (commonly referred to in English as The Discourses) outlines his republican thought and guided the constitutional framers. James Harrington (1611-1677) in The Commonwealth of Oceana believed a strong middle class was best for stable democracy - "the doctrine of balance" - and that revolution was a consequence of the separation of economic and political power. His ideas are said to have been partly responsible for the direction taken in the US: written constitutions, bicameral legislatures, and the direct election of the president. Hume (1711 - 1776) had strong ideas on human nature and the corruptible beast that is political power and therefore was a strong advocate of federalism. The authors of The Federalist were overwhelming Humean in their epistemology of political science, although his ideas later fell out of favour, particularly with Thomas Jefferson. Montesquieu (Charles-Louis de Sécondat, Baron de Montesquieu - 1689 - 1755) articulated the separation of powers' theory in his 1748 L'Esprit des lois (usually translated as The Spirit of the Laws).

73 Smith's, Ferguson's and Millar's later developments in political science, along with Hume's and Montesquieu's made Americans more skeptical of the continuing utility of the classical republican models that Machiavelli and Harrington had admired - particularly the classical republics of Rome and Sparta.
} 
was not without a struggle. It did not even start in 1787 or indeed end there. A product of conflict between some of the colonists and the British, the "revolution" itself was strictly speaking a liberation struggle. Constitution identity was consolidated only after the Civil War (1861-1865) and conflict amongst the colonialists (sometime referred to as the second American Revolution) (Richards 1992: 577). The Bill of Rights was not inserted until 1871 (comprising the first ten amendments).

The original constitutional text was not the epitome of revolutionary democracy it is sometimes idealised to be. The constitution entrenched southern slaveholding power through the "three fifths" clause which granted the southern states greater representation and influence. ${ }^{74}$ This was bolstered by the slave importation clause, ${ }^{75}$ which barred Congress from banning the importation of slaves until 1808 by not providing an express power to free the slaves; and the fugitive slave clause ${ }^{76}$ which prohibited harbouring and protecting, so that slaves who had escaped and made to the 'safety' of a free state could be returned or reclaimed by their owners. The core constitutional identity, encapsulated in "all men are created equal", ${ }^{77}$ was not fully deployed until the abolition of slavery in $1865,{ }^{78}$ some 76 years after the constitution's enactment. ${ }^{79}$

The constitution established a democratic form of government based on popular sovereignty; it did not however guarantee the right to vote, leaving this up to the states. White property-owning males were the sole enfranchised group in all but five of the states. ${ }^{80}$ Perceptibly, it was also only after the abolition of slavery that the constitution

\footnotetext{
${ }^{74}$ US Constitution 1787, Article 1, s2(iii) which declared that the slave population was to be counted at 60 percent and added to the number of free citizens in a particular state to count towards representation in Congress. See: Paul Finkelman, An Imperfect Union: Slavery, Federalism, and Comity (Chapel Hill: University of North Carolina Press, 1981), and 'Garrison's Constitution: The Covenant with Death and How It Was Made', Prologue: Quarterly of the National Archives and Records Administration, 32 (2000), 23045.

${ }^{75}$ US Constitution 1787, Article I, Section 9, Paragraph 1.

${ }^{76}$ US Constitution 1787, Article IV, Section 2, Paragraph 3

${ }^{77}$ US Constitution, Paragraph 2

${ }^{78}$ US Constitution, Thirteenth amendment

${ }^{79}$ Condemnations of slavery exist. Madison for example, identified group political psychology based on race as one of the worst forms of faction: "the most oppressive dominion ever exercised by man over man." Speech by James Madison (June 6, 1787), in Max Farrand (ed.), The Records of the Federal Convention of 1787 (New Haven: Yale University Press, 1966) at 134. For a comprehensive account of attitudes towards slavery see: John P. Kaminski (ed.), A Necessary Evil? Slavery and the Debate over the Constitution (Madison: Madison House Publishers, 1995).

${ }^{80}$ Georgia, New Hampshire, North Carolina, and Pennsylvania had restrictions based around whether one paid tax. Vermont was the only state (territory) to extend suffrage universally to every adult male without qualification. See: Willi Paul Adams, The First American Constitutions: Republican Ideology and the
} 
was amended in 1870 to provide voting rights for adult black males and a further fifty years before it was amended to apply to women. ${ }^{81}$ From time to time, Americans have been willing to make minor changes to the constitution but only in the civil war were they prepared to make major alterations. The Constitution is "successful" because it enjoys wide respect and obedience. Federal and state courts have played important roles in making the rule of law meaningful through their decisions, which have in turn almost always been carried out by federal and state executives, even the president. ${ }^{82}$

Further evolution can be seen in the judicial action from the $20^{\text {th }}$ Century to provide equal protection at the state level to many (but not all) of the rights 'guaranteed' in the Bill of Rights, through a process of interpretation of the $14^{\text {th }}$ Amendment. While conventional wisdom maintains this amendment has been a major success - with the equal protection clause providing the basis for the constitutional revolution that ended racial segregation and paved the way for equal rights for both women and African Americans - its very nature has been one of gradual explication of its meaning.

Most of the positive developments can be seen in the post-1950 period - such as the desegregation of the South, the incorporation of the Bill of Rights, the protection of fundamental rights such as reproductive freedom ${ }^{83}$ - but the Supreme Court also institutionalised rigid levels of scrutiny into constitutional jurisprudence and therefore effectively limited judicial oversight to only a few areas. Some argue that the promise of the $14^{\text {th }}$ amendment has gone largely unfulfilled. Perhaps the greatest tragedy was the

\footnotetext{
Making of the State Constitutions in the Revolutionary Era (Lanham, Maryland: Rowman and Littlefield Publishers Inc, 2001) at 315-31.

${ }^{81}$ US Constitution, Fifteenth and Nineteenth amendments

${ }^{82}$ In Cooper v Aaron 358 US. 1 (1958) the Supreme Court rules that states were bound by their decisions and could not chose to ignore them. In 1973 they ruled on what states could and could not control with regards to abortion (Roe $v$ Wade 410 US. 113 (1973)), on the practice of segregated schools in certain states (Brown v Broad of Education 349 US. 294 (1955)) and directed President Nixon to turn over tapes that contained information which ultimately cost him the presidency, in effect ruling that the president is not above the law (see United States $v$ Nixon 418 US. 638 (1974)). They also allowed the publication of purloined Vietnam War documents that made up the "Pentagon Papers" which the Nixon government alleged would endanger national security (New York Times Co. v United States 403 US. 713 (1971)) and directed the return of a steel mill confiscated by the president because a proposed strike would interfere with preparation for Vietnam (Youngstown Sheet \& Tube Co. v Sawyer 343 US. 579 (1852)). More recently in Boumediene v Bush 553 US. 723 (2008) the court ruled that detainees held at Guantanamo Bay as unlawful combatants could seek habeas review of their designation before a civilian court.

${ }^{83}$ Brown v Board of Education 347 US 483 (1954) held that the "separate but equal" doctrine had no place in public education; the incorporation of most of the Bill of Rights during the 1950s and 1960s in cases such as Duncan v Louisiana 391 US. 145 (1968); and the decision in Griswold v Connecticut 381 US 479 (1965) which upheld married couples' privacy right to use contraception.
} 
interpretation in Plessy v Ferguson, which held that laws separating the races were constitutional (Chemerinsky 1992). ${ }^{84}$

Through romantic nationalism, the US constitution-making experience, and many that followed, with all its complexities has been condensed and repackaged out to current situations. The key lesson actually, is that the US Constitution evolved and endured - the framework established allowing for ongoing learning and adjustment (i.e. the Philadelphia Constitutional Congress of 1787, the ratification process of 1791 , the amendments, the establishment of the Supreme Court 1805 , judicial action in the $20^{\text {th }}$ century ), in which the key institutions and actors have 'negotiated' and 'learned' ever since. Slavery and the secession of the South, however, challenged that framework and had to be settled by war.

\section{ii) BiH: the rose-tinted glasses' view of constitution-making}

In the aftermath of WWII, the UK and its dominions offered hope - Westminster democracy was a living reality in Canada, Australia and New Zealand at a time when Germany, Austria, much of Latin America, and even the United States' Supreme Court, had been left reeling. Ackerman (1997: 772) observed: "It was their culture of selfgovernment, their common sense and decency that distinguished their evolving commitment to democratic principles - not paper constitutions and institutional gimmicks like judicial review". This culture developed over centuries and was then successfully transplanted through settlement to foreign shores such as New Zealand. The USA constitution-making process, along with the British, therefore, looks analogous in key respects to many learning processes that followed.

However, the danger in romanticising constitutions is nowhere more vividly apparent than in the case of $\mathrm{BiH}$. After the breakup of former Yugoslavia, the three-year, civil war in the territory of BiH ended with the 1995 Dayton Peace Agreement. ${ }^{85}$ Often cited as a

\footnotetext{
${ }^{84} 163$ US 537 (1896).

${ }^{85}$ General Framework Agreement for Peace in Bosnia and Herzegovina with Annexes, Dec. 14, 1995, 35 I.L.M. 75. This is an international treaty between the three neighbouring ex-Yugoslav states of Croatia, the Federal Republic of Yugoslavia (Serbia and Montenegro since 2003) and the Republic of BiH. The annexes are mainly agreements between the Government of $\mathrm{BiH}$ and the two entities that constitution the state: including the constitution (no.4), the human rights' regime for the state (no.6), the repatriation of refugees (no.7). Surrounding this, but not strictly speaking formally a part of the Agreement, is a plethora of other
} 
classic example of consociational power-sharing among the dominant ethnic groups in the country - the Bosniaks, ${ }^{86}$ Coats and Serbs. The aim was to create a weak central government and give significant authority to the two, ethnically distinct, regional bodies, later confirmed as the Federation of $\mathrm{BiH}$ (the Federation) for the Bosniaks and Coats and Republika Srpska (RS) for the Serbs (art 2 and Mansfield 2003: 2057). Although the constitution designated an overarching, sovereign state incorporating the three groups, the entities own constitutions give them wide powers of regulation and enforcement over the kind of laws that affect their citizens. Only those legislative functions that touch upon BiH's international obligations is reserved by the centre (Szasz 1997: 2062)

In retrospect, many commentators believe the Dayton Agreement is flawed (Aolain 1998 ; Szasz 1997); a "disaster" (Szasz 2000: 298); "Perhaps most damning to the consociational project are the incentives to validate and reinforce the ethnic cleansing of the Civil War period by this ethnic assignment of power" (Issacharoff 2004: 1887). The entities with their own ethnic and religious power distribution have tied citizenship and political rights to ethnicity. The RS's own constitution originally opened with a preamble (later amended, see below):

Starting from the natural, inalienable and untransferable right of the Serb people to selfdetermination on the basis of which that people, as any other free and sovereign people, independently decides on its political and State status and secures its economic, social and cultural development;

Respecting the centuries-long struggle of the Serb people for freedom and State independence;

Expressing the determination of the Serb people to create its democratic State based on social justice, the rule of law, respect for human dignity, freedom and equality;

... Taking the natural and democratic right, will and determination of the Serb people from Republika Srpska into account to link its State completely and tightly with other States of the Serb people ....

It continued by declaring itself a "[s]tate of Serb people and of all its citizens" (art1(1)). The constitution ensures that the official language is Serbian and while article 28 "guarantees" freedom of religion, it specifies that "[t]he Serbian Orthodox Church shall

arrangements between the US and European states (the sponsoring states) including arrangements for the High Representative and various UN documents.

86 This group originally called themselves Muslims but changed to "Bosniaks" or "Bosniacs" later on. 
be the church of the Serb people and other people of Orthodox religion". The State also materially supports the church and "co-operate[s] with it in all fields and in particular, in preserving, cherishing and developing cultural, traditional and other spiritual values." There is no mention of Islam or Catholicism, the religions of other groups. This is a constitution which falls into the first model discussed early - the nation state - creating a governance order based on the homogeneity of the Serbian population, or in other words, exclusion of the others.

For any non-Serb to return to their pre-war home in the territory of RS, they must accept permanent subordinate status in the Serb dominated ( $88 \%$ of the population) and controlled entity. Only Serb members of the state-common institutions are elected from RS and, therefore, a non-Serb could not represent the people or meaningfully participate in the electoral or democratic processes in that entity. The same pattern with reserve ehtnicities is true for the Federation. Ethnic assignments of power it seems, have been used to settle historical scores. During the civil war, the Serb population in the territory went from $54.3 \%$ to $96.8 \%$ and the Bosniak population fell from $28.8 \%$ to $2.2 \%$. ${ }^{87}$ The $\mathrm{BiH}$ Constitutional Court later found:

[A]fter the Dayton-Agreement came into force, there was and is systematic, long-lasting, purposeful discriminatory practice of the public authorities of RS in order to prevent so-called "minority" returns either through direct participation in violent incidents or by abstaining from the obligation to protect people against harassment, intimidation or violent attacks solely on the ground of ethnic origin ... ${ }^{88}$

Within the common institutions of the national state of $\mathrm{BiH}$, the pattern ethnic control being linked to political authority is replicated. ${ }^{89}$ All common institutions are governed

\footnotetext{
${ }^{87}$ Historically the majority of Yugoslavia's population were Serbs, mainly residing in the poorer southern areas of country. They were dominated by the Turks, and later by the more economically advanced Croatian and Slovenian populations in the northern parts of the country. Request for Evaluation of Constitutionality of Certain Provisions of the Constitution of Republika Srpska and the Constitution of the Federation of BiH, Case U 5/98-11I, Partial Decision of July 1, 2000, para 131

88 Constitutional Court of Bosnia and Herzegovina, Request for Evaluation of Constitutionality of Certain Provisions of the Constitution of Republika Srpska and the Constitution of the Federation of BiH, Case U 5/98-11I, Partial Decision of July 1, 2000, para 95 http://www.ohr.int/dwnld/dwnld.html?content_id=5853 89 According to its constitution, the centre remains responsible for the development of "trade, customs, monetary, immigration, asylum and foreign policy, the financing of the state institutions and their international obligations, international and inter-entity criminal law enforcement, operation of common and international communications' facilities, regulation of inter-entity transportation, and air traffic control". $\mathrm{BiH}$ Constitution, art 3 (1). All other governmental functions and powers are delegated to the entities (art $3(3))$
} 
by tripartite executives made up of the same recipe - an equal division of Serb, Bosniak and Croat - and where the checks and balances are honed to a fine degree. For example, the presidency consists of three representative members who rotate the position of the chair (art 5). An "executive impasse" (Mansfield 2003: 2058) can occur whenever a particular decision is seen to be "destructive of a vital interest of the entity from the territory from which he was elected" $(\operatorname{art5}(2)(d))$. Vital interests are not defined. Perhaps euphemistically it means where group interests are threatened, legitimately or otherwise. Ethnic power distribution (art 4(1) and (2)) cause similar problems in the Upper House of Peoples and the Lower House of Representatives of the bicameral Parliamentary Assembly (see: Morrison 1996; Szasz 1997). The practical reality is that almost every important issue is deadlocked (McMahon and Western 2009: 73). The end point of disagreement is a referral to the Constitutional Court.

The Constitutional Court is the sole exception to the ethnic paralysis of post-Dayton and is entrusted to uphold the constitution (art 6(3)) and to decide on disputes arising under it (art6(3)(a)). An ethnic impasse is avoided through three of the nine members being foreigners. ${ }^{90}$ Without any pre-learning, the court has become the forum for challenging the constitutionality of the Dayton Agreement itself. ${ }^{91}$ Focusing on the original preambles of the constitutions of the entities, ${ }^{92}$ the court held:

\footnotetext{
Segregation is, in principle, not a legitimate aim in a democratic society. It is no question therefore that ethnic separation through territorial delimitation does not meet the standards of a democratic state and pluralist society as determined by...the Constitution of $\mathrm{BiH}$... Territorial delimitation thus must not serve as an instrument of ethnic segregation, but-quite the contrary-must provide for ethnic accommodation through preserving linguistic pluralism and peace in order to contribute to the integration of state and society as such (para 57).
}

\footnotetext{
90 See Articles 6(1)(a) and (b); the three members are selected by the President of the European Court of Human Rights "after consultation with the Presidency", and cannot be citizens of any neighbouring country.

${ }^{91}$ Constitutional Court of Bosnia and Herzegovina, Request for Evaluation of Constitutionality of Certain Provisions of the Constitution of Republika Srpska and the Constitution of the Federation of BiH, Case U 5/98-11I, Partial Decision of July 1, 2000. This case was brought by Bosniak Alija Izetbegovic, the then chairman of the Presidency of Bosnia-Herzegovina . Izetbegovic had objected strenuously to the final form of the Dayton Accords as hammered out by Serbian President Milosevic and Croatian President Tudjman. Ultimately, however, Izetbegovic was forced under pressure from the US. to accede to the ethnic assignment of power through the territories. See: the account of the US Ambassador: Richard Halbrooke, To End a War (New York: Random House, 1998) at 308-09.

92 Partial Decision, The Constitution of the Federation of Bosnia and Herzegovina similarly provides that "Bosniacs and Croats as constituent peoples... [act] in the exercise of their sovereign rights."
} 
The legacy of Dayton was then directly addressed:

It is beyond doubt that the Federation of Bosnia and Herzegovina and Republika Srpska were - in the words of the Dayton Agreement on Implementing the Federation, signed in Dayton 10 November 1995 - recognised as "constituent Entities"...But this recognition does not give them a carte blanche! Hence, despite the territorial delimitation of Bosnia and Herzegovina by the establishment of the two Entities, this territorial delimitation cannot serve as a constitutional legitimation for ethnic domination, national homogenisation or a right to uphold the effects of ethnic cleansing (para 61).

The Court has therefore interpreted the Dayton Agreement as having tried to facilitate the re-establishment of the multi-ethnic state existing prior to the civil war. However, the ruling and subsequent striking down of the entities' preambles was cautious and did not rule on the repatriation of ethnic refugees. The Court declared all people equal and upheld individual rights, but did not reject the obvious special collective rights which in effect create powerless minorities in each entity. This cautious judgment is compounding further, as the former president of the Constitutional Court, Kasim Begic (2000), confirmed, by the participation of foreign judges. This provides a guarantee of independence, but the court was still clearly divided with a five (foreign and two Bosniak Judges) to four votes (Serb and Croat dissenting).

There is no agreement on an imagined future on $\mathrm{BiH}$. Of the three groups, only the Bosniaks want a democratic, united, majority-ruled, centralised state. The Serbs reject any notion of a common state (Szasz 1997: 762). The world community favoured the single-state model with no change in boundaries which largely overlaps with the Bosniaks' position, except that the international parties were willing to settle, as has been illustrated above, for an arrangement that would be acceptable, even marginally, to the other two groups (London Conference 1992). Unlike the South African experience discussed below, the different groups were kept apart during the negotiations with an American team moving between them. There was no attempt or indeed opportunity for the groups to see if they agreed upon anything, or even if their understanding of the text was the same. Unsurprisingly none was particularly enthusiastic to enter the foreignshaped arrangements and a number of "carrots and sticks" were offered. In a cruel twist 
of fate, the person representing the Serbians was not even a Bosnian, but the President of Serbia, Slobodan Milosevic. ${ }^{93}$ As Paul Szasz (1997: 764) concludes:

The truth is that they [the groups] were largely bludgeoned and partly bribed into putting their initials and (a few weeks later in Paris) their signatures to texts that none of them had any significant role in developing.

If success is based on ending the civilian slaughter, then the Dayton Agreement and appended constitution were undoubtedly triumphant. However, applying the agreement's own measure of "success", full compliance with its provisions does not exist. Therefore the Office of the High Representative, established in 1995, continues to oversee the "peace" settlement. ${ }^{94}$ International referees were probably the only option to supervise the transition period, but their failure is not an indictment of such measures. Their task is made impossible because the constitution itself does not embody learned constitutionalism or indeed any understanding of groupism. Ethnic segregation, in this case, cannot simply be dismissed as organic, but is partly the product of a legal and constitutional order that has cemented single, identity based groupism into its structure. Critics of Lijphart's power-sharing agreements argue that such measures can only work if groups can cooperate and comprise, and if leaders are committed to maintaining unity (Horowitz 1985; Issacharoff 2004). Nothing in the Dayton process has done anything but generate dissent. The danger of focusing so heavily on the three groups is that tensions and difference among these groups are magnified and exacerbated. And at the extreme end of intolerance is pure racism. ${ }^{95}$ Lijphart (1977: 47-50) himself acknowledges that a government by groups for their groups may water down fundamental rights according to individuals by international law and representative democracy.

\footnotetext{
${ }^{93}$ President Karadžić was banned from the talks after being indicted for war crimes. Of more serious concern for the process however, was the fact that Milošević also represented the then Federal Republic of Yugoslavia, and on many crucial points did not consult with or take advice from the Bosnian Serbs. See: Paul C. Szasz, 'The Dayton Accord: The Balkan Peace Agreement', Cornell International Law Journal 90/3 (1997), 759-68 at 763.

${ }^{94}$ See Article II of Annex 10. The Office can also impose legislation and remove officials who obstruct implementation.

${ }^{95}$ Within the two entities school textbooks have been sanctioned which present historically inaccurate and prejudicial accounts of the conflict. Educational qualifications are not recognized in the other entity. Recent law has eliminated some of these problems by putting in place a universal curriculum and facilitating wider recognition of school certificates. However schooling is still operated in many of the cantons, particularly in the Federation, as a "two schools under one roof system" whereby those children from different ethnic groups either have lessons at different times or in separate parts of the school building. See: Janine Natalya Clark, 'Bosnia's Success Story? Brcko District and the 'View from Below' ', International Peacekeeping, 17/1 (2010), 67-79.
} 
Chandler (2000) believes that the peace process in $\mathrm{BiH}$ would have had greater success if Horowitz's model had been employed. Others argue that the society is so deeply divided along ethnic lines, and an exclusive focus on individual rights at the expense of collective group rights would lead to serious problems, possibly violence (Mansfield 2003: 2084). Of course democratic theory and international law should be flexible with regard to models to further domestic harmony. However in $\mathrm{BiH}$ the strong relationship between ethnicity and citizenship creates perverse incentives and fosters continued segregation through the entities. The only incentive is to move to the entity that represents the respective, ethnic group in order for greater political cohesion, influence and power. The constitution could instead have acknowledged this de facto partition and structured the incentives accordingly (no EU funding unless compliance with minimum standards, refugee repatriation, etc.) or have fostered post-war integration. Indeed, there is one example of this outside of the two monolithic entities: the small self-governing Brĉko District (northeast). Despite being the site of some of the worst war-time violence, today Bosniak, Croat and Serb communities live in relative 'harmony'.

Throughout the rest of $\mathrm{BiH}$, the conflict has simply changed its form, shifting to state institutions - a war by other means. While violence is at least limited, the rhetoric largely remains the same. Unlike the increasingly moderate language evident in Northern Ireland, in the last four years, ethnic chauvinism from the leaders of the three groups has intensified, bringing any hope of reform to a standstill (McMahon and Western 2009). The International Crisis Watch (2010) reported in April of the continuing "provocative" statements of RS Prime Minister Milorad Dodik, including the "peaceful divorce" of the entities. In early 2010, a full fifteen years after the signing of the Dayton Agreements, the RS Parliament passed a law creating a framework for holding an independence referendum. Some interpret this as a test run for Dodik's secessionist goal and certainly the proposal to ban headscarves indicates racial intolerance (see Bancroft 2010; Donahue 2010). Bosniak presidency representative Haris Silajdžić has called for a more centralised state and the dissolution of the RS which he regards as "an undeserved reward for Serbianorchestrated genocide" (McMahon and Western 2009: 70). With the Serbs openly defying the OHR (International Crisis Group 2009), any future Serb withdrawal from state institutions could easily provoke a constitutional crisis. 


\section{iii) Cambodia: empty learning}

In many cases, a glaring gap between constitutions and learning is evident. Cambodia resembles a democratic country on paper, governed by the rule of law and adherence to international human rights' standards. The chapter of the 1993 Constitution entitled, "The Rights and Obligations of Khmer Citizens" (articles 31-50) was included in answer to the "declaration of fundamental rights" required by annex 5 of the Paris Agreement which set out a list of minimum rights for inclusion, as well as a requirement that the declaration be consistent with the Universal Declaration of Human Rights and other relevant international institutions. In other words, ratification of the UN human rights' agreements was on the insistence of the UN and with a high degree of coercion.

Just as the UN (Guidance Note of the Secretary-General 2008, 2009) guidance for constitution-making and the rule of law is formulaic ignoring capacity, the risk of such an approach to human rights is the same: the result - empty mechanisms. The methodology of its enforcement is universally applied even where there is no capacity. In 2005, Human Rights Watch produced its observations on human rights observation progress and political pluralism development (Human Rights Watch 2005: 19, 26). The picture painted was one of political intimidation against opposition parties, independent media and civil society, coupled with a corrupt, incompetent and biased judiciary. The latest Human Rights Watch World Report (2010: 279-81) reiterates disrespect for human rights: almost total control over the broadcasting media, unsolved murders of journalists, criminal conviction of government critics, restrictions on the rights of freedom of association and assembly, arbitrary detention and land confiscations As noted in chapter 4, the UN took a calculated risk in pushing ahead with elections and while the elections were free and fair and enjoyed massive participation the continued flaring of political violence became an excuse for a brief and secretive constitution-making process (Benomar 2004: 84), one in which, the 'losing' side was excluded from the process, and the 'wining' side's flaws were overlooked, which meant that the constitution could not render accountable those responsible for major human rights violations.

A constitution which contains such rights tells one nothing about whether a society has learnt the lessons of the past and will endeavour to have a robust culture of free speech or equality in the future. As Tushnet observes: “...some constitutions are simply 
shams"(1999: 1481). Of course, there will always be a range of acceptable interpretations of rights - reasonable limits prescribed by law ${ }^{96}$, for example, but courts generally provide for independent review. In much of Africa however, many of the problems that have arisen post-independence or post-conflict do not concern the lack of constitutions, but the absence of learned constitutionalism and respect for the rule of law. Constitutional provisions have been: "abrogated, subverted, suspended or brazenly ignored" (Fombad 2007: 3).

The Cambodia example illustrates the wider point that where learned constitutionalism is evident, a social contract is being negotiated, and the process is as important as the provisions. Referring back to Lederach's (1997) integrated model for peace-building, there can be no question of "top-down" versus "grass roots" reforms. To succeed, even if the physical constitutional process is elite (top) driven, it has to be "owned" and "sold" at every level.

\section{AGREEING ON A USABLE PAST AND AN IMAGINED FUTURE}

$\mathrm{BiH}$ illustrates a clear-cut case of the impossibility of learned constitutionalism with an imposed constitution and a top-heavy, paused-conflict process dictated by international actors. It is an inescapable fact however, that constitution-making processes inherently coincide with earth-shattering events: war, defeat in war, reconstruction after war, coup, regime collapse or fear of regime collapse, economic or social crisis which sometimes turns into political revolution, or indeed revolution (Elster 1995; Ginsburg et al. 2009). While non-crisis constitution-making does exist - most recently in Finland and also seen in Sweden's 1972 reform of its 163-year-old constitution - constitutions are rarely written in times of continuous tranquillity in the life of a state but in moments of "political dishevelment" (Scheppele 2008: 1379). It is indeed a paradox. For every example of peaceful transition - such as Spain's move from Franco's dictatorship to constitutional democracy in the mid-1970s and development of a vibrant constitutional culture over the next two decades - the task of constitution-making generally emerges in conditions that are likely to work against it. Constitutions are understood in the literature to be blueprints

96 "As can be demonstrably justified in a free and democratic society". Section 5 of the New Zealand Bill of Rights Act 1990, and Section 1 of the Canadian Charter of Rights and Freedoms. 
- not only to get the state through the immediate crisis - but also to progress the state, as a launching pad for new futures. If written for an indefinite future, they should ideally be adopted in calm and undisturbed conditions, through rational, impartial argument. In turbulent circumstances, passion and self-interest, rather than reason, might prevail.

Kafka's man in the middle from $\mathrm{He}$ - an ambivalent character caught between the past and future, with the risk of group affiliation overwhelming him - is an apt illustration of the predicament of man or society as a whole or indeed, as Arendt used the parable, of the role of constitution drafters, torn by the future and the past (Arendt 1961: 7): ${ }^{97}$

He has two antagonists: the first presses him from behind, from the origin. The second blocks the road ahead. He gives battle to both. To be sure, the first supports him in his fight with the second, for he wants to push him forward, and in the same way the second supports him in his fight with the first, since he drives him back. But it is only theoretically so. For it is not only the two antagonists who are there, but he himself as well, and who really knows his intentions? His dream, though, is that some time in an unguarded moment - and this would require a night darker than any night has ever been yet - he will jump out of the fighting line and be promoted, on account of his experience in fighting, to the position of umpire over his antagonists in their fight with each other.

Political thought, of which constitutional interpretation is a part, arises from living experience and as such, where constitutions have come from the groups' own lessons, they are truly transformative. Strong leadership or mass appeal for change saw success in Bougainville and also in South Africa where members of the apartheid government and the major political opposition groups negotiated core principles encapsulating their learning that were binding on the subsequent, democratically inclusive, drafting of the new constitution. In general, the articulation of learned constitutionalism mechanisms in operation or practice would be evident, not only through the concessions and initiatives in peace agreements or constitutions but also in the language and actions of officials perhaps talking about 'common citizenship' and 'shared responsibility'; in the rhetoric of leaders on their country's national day; in the behaviour of citizens; and in the recognition that violent warfare is no longer necessary, that representation is available in government as a means of being heard.

\footnotetext{
97 This quote is from the last of a series of notes under the title HE. First published in 1946 English translation by Muir.
} 


\section{i) International assistance for local learning}

How learned constitutionalism is assisted is a fraught area. In many post-conflict cases, external states - as sources of external capital and expertise - think external advisors should have input. While sometimes this brings with it benefits of material support, enhanced international credibility for the new government, or the provision of a neutral counterbalance and expertise to domestic interest groups (Bannon 2007: 1866), the risks concern unfamiliarity with local culture and politics. Provisions developed on the advice of external actors may have less standing than purely domestic provisions over which the citizens or political elites feel a sense of ownership, particularly if there is a whiff of external influence serving the interests of an external state.

It is for this reason Feldman (2005) argues it is essential to leave all aspects of responsibility for the constitution to domestic actors as part of the learning process. As the expression of a people's right to self-determination, there has been a clear historical evolution from the imposed constitutions that characterised, for example, the Japanese post-WWII experience and to some extent the decolonisation period, through a period of messy transplantation or borrowing, to a more recent conception, in the literature at least (Guidance Note of the Secretary-General 2009), of constitutions as locally owned and indigenous processes - with much comparative analysis and expertise. The reality is somewhat different (Boege et al. 2008: 15):

\footnotetext{
...donors tend to assume the role of teaching "them" (politicians and people of so-called fragile states) how to do "our" (the western developed donor states') institutions better. "We" tend to impose "our" idea of what a "good state" is on "them" There is much talk of ownership, but often this is not much more than lips service; in effect, locals are supposed to "own" what outsiders tell them to - "local ownership clearly means "their" ownership of "our" ideas"...
}

Dann and al Ali (2006: 423-63) note that international assistance or "influence" can be divided into total, partial and marginal categories. While the aforementioned case of Bosnia was total, at the other end of the spectrum, marginal influence occurs where international expertise is voluntarily sort out by domestic actors, or where inspiration or borrowing from other constitutions occurs, and where there is local ownership of the process and the content of the constitution. Examples of this include South Africa and Eastern European states in the early 1990s. The middle category is somewhere between 
more-than-voluntarily requested but weaker than a foreign takeover. Here the constitution-making process is directed by external actors in a procedural and/or a substantive way. The power of drafting and adoption, however, remains in the hands of domestic actors. The "pouvoir constituant" - the force of the people as a political body creating new order (B. Ackerman 1991) - is not entirely intact but not entirely surrendered.

This middle road appears to be the most common category of recent cases, including East Timor and Iraq, but influence still varies greatly, and outside motives can creep in. The US' main concern in Iraq was to ensure that the constitution's section on human rights would not create a means of claims being brought against US troops in Iraqi courts by locals (Dann and Al Ali 2006: 459). ${ }^{98}$ In the case of East Timor, the United Nations managed the entire constitutional process and were the only case where no allegations have been made concerning the undue impact of external actors on the constitution's substance. Perhaps as a multilateral institution, ${ }^{99}$ the behaviour of the advisors tends to be more balanced.

Procedures established for the drafting and enactment of new or substantially amended constitutions post-conflict should make a difference. However, the reality is that pinpointing what is 'right' in any given constitution-forming context is difficult to boil down in a methodological way. Many have tried to understand the role of international assistance, and while a plethora of best practice guides exists (Guidance Note of the Secretary-General 2008, 2009; V. Hart 2003; Kristi Samuels and Wyeth 2006), there is no concrete answer. Most recently the International IDEA has launched Constitution Building Programme (CBP) to study the practice of constitution building and share

\footnotetext{
${ }^{98}$ Article 44 of the older draft Iraqi Constitution, not that one that was presented for adoption in 2005 even though a similar clause had been in the TAL (art 23), read as follows:

"All individuals shall have the right to enjoy all the rights mentioned in the international treaties and agreements concerned with human rights that Iraq has ratified and that do not contradict with the principles and provisions of this constitution"

Regardless of any "official" reasons for removing this article - that the United States reportedly sought its removal, concerned it allowed the constitution to supersede international treaties - there has been much debate over this move. The analysis from the Carnegie Endowment for International Peace states that: "it undercuts the human rights protections available to individuals" Nathan J Brown, "The Final Draft of the Iraqi Constitution: Analysis and Commentary', (Washington: Carnegie Endowment for International Peace 2005 ) at 2.

${ }^{99}$ However the likes of the IBRD and the IMF with their particular missions, sometimes impress upon the constitution-making process legal and economic mechanisms that would be more advantageous to their membership than the constitution-making society in questions.
} 
insights with national and international actors, in order to strengthen the role constitutions can play in democratic and post-conflict transitions. At best, it is noted that there is no firm view of international assistance and certainly no concrete framework surrounding such activities, a significant gap, which will be returned to in the next chapter (Ladley 2010). The actual physical act of constitution-drafting and enactment is but one stage in the process. International monitoring of constitutional implementation is where the intentional community can provide the best assistance, not unlike election-monitoring, but this would need a clear mandate, in an area that already suffers from the benign but confused and confusing offers of international assistance.

The literature does agree that public participation is crucial (Chesterman 2004b: 211; V. Hart 2003). Legitimacy is as much about process as it is about content. The Agenda for Peace (Boutros-Ghali 1992) saw a clear role for the UN in promoting formal and informal processes of public participation (see also Guidance Note of the Secretary-General 2009). Granted there is no concrete evidence on the effect such processes has in supporting better peace process and plenty of examples where no real change was observed (i.e.,. Eritrea and Ethiopia,) (Ginsburg et al. 2009: 215) or indeed the very activity inflamed conflict (Congo-Brazzaville, Chad and Solomon Islands). ${ }^{100}$ On the other hand no opportunity to participate has meant constitutions are perceived as imposed (i.e.,. in Nigeria, Zimbabwe and Bahrain) (Kirsti Samuels 2007 606). It would seem that part of building immunity to future hiccups in governance and also the requirement of Rawlsian justice - for the social contract - requires voter education. Higher levels of trust and cooperation were undoubtedly observed in Benin and of course South Africa, and this is an area where the international community can offer logistical and financial support.

\footnotetext{
100 Ian Scales argues from observations during his time based on the Western Province island of Kolombangara over 1999-2000 that political aspirations for great independence and thinking towards a federal system of government led to ethnic tension particularly in the West and politicians in the Western Province used the ill-conceived June 2000 Malaitan coup in Honiara to push their federalism preferences. Fukuyama observed that the desire to create a federal system seemed to be pre-empted by the need for better control over service delivery and to control immigration into the territories. See: Ian Scales, 'The Coup Nobody Noticed: The Solomon Islands Western State Movement in 2000', The Journal of Pacific History, 42/2 (2007), 187-209, Francis Fukuyama, 'State Building in Solomon Islands', Pacific Economic Bulletin, 23/3 (2008), 18-34. Ultimately, under the Townsville Peace Agreement of mid-October 2000, the Solomon Islands' government was mandated to introduce a form of government that would give more autonomy to the provinces. Despite facilitation by the UNDP and the drawing up of a new draft Solomon Islands' Constitution, it has not yet been passed.
} 
The form of government, however, is not the concern of internationals. Samoa's determination to "own" their governance system saw them break with the conventional Westminster model, incorporating elements of traditional governance systems and custom. Only matai (traditional chiefs and family title-holders), it was decided, would be allowed to vote and be elected to parliament, ${ }^{101}$ contrary to attempts by the UN to impose universal suffrage. This allowed Samoans to own their 1962 independence constitution and parliamentary democracy from the first, and also the sharing of the head of state duties between the two major contesting traditional leaders. In the current climate, dominated by the formula-state model, it is highly unlikely this would be acceptable to donors and the international community. While occasionally condemned overseas as a violation of the UN Declaration of Human Rights' universal franchise principles (Quentin-Baxter 1987), village-level, electoral competition adjusted to the electoral rules and universal suffrage was introduced in 1990 (So'o and Fraenkel 2005). Human rights' protections came with liberal democracy, and have been absorbed (not always without contest) into the relationship between citizens and the Samoan state, and were further strengthened when Samoa became a member of the UN in $1976 .{ }^{102}$

Context however, is everything. The level of conflict in a particular country, for example, will necessitate quite different types of international assistance. Sometimes without international assistance, self-determination may well be impossible. In other situations, assistance will be rejected outright. While Feldman's (2005) thesis was based on Iraq, other situations may necessitate support being given to voices from wider society in their efforts to be heard and empowered, instead of leaving the process to the particular country's elites. In Bougainville, encouraging the marginalised but powerful groups in society, like women, to express their voice was crucial for getting more people involved (Boege 2006b) and for ownership. Women made powerful displays of protest during the conflict - such as in 1990 when those on the island of Buka challenged a BRA blockade preventing emergency medical supplies being distributed by the PNGDF or the women of Selau in north Bougainville who held 5,000 strong, all-night, peaceful vigils protesting

\footnotetext{
${ }^{101}$ See the Electoral Act 1963 (Samoa). Two candidates are also elected as representatives of naturalised Samoan citizens and Samoans who are of European descent.

102 Occasional conflict between fa'asamoa which upholds the practice of the matai (responsible for upholding social order and leading consensual decision making) can be seen in the 1998 case of the village of Salamum where the matai banished several families for trying to establish alternative religious practices (private prayer sessions) after rejecting the Methodist church.
} 
against the violence (Carl and Sr. Lorraine Garsu CSN 2002: 30). The opening up of markets under the TMG provided women with meeting places. Bodies such as the Provincial Council of Women encouraged and helped in this endeavour (Jaintong 2001) and groups like the United Kieta Women's Co-ord Group (UKWCG) became the cornerstone of peace, health, good living and reconciliation. Jossie Sirivi, (who led BIG women) talks about the importance of the peace being "sold" to others, and believes women played a big part in this (Jossie Sirivi 2001). Realising that Bougainville was traditionally a matrilineal society, the TMG united the two main women's groups Jossie's BIG and Theresa Jaintong's Bougainville Council of Women. Realising the strength in unity, and united in their exhaustion and receptivity to alternative strategies, they could then combat a generation of young men who disregarded their status and treated them poorly. Leaders of women's organisations speaking with one voice ultimately played an important role in the July 1997 Burnham talks held in New Zealand. Bougainvillean women also attended meetings leading to the signing of the Lincoln Agreement on 23 January 1998. The Bougainville Women for Peace and Freedom, an organisation representing women from BRA and BIG, demanded the complete withdrawal of PNGDF from their areas.

\section{ii) Public participation}

Obviously public participation, without learning, without exhaustion and a true mindshift is tokenism. Learned constitutionalism necessitates that elites, representing political forces with significant amounts of power, commit to making the arrangements work after they go into effect. Peace conferences are usual in this endeavour. Similar buy-in from the population generally constitutes one more compact or buttressing element in the process. A referendum is common, an alternative example occurred in a number of countries, including South Africa, and has been admired by many (V. C. Jackson and Tushnet 2006: 287-89). The buttressing of exhaustion and learning requires building in enough "never again-ism" (truth commissions for example), and making believers out of the process (retraining, reorienting, education, jobs, therapy, etc.). Without this - where weak consensus reigns, or where political deals are hatched for short term "fixes" ignoring the involvement of the wider people ${ }^{103}$ - positive and peaceful governance will

${ }^{103}$ A current example is obvious in Zimbabwe, where negotiators are aiming primarily for a political deal in the proposed new constitution - reflecting the short-term interests of the political parties. This goes 
likely not emerge. Where the methodology of changing rules does exist, however, the momentum can push aside those who would rather stick to violence (the splinter IRA groups for example, or those focused on looting the state).

\section{iii) Breaking with the past}

Presuming that all the good-will in the world exists (exhaustion), at the domestic level critiquing the past is a requirement of learning - even that which is shameful and patently unjust. More than mere "debunking" must occur, for the past will not go away and will continue shaping the present and informing the future - through the festering of grievance. Group relationships cannot be mended without this articulation, not just for an imagined future - which is often what a constitution sets out to frame- but also of an understanding of the past. If the very issues or events that caused the inter-group relationships to break down or cleavages to appear (whether real or constructed) are not addressed, reconciliation will not occur. Kreisberg (1999: 107) states: “a fundamental dimension of reconciliation is the truthfulness about the past and the present, open and shared recognition of the injuries and losses experienced".

Like the Rwandan example presented in the previous chapter, interviews conducted in the Brčko District of $\mathrm{BiH}$, a district distinguished from the rest of the country due to its peculiar status as self-governing and multi-ethnic, suggest there is no open talk about the war (J. N. Clark 2010: 71). The past is "taboo". Talk inter-ethnically is gauged in very general terms, for example - war is futile and should never happen again (United Nations Development Programme 2005: 30). This could reflect the lack of chauvinist or nationalist rhetoric in the district, people being more consciously aware of offending others. Avoidance of offence, however, could also be reminiscent of "chosen amnesia". (Buckley-Zistel 2006; 2008: 137):

...aspects of the past seem to be eclipsed from the discourse, creating a form of amnesia, albeit selective... which functions as a coping strategy, a way of maintaining the social equilibrium and of living in a climate of mutual distrust.

against the wishes of Zimbabweans who had hoped for a democratic charter based on learning since independence in 1980, including the need for accountable government and the safeguarding of basic human rights. Zim Online, 'New Constitution, a Damp Squib: Ngos', ZimOnline, Monday 25 October 2010. 
The silence observed in Brčko, supposedly the model of reform in $\mathrm{BiH}$ serves to maintain some form of social harmony and order. The worry is, of course, that not dealing with the past means that history may be doomed to repeat itself. As philosopher and novelist Santayana (1905: 284) said: "Those who cannot remember the past are condemned to repeat it".

Justice and reconciliation must form part of the process of addressing the past - the psycho-social dimensions of conflict are an important factor, and easily overlooked in the rush for western politicians, policy makers, development agencies and NGOs to concentrate on material reconstruction and rehabilitation (roads, schools, hospitals, etc.). Transitional justice can be delicate as amnesties are often used to induce cooperation in peace processes. Equally large-scale purges can deny the state essential human skills. Yet facing up to the past is essential to reconciliation and to the possibility of returning to normal life (if indeed there is such a thing). The notion that abuses will no longer be tolerated, or part of the culture of society must be a clear message regardless of whether amnesties, truth and reconciliation commissions, or hybrid courts are employed. Instruments of transitional justice have been improved upon, the lessons for example from the South African experience, critiqued and strengthened for use in Sierra Leone and East Timor (Brahm 2009; Dickinson 2003; Hayner 1994). Internationally, global justice and the responsibility to protect have evolved to see heads of states face criminal trials. Arguably, therefore, transitional justice serves a role in healing social wounds but also in the transformation of world politics - a transformation interpreted as strengthening the rules of exhaustion. ${ }^{104}$ Fancy processes are not necessarily required. Despite no substantive policing, court or prison system, Bougainville remains one of the safest communities in PNG, due to community-based, justice systems. There emphasis is not on punishment, but on restorative justice, a practice which has existed for thousands of years (Reddy 2008).

\footnotetext{
${ }^{104}$ The institutions of justice and reconciliation are not perfect. Call in particular has outlined the problem with "victor's justice", the impact of the US's patchy support of transitional justice efforts, and the somewhat peacemeal evolution of these transitional justice efforts. Charles Call, 'Is Transitional Justice Really Just?', Brown Journal of World Affairs, 11/1 (2004), 101-13.
} 
The South African experience is a positive example of breaking with a repressive past. A future filled with the hope of freedom was to become the prevailing theme in constitutional interpretation and discourse surrounding it. ${ }^{105}$

\section{iv) South Africa's constitution: "a ringing and decisive break with the past." 106}

South Africa's dire, apartheid-era human rights' record began shifting in the early 1990s with deep changes to social, political and economic structures within the country. Until recently, little was known about one such gathering of key elites from all sides which shaped learning on conflict and governing. The 1993 Mont Fleur scenarios were devised to stimulate debate on how to shape South Africa over the next decade, bringing together 22 leaders or potential leaders (thinkers, key policy makers, business people, politicians, with strength of character and those identified as likely to become future leaders). A set of stories was presented to the participants on what could occur. Three contained warnings of the various ways in which things could go wrong. One was a benign picture of inclusive democracy and growth. The best of the resulting narratives produced around these scenarios were then used to extend the discussion and learning with more groups (political parties, companies, academics, trade union and civic organisations). While the participants were not negotiators, the fact that a substantial number of Mont Fleur participants went on to occupy influential positions in South African produced learning and influence well beyond anyone's imagining. The value of listening and talking openly, in particular, helped: "to shift the economic thinking and acting of the ANC and other left-wing parties and to avert an economic disaster" (Kahane 2004). Mutual understanding was the product, translated from the elite to wider groups, and delivered in church sermons for example.

Further setting this change in motion was the December 1993 agreement to adopt an interim constitution (included an entrenched and justiciable Bill of Rights) authored by the two main political forces, the African National Congress (ANC) and the National

\footnotetext{
${ }^{105}$ See for example, the postamble to the Interim Constitution of 1993: "this Constitution provides a historic bridge between the past of a deeply divided society characterised by strife, conflict, untold suffering and injustice, and a future founded on the recognition of human rights, democracy and peaceful co-existence..." ${ }^{106} S v$ Mhlungu (1995) 3 S.A. 867 (CC) 873
} 
Party (NP). After becoming supreme law in 1994, ${ }^{107}$ the interim framework set out a process for a new constitution.

Although much "borrowing" occurred, a distinctive feature of the South African transition was the relatively modest role played by external advisors. A commitment to the process of constitution-making was evident in the consensus which moved negotiations forward; the recognition of the futility of walkouts or boycotts; the use of informal conferences (bosberaad or bush conference) which facilitated trust and broke down stereotypes; the avoidance of triumphalist rhetoric in favour of compromise; and the refusal to allow spoilers to derail the process (even in light of the assassination of the ANC's Chris Hani or the St James' Church Massacre at Kenilworth) (Hamill 2003).

The constitution that was eventually adopted in 1996 was subject to inspection by the Constitutional Court. ${ }^{108}$ The Court had to certify that the constitution's provisions were substantially in accordance with the 34 constitutional principles agreed upon by the major groups in society at the beginning of the drafting process and then enshrined in Schedule 4 of the interim constitution. ${ }^{109}$ The principles included, among other things, three tiers of government, a multi-party democracy, the separation of powers and broad parameters for devolution of power to the provinces. At the forefront were universal, justiciable and entrenched fundamental rights. This signalled a big change since South Africa had previously been viewed as a "pariah" by the UN and other international bodies and in return South Africa had considered the UN an enemy and paid scant attention to the various decisions and documents originating from it. The apartheid state had dismissed the Universal Declaration of Human Rights as communist propaganda and vilified other declarations and resolutions (Sohn 1994: 63-107; South African Law Commission 1989).

\footnotetext{
${ }^{107}$ For more on this initial process, see: David Welsh, 'Negotiating a Democratic Constitution', in J.E.Spence (ed.), Changes in South Africa (London Royal Institute of International Affairs, 1994), 25. The task of constitution-making was delegated to a 46 member, proportionally represented, constitutional committee of MPs who were in turn divided into a number of committees focusing on different aspects of the constitution. These committees were supported by a secretariat and expert constitutional advisors. The assembly devoted time and energy to soliciting the views of all South Africans and to communicating their progress and work back to the people.

${ }^{108}$ Ex parte Chairperson of the Constitutional Assembly In re Certification of the Amendment Text of the Constitution of the Republic of South Africa [1997] 2 SALR 97 (CC), 162. The foundation members of the court included: an international war crimes prosecutor - Justice Richard J Goldstone; former law professors - Justices Yvonne Mokgoro, Kate O'Regan, and Albert Louis Sachs; and the attorney who founded the nation's leading civil rights litigation firm and represented Nelson Mandela during his imprisonment Chief Justice Arthur Chaskalson.

${ }^{109}$ South African Interim Constitution, Schedule 4, Part 5.
} 
The new constitutional framework protecting individual rights arose from the strength, but also the suspicion, of the old order during the negotiating process; the adherence of the ANC to the notion of fundamental rights; and the strong belief held by many South Africans that ethnicity and division ought not to be a part of the post-apartheid state. These were crucial to securing the acquiescence of the minority, largely white parties. The principles provided a set of constraints and guidelines for the writers of the permanent constitution. ${ }^{110}$ Among these was principle 14 - “[p]rovision shall be made for participation of minority political parties in the legislative process in a manner consistent with democracy" - which assured the white minority that democratic rule would not simply be an invitation to majoritarian retribution. As Issacharoff (2004: 1876) explains:

Whatever the historical merits of retribution, and whatever the grave injustices of apartheid rule, the fact remained that without some formal guarantee of security, power would never be ceded except on the closing end of a bloody civil war.

An independent arbiter, in the form of an independent judiciary, was agreed upon to strengthen the security provision of the constitutional principles. ${ }^{111}$ The creation of the Constitutional Court resolved the impasse over the problem of the constitutional compromise being unelected architects, which, while this could be overcome through the final constitution being adopted by a properly mandated body, ${ }^{112}$ the insecurities of the various groups might not be sufficiently addressed and, therefore, they might subvert the

\footnotetext{
${ }^{110}$ A full list of constitution principles contained in Schedule 4 of the Interim Constitution can be found here http://www.constitutionalcourt.org.za/site/constitution/english-web/interim/schedules.html\#sched4 ${ }^{111}$ When debate began over the need for a Constitutional Court, it was felt that many of the apartheid-era judges were unsuited as the new power of judicial review would allow a partisan and insulated minority to overturn the law enacted by the majority. See: Johan D Van De Vyver, 'The Randolph W. Thrower Symposium, Comparative Constitutionalism: Constitutional Options for Post-Apartheid South Africa', Emory Law Journal 40 (1991), 745-834 at 802-04. Four existing judges were appointed, from the more progressive side of the existing judiciary. By the end of 1996 as the new constitution was enacted, the new court had decided around forty cases with decisions in many cases being a triumph of human rights and democracy: for example, the abolition of capital punishment as this violated the right not to be subject to torture of any kind; and the ruling that the state generally bears the onus of proof in criminal cases. Crucially on issues outside of human rights - on the power of provincial government not controlled by the ANC, the court was seen to "be making decisions without fear or favour". See: Jonathan Klaaren, 'Executive Council, Western Cape Legislature V President of the Republic of South Africa', South African Journal of Human Rights, 12 (1996), 158-62 at 159.

${ }^{112}$ A two-stage transition was employed. An interim government governed through a coalition while the constitution was being drafted. A national legislature elected by universal adult suffrage, would then double as the constitution-making body tasked with drafting the new constitution within a certain timeframe.
} 
objectives of a negotiated settlement. ${ }^{113}$ The Constitutional Court assumed the mantle of the ultimate arbiter of the constitution, holding full powers of judicial review. Prior to 1994, the South African Parliament was completely sovereign with the courts only having a procedural review over laws adopted.

After a rigorous process which included submissions from political parties and the public, as well as public hearing, the unanimous 288 page judgment, the Court refused to certify the text of the draft constitution. The Constitutional Assembly was directed to relook at ten sections. ${ }^{114}$ These mainly concerned excesses of majoritarianism. For example, the provision enabling a two-thirds majority of the National Assembly to amend the Bill of Rights was insufficient to ensure that the Bill of Rights would be entrenched, as required by Constitutional Principle 2. The court also rejected the notion that judicial review could not be used for certain categories of statutes, and judicial review was unsurprisingly affirmed as a commitment to constitutional supremacy and jurisdictional guarantees for judicial power in Principles 4 and 12.

The constitutional principles could not guarantee the future, but they did provide a process and framework within which areas of commonality were defined and differences located. Some have argued that for the former NP government the principles guaranteed the survival of the old order, that they were willing to transfer some power to the ANC; "so long as the resulting state would have substantially inferior powers compared with those of its predecessors" (Mutua 1997: 81). This misses the point. Although the comparison to the past is valued, in post-apartheid South Africa, the successor government would obviously have less power if any learning had been done. Without such constitutional constraints, a racial civil war would have been inevitable - remembering of course that the white minority, while they may not have been able to overcome the ANC, still controlled the military. What materialised through thorough negotiation was the realisation that the rules of the game had to be, in the future, fair for all parties concerned.

\footnotetext{
${ }^{113}$ In the words of the Constitutional Court: "The government and other minority groups were prepared to relinquish power to the majority but were determined to have a hand in drawing the framework for the future governance of the country. The liberation movements on the opposition side were equally adamant that only democratically elected representatives of the people could legitimately engage in forging a constitution: neither they, and certainly not the government of the day, had any claim to the requisite mandate from the electorate." In re Certification of the Constitution of the Republic of South Africa, 1996 (4) SALR 744, 779 (CC).

${ }^{114}$ Ex parte Chairperson of the Constitutional Assembly: In re Certification of the Constitution of the Republic of South Africa [1996] 4 S.A 744 (CC).
} 
A successful model was thus created for the transformation of their conflict built around concepts of political inclusiveness, power sharing, and mutual accommodation between former enemies, thus preventing the alternative - an ethnic meltdown of the likes that occurred in Rwanda and BiH. The reality of the ANC's towering, political ascendancy and one-party dominance perhaps eclipses some of the earlier idealism (Hamill 2003: 3). Nonetheless, Nelson Mandela employed an inclusive rhetoric of blame in order to further political transformation, contrasting sharply with Milosovic's 1989 rhetoric invoking collective memories in order to assign blame to others:

We place our vision of a new constitutional order for South Africa on the table not as conquerors, prescribing to the conquered. We speak as fellow citizens to heal the wounds of the past with the intent of constructing a new order based on justice for all. ${ }^{115}$

The Mont Fleur sessions, the interim constitution and the generally slow nature of the progression towards the 1996 Constitution (certainly by the standards of other constitution-drafting examples), defused pressure to finalise governance question which were highly contested. At the same time, a sense of security was conveyed to minority constituencies. While some have more recently criticised the court for playing a pragmatic role in rejecting calls to develop wide rights jurisprudence - deferring to the government to craft policies to achieve those objectives. ${ }^{116}$ Since the court had played a role in creating the fledgling democracy in what was after all still a deeply divided and violent place, it is not surprising that they also showed reluctance to substitute decrees for democratic deliberation and compromise.

\section{THREATS TO LEARNING STABILISING}

Returning to the two models of constitutions outlined above (national-state and liberalprocedural), clearly divided societies are going to struggle to fit into the nation-state box.

\footnotetext{
115 Contrasted too against the recent rhetoric of ANC Youth League President Julius Malema urging the seizure of white farms and fight against what he called Western imperialism.

${ }^{116}$ For a summary of the criticisms - particularly Republic of South Africa v. Grootboom (2001) 1 SALR 46 (CC) in which constitution's guarantee of a right of access to adequate housing did not prevent the court from deferring to "reasonable" measures taken by the state to provide such housing - and a defense of its pragmatism referring to the courts decisions on the death penalty and gay and lesbian equality arguing that "the Court has been pragmatic in selecting only a few cases on which to expend its institutional capital. Mark Kende, 'The Fifth Anniversary of the South African Constitutional Court: In Defense of Judicial Pragmatism', Vermont Law Review, 26/4 (2002), 753-68.
} 
Equally, however, there may be insufficient popular support for the liberal-proceduralist, constitutional approach. Where society is deeply divided, this can still be acknowledged in a flexible constitution. By recognising the limits of concrete legal solutions, controversial decisions are deferred to the people's representatives, the courts or the people through referenda - such as Northern Ireland's or Bougainville's referendum on status $^{117}$ - introducing an element of gradualism instead into the process. Interim constitutions can be seen as part of this continuing evolution. This is not the traditional perception of constitutions as revolutionary moments (B. Ackerman 1991). Some societal consensus is needed to create a shared civil and procedural identity. In Western societies, people hold multiple and overlapping identities. In divided societies, it is important that the constitution does not clash with private identities to promote spoilers or preference of one version of the state over another. Through the integration of the multitude of individuals in a common, safe space, a new, untied collectivity can emerge for paused-conflict governance, a collectivity which will grow and strengthen, perhaps reducing the salience of other identities. The relationship between constitutions and time is paramount. Reining in radical change and instead creating clear stepping stones, moving from the idea of a resolution to providing a framework for transformation, is required. Such an approach does not endeavour to present a homogeneous unity and recognises internal segmentation but on the other hand, it does not attempt to privatise issues of identity by ignoring them and expurgating them from the constitutional arena (Rawls 1996: 151). Learned constitutionalism acknowledges groupism and defers (not ignores) contentious issues so that further learning can take place.

The critical mass necessary for Leviathan to be pacified, should also not be undone by fundamental errors associated, mainly, with reverse-engineering the liberal peace overlooks issues of capacity, foreign concepts, real rules and counter cultures. Enacting constitutions which cannot be effectively protected has been one obvious omission in post-conflict constitution-making. Producing a situation where the pacifying society's expectations cannot be fulfilled makes the learning and rules redundant. In Somalia, for example, the constitution process suggested by Samuels (2007) included civic education

\footnotetext{
117 The Bougainville Peace Agreement of 2001 provided for autonomy within the framework of the PNG Constitution but also provided for a constitutionally guaranteed referendum on the territory's political future in 10-15 years' time. These mechanisms were passed by the PNG Parliament in March 2002 where increasing powers are assumed by Bougainville.
} 
and consultation. However, this was stymied by security realities. There has also been a parallel problem of the wide gap between domestic (localised, clan authority) and international conceptions (central state) of the Somalian state. This is a fundamental problem for the most difficult of post-conflict cases, requiring a change in direction for the international community and the formula-state model. Instead, as the restorative justice example from Bougainville demonstrates, local practices should be supported to provide mechanisms for the learning.

In other settings, such as northern Kenya, traditional forms of justice delivery are more powerful than state institutions, particularly when the institutions that constitute "the state" are physically located far away. In such cases, these "rule-of-law" institutions could become redundant if they cannot adapt and be responsive to what Chopra calls "socioculture contexts" and be more mobile (T. Chopra 2010). The way round this, in the Kenyan case, was state support for declarations encompassing the different traditional conflict resolution mechanisms that groups within the northern region could agree upon. These run parallel to official law. Far from ideal, it suggested that the state rule-of-law exercise has failed, and further problems arise when the two systems contradict each other. In other countries, New Zealand included, indigenous courts or courts for indigenous issues (i.e. Australia) have been integrated into the official state system. Training judges specifically in social contexts (South Africa and Canada) and responding to the social diversity was in the case of South Africa, a way of eradicating the remnants of apartheid.

In Cambodia, corruption is institutionalised, endemic at every level: "constructed and operated on a feudal basis, at the heart of which is the patron-client relationship propagated by elites" (Richmond and Franks 2007: 38). Papua New Guineans "own" elections, they have become part of their culture. However the cheating that occurs across the board is not really relevant; it is accepted as part of the culture. There is no true support for the core values of democracy and no social ceasefire on tribalism and cheating. In such situations, it is impossible to leap into governance but important to promote efficient administration based on a rule of law as well as a basic structure of justice, before vigorously promoting fully fledged democracy where the possibility of marginalisation from power has greater consequences (resources) than in existing liberal states. This kind of approach could have a number of short-term advantages while simultaneously laying 
the foundations for more solid and fully developed democracy in the long run. This approach is acceptable under Rawlsian democratic theory: that certain minimum standards of decency are adhered to in the process (Rawls 1999).

Accepting law as the basis through which to construe social relationships and to resolve conflicts is inherent in the process of learned constitutionalism (Hegel 1967). Pausedconflict governance encounters a major obstacle where there is essentially no rule of law, no habitus of obedience to the law (von Bogdandy et al. 2005). Where real rules and counter cultures dominate in a society, learned constitutionalism will be more difficult, particularly if there is nothing to fall back on. In Yugoslavia for example, the disintegration was a case of both national aspirations (Coat and Serbian) destroying the "habitus" of resolving conflicts peacefully within an existing legal framework and a legal tradition being undermined by decades of communist rule. In other situations, it is not the lack of a common identity or common traditions, that is the problem but the lack of a legal tradition tied to modern statehood. The case of Somalia illustrates this where the society to a significant extent is still constituted along the lines of various clans and subclans from independence in 1960 and through the civil war that raged in the 1990s up to this very moment (Bradbury and Healy 2010).

Depending on the context, tying rule of law and justice to something recognisable has to be the focus. This in turn could assist in reinforcing exhaustion and also addressing groupism. However, strategies that do not pay careful attention to real rules are doomed to failure. $\mathrm{BiH}$ suffered from a post-conflict context where there was a judiciary, but it was not independent. It was already in crisis because of misuse as an instrument of ethnic cleansing during the war. Corrupt judges could not separate themselves from their political and ethnic prejudices, and were overlooking the crimes of known criminals, because of the close relationship between the political power structures and organised crime. Fast-tracked privatisation placed key assets in the hands of local power groups or mafia. 


\section{CONCLUSION}

Post-conflict constitution-making should not be seen as "resolution" in the manner of traditional revolutionary, constitution-formation. To make sense of the fundamental issues facing the paused-conflict state within the non-ideal "out-of-conflict" setting, a gradualism is suggested, allowing for learning to develop. The USA's learned constitutionalism did not happen overnight; it evolved, and is ongoing. In paused-conflict contexts, discussions perhaps akin to South Africa's Mont Fleur sessions, interim constitution periods, the use of traditional systems to deal with conflict or the creation of new reconciliation processes, agreement on basic core commonalities, all take time. Setting aside the controversial decisions that can overwhelm all else (succession, independence, etc.), it is crucial to provide the necessary space to break with the past.

The risk of not allowing space for learning to develop is illustrated by $\mathrm{BiH}$. As a classic example illustrating the danger of the romanticised (and completely inaccurate) interpretation of the "great" modern constitutions, group division has been solidified and strengthened through the constitution and the institutions established. It should be possible to acknowledge groups in constitutional frameworks without creating further division but only where there is receptivity first. Constitutions can codify the prevailing consensus, thus providing the framework for the conflict transformation and the necessary conditions for governance. However, the lessons of learned constitutionalism must continue to be articulated, providing immunity against future threats - for they will surely come. Political elites' capacities for sustaining grievance and conflict are a sad reality of many cases (Fiji, BiH, Cambodia). South Africa was able to lower the stakes for playing the political game.

The practical lesson for current peace processes (everywhere) is that societies emerging from conflict needed processes which involve extended discussions among groups, not only to share power and leadership positions among them (often the key goal of those involved), but to learn their own lessons about the past, in order to imagine a shared future. It is only then that this learning can be institutionalised in ways that work for their cultures, histories and peoples. If sufficient consensus, or a critical mass for change, is to eventuate, all groups must be involved and committed to the peace process. Learned 
constitutionalism inherently has to be a domestic process, but there is room for international assistance. 



\section{7: Appropriate International Assistance}

\section{INTRODUCTION}

The preceding triad of building blocks focused on the primary domestic actors in conflict and the potential of the Leviathan to be pacified. The approach of conflict transformation does not however discount the help and resources of outsiders. International assistance may not be required; however few conflict-torn countries enjoy anything near the depth and breadth of civil institutions or the negotiation and leadership skills available, for example, to South Africa in the 1980s and 1990s.

Post-conflict liberal peace-building is on the global agenda, and will not disappear in the short term given the focus on failed states and security. It must be acknowledged, that, despite flaws, international assistance and interdependence has helped to stem conflict worldwide (Human Security Centre 2010). Much of the literature on conflict resolution and state reconstruction focuses on intrastate conflicts that were supposedly transformed by the skilful interventions of international mediators, NGOs or international organisations. This chapter examines the critical and sometimes contradictory roles that external support/intervention might play in peace-building after conflict.

Outside pressures and oversight may buttress receptivity, hold groups together and provide space for learning to cement. However, the building blocks examined here are a package - the basic ingredients in a slow-cooking recipe - international assistance cannot occur without them. Where the understanding of the necessary conditions is present, however, international assistance may lend a hand in "short-cutting" the historical progression of the conflicting state pacifying. Most importantly, appropriate international assistance must encourage and support the learning process; both directly and by avoiding measures that cause harm. The form is up to the people of the particular state emerging from conflict, and the avoidance of contradictory signals in 
the transformation of the Leviathan is crucial. As such, supporting international organisations should not come with a list of prescriptions that would undo any of this work. Thinking back to the lessons learned on peace-building highlighting in Chapter 2 the local movements enjoy popular support and pursue broad social, political and security agendas if harnessed might be most capable of achieving this combination even if their ideologies are significantly different from those of international actors (Stockholm International Peace Research Institute 2008: 5).

Accepting that an international social compact exists - the "responsibility to protect" if you will - in which sovereignty is a privilege not a right, a framework of neutral international referees based on the newly emerging hybrid (domestic and international) legal framework of third party enforcement could overcome the lack of coherence and legitimacy that characterises current practice. A model of international referees is suggested.

Against this backdrop, Collier's (2007, 2008, 2009) recent proposal for the establishment of partnership domestic and international financial institutions to provide reliable receipt and delivery mechanism to implement government policy (particularly service delivery) is a close practical example. The Regional Assistance Mission in the Solomon Islands (RAMSI) provides a real-world opportunity to reflect on the Collier model. Partnership systems and institutions survived significant political challenge due to a framework of local agreements, regional or international resolutions, treaties, statutes and contracts. Such a framework is necessary to help 'buttress' any international assistance in the event of domestic political or legal contest in paused-conflict states and, at the same time to keep international referees within a social compact with the state emerging from conflict. 


\section{REORIENTATING THE FORMULA-STATE MODEL}

Critics point to the new internationalism that has characterised the post-Cold War period as "the (new) white man's burden". ${ }^{118}$ Rebuilding, or indeed building governance, takes time and as an organised endeavour it may not even be possible. But if there is any hope for more than mere exhaustion in the states that suffer from repeated conflict, then internationals assisting must understand the theory of the previous three chapters. This thesis does not address the actual leadership of the international organisations working on the ground but is much more concerned with deeper understanding and the potential for new policy arising from this. However, it is worth noting that the issue of training and good leadership is likely to be critical. In this respect, pacifying Leviathan in any setting does not just require learning in the leadership and peoples of the state, but also learning of the leadership of any and all supporting international organisations. ${ }^{119}$

The modernisation assumptions of the 1950s and 1960s discussed in Chapter 2 particularly the belief in the natural linear evolution of developing states towards a self-perpetuating market democracy - were found to be flawed (Brugger and Hannan 1983; Roxborough 1988). And yet, the formula-state model too assumes that a market democracy is best and that economic growth in developing countries will culminate in liberal capitalist economies and stable polities resembling Western democracies. The international organisations most strongly committed to market democracy are also those that have played the most significant role in peace-building: for example, the UN, the Organisation of American States (OAS), the OSCE, NATO, the World Bank

\footnotetext{
${ }^{118}$ The White Man's Burden is a poem by English Poet Rudyard Kipling, originally published in the magazine McClures in February 1899 along with the subtitle The United States and the Philippine Islands. It concerns the US's conquest of the Philippines and other former Spanish colonies. The phrase "white man's burden" was latched onto by imperialists in the US as a characterisation for imperialism that justified the policy as a noble enterprise. More recently it is the name of a book by William Easterly, a New York University economics professor and former research economist at the World Bank. He contends that the West has failed, and continues to fail, to enact its ill-formed, utopian aid plans because, like the colonists of old, it assumes it know what is best for everyone. See William Easterly, The White Man's Burden: Why the West's Efforts to Aid the Rest Have Done So Much Ill and So Little Good (New York: The Penguin Press, 2006).

${ }^{119}$ See: Fabrizio Hochschild, 'In and above Conflict: A Study on Leadership in the Untied Nations', (Geneva: Centre for Humanitarian Dialogue, 2010). This recent study lists ten main findings all concerning general qualities of leadership, crucial for the effectiveness of the UN and maximising its resources. Although purporting to address unique challenges to leadership in the UN context (p9), the value in training or insight into the actual problems of post-conflict peace-building is not discussed an interesting omission in an organisation focused in the $21^{\text {st }}$ century on peace-building.
} 
and the IMF. The "solutions" so far employed are based on romantic notions from the 1960s but without the real world conditions of more stable states such as Cambodia.

If the formula-state, as currently conceived, is too optimistic, what then? The evidence presented here paints a vivid picture of pacifying the Leviathan as a lengthy process, often conflict ridden, with no simple answers - certainly not able to be reverseengineered. The solution is also not simply about money and resources necessarily. ${ }^{120}$ The international community has to be realistic about its attempts to assist the short cutting of gradual, incremental change.

\section{i) Slow things down}

Tight and rigid deadlines do not allow sufficient time for new political thinking to emerge or, more importantly, the realignment of groups. In $\mathrm{BiH}$, the emphasis on elections to be held within six to nine months of Dayton caused voters to panic over an uncertain and unarticulated future. They tended to opt for the same nationalist parties that had dominated politics during the war (Caplan 2002: 41). At the other end of the scale, Bougainville's rare status as one of the world's peace success stories has meant that it has a good chance of becoming one of the equally rare success stories of post-conflict governance. This is in great part due to space and time to develop a homegrown variety of "the state". To the outsider, this process may seem painstakingly long but is appropriate for the societal context. At no stage during the New Zealand-hosted peace talks was a timetable dictated (Boege 2006b: 12). As Tapi (2002) observed, the freedom for the various group representatives to adjust to each other was crucial in overcoming the tense atmosphere that naturally prevails when people who have been at war with each other, often for years, commence negotiating. A similarly relaxed timeframe was employed in the demobilisation of arms. The entire Bougainville Peace Agreement envisages $10-15$ years and more of transition.

\footnotetext{
${ }^{120} \mathrm{BiH}$ for example had over $\$ 14$ billion (1996-2007) in aid soon after the war ended. By the end of 1996 alone, 17 different foreign governments, $18 \mathrm{UN}$ agencies and 27 intergovernmental organisations and about 200 NGOs, as well as tens of thousands of troops from 36 countries were involved in the reconstruction effort. This reconstruction per capita (with a population close to that of New Zealand less than four million) makes Germany and Japan look modest. See: Patrice C Mcmahon and Jon Western, 'The Death of Dayton: How to Stop Bosnia from Falling Apart', Foreign Affairs, $88 / 5$ (2009), 69-83.
} 
Most importantly a long-term perspective is accepted by the people. It took four years for elections to commence (June 2005) and since then, state institutions are being built up in earnest. Mortlock, the first New Zealand commander of the Truce Monitoring Group in Bougainville freely admits to being somewhat cynical of military intervention. Intervention should only occur if peace is achievable, by which he means positive receptivity to peace (Mortlock 2001: 69):

The necessary element is that the protagonists want peace. It is not enough to be warweary; they have to be hungry enough for peace to forgive those transgressions that inevitably happen in the course of a peace process.

Winning a peace (as opposed to a war) requires "steely resolve" and endurance not only from the groups involved but also from the international parties. In the most difficult context, it can be years before learning cement into functioning institutions. Internationals can assist this through monitoring (like election monitoring) and support, not simply providing the tools, and expecting the respective states to know how to use them.

\section{ii) Top down approach: contrasting Cambodia and Bougainville}

In 1993, the emerging liberal peace framework seemed to be triumphing and was strongly supported by an international community of peace-builders. Cambodia was hailed as a momentous achievement - the successful replacement of a vicious intrastate and internationalised conflict with an elected government. A new Cambodian constitution and elections provided a new government in line with the promised "comprehensive peace" settlement of the 1991 Paris Agreement, at which point the UN Security Council declared the mission "successfully completed" and promptly withdrew (United Nations Security Council 1993). The UN Transitional Authority in Cambodia (UNTAC) envisioned that it would implement the "peace" through a conservative top-down approach. In other words peace that was "conceived, instituted and imposed" from outside (Richmond and Franks 2007: 32). After this phase, it was optimistically felt that local ownership would be possible relatively quickly (Ibid). 
The opinion of scholars appears to be virtually unanimous that UNTAC, despite the enormity of their mission, achieved organised elections with an unprecedented $90 \%$ participation, helped establish independence, ended the civil war and assisted with the return of refugees (Doyle 1995: 371). As Richmond and Franks (2007: 28) reflected there may be a number of "local political, economic and social dynamics" and " international failings" that modified the liberal peace-building project in Cambodia, but the most important lesson appears to be the uncertainty over whether it is possible to transfer or reverse-engineer the liberal peace. Local elites never altered their winnertakes-all attitude. The conflict continued to be the contention for power and the monopoly on violence and resources, framed now by competition over control of the modern state. If peace-building theory has moved at all, it must be the acceptance that the classic liberal state apparatus cannot simply be auctioned off.

The benefit of an inclusive grassroots approach to paused-conflict governance can be seen in the process which resulted in Bougainville's Lincoln agreement where stakeholders from all levels of the community were involved (Gault 2003). Agreement only made by the top level, when war and conflict are blurred at the edges, would have been inconceivable in a conflict such as this where top down control over these groups is not reality. Instead hundreds of Bougainvilleans attended peace talks and negotiations at Burnham (New Zealand) guaranteeing commitment, stability and implementation of the settlement reached. Local commanders of the BRA and BRF were not the only ones signing the agreement. Members of civil society and traditional institutions (the church and village elders) were present (Carl and Sr. Lorraine Garsu CSN 2002; Tapi 2002). Having civil society assume shared responsibility constituted a "third party" reflecting the feelings of "the people", of exhaustion, or receptivity to alternative strategies and ultimately the desire to play by the new rules. This is in keeping with Lederach's (1997) model for bottom up approaches to peace building, supported by the ever growing literature (Call and Cook 2003; Richmond 2005; van Tongeren et al. 2005).

\section{iii) The real risk of never-ending involvement}

Without the package of building blocks put forward in this research, and true understanding of these dynamics by international actors, international assistance can 
only at best manufacture (negative) peace for as long as there are international parties willing to police and run key elements of the respective states. A current example of international assistance "success" is that of the BiH's multi-ethnic local state institution, the Brčko District (Griffiths 1998).

The Brčko District has been heralded as an international assistance success story due to the mixed Bosniak, Croat and Serb population. It was once the site of a vicious ethnic cleansing campaign, a brutal concentration camp, and a major confrontation line. It was too strategically important to all sides to incorporate within the polarised logic of the Dayton map. Instead its future was left to binding international arbitration, and when no agreement could be reached by the entities, a separate district was created in 1999. The International Crisis Group (2003b) noted:

Once seen as the most likely flashpoint for any renewed warfare in BiH, Brcko has since prospered to such an extent that it is regularly and rightly invoked both as the shining example of international stewardship in $\mathrm{BiH}$ and as a model for emulation by the rest of the country.

By 2009, as Clark (2010: 67-68) recently reported, in stark contrast to other areas such as Stolac, Srebrenica and some parts of Mostar:

Brčko bore few obvious war scars. Damaged and destroyed building were largely repaired or rebuilt; the town had a 'relaxed feel' and there were signs of economic development and rejuvenation.

The resolution to this complex territorial problem has required intense international supervision through the OHR. Reforms were based on a conception of 'democratisation' that prioritised minority rights over majority rule, and its achievements were initially demonstrated in the advanced returnee figures ${ }^{121}$ (Doyle

\footnotetext{
${ }^{121}$ Brčko was taken over by the Serbs during the conflict and completely cleared of Bosniaks and Croats. Two-thirds of its pre-war population were displaced and at the same time some 26,000 Serbs settled there from other areas, taking over empty housing. The Arbitration Tribunal noted in 1998 that Radovan Karadžić and Momčilo Krajišnik (politicians from the Serbian Democratic Party, and in the case Krajišnik, now a war criminal - having been found guilty in 2006 of crimes against humanity while Karadžić is currently facing similar charges) obstructed the return of displaced persons and actively encouraged Serbs to remain in the area to ensure a majority. See: Arbitral Tribunal, 'Arbitral Tribunal for Dispute over Inter-Entity Boundary in Brcko Area, Final Award', (5 March, 1999) at 8. As of the middle of 2009, 22,095 minority returnees (refugees and displaced people) were recorded for Brčko District, the majority of whom returned early on in the District's formation - around 2001-2003. See: United Nations High Commissioner for Refugees Representation in Bosnia and Herzegovina, 'Statistics Package', (UNHCR, 2009). Available here http://www.unhcr.ba/return/pdf\%202009/SP_06_
} 
and Sambanis 2006: 238), which were greatly assisted by the international security presence. A multi-ethnic police force ${ }^{122}$, school system ${ }^{123}$ and independent judiciary ${ }^{124}$ were created. On the surface, an improved economic outlook (in terms of economic opportunities and average salaries) (Bieber 2005: 431), along with the removal of nationalist street names replaced with symbols reflecting unity (road signs in both Cyrillic (Serb) and Latinic (Bosniak and Croat) scripts and new street names for those applied during the Serb occupation of 1992) $)^{125}$ have both assisted. In terms of corruption, which is a real issue in $\mathrm{BiH}$, Brčko was the first place in the country to indict and try politically important people for corruption - including a former judge. Such practices have asserted the "idea" of a coherent local state in Brčko, operating to guarantee rights for all citizens and protecting minority groups (Jeffrey 2006).

At an institutional, top-down level Brčko's achievements are significant. However, its "success" is heavily dependent on the international presence. The international operation in Brčko was at the time the most intensive ever launched in economic, political and financial terms and required the closest supervision in $\mathrm{BiH} .{ }^{126}$ From the outset, the involvement of locals in the reform process was deliberately limited (Jeffrey 2006: 216), and perhaps initially this was sensible. However, accepting the magnitude of what has been achieved in Brčko - particularly in relation to the rest of

\footnotetext{
2009.pdf (last accessed Friday 30 April 2010).

${ }^{122}$ Brčko's multi-ethnic police force is the first for BiH, certified by the UN International Police Task Force as meeting international standards. According to opinion polls, it is well respected by the citizens of Brčko. See: Howard Clarke, 'Brcko District: An Example of Progress in the Basic Reforms in Bosnia and Herzegovina', (Meeting Report 293; Washington: Wilson Centre, 2004).

${ }^{123}$ While protested against initially, particularly by the Serbs, public opinion polls suggest that the introduction of multi-ethnic schooling has had a largely positive impact on popular attitudes. For example, an October 2004 poll indicated that 75 per cent of Bosniaks, 68 per cent of Croats and 62.1 per cent of Serbs agreed with the statement: "It is entirely irrelevant in what language the classes in schools/universities are being held as all these languages are very similar". Across the whole of $\mathrm{BiH}$, the respective percentages were 56.1, 30.3 and 50.7 See: Organization for Security and Cooperation in Europe Mission to Bosnia and Herzegovina, 'Lessons from Education Reform in Brcko', (October: OSCE Mission to BiH Education Department, 2007) at 10.

${ }^{124}$ The independent judiciary (with modern criminal and civil codes) was established by hiring all judges and prosecutors, cementing the rule of law and giving confidence to those who wished to invest in the area that contracts would be enforced. The judiciary has been supported by international training and mentoring.

${ }^{125}$ For example, changing 'Srspskih Oslobodilaca Brčkog' ('the Serb Liberation of Brčko') to 'Bosne Srebrene' ('Silver Bosnia').

${ }^{126}$ NATO troops patrolled the streets and kept the peace. Municipal elections were coordinated by the Organisation for Security and Cooperation in Europe. The EU and the US Agency for International Development provided humanitarian relief and other NGOs helped reduce prostitution and human trafficking in the city.
} 
the country - questions are now being asked about the durability of the tiny state if the international presence leaves.

More importantly it is hard to discern the exact impact of international intervention in the area, especially on everyday inter-ethnic interactions and relations. Few studies have been conducted on the reintegration of ordinary people but like the rest of $\mathrm{BiH}$, as Clark observes there clear signs of a lack of inter-ethnic trust, many missing persons and the continuation of strong and differing interpretations of the past and denial and competing truths (J. N. Clark 2010; Pickering 2007). People do business with each other, but limited engagement with those from other groups means reconciliation is thin at best. In addition, peace is not truly owned. As Pugh and Cobble (2001: 44) warn:

[c]ommunities have a right to own the regeneration of their societies, and without active participation, people will not become "stakeholders" in the peacebuilding ventures ostensibly generated to assist them.

The greatest challenge for the post-conflict society is therefore not the destruction cause to buildings and institutions but rather the challenge of rebuilding the interpersonal relationships (Halpern and Weinstein 2004: 303-04). Within the peacebuilding programme these ordinary people and their problems should not be overlooked. Otherwise, an over-simplistic and overly-optimistic picture while emerge which does not coincide with everyday life. Finding out how such "bridges" between groups are built and encouraging them should be the priority of international assistance. An approach to paused-conflict governance that neglects or pays insufficient attention to the "view from below" 127 is insufficient. This highlights issues not just of quality and ownership but also of sustainability.

\footnotetext{
${ }^{127}$ For the growing body of literature emphasising and exploring the views from below, see as examples: Elizabeth M Cousens and Chetan Kumar (eds), Peacebuilding as Politics: Cultivating Peace in Fragile Societies, Boulder, CO: Lynne Rienner, 2001; Beatrice Pouligny, Peace Operations Seen from Below: UN Missions and Local People, London: Hurst, 2006; Xavier Bougarel, Elissa Helms and Ger Duijzings, 'Introduction', in Xavier Bougarel, Elissa Helms and Ger Duijzings (eds), The New Bosnian Mosaic: Identities, Memories and Moral Claims in a Post-War Society, Aldershot: Ashgate, 2007, Paula M. Pickering, Peacebuilding in the Balkans: The View from the Ground Floor, Ithaca, NY: Cornell University Press, 2007; Beatrice Pouligny, Simon Chesterman and Albrecht Schnabel (eds), After Mass Crime: Rebuilding States and Communities, Tokyo: UN University Press, 2007.
} 


\section{THE INTERNATIONAL SOCIAL COMPACT}

\section{i) "Do no harm."128}

The origins and forces of violent conflict are seldom reducible to internal factors solely. The responsibilities of foreign governments, institutions and individuals have to be kept in mind. State builders are reluctant to assume direct responsibility for the outcomes of their interventions (Chandler 2006). Like domestic actors, the actions of internationals can amount to "spoiling". 129

Somalia is one of the most tragic cases where the international community was partly responsible for the collapse of the state. The legacy of colonialism saw the country divided up and then granted independence in 1960 without the evolution of an experienced political class, like much of Africa. During the Cold War, the US and the Soviet Union competed for influence and control in Somalia because of its strategic location along oil routes from the Persian Gulf. Having assumed the mantle of socialism under General Siad Barre, the Soviet Union was then eager to offer assistance, arming and aiding Somalia in the 1970s. ${ }^{130}$ During attempts to annex Ethiopia's ethnically Somali Ogaden region, the USSR gave their support instead to Ethiopia's new Marxist military government. Somalia lost at huge cost. By the early 1980s, the Soviet Union was replaced by the USA as Somalia's military patron (Bradbury and Healy 2010; Woods 1997). After the civil war in the late 1980s between Somali elites and rival militias, the USA abruptly pulled out leaving a country dependent on imported food but with an abundance of the remnants of the Cold War - arms. Famine loomed and conflict ensued. After media footage of starving children aired in Western states, the UN intervened in April and the US in December 1992. The USA forces soon became actively involved in the civil war. Footage of a dead USA

\footnotetext{
128 "Do no harm" is one of the eight frameworks that UN organisations implementing humanitarian programmes operate under. These frameworks are extrapolated from the three core principles humanity, neutrality, and impartiality

${ }^{129}$ For example, the Australian government's considerable military assistance to the PNGDF provided them with the ability to sustain their war fighting capabilities in Bougainville over such a long time. See: Volker Boege, 'Bougainville and the Discovery of Slowness: An Unhurried Approach to StateBuilding in the Pacific', (Occassional Paper Series, Number 3, June; Brisbane: The Australian Centre for Peace and Conflict Studies 2006b).

${ }^{130}$ From 1969 to 1979 similar transformations occurred throughout Africa including in Angola, Benin, the Republic of Congo, Libya, Madagascar, Mozambique among others.
} 
soldier being dragged through the streets prompted President Bill Clinton to pull troops out in 1994; for the failure which he blamed the UN, quite inaccurately (since the soldier was not under their control). Skipping forward in time, the northern polities of Somaliland and Puntland managed to create their own government structures through grassroots peace-building processes in the early 1990s, the former suffering initial setback through civil war, and the latter becoming the home of pirates, but both developing reasonably democratic political systems (Bradbury and Healy 2010). In the remaining southern area, the coalition known as the Islamic Courts Union (ICU) eventually took control around 2006. Their roots were in Mogadishu's merchant class who wanted a safer environment in which to trade and saw Islam as the common ground through which to unite the country's clans and militias - the local form of the rule of law. For a while they succeeded where the Transitional National Government (TNG - 2000 to 2004) ${ }^{131}$ and the Transitional Federal Government (TFG - 2004 onwards) could not, restoring peace and order and reviving trade and employment (Kirsti Samuels 2007 ). In 2006, the US armed Ethiopian troops and sent them into Somalia to destroy the ICU, driving the moderate leaders into exile and leaving behind the more radical youth splinter group Al-Shabaa (now a designated terrorist group) (Lattimer 2008: 13; Norell 2008). Civil war returned. The northern sector is at peace but under threat. The TFG has no legitimacy or capacity to do anything and cannot hope to govern from the internationally secured area in Mogadishu. The options are to out-pace radicalism or for the international presence to stay long enough to see peace.

The approach of conflict transformation makes a number of salient points for international assistance. It must be centralised around strengthening governance but must also find ways of working within existing traditions and structures of local law to reduce the risk of resentment. Too fervent a promotion of Western ideals if pursued by means of foreign intervention faces a serious challenge in the form of a possible reaction of resentment, leading to a possible backlash against democracy and democratic institutions. International assistance must try to establish peace through supporting the local population in the keeping of that peace, both as actors and

\footnotetext{
${ }^{131}$ Comprised mainly of elites from the diaspora community and former employees of Siyad Barre (the President of the Somali Democratic Republic from 1969 to 1991) it had little credibility inside Somalia, even within Somaliland and Puntland.
} 
beneficiaries, but must resist promoting full scale democracy development until a rule of law is functioning.

\section{ii) Sovereignty is a responsibility}

It is only in the context of doing no harm that any state or the UN can legitimately argue as a global citizen that sovereignty is a responsibility - not a right. Security Council sanction for the use of force can be utilised where threats to neighbours are apparent, but there is no right to impose forcibly democracy, under any circumstances. The concepts underlying this chapter do conflict with the norm of the inviolability of state sovereignty (art 2.7 UN Charter). Arguably over the course of practice in the $20^{\text {th }}$ century and into the $21^{\text {st }}$, a social contract between states and the international community has developed. As referred to in Chapter 2, sovereignty has shifted and a responsibility to protect come to the fore (International Commission on Intervention and State Sovereignty 2001; Thakur 2006). The abortive mercenary hiring of the 1997 Sandline crisis in the PNG/Bougainville conflict, for example, provided the "circuit breaker" (Alley 2003: 252) that allowed for the international intervention. To ignore a country that has no capacity for self-government is now considered morally objectionable, if not illegal (International Commission on Intervention and State Sovereignty 2001). Perhaps a graduated system of sovereignty already exists and ultimately, building a framework for integration into broader regional institutions in recognition of the international social compact may be necessary, but it requires consent.

The pacification of the Leviathan, however, must come from within, as part of learned constitutionalism. This is not to say that any external presence should leave the scene as soon as possible quite the contrary it seems. With true exhaustion and learning from the past, merit may be seen in accepting some form of international "refereeing" or oversight for years to come - but not of course in the mould of the former international trusteeship system (UN Charter, art 77 and 78). Even in transitional administrations, however, the UN is not a trustee ruling on behalf of a sovereign in exile (as in the international law of occupation) or ruling on behalf of the local population, but rather on behalf of the peoples of the world - a global board of referees if you will. 


\section{iii) International referees}

The logic of the learning process is that international help can cut across the historical evolution from conflicting to pacifying, through an agreed and appropriately buttressed framework that holds groups together. International assistance is not defined by the number of agencies on the ground or money spent (although there are obvious incidences where more should have been done by the international community such as in Somalia). In divided societies, if groups wish to participate in governance - a competitive pursuit - then they need an external neutral party to adjudicate.

Sports analogies resonate worldwide. If local groups want to play football competitively, a referee is required to umpire, supply the ball, mark the fields, check the goal posts, etc. The groups agree to follow the rules of the game. Football referees should not have to fight their way to the field, and then confront some teams that brought more than the allowed number of players, some that used guns to scare off the opponents and had supporters who attacked the referee. If the evidence was that there was no basic agreement on the rules and that cheating and fighting would be the result, the game would be postponed until further discussions yielded sufficient agreement. Unlike $\mathrm{BiH}$ where groups were kept apart and rules agreed without consensus, simply getting parties together in the first instance is a crucial first step. New Zealand brought people together during the Burnham talks. For example, once sworn enemies - BRA General Sam Kauona and PNG's Brigadier General Leo Nuia were taken away separately to talk together and "break bread" over dinner in New Zealand.

Back in the world of competitive governance, if people were together long enough, it is possible that they would choose something that was not about favouring just themselves in the immediate term. They would recognise that they needed to be treated fairly when not in power. South Africa was able to negotiate this for themselves by recognising the impossibility of progress if all participants had veto powers, which led to a policy of sufficient consensus moving forward. A top-down social contract needs to be backed by a bottom up recognition of the role that our personal values, social ties, cultural influences and traditions play in setting people against each other as well 
as in healing these relations after conflict. This is analogous to Rawls' (1999: 88) idea of a decent non-aggressive society being that which has:

a common good idea of justice that assigns human rights to all its members; its basic structure includes a decent consultation hierarchy that protects these and other rights and ensures that all groups in society are decently represented by elected bodies in the system of consultation.

The veil of ignorance in Rawls' theory of justice requires that we temporarily ignore our physical, psychological and moral attributes. When this happens, we can decide our future social arrangements without the knowledge of which position we might hold in the future social context. Because of that we are not able to guide our decisions by selfish interests, but only by what we have - a capacity for justice. In doing so, we can consider all possibilities without bias.

For international referees, Sen (2009) has usefully extended Rawls' idea of having the right rules, institutions and social contract in the proposal of setting people free. The job of the international community is not to "resolve" but to provide access to transformation. In other words, they should not attempt to construct their view of a perfectly just society but provide space to allow people in paused-conflict states to live the life of their own choosing. International referees might be able to hold groups together, and help establish and monitor a set of processes that provides for the transformation of the post-conflict society.

In addition, employing a conflict-based lens, as opposed to give simply people a chance for change. However, because governance can also exacerbate the capacity for groups to seek to benefit over others, more time will need to be taken around constitutional processes, interim constitutions and ongoing monitoring of learned constitutionalism, as well as education and training. To this end, key aspects of the decision-making process such as the Auditor General, parts of the judiciary and the police force, the holders of the purse strings, the public prosecutor, members of the electoral commission, among others, may require international actors to assume these roles. This should be co-sharing in governance, not taking over and running the state, and certainly not generating aid dependency. Accusations of neo-colonialism will abound and consent of course is crucial here. The goal is to search for something that 
might work to change things, including strategies to support local reformers overwhelmed by corruption, nepotism, populist (and often racist) slogans and militarism. However, if competitiveness cannot be managed, then it is a race to the bottom, much like an arms race. The framework for support perhaps provides some answers.

\section{INTERNATIONAL ASSISTANCE FRAMEWORKS}

Rubin (2006) argues that rivalries and fragmented authority at the international level mirror the division in post-conflict states like Afghanistan. He calls for a unified international decision-making body to coordinate the various agendas. Indeed, alternatives could be constructed in the legal compacts and agreements with the country concerned to provide a coherent strategy. Dann and Al-Ali's (2006) study of Iraq, Sudan and East Timor's constitution-making processes under external influence raises the point of how international influence should be governed by international law. The sort of legal regime governing external influence has been set by UN Security Council Resolutions, or in the case of occupations, the law of belligerent occupation can assist. Whether influence is exercised in conformity with those rules is another matter. These laws did not, for example, stop the USA from interfering in the constitution-making process in Iraq after handing over sovereignty to the interim government. General rules of public international law could apply, however, and the authors argue that certain substantive standards of the political process, such as the right to democratic governance and certain human rights, have emerged as being inalienable and external actors have to respect these standards.

Bell (2008) shows how peace agreements and constitutional arrangements have hybrid characteristics. The law's role has been reconceived in the peace agreement context so as to address the particular challenges of transiting from the idea of agreements as contracts or treaties as social contracts. A nice example concerns arrangements to enforce aspects of peace agreements. Typically, domestic obligations have to be enforced in domestic courts. But the complexity of peace arrangements often produces innovative ways of enforcement, such as Security Council approved arbitration, or provisions for guarantors of the agreement, or indeed a series of relationships (Ibid, 
184). Since various forms of agreement are now at the centre of peace processes, it is necessary to reconceptualise the categories of domestic and international law to accommodate arrangements that draw on both. This is the new law of third party enforcement (negotiated settlement) which is quasi-codified and supports the notion of an international social compact.

Moving forward, clearly articulated frameworks are required, for consent, for legitimacy, for coherence, and indeed for assistance, which can survive a challenge by local politicians (or other spoilers). ${ }^{132}$ Two examples are addressed - Collier's Independent Service Authority (ISA) model and RAMSI.

\section{i) Supporting governance through the ISA model}

In addressing international assistance, Collier argues (2007, 2008, 2009), that workable ways to bridge state collapse may exist for states of the "bottom billion" (countries where people live in abject poverty) to escape from a number of "development traps". One key element of his proposals that is along the lines of the international referees proposed here is the establishment of partnership domestic and international financial institutions to provide reliable receipt and delivery mechanisms to implement government policy, chiefly in the delivery of essential services (2008). A board would be brought together, the ISA, made up of aid donors, expatriates and members of the government, sharing responsibility for effectively administering public funds from donor governments (and any other potential source included in the national budget - such as substantial national resource revenue). ${ }^{133}$ These funds

\footnotetext{
132 This part of the thesis draws directly on Andrew Ladley and Jessie Williams, 'Chapter 9 the Collier Challenge: How Can Reliable Transitional Financing Systems Be Created in 'Barely Functional' States?', in Manas Chatterji (ed.), Economics of War and Peace: Economic, Legal, and Political Perspectives (Contributions to Conflict Management, Peace Economics and Development, (14: Emerald Group Publishing Limited, 2010), 147-65

133 A centralised source of easy and unaccountable cash tends to annihilate a fledgling democracy by creating patronage machines and lowering the pressure to develop a social contract that comes with effective taxation. In resource rich countries, strong checks and balances are more important to escape the resource curse (i.e. Nauru). Taiwan (Republic of China) is a significant donor in Solomon Islands for example, "providing SBD 85 million, (approximately AUD 17.2 million), including over 6 per cent of the development budget, in 2008. Some commentators have suggested that Taiwan's aid is neither transparent nor accounted for, and in some cases directly [channeled] to members of parliament through, for example, the Rural Constituency Development Fund." The requirement to account quarterly for this was waived by ministerial directive in 2008 although normal audit accountability requirements remain. Carole Pretorius, Peter Lokay, and Haggai Arumae, 'Solomon Islands: Public Financial Management - Performance Report', (Rotterdam: ECORYS Nederland BV, 2008). There is no doubt that Taiwanese government funding has contribution to corruption in the Solomon Islands. In
} 
would then be channelled to private service providers and NGOs by entering into contracts with them; and monitor the performance of providers generating competition and at the same time protect service delivery from the patrimony and corruption that is common within the targeted states (Collier 2008: 14).

Without the ISA model, international actors may choose to withhold funding. However, because domestic services are least capable of managing funds effectively and delivering services, much less with probity, bypassing the core functions of the state (centralising funds for public expenditure) is precisely the purpose. In addition, as the OECD's Fragile States Group (2008) recognises, contracted-out services or functions should enable the state to strengthen its capacity and legitimacy over time. In terms of buttressing receptivity to peace, in particular, effective delivery and improvements would greatly assist. It is possible that governments may choose to channel more of their own revenue devoted to social spending through the ISA rather than through spending ministries whose role would then become focused on policy design, and taking away any avenue to corruption.

Recognising and managing risk are key features of Collier's model. It is possible, he argues, to reduce post-conflict governance risks by a combination of mutuallyreinforcing steps aimed at economic recovery, external guarantees of peacekeeping, fairer elections, and internationally supported public service delivery — all sustained at least over a 10-year-period. In this context, the international community is required to pay for the transition of the 'bottom billion' and the process must be sustained by restructured incentives that hold the players to a non-violent shared governance.

In addition, foreign donors fearing committing resources in these precarious states, have sometimes adopted a "wait and see" attitude to assistance. The risk here is obvious. Such a stance can cause the chauvinists to 'win', as the current situation in

2001 for example, the \$US25 million "loaned" to the SIG in compensation to victims of the conflict was clouded in controversy. Its rapid and chaotic distribution led to claims of unfairness and extortion and accusations that particular ministers had improperly benefit. In 2006 general election, Taiwan was accused of financially supporting candidates. Graeme Dobell, 'China and Taiwan in the South Pacific: Diplomatic Chess Versus Pacific Political Rugby', (Sydney: Lowy Institute for International Policy Policy Brief, 2007) at 11. In the same year the Taiwanese ambassador announced the Rural Community Development Funds $(\$ 400,000)$ to be paid annually to every MP to spend as they wished in their constituencies. 
Zimbabwe illustrates where urgent calls for international support for the reform process to match populous expectation have been made, crucially to make it more difficult for the extremists to grab power once more. As Morgan Tsvangirai recently said, "Don't make us pay for working with Mugabe" (Masamvu and Steinberg 2009).

\section{ii) Buttressing against chauvinism in post-conflict states}

Stable states have good legal systems, where wealth formation is encouraged, and tax systems provoke the population into demanding accountability - what is called shareholder democracy. They are therefore able to withstand surprise events (both internal and external) and contestation continues to remain within the boundaries of existing institutional arrangements. In states emerging from conflict, and weak states generally, as has been illustrated throughout this thesis, democracy can be simply the staging of elections and groupism is often fostered. Even in a country like Fiji, this is evident, where a Westminster parliamentary system is unable to overcome communal representation which has seriously inhibited shared common political space. Politics has been pushed to the fringes, and the two most chauvinist positions are constantly being elected in a "winner takes all" contest. There is an incentive to get elected without shareholder democracy because there is generally no real form of taxation and no social contract in terms of the accepted rules and checks and balances to hold government accountable - let alone afford them the legitimacy to capture the middle ground, thus discouraging traditional spoilers (rebellions, coups etc).

Collier emphasises that one can, indeed one must keep outside international assistance working through a range of strategies, including controlling finance and giving security guarantees. Whilst international referees cannot substitute indefinitely for the sort of social contract that must ultimately underpin government-by-consent, the goal is to buy sufficient time to get most of the warlords off the game and then to change the incentive structure. In the immediate aftermath of violent conflict, before the articulation of new rules of governance, a major goal is to get people busy, reestablishing infrastructure, state and economic institutions, state services like schools, getting work for demobilised soldiers, rebuilding homes, getting markets functioning, etc. In this respect, Collier's model provides for accountable spending where it could add the most value. 
Collier's model, however, does not project out beyond the first year or two. He does not explain the mechanisms that would implement and support ISAs, much less their ability to adapt. Leaders will eventually tire of shared arrangements. Shared sovereignty arrangements need to be supported with as much buttressing as possible. This may include international resolutions and treaties, domestic legislation, constitutional amendments, arrangements for international personnel who will work in the foreign state (including dealing with the issue of immunity), some means of connecting directly with the people, a means of dispute resolution, and so on. Where Collier stresses speed, it is argued here that durability requires the greater emphasis on the framework right from the start. The following components are needed:

- Consent: There is no guarantee that international charters alone, either those of the UN or private sector led ones administered by international organisations, such as De Beer's Kimberly Process or the Extractive Industries Initiative, will be enough to buttress shared international sovereignty in paused-conflict states. Returning to the idea of international social compacts, in order to capitalise on receptivity and learning, and in being weary of groupism, they would need to be signed and adhered to by all relevant parties within a state. It may be difficult, for example, in places like Somalia, to find people to give consent but for there to be any chance of short-cutting the alternative, incentives must be clearly presented to the people as well as to the previously warring factions. Spoilers too must be accounted for, as must constitutional questions and the issues of immunity as part of the international side's responsibility to do no harm.

- Legitimacy ties in with consent and with the function of the mission. Without legitimacy, consent may very well be withdrawn or popular support wane. The need for the institution or position holder (i.e.,. the Auditor General) to be seen as fair and efficient, not simply another arm of the "winner takes all" style of government, means that it/they will have to appeal to the public mood. Public support will also protect it from changing, political contexts that would otherwise destroy it. Therefore, such institutions will take on a very different feel from Collier's separate administrative function, also concerned with public affairs and countering misinformation. While local ownership and rule 
setting are paramount, the notion that policy and politics can be left intact, separate from the administration (or "refereeing) is dubious. What is the purpose of a monitoring function, if not to ensure the rules are followed, based on what "works"? Invariably in the roles that internationals may fill, judgements will have to be made, not simply the carrying out of policy.

- Immunity: The accountability of international referees to the local population raises issues of immunity from prosecution. Traditionally governments have provided to other sovereign states and their representatives certain rights and facilities not available to ordinary citizens such as privileges and immunities. While these are extended in accordance with international law and are customarily based upon reciprocity and diplomatic practice developed through years of inter-governmental relationship, international intervention has moved on from traditional, military led operations. Yet individuals are accorded immunity in their role as state diplomats, officials of international organisations, and military and even civilian personnel under international agreements or individual contracts. Immunity and its potential to allow impunity are dangerous for any mission on the ground trying to generate or retain the confidence of the local population, not to mention establish the rule of law domestically. Not only that, it goes against the UN's aim to rebuild peace and security if the rebuilders are immune from their criminal actions (Ladley 2005). The dimension of accountability is so far missing from this discussion, and must be not just on political terms but also on legal terms. Accountability to the local population, and the principle of doing no harm is just as important as accountability to donors and contributing countries. Legal immunity from the laws of a host country has a solid rationale in international law; however the military has its own processes for dealing with crimes where immunity exists and is also subject to the UN codes. For civilians and the police, there are no equivalent processes and the current UN sanctions are essentially employment related. Making provision for civilians who commit crimes on peace operations was the objective of the Status of Force Agreement for RAMSI in the Solomon Islands, which ceded its criminal jurisdiction only if the sending country could prosecute any offences in its domestic courts. New 
Zealand and Australia amended their legislation to cover non-military staff. ${ }^{134}$ Arguably each place that provided an international referee would have to do this. Other options include: on-mission prosecution with a court established on the ground with the host state's consent; and the establishment of an independent body akin to an Ombudsman's office which could look at broader complaints relating to the operation of policy or to individuals where the complainant was not satisfied with the outcome of the internal investigatory process. However, like a Board of Inquiry, the Ombudsman lacks enforcement power as its findings are only recommendations

- Guarantees: Collier suggests that military interventions in small, lessdeveloped countries where legitimate governments had been overthrown in a post-Iraq, post-colonial world, is controversial, requiring greater clarity of method and purpose. Collier does not elaborate as to when exactly intervention is warranted and how it should be carried out. History has taught us that confused recipes for intervention are particularly dangerous. In keeping with the theme of buttressing, it would seem highly appropriate to emphasise other guarantees. Oversight mechanisms building upon the election monitoring model, for example, could be employed during the transitional period (10 - 15 years at least) to strengthen the implementation of constitutions. Security should be maintained and strengthened (i.e.,. cleaning up the police force if necessary) on the ground, not from afar with the only resource being the use of large scale force.

Most importantly international assistance must improve governance and assist with pacifying the Leviathan. The RAMSI intervention in the Solomon Islands (2003 - ) provides a governance model analogous to Collier's, emphasising the importance of compacts or codes and charters to form shared sovereignty arrangements between the international community and a government to reduce conflict. The challenges, however, discussed in this research, of spoilers, of war by other means, of groupism, have not been adequately considered by Collier to date. These issues are interconnected and complicated, not least due to the fact that any one of the possible

134 Crimes (Overseas) Amendment Act 2003 (Australia) and the Crimes and Misconduct (Overseas Operations) Act 2004 (New Zealand). 
ways international referees can assist goes to the heart of any state, but none more so than controlling revenue flows. While aid becomes a contractual arrangement, (and the money will be well spent in the short term) the governance challenge is to convert this idea into something that does not get out-chauvanised in post-conflict situations. Collier's ideas are focused on the first year to two and are transitional, not transformative. Establishing a properly buttressed framework can assist in building immunity in local populations so that all sorts of international referees can assist in pacifying the Leviathan.

\section{iii) Comparing THE ISA Model with the Regional Assistance Mission in Solomon Islands (RAMSI)}

The experience of the RAMSI is the closest real-world comparator to Colliers's thesis - albeit in very different and arguably quite favourable circumstances - and is useful in illustrating some of the inherent difficulties to resolve for international assistance. The widespread social unrest that broke out in 1999 between the indigenous people of Guadalcanal and settlers from adjacent Malaita island developed into a low level armed conflict between opposing ethnic militias and continued after the signing of the Townsville Peace Agreement in 2000 with the complete breakdown of law and order. What Chabal and Daloz (1999) refer to as the "instrumentalisation of disorder" whereby criminality becomes a key political instrument, resulting in the effective capture and pillaging of the state by a small gang of corrupt leaders, ex-militants and renegade police officers. This left the government in a situation where they could not meet debt obligations or supply basic services. In addition, the Provincial Government Act assigned the responsibility for various service provision to the provincial governments (health, education, agricultural extension, etc.), which they were unable to supply for the most part (Frankel 2004).

An independent authority - the Solomon Islands Rehabilitation Authority (SIRA) was initially proposed to take over the government in the areas of law and order and financial management (Wainwright 2003). The government would have continued to run the remaining policy areas, but with substantial input from SIRA (Fullilove 2006). This plan, however, was regarded by Australia as too intrusive of sovereignty and the approach eventually adopted and deployed in July 2003 was a unique kind of 
authority. RAMSI is not a transitional administration but a technical assistance package or framework for strengthened assistance. The official aim outlined in the framework document states that "strengthened assistance will address the most serious specific threats to security and economic recovery in Solomon Islands" (Solomon Islands Government 2003).

The package came with security. RAMSI was designed as a police-led operation backed by (the unused threat of) military force. Officers of RAMSI's participating police force were not advisors, but investigators with full domestic police power under Solomon Islands law. The results were dramatic. Law and order were quickly restored. In addition to re-establishing law and order, work under RAMSI's economic governance pillar focused on the ongoing provision of advisors and in-line personnel to work with the government, mainly through the Ministry of Finance and Treasury, to stabilise government finances. The short-term objectives of controlling expenditure and work towards budget stabilisation were met very quickly (AusAID 2004).

The Special Coordinator's Office in Honiara (headed by an Australian diplomat) and a high-level inter-departmental committee in Canberra is responsible for overall coordination (Dinnen and Stewart 2008). The speedy manner in which RAMSI restored peace (law and order), essential services and stabilised government finances prompted considerable praise (Fullilove 2006). These achievements are an anomaly among the generally disappointing results of international interventions. RAMSI was commended as "a model for future deployment" (Watson 2005: 37). More recent initiatives include:

- developing the capacity of staff and systems in the Ministry of Finance and Treasury;

- implementing anticorruption measures which have reduced leakages particularly in Treasury and Inland Revenue;

- implementing accountability processes in Customs;

- providing foreign direct investment legislation and management; and

- transparency of tax and duty exemptions.

The backlog of central government financial statements were eliminated, and debt interest and trade creditor arrears were paid off (AusAID 2008; George 2008; Pacific 
Islands Forum of Eminent Persons Group 2005; Winter et al. 2008). Australia has committed finances and resources to RAMSI until the end of 2013 (Osifelo 2009a). The World Bank and Asian Development Banks are currently supporting the budget showing their trust in the accountability structures (Osifelo 2009b). ${ }^{135}$

In addition to law and order and budget stabilisation, RAMSI's Participating Policy Force:

- cleaned up the Royal Solomon Islands Police (RSIP) - around 25\% (or 400 officers) were removed, and approximately the same percentage of that cohort again were charged with a variety of offence including corruption and murder;

- disbanded the paramilitary division which played a significant part in the conflict in 2000, and established joint patrols and community policing with the RSIP;

- provided guarding and security services;

- pursued criminal investigations; and

- trained new recruits.

The RAMSI police force is now less involved in day-to-day activities but focused on recruiting, training and mentoring RSIP, including promoting women's participation and targeting corruption, while at the same time supporting traditional justice. Not only was law and order restored relatively quickly in the Solomon Islands, but the ongoing sense of security has, for the most part, endured because of the long haul approach to peace. And because security does not just mean military might, in this regard, international assistance could come in other forms. RAMSI funds prosecutors, lawyers, judges, magistrates and court administration and logistics personnel, not just the police. In addition, support has been provided by the justice and prison systems,

\footnotetext{
${ }^{135}$ Criticisms have however still been aired - similarly to those leveled against other interventions - but calling for adaptation of the mission rather than its total withdrawal. There are a number of inherent weaknesses and reforms are ongoing to address issues of accountability and transparency, including concerns over the spending of special funds like the Tsunami Disaster Relief Fund. Pretorius, Lokay, and Arumae, 'Solomon Islands: Public Financial Management - Performance Report'. A number of other initiatives remain outside of this process, including regional and bi-lateral programmes. Others are concerned that RAMSI advisers are perceived by local bureaucrats to be contractors who are essentially working for private-sector interests, rather than for the public service and that Australian has used the programme to promote overseas business interests and private sector growth. Tim O'connor, Sharni Chan, and Dr James Goodman, 'Australian Aid: Promoting Insecurity', The Reality of Aid 2006: Focus on Conflict, Security and Development (London: Zed Books, 2006), 172-89, Tim Anderson, 'The Limits of Ramsi', (Sydney: AID/WATCH, 2008).
} 
and a number of legal experts have performed roles such as the Solicitor General and the Public Solicitor. RAMSI has also worked to improve accountability and transparency in government and strengthen institutions such as the Ombudsman and the Auditor General.

For the purposes of evaluating the merit of this international referees type of international assistance, RAMSI established something analogous to the proposal by Collier. International staff initially ran the budget process, accountability improved, donors approved, funds flowed (both from local revenue sources and donors), and a functioning state was quickly re-established. The example thus suggests that an ISAlike arrangements worked essentially as Collier hoped. But the buttressing supports need to be appreciated, without which RAMSI would have been kicked out of the country some time ago.

\section{iv) Building immunity against regression and support for RAMSI}

A comprehensive legal framework carefully underpins RAMSI. It was implemented only after formal requests from the Solomon Islands' Prime Minister and Governor General as well as the unanimous passage of enabling legislations through Parliament. Regional in nature, under the auspices of the Pacific Islands Forum, RAMSI developed from the framework of the Forum's Biketawa Declaration of 2000 which sets out principles of good governance, democracy, the rule of law and human rights. The heads of government and foreign ministers endorsed the declaration's security recognition that: "the need, in time of crisis or in response to members' request for assistance, for action to be taken on the basis of all members of the Forum being part of the extended Pacific Islands family" (section 3).

RAMSI's mandate was also explicitly agreed between the SIG and the countries of the Pacific through the Pacific Islands Forum at the time of the mission's deployment in 2003. Endorsement of the mission also came from the UN Security Council and the UN Secretary General (although not by formal resolution). In addition, RAMSI was underpinned by a specific international treaty between the SIG and Australia, New Zealand, Fiji, Papua New Guinea, Samoa, and Tonga establishing the mission's 
deployment and reflecting the agreed upon mandate. ${ }^{136}$ Further, a legal foundation was established in the domestic law of the Solomon Islands, in the form of the Facilitation of International Assistance Act 2003 passed unanimously by Parliament in July 2003. The Act incorporates the RAMSI treaty, thus giving direct legal domestic effect to it. The Act provides powers, privileges and immunities of the type already agreed to by the SIG in the RAMSI Treaty.

It was only after all this architecture was in place that assistance was requested under section 3 formally, through notice given by the Governor General to the regional governments, to establish RAMSI and intervene in Solomon Islands.

In directly appealing to the population RAMSI also established a Performance Framework in 2005 which enables ongoing evaluation of this architecture, assessing its work against publicly stated objectives. The evaluation process includes:

- a People's Survey untaken by an independent contractor with Solomon Islands' survey staff to obtain information on the views of locals on issues of relevance;

- a performance report prepared by an independent group of experts;

- $\quad$ self assessment mechanisms; and

- oversight by the SIG/RAMSI Performance Assessment Working Group.

In 2006, the context rapidly changed. Summarising these events is useful because they illustrate what is inevitable, that international referees and shared sovereignty arrangements will challenge and be challenged by local incumbents. The most dramatic evidence of trouble was in the major riots and arson in the capital Honiara that followed the April 2006 general election and the apparent victory of one faction led by Snyder Rini in securing office. In the wake of the riots and a vote of no confidence in the elected leader, Prime Minister Manasseh Sogavare took office and

\footnotetext{
${ }^{136}$ Agreement between Solomon Islands, Australia New Zealand, Fiji, Papua New Guinea, Samoa and Tonga concerning the operations and status of the police and armed forces and other personnel deployed to Solomon Islands to assist the restoration of law and order and security. The mandate's aim was to address challenges including civil unrest and lawlessness, economic decline and stagnation, and a dramatic decline in government standards. It covered: restoration of civil order; stabilisation of government finances; promotion of longer term economic recovery and revival of business confidence; and the rebuilding of government institutions or machinery.
} 
promptly attempted to set up a commission of inquiry into the riots' cause. This went against RAMSI legal advice that an inquiry would prejudice immediate criminal legal action against two MPs facing charges for inciting the riots. Both MPs were strong supporters of the Prime Minister and hence essential for him to retain office (AusAID 2008). There was also concern that the RAMSI police had failed to anticipate or control the riots (Moore 2006). In September 2006, the SIG declared the Australian High Commissioner persona non grata, claiming he was interfering in domestic politics (Sogavare 2006). A further concern was the SIG decision to appoint Julian Moti as the Attorney General. In that position, Moti would have been responsible for the proposed inquiry. He was at the time wanted under Australian anti-paedophile legislation. The relationship between the SIG and RAMSI was also strained further by the SIG attempt to rearm its local police, prompting the Australian Foreign Minister to publish an open letter in a Solomon Islands newspaper defending RAMSI's achievements and warning of a "deliberate push to undermine" it. Prime Minister Sogovare replied, accusing Australian of trying to run a "parallel government" (Jones 2007). However, the people had learned from conflict and were strongly against rearming the police since it was looted police weaponry that had plunged the country into crisis before 2003 .

From 2006, therefore, growing threats were made by the SIG to repeal the 2003 founding legislation, thus revoking consent and forcing the removal of RAMSI. These threats failed. Indeed, they backfired. A majority of MPs were needed to revoke the legislation but instead Prime Minister Sogovare's government was toppled from office in a parliamentary vote of no confidence. RAMSI also faced a constitutional legal challenge in the Solomon Islands' courts which was unsuccessful. ${ }^{137}$ The change in administration $^{138}$ was in significant part due to its attempts to govern without the restrictions resulting from RAMSI's role in the administration, a framework that was buttressed by the comprehensive agreement by a predecessor parliament, by the region and, arguably, by the population itself. When the political context changed these original arrangements held, not least because the general public saw RAMSI's

\footnotetext{
${ }^{137}$ Nori v Attorney-General [2006] HCSI-CC 172

138 Noting of course that this happened in a parliamentary system, which allowed a change of government by a confidence vote in Parliament. Other such confidence mechanism could be employed in other electoral systems.
} 
presence as crucial for security. The 2008 and 2009 People's Surveys confirms this, with 86 percent and 88 percent of respondents interviewed supporting its continued presence in the country (ANU Enterprise 2008, 2009).

The Solomon Islands is a compelling case for the kind of framework required for international referees to assist with paused-conflict governance. Traditionally, constitutions have left measures against, for example, official corruption to legislation, because of the nature of democratic spoilers, in particular, in getting consent for partnership institutions during transitional periods will add to the buttressing and, in theory, will place them beyond the reach of politicians in power. There are a number of mechanisms that can be employed here, as was the case in the post-apartheid South African constitution where transitional arrangements to manage funds carefully were itemised. $^{139}$

\section{v) Co-sharing not generating dependency}

Where interveners stay too long, they can be accused of creating "aid trauma". The latest criticisms of RAMSI illustrate this point. There is no doubt that the SIG, in the capital Honiara at least, was unable to manage the conflict that had emerged by 2003 - the response led by Australia was a robust military-style intervention by the region, nominally a police mission, but strongly militaristic from the start. The goal was to remove the weapons, secure law and order, and then rebuild the institutions of government, strongly supported by actual personnel doing the work. The situation now is less clear. The serious criticism suggests that the core mission was achieved relatively early, but that seven years down the track, the longer-term ones are failing. This is ostensibly because the local population appears to be increasingly resentful of intervention (possibly a complete take-over) in governance, whilst it remains grateful for the security stability (T. Anderson 2008). The arguments developed in this thesis would suggest, that like Collier's work, the insights of the lens of conflict transformation have not yet been taken on board. There is a deepening resentment at relative deprivation and weakening domestic engagement. The analysis of this case

139 See Section 240 - Transitional arrangements: State Revenue Fund 
suggests that there are no simple prescriptions. Better insights to understand why things have gone wrong after such apparently ideal conditions are needed.

As Wainwright (2006) has noted, among others, securing security so rapidly in the Solomon Islands has left locals with high expectations of what RAMSI can do. Compounding the problem is a widespread perception that it is only RAMSI that can make things work. The phrase, Weitim olketa RAMSI bae kam stretem ("Wait for RAMSI to come and fix it") has become a common utterance. Local ownership is a key variable in post-conflict peace-building. Among the number of criticisms of RAMSI has been the need to turn to a strategy focused on indirect approaches rather than doing or directing (Baser 2007). For RAMSI's activities to be sustainable it must now create genuine space for local initiative and accountability. This was the conclusion reached by the Pacific Islands Forum of Eminent Persons Group (2005). In 2013, RAMSI will have been in the Solomon Islands for over ten years, reflecting initial estimates (Moore 2006). However the notion that it can simply withdraw is an impossibility (Lineham 2006). This comes back to the importance of learned constitutionalism, that without the articulation of a future international assistance will in most instances not mesh with what local people want. The Solomon Islands tried to hold such discussions on new governance arrangements, with a draft constitutions circulating since 2004, none of which have yet been brought before Parliament.

\section{v. CONCLUSION}

Where international assistance is used in paused-conflict governance, it must encourage and support learning both directly and by avoiding measures that would harm or contradict. In a busy area of international relations, aid, governance and (mostly) domestic conflict, despite the prevalence of the formula-state, inevitably this field of post-conflict peace-building is developing quickly. The UN and other's approaches are constantly changing, reacting, backtracking, searching for new "lessons learned". International actors can support societies in re-building governance into stable states that can practice positive peace, but must be mindful of the futility in a top down approaches and in reverse-engineering the liberal peace. The importance 
of understanding the preceding triad of theoretical building blocks is crucial; otherwise unplanned never-ending involvement could be the outcome.

The role of internationals is to provide outside pressure and oversight buttressing receptivity, holding groups together and providing space for learning to cement. They may be able to short-cut the historical progression of the conflicting state becoming the pacifying state. While not perfect, Collier's challenge is to think differently and practically about solving problems. It is not about fixing or resolving, but implementing workable structures in some areas so that people in paused-conflict states can negotiate governance arrangements of their own choosing, not simply react to fear for their future. A clear shared sovereignty framework with consent for international referees will assist in this regard, as part of the international social contract. Conflict transformation warrants internationals with coherent strategies and well-structured frameworks (that will actually assist with local learning), who accept long term support roles in slow paced democratisation. Implementing these agreements with states may take time, but does not presuppose no security provision. RAMSI's buttressing was done in a remarkably short time, but it was well-signposted, the region was prepared and ready, virtually every single individual in the Solomon Islands parliament was receptive and hence willing to legislate, and the people were determined that the past should remain just that. Elsewhere, the conditions might not be so favourable but, if receptivity is not there, offering something not fully thought through will not assist in changing relationships but will once again result in a "winner takes all" response and ultimately fail. The process of agreeing on the kind of international assistance proposed here is therefore part of the learning, and can contribute to pacifying Leviathan. 


\section{8: Conclusion}

From the outset, this thesis has accepted that there would be several steps in pacifying Leviathan. The first - the bulk of this thesis - has been to establish concepts and perspectives that might explain the complexities. Subsequent steps, including thinking through issues of implementation, will be necessary but are beyond the scope of this thesis. As argued throughout, pacifying Leviathan is hard conceptually and practically. In developed states, it took centuries and major conflicts, including two World Wars. In current examples, such as Sudan, Iraq, Congo, Zimbabwe, Somalia, Bougainville in Papua New Guinea and Mindanao in the Philippines, the processes have already been in a timescale of years, even decades. In each of those examples by the end of 2010 the situation had apparently paused in relatively low-key conflicts rather than full-scale civil wars. This thesis has explored factors that are relevant to transforming "the pause" into positive peace. As discussed, however, for many domestic actors the goals might be different, especially if they are still fighting in the mind. In Zimbabwe, for example, the goal of one side appears to be to prolong the pause long enough to launch another campaign of violence; the mirror goal of the other side appears to be to prolong the pause long enough to make a return to violence either impossible or ineffective. The first would obviously constitute a failure of the peace process (but a victory for the strategists of violence). Equally obviously, the second would represent a dramatic success for the peace process and possibly a significant exercise in learning as set out in Figure 2 in Chapter 1 of this thesis.

Because of the immense importance of actual strategies, the lack of clear steps at this point of the argument might be frustrating. But those in the field have faced the same issues. A major, UK think-tank on development issues, for example, recently explored the practical implications of the UK government's announcement that $50 \%$ of its new aid funding would go to "fragile states" (Overseas Development Institute 2009: 1)

In ...conflict-related settings, the international community faces the dual task of promoting peace while helping to build more effective, inclusive and responsive states. This has led to a growing realisation among donors (including, for example, the UK Department for International Development DFID, the Development Assistance Committee (DAC) of the OECD, the UN and the World Bank) that their peace-building 
and peace-building interventions should be brought closer together - 'peace-building for peace' as the UNDP has put it.

Even here, however, there are few practicalities on the table, with the paper showing the challenges rather than setting out strategies. Hence, the paper (ibid, p. 4) concludes that donors need to:

- start with the domestic context,

- be more humble in their approach to fragile states,

- be careful not to create undue expectations about what the state can deliver and

- sharpen their political understanding and support for peace-building.

These arguably are further reflections of the difficulties, rather than practical steps for implementation. In concluding the arguments of this thesis, therefore, only one implication, informed by the perspectives of learning outlined in Figure 2 of Chapter 1, will be outlined: the transformation process needs to take longer, for the right reasons.

For domestic and international actors, a strategy that from the outset envisaged taking longer (rather than scrambling to exit) would have major implications for the theory and practice of peace missions. Obviously, a strategy on this basis would need agreement from all key actors - and funding. But the justification for taking longer would include strategies for building the learning processes that are central to pacifying Leviathan. There would be limits of course. There is an obvious difference between a peace operation becoming part of a frozen conflict (as in Cyprus) and being framed from the outset as intended to pacify Leviathan. The key would be to create the right incentives for the parties to understand groupism, weigh the relativities of continued conflict against alternatives, be receptive and learn - rather than seeing an extended international operation as an acceptable, long-term "solution".

There are plenty of examples supporting taking longer to improve the odds of pacifying Leviathan. As discussed in the previous chapter, the Regional Assistance Mission in Solomon Islands (RAMSI) has been in operation for seven years, with no 
fixed date for its withdrawal. In neighbouring Bougainville, the drawn out stages of the post 1997 have apparently provided time for "peace by peaceful means" to take hold in the imagination of the people as well as almost all the key leaders. Further, deferring key decisions on independence for 15 years produced an ideal climate for slow cooking on all the key ingredients. South Africa was not of course an international mission as such. Still, the parties took four years from Nelson Mandela's release in 1990, to implement decisions resulting in the elections and interim constitution. And it was several more years before the constitution was finalised. Meanwhile, the South African Truth and Reconciliation Commission process produced several years of ongoing public learning, with the explicit rejection of the core philosophies and methodologies of the apartheid-era government. And across that whole period, visioning scenarios created learning for key leaders, the enormous significance of which is only just beginning to be made public (Global Business Network 2009).

Understanding groupism suggests that more time would be useful for any projects that might build identities to reduce the risks of mono-identities, whilst also recognising the inherent value of belonging to a community or group - South Africa's rainbow nation for example or the less well-known Bougainville process of rebuilding relationships between previous communities and protagonists.

Getting agreement for slower cooking, however, requires careful discussion at all levels. There is no easy mechanism to combat sovereignty demands and local nationalism, if leaders/voters seek advantage in early or cheated elections, followed by demands for the withdrawal of international missions - sometimes with the external support that promises personal or group advantage, sometimes in the face of international pressures. Clearly, there is work to be done to create the necessary, institutional frameworks for post-conflict peace-building operations. But even without a fully-developed framework, the advantages of taking longer should allow all the key building blocks discussed in this thesis to be better explored: groupism, receptivity, learning and international support.

Planning on longer transformation periods would also allow for a host of other strategies that would build on the arguments of this thesis, such as connecting public 
discussions of the suffering from the conflicts (Truth Commissions, etc) with changed rules of governance (new constitutions, etc); or establishing responsibility for and technical mechanisms to combat cheating elections, alongside ways of addressing the issues (international observers/support, independent agencies) or the complexities of disarming both the weapons and the minds of combatants.

None of this suggests that there may not be times to "strike while the iron is hot". But, in general, it would be a brave commentator who suggested that "quick fixes" such as the Dayton Peace Accord for BiH in 1994, were "best practice" for future conflicttransformation.

The practical results might, at least in the short term, not be as radical as the criticisms might imply. But across time, there will be more learning and more strategies, linked by a better understanding of the issues involved. Such developments may then pacify Leviathan in current conflicts via strategies that learn from, but short-cut, the centuries that established democracies apparently required. 


\section{References}

Ackerman, Bruce (1991), We the People: Foundations (Cambridge Harvard University Press).

--- (1997), 'The Rise of World Constitutionalism ', Virginia Law Review, 83 (4), 771 97.

Ackerman, Peter and DuVall, Jack (2000), A Force More Powerful: A Century of NonViolent Conflict (P; New York: Palgrave).

Adams, Willi Paul (2001), The First American Constitutions: Republican Ideology and the Making of the State Constitutions in the Revolutionary Era (Lanham, Maryland: Rowman and Littlefield Publishers Inc).

Ajello, Aldo (2008), 'The Role of Elections in Stabilizing Post-Conflict Countries', in Tobias von Gienanth (ed.), Elections in Post-Conflict Countries - Lessons Learned from Liberia, Sierra Leone, DR Congo, and Kosovo (Accra, Ghana: Center for International Peace Operations and the Kofi Annan International Peacekeeping Training Centre), 28-33.

Akashi, Yasushi (1993), 'The Challenge of Peacekeeping in Cambodia: Lessons to Be Learned', Presented to the School of International and Public Affairs (Columbia University: November 29).

Alley, Roderic (2003), 'Ethnosecession in Papua New Guinea: The Bougainville Case', in Rajat Ganguly and Ian Macduff (eds.), Ethnic conflict and secessionism in South and Southeast Asia: causes, dynamics and solutions (New Delhi: Sage Publications ), 225-56.

Anderson, Benedict (1991), Imagined Communities: Reflections on Origin and Spread of Nationalism (London: Verso).

Anderson, Tim (2008), 'The Limits of Ramsi', (Sydney: AID/WATCH).

Andreas, Peter (2004), 'The Clandestine Political Economy of War and Peace in Bosnia', International Studies Quarterly, 48 (1), 29-51.

Andrew, Justice Warrick (1997), 'Report of the Commission of Inquiry into the Engagement of Sandline International', (Boroko: Supreme Court of Papua New Guinea).

Anghie, Antony (2001), 'Colonialism and the Birth of International Institutions: Sovereignty, Economy, and the Mandate System of the League of Nations; ' NYU Journal of International Law and Politics 34, 513-633.

Annan, Kofi (1999), 'Two Concepts of Sovereignty', The Economist 352, 49-50.

--- (2005), 'In Larger Freedom: Towards Development, Security and Human Rights For All', Report fo the Secretary-General (A/59/2005; New York: United Nations General Assembly).

ANU Enterprise (2008), 'People's Survey 2008', (Honiara: RAMSI).

--- (2009), 'People's Survey 2009', (Honiara: RAMSI).

Aolain, Fionnuala Ni (1998), 'The Fractured Soul of the Dayton Peace Agreement: A Legal Analysis', Michigan Journal of International Law, 19 (4), 957-1004.

Arbitral Tribunal (1999), 'Arbitral Tribunal for Dispute over Inter-Entity Boundary in Brcko Area, Final Award', (5 March).

Ardrey, Robert (1961), African Genesis: A Personal Investigation into the Animal Origins and Nature of Man (New York; Macmillan Publishing Co). 
Arendt, Hannah (1961), 'Preface: The Gap Between Past and Future ', Between Past and Future: Six Exercises in Political Thought (London: Faber), 3-15.

--- (1964), Eichman in Jerusalem: A report on the banality of evil (New York: Viking).

Ascher, William (1999), Why Governments Waste Natural Resources: Policy Failures in Developing Countries (Baltimore: Johns Hopkins University Press).

Attar, Mohsen Al and Miller, Rosalie (2010), 'Towards an Emancipatory International Law: The Bolivarian reconstruction', Third World Quarterly, 31 (3), 347-63.

AusAID (2004), 'Solomon Islands: Rebuilding an Island Economy', (Canberra: Commonwealth of Australia).

--- (2008), 'Annual program performance report for Solomon Islands 2007-08', (Canberra: Commonwealth of Australia).

Austin, Beatrix, Fischer, Martina, and Giessmann, Hans (eds.) (2011), Advancing Conflict Transformation. The Berghof Handbook II (USA: Barbara Budrich Publishers).

Ayoob, Mohammed (1995), The Third World Security Predicament: State Making, Regional Conflict and the International System (Boulder: Lynne Rienner).

Azar, Edward (1990), 'The Analysis and Management of Protracted Conflict', in Vamik D Volkan, Josept V Montville, and Demetrios A Julius (eds.), The Psychodynamics of International Relationships, Volume II: Unofficial Diplomacy at Work (Lexington: Lexington Books).

Azar, Edward and Burton, John (1986), International Conflict Resolution: Theory and Practice (Brighton: Wheatsheaf).

Ballentine, Karen and Nitzschke, Heiko (eds.) (2005), Profiting from Peace: Managing the Resource Dimensions of Civil War (Boulder, Colorado: Lynne Rienner).

Bancroft, Ian (2010), "European standards' hinder Balkans', The Guardian (online).

Banks, Michael (1987), 'Four Conceptions of Peace', in Denis J. D. Sandole and Ingrid Sandole-Staroste (eds.), Conflict Management and Problem Solving: Interpersonal to International Applications (F.Pinter; London), 259-74.

Bannon, Alicia (2007), 'Designing a Constitution-Drafting Process: Lessons from Kenya', Yale Law Journal, 116 (8), 1824-72.

Barnett, Michael (2006), 'Building Republican Peace: Stablizing States after War', International Security, 30 (4), 87-112.

Barnett, Michael and Zurcher, Christoph (2009), 'The Peacebuilder's Contract: How External Statebuilding Reinforces Weak Statehood', in Roland Paris and Timothey Sisk (eds.), The Dilemmas of Statebuilding: Confronting the Contradictions of Postwar Peace Operations (New York: Routledge), 23-52.

Barnett, Michael, et al. (2007), 'Peacebuilding: What Is in a Name?', Global Governance, 13, 35-58.

Baser, Heather (2007), 'Provision of Technical Assistance Personnel in the Solomon Islands: What can we learn from the RAMSI experience?', (Maastricht: European Centre for Development Policy Management).

Bauman, Zygmunt (1989), Modernity and the Holocaust (Cambridge: Polity Press).

BBC (2010), "No excuse for violence': Statement by NI ministers', BBC News, 13 July.

Beate, Jahn (2007), 'The Tragedy of Liberal Diplomacy: Democratization, Intervention and Statebuilding', Journal of Intervention and Statebuilding, 1 (2), 211-29.

Beck, Ulrich (2006), The Cosmopolitan Vision (Cambridge: Polity Press ).

Bedjaoui, Mohamed (1979), Towards a New International Economic Order (New York Holmes \& Meier). 
Begic, Prof. Dr. Kasim (2000), 'Address Before the Presidents of European Constitutional Courts at the Preparatory Meeting', (Brussels: Oct. 20-21).

Bell, Christine (2008), On the Law of Peace: Peace Agreement and the Lex Pacificatoria (New York: Oxford University Press).

Bellamy, Alex (2008), 'The "Next Stage" in Peace Operations Theory', in Alex Bellamy and Paul Williams (eds.), Peace Operations and Global Order (London: Routledge), 17-38.

Bellamy, Alex and Williams, Paul (2010), Understanding Peacekeeping (2 edn.; Cambridge: Polity Press).

Bellamy, Alex and Williams, Paul (2004a), 'Conclusion: What Future for Peace Operations? Brahimi and Beyond', International Peacekeeping, 11 (1), 183212.

--- (2004b), 'Introduction: Thinking Anew about Peace Operations', International Peacekeeping, 11 (1), 1-5.

Benner, Thorsten, Binder, Andrea, and Rotmann, Philipp (2007), 'Learning to Build Peace? United Nations Peacebuilding and Organization Leaning: Developing a Research Framework', GPPi Research Paper Series No. 7 (Berlin: Global Public Policy Institute).

Benner, Thorsten, Mergenthaler, Stephen, and Rotmann, Philipp (2011), The New World of UN Peace Operations. Learning to Build Peace? (Oxford: Oxford University Press).

Benomar, Jamal (2004), 'Constitution-Making after Conflict: Lessons for Iraq', Journal of Democracy, 15 (2), 81-95.

Bensahel, Nora (2007), 'Organising for Nation Building', Survival, 49 (2), 43-76.

Bercovitch, Jacob (1984), Social Conflicts and Third Parties: Strategies of Conflict Resolution (Boulder, Colorado: Westview).

Berdal, Mats (2009), Building Peace After War (London: International Institute for Strategic Studies).

Berghof Foundation, (1999-2014), 'Conflict Transformation - Our Interpretation '.

Bieber, Florian (2005), 'Local Institutional Engineering: A Tale of Two Cities, Mostrar and Brcko', International Peacekeeping, 12 (3), 420-33.

Bigelow, Robert (1969), The Dawn Warriors: Man's Evolution Toward Peace (Boston: Little Brown).

Bloomfield, David and Reilly, Benjamin (1998), 'The Changing Nature of Conflict and Conflict Management', in Peter Harris and Ben Reilly (eds.), Democracy and Deep-rooted conflict (Stockholm: Institute for Democracy and Electoral Assistance (IDEA)).

Boege, Volker (2006a), 'Traditional Approaches to Conflict Transformation Potentials and Limits', Berghof Handbook for Conflict Transformation (Berlin: Berghof Research Centre for Constructive Conflict Management ).

--- (2006b), 'Bougainville and the Discovery of Slowness: an Unhurried Approach to State-Building in the Pacific', (Occassional Paper Series, Number 3, June; Brisbane: The Australian Centre for Peace and Conflict Studies ).

Boege, Volker, et al. (2008), 'On Hybrid Political Orders and Emerging States: State Formation in the Context of 'Fragility', (Berlin: Berghof Research Center for Constructive Conflict Management).

Boege, Volker, et al. (2009), 'Building peace and political community in hybrid political orders', International Peacekeeping, 16 (5), 599-615. 
Bostock, William Walter (2010), 'The Psychological Preconditions for Collective Violence: Several Case Studies', Journal of Alternative Perspectives in Social Sciences, 2 (1), 273-97.

Botes, Johannes (2003), 'Conflict Transformation: A Debate Over Semantics or a Crucial Shift in the Theory and Practice of Peace and Conflict Studies', The International Journal of Peace Studies, 8 (2), 1-27.

Boulding, Elise (1990), Building a Global Civic Culture: Education for an Interdependent World (New York: Syracuse University Press).

Boulding, Kenneth (1950), A Reconstruction of Economics (New York and London: Wiley, and Chapman and Hall).

--- (1978), Stable Peace (Austin, Texas: University of Texas Press).

Boutros-Ghali, Boutros (1992), 'An Agenda for Peace: Preventative Diplomacy, Peacemaking and Peace-Keeping. ', (A Report of the Secretary-General on the Work of the Organization; New York: United Nations ).

--- (1995a), 'An Agenda for Development', (New York: UN Department of Information).

--- (1995b), 'Supplement to the Agenda for Peace', (Report of the Secretary-General on the Work of the Organization; New York: United Nations ).

Bowles, Samuel and Gintis, Herbert (2003), 'The Origins of Human Cooperation', in Peter Hammerstein (ed.), The Genetic and Cultural Evolution of Cooperation (Cambridge: MIT Press), 429-44.

Bradbury, Mark and Healy, Sally (2010), 'Whose peace is it anyway? Connecting Somalia and international peacemaking', (Accord Issue 21; London: Conciliation Resources).

Brahimi, Lakhdar (2007), 'Statebuilding in Crisis and Post-Conflict Countries ', Building Trust in Government - 7th Global Forum on Reinventing Government (Vienna, Austria).

Brahm, Eric (2009), 'Judging Truth: The Contributions of Truth Commissions in PostConflict Environments', in Noha Shawki and Michaelene Cox (eds.), Negotiating Sovereignty and Human Rights: Actors and Issues in Contemporary Human Rights Politics (Burlington: Ashgate Publishing Company ), 119-40.

Brain, Charles Kimberlin (1981), The Hunters or the Hunted? :An Introduction to African Cave Taphonomy (Chicago and London: The University of Chicago Press).

Braithwaite, John, et al. (2010) Reconciliation and Architectures of Commitment: Sequencing Peace in Bougainville [online text], ANU Press

Brass, Paul (1995), Ethnicity and Nationalism: Theory and Comparison (Newbury Park, CA: Sage Publications).

--- (1997), Theft of an Idol: Text and Context in the Representation of Collective Violence (Princeton: Princeton University Press).

Bratt, Duane (1997), 'Explaining Peacekeeping Performance: The UN in Internal Conflicts', International Peacekeeping, 4 (3), 45-70.

Brown, Archie (1999), 'Russia and Democratization', Problems of Post Communism, $46(5), 5-6$.

Brown, Nathan J (2005), 'The Final Draft of the Iraqi Constitution: Analysis and Commentary', (Washington: Carnegie Endowment for International Peace ).

Browning, Christopher (1998), Ordinary Men: Reserve Battalion 101 and the Final Solution in Poland (2 edn.; New York: Harper Collins). 
Brugger, Bill and Hannan, Kate (1983), Modernization and revolution (London: Routledge).

Buckley-Zistel, Susanne (2006), 'Remember to Forget: Chosen Amnesia as a Strategy for Local Coexistence in Post-Genocide Rwanda', The Journal of the International African Institute, 76 (2), 131-50.

--- (2008), 'We Are Pretending Peace: Local Memory and the Absence of Social Transformation and Reconciliation in Rwanda', in Phil Clark and Zachary D. Kaufman (eds.), After Genocide: Transitional Justice, Post-conflict Reconstruction and Reconciliation in Rwanda and Beyond (London: Hurst).

Burton, John (1987), Resolving Deep-rooted Conflict: A Handbook (Lanham: University Press of America).

--- (1990), Conflict Resolution and Provention (New York: St Martins Press).

Bush, George (2002), 'The National Security Strategy of the United States of America', (Washington, DC: White House).

Bush, George H W (1990), 'Toward a New World Order - Speech by the President of the U.S.A. given to a joint session of the United State Congress', (Washington DC: 11 September).

Bush, Ken (1996), 'Beyong Bungee Cord Humanitarianism: Towards a Developmental Agenda for Peacebuilding', Candian Journal of Development Studies, Special Issue 75-92.

Bush, Robert and Folger, Joseph (1994), The Promise of Mediation (San Francisco: Jossey-Bass Publishers).

Butler, Michael J. (2012), 'Ten Years After: (Re) Assessing Neo-Trusteeship and UN State-building in Timor-Leste', International Studies Perspectives, 13 (1), 85104.

Cahen, Michel (2005), 'Success in Mozambique', in Simon Chesterman, Michael Ignatieff, and Ramest Thakur (eds.), Making States Work: State Failure and the Crisis of Governance (Tokyo United Nations University), 213-33.

Call, Charles (2004), 'Is Transitional Justice Really Just?', Brown Journal of World Affairs, 11 (1), 101-13.

--- (2005), 'Institutionalising Peace: A Review of Post-Conflict Peacebuilding Concepts and Issues for DPA', (New York: United Nations Department of Political Affairs).

Call, Charles and Cook, Susan (2003), 'On Democratization and Peacebuilding', Global Governance, 9 (2), 233-46.

Call, Charles and Cousens, Elizabeth (2008), 'Ending Wars and Building Peace: International Responses to War-Torn Societies', International Studies Perspectives, 9, 1-21.

Campbell, Stephen (2011), 'Consturing Top-down as Bottom-up: The Governmental Co-option of Peacebuilding "From Below"', vis-à-vis: Explorations in Anthropology, 11 (1), 39-56.

Campbell, Susanna (2008), 'When Process Matters: The Potential Implications of Organisational Learning for Peacebuilding Success', Journal of Peacebuilding \& Development, 4 (2), 20-32.

Campbell, Susanna, Chandler, David, and Sabaratnam, Meera (2011), A liberal peace? The problems and practices of peacebuilding (London: Zed Books).

Caplan, Richard (2002), A New Trusteeship? International Administration of War Torn Territories (Oxford: Oxford University Press). 
Carl, Andy and Sr. Lorraine Garsu CSN (eds.) (2002), Weaving consensus: the Papua New Guinea - Bougainville peace process, ed. Celia McKeon (ACCORD, 12; London: Conciliation Resources).

Carlsson, Ingvar, Sung-Joo, Han, and Kupolati, Rufus M (1999), 'Report of the Independent Inquiry into the Actions of the United Nations during the 1994 Genocide in Rwanda', S/1999/1257 (United Nations: 16 December 1999).

Carothers, Thomas (1999), 'The Rise of Democracy Assistance', in Thomas Carothers (ed.), Aiding Democracy Abroad: The Learning Curve (Washington Carnegie Endowment for International Peace), 19-46.

--- (2002), 'The End of the Transition Paradigm', Journal of Democracy, 13 (1), 5-21.

--- (2004), 'Critical Mission: Essay on Democracy Promotion', (Washington, DC: Carnegie Endowment for International Peace).

Cartmill, Matt (1996), A View to a Death in the Morning: Hunting and Nature Through History (Cambridge, Massachusetts: Harvard University Press).

Cashman, G (1993), What Causes War? (Lexington: Lexington Books.).

Chabal, Patrcik and Daloz, Jean-Pascal (1999), Africa Works: disorder as political instrument (Oxford and Bloomington Indiana: James Currey and Indiana University Press).

Chan, Stephen (2010), The end of certainty: towards a new internationalism (London: : Zed Books).

Chandler, David (1998), The History of Cambodia (3 edn.; London: Westview).

--- (2000), Bosnia: Faking Democracy after Dayton (2 edn.; London and Sterling, VA: Pluto Press).

--- (2004), 'The Responsibility to protect? Imposing the "liberal peace"', International Peacekeeping, 11 (1), 59-81.

--- (2006), Empire in Denial: The Politics of State Building (London: Pluto Press).

--- (2010), 'The Uncritical Critique of 'Liberal Peace", Review of International Studies, $1-19$.

--- (2011), "The Uncritical Critque of the 'Liberal Peace", in S.P Campbell and D Chandler (eds.), The Liberal Peace? The Problems and Practices of Peacebuilding (174-190; London: Zed Books).

Chemerinsky, Erwin (1992), 'Supreme Court and the Fourteenth Amendment: The Unfulfilled Promise', The Symposium: One Hundred Twenty-Five Years of the Reconstruction Amendments: Recognizing the Twenty-Fifth Anniversary of the Loyola of Los Angeles Law Review 25 (4), 1143-58.

Chesterman, Simon (2002), 'East Timor in transition: self-determination, statebuilding and the United Nations', International Peacekeeping, 9, 45-76.

--- (2004a), You, the People: The United Nations, Transitional Administration, and State Building (Oxford: Oxford University).

--- (2004b), You, the People - The United Nations, Transitional Administration, and State Building. (1 edn.; Oxford: Oxford University Press) 296.

--- (2007), 'Ownership in Theory and in Practice: Transfer of Authority in UN Statebuilding Operations', Journal of Intervention and Statebuilding, 1 (1), 326.

Chesterman, Simon, Ignatieff, Michael, and Thakur, Ramesh Chandra (2005), Making States Work: State failure and the crisis of governance. (New York: United Nations University Press).

Chopra, Jarat (ed.), (1998), The Politics of Peace Maintenence.

Chopra, Tanja (2010), 'Dispensing Elusive Justice: The Kenyan Judiciary Amongst Pastoralist Societies', Hague Journal on the Rule of Law, 2, 95-110. 
Clark, Howard (2000), 'Civil Resistance in Kosovo', (London Pluto).

Clark, Ian (2005), Legitimacy in International Society (Oxford: Oxford University Press).

Clark, Janine Natalya (2010), 'Bosnia's Success Story? Brcko District and the 'View from Below' ', International Peacekeeping, 17 (1), 67-79.

Clarke, Howard (2004), 'Brcko District: An Example of Progress in the Basic Reforms in Bosnia and Herzegovina', (Meeting Report 293; Washington: Wilson Centre).

Clausewitz, Carl von (1993), On War (Vom Kriege), eds Michael Howard, Beatrice Heuser, and Peter Paret (1832 original edn., Oxford World Classic; London Oxford University Press).

Coakly, John (2008), 'Has the Northern Ireland Problem Been Solved', Journal of Democracy, 18 (3), 98-112.

Cohen, Richard (2002), By the sword: a history of gladiators, musketeers, samurai, swashbucklers, and Olympic champions (New York: Modern Library).

Cohen, Roger (1998), Hearts Grown Brutal: Sagas of Sarajevo (New York: Norton).

Colletta, Nat and Cullen, Michelle 'Violent Conflict and Transformation of Social Capital: Lessons from Cambodia, Rwanda, Guatemala and Somalia', (Washington, DC: World Bank).

Collier, Paul (2000), 'Economic Causes of Civil Conflict and Their Implications for Policy', (Washington DC: World Bank).

--- (2007), The Bottom Billion: Why the Poorest Countries Are Failing and What Can Be Done About It (Oxford: Oxford University Press).

--- (2008), 'Haiti: From Natural Catastrophe to Economic Security. A Report for the Secretary-General of the United Nations', (Oxford: Oxford University Press).

--- (2009), War, Guns and Votes: Democracy in Dangerous Place (New York: Harper Collins).

Collier, Paul, et al. (2003), Breaking the Conflict Trap: Civil War and Development Policy (Oxford: Oxford University Press and World Bank).

Committee on Armed Services (2008), 'Inquiry into the Treatment of Detainees in U.S. Custody', (110th Congress, 2nd Session: United States Senate).

Connolly, Danielle (2011), 'The Global Political Agreement and Democractic Transition in Zimbawe', Oxford Transitional Justice Research Working Paper Series (Oxford: University of Oxford Centre for Socio-Legal Studies), 1-7.

Cooper, Neil (2007), 'On the Crisis of the Liberal Peace', Conflict, Security and Development, 7 (4), 605-16.

Cousens, E M and Kumar, C (eds.) (2001), Peacebuilding as Politics: Cultivating Peace in Fragile Societies (Boulder, CO: Lynne Rienner).

Cramer, Christopher (2006), Why Civil War is Not a Stupid Thing: Accounting for Violence in Developing Countries (London: Hurst \& Co).

Craven, Gregory (2004), Conversations with the constitution: not just a piece of paper (Sydney University of New South Wales Press).

Crocker, Chester and Hampson, Fen Osler (1996), 'Making Peace Settlements Work', Foreign Policy, 104, 54-71.

Crocker, Chester, Hampson, Fen Osler, and Aall, Pamela (eds.) (2001), Turbulent Peace: The Challengse of Managing International Conflict (Washington: United States Institute of Peace Press).

--- (eds.) (2007), Leashing the Dogs of War: Conflict Management in a Divided World (Washington United States Institute of Peace Press).

Curle, Adam (1971), Making Peace (London: Tavistock). 
--- (1990), Tools for Transformation (United Kingdom: Hawthorn Press).

--- (1996), Another Way: Positive Responses to Violence (Oxford: John Carpenter ).

Curry, James, Riley, Richard, and Battistani, Richard (eds.) (1999), Constitutional Government: the American Experience (4 edn., Iowa: Kendall/Hunt Publishing Company).

Curtis, Devon (2012), 'The Contested Politics of Peacebuilding in Africa', in Devon Curtin and Gwinyayi Dzinesa (eds.), Peacebuilding, Power and Politics in Africa (Ohio University Press), 1-30.

Cutillo, Alberto (2007), 'Reviewing Fifteen Years of Peacebuilding. Past, Present and Future of International Assistance to Countries Emerging from Conflicts and Italy's Contribution', (Working Paper 01/2007; Italy: School for International Studies at the University of Trento).

Dahl, Robert A (1971), Polyarchy: Participation and Opposition (New Haven: Yale University Press).

Dahrendorf, Nicola (2003), 'A Review of Peace Operations: A Case for Change. Synthesis Report', (London: Conflict, Security and Development Group, King's College London).

Danilovic, Vesna and Clare, Joe (2007), 'The Kantian Liberal Peace Revisted', American Journal of Political Science, 51 (2), 397-414.

Dann, Philipp and Al Ali, Zaid (2006), 'The Internationalized Pouvoir Constituant Constitution-Making Under External Influence in Iraq, Sudan and East Timor ', Max Planck Yearbook of United Nations Law, 10, 423-63.

Danner, Mark (2009), Stripping Bare the Body: Politics, Violence and War (New York: Nation Books).

--- (2010), 'To Heal Haiti, Look to History, Not Nature', The New York Times, 22 January 2010, p. A31.

Darby, Phillip (2004), 'Pursuing the Political: A Postcolonial Rethinking of Relations International', Millennium - Journal of International Studies, 33 (1), 1-32.

--- (2009), 'Rolling Back the Frontiers of Empire: Practising the Postcolonial', International Peacekeeping, 16 (5), 699-716.

Dart, Raymond (1953), 'The predatory transition from ape to man', International Anthropological and Linguistic Review, 1, 207-08.

Date-Bah, Eugenia (2003), Jobs After War: A Critical Challenge in the Peace and Reconstruction Puzzle (Geneva: International Labour Organization).

Dawkins, Richard (1976), The Selfish Gene (New York: Oxford University Press).

De Coning, Cedric Hattingh (2012), 'Complexity, Peacebuilding and Coherence: Implications of Complexity for the Peacebuilding Coherence Dilemma', (Stellenbosch University).

de Waal, Frans (1989), Peacemaking Among Primates (Harvard University Press).

Democratic Unionist Party (2003), 'DUP Assembly Election Manifesto', (Belfast: DUP).

Denitch, Bette (2000), 'Unmaking multi-ethnicity in Yugoslavia: Media and metamorphosis observed', in Joel Halpern and David Kideckel (eds.), Neighbors at War. Anthropological Perspectives on Yugoslav Ethnicity, Culture and History. (Pennsylvania: Pennsylvania State University).

Development Assistance Committee (1997), 'DAC Guidelines on Conflict, Peace and Development Co-operation. ', (Paris: DAC, OCED).

--- (2003), 'A Development Co-operation Lens on Terrorism Prevention: Key Entry Point for Action', (Paris: DAC, OECD). 
DFID (2006), 'Eliminating World Poverty: Making Governance Work for the Poor', White paper on International Development presented to Parliament (London: UK Parliament).

Diamond, Larry (1995), 'Promoting Democracy in the 1990s: Actors and Instruments, Issues and Imperatives', (New York: Report to the Carnegie Commission on Preventing Deadly Violence).

Diamond, Larry, Linz, Juan J, and Lipset, Seymour Martin (1995a), 'Introduction: What Makes for Democracy?', Politics in Developing Countries: Comparing Experiences with Democracy (Boulder, Colorado: Lynne Rienner), 1-66.

Diamond, Larry, Linz, J, and Lipset, S M (1995b), Democracy in Developing Countries: Comparing Experiences with Democracy (Boulder, Colorado: Lynne Rienner).

Dickinson, Laura (2003), 'The Promise of Hybrid Courts', The American Journal of International Law, 97 (2), 295-310.

Dingley, James and Kirk-Smith, Michael (2000), 'How Could They Do it? The Bombing of Omagh, 1998', Journal of Conflict Studies, (Spring), 105-26.

Dinnen, Sinclair and Stewart, Firth (2008), 'Politics and Statebuilding in the Solomon Islands'.

Djilas, Milovan (1977), Wartime, trans. Michael B Petrovich (New York and London: Harcourt Brace Jovanovich).

Dobbins, James (2003), America's role in nation building: from Germany to Iraq (Santa Monica: RAND Corporation).

Dobbins, James, et al. (2005), The UN's Role in Nation Building: From the Congo to Iraq (Santa Monica: RAND Corporation).

Dobell, Graeme (2007), 'China and Taiwan in the South Pacific: Diplomatic Chess Versus Pacific Political Rugby', (Sydney: Lowy Institute for International Policy Policy Brief).

Donahue, Patrick (2010), 'Bosnia Serb Leader Won't Rule Out Republika Srpska Independence', Bloomberg, Sunday April 25.

Donais, Timothy (2009), 'Empowerment or Imposition? Dilemmas of Local Ownership in Post-Conflict Peacebuilidng Processes', Peace and Change, 34 (1), 3-26.

--- (2012), Peacebuilding and local ownership: post-conflict consensus-building (New York: Routledge).

Dorney, Sean (1998), The Sandline Affair (Sydney: ABC Enterprises).

Douglas, William (1962), 'Lawyers of the Peace Corps', American Bar Association Journal, 48, 909-10.

Doyle, Michael W (1983), 'Kant, Liberal Legacies and Foreign Affairs: Parts 1 and 2', Philosophy and Public Affairs, 12 (3-4), 205-54 and 323-53.

--- (1986), 'Liberalism and World Politics ', American Political Science Review, 80 (4), 1151-69.

--- (1995), UN Peacekeeping in Cambodia: UNTAC's civil mandate (London: Lynne Rienner).

--- (1997), 'Ways of War and Peace: Realism, Liberalism and Socialism', (New York: W. W. Norton and Company).

--- (1999), 'A Liberal View: Preserving and Expanding the Liberal Pacific Union', in T.V.Paul and John A. Hall (eds.), International Order and the Future of World Politics (Oxford Oxford University Press), 41-66.

Doyle, Michael W and Sambanis, Nicholas (2006), Making War and Building Peace: United Nations Peace Operations (New Jersey: Princeton University Press). 
Druckman, Daniel (1994), 'Nationalism, Patriotism and Group Loyalty: A Social Psychological Perspective', Mershon International Studies Review, 38 (1), 4368.

Duffield, Mark (2001), Global Governance and the New Wars (London Zed Books).

--- (2007), Development, Security and Unending War: Governing the World of Peoples (Cambridge: Polity Press).

Dunant, Henry (1986), A Memory of Solferino (International Committee of the Red Cross).

Durkheim, Emile (1893), The Division of Labour in Society (New York: Free Press).

Dyer, Gwynne (1985), War: The Lethal Custom (London: Guild Publishing).

Ehrenreich, Barbara (1997), Blood Rites: Origins and History of the Passions of War (New York: Metropolitan Books.).

Eibl-Eibesfeldt, Irenaus (1979), The Biology of Peace and War: Men, Animals and Aggression (London: Thames \& Hudson).

Eide, Espen B, et al. (2005), 'Report on Integrated Missions. Independent Study for the Expanded UN ECHA Core Group', (Oslo, London: Norwegian Institute of International Affairs and King's College).

Eisner, Manuel (2003), 'Long-term Historical Trends in Violent Crime', Crime and Justice: A Review of Research, 30, 83-142.

--- (2008), 'Modernity Strikes Back? A Historical Perspective on the Latest Increase in Interpersonal Violence (1960-1990)', International Journal of Conflict and Violence, 2 (2), 288 - 316.

Elias, Norbert (1971), 'The Genesis of Sport as a Sociological Problem', in Eric Dunning (ed.), The Sociology of Sport: A Selection of Readings (London Frank Cass), 88-115.

--- (1994), The Civilising Process, trans. Edmund Jephcott and Stephen Mennell (Oxford: Blackwell Publishing Ltd).

Elliott, Marianne (2000), The Catholics of Ulster: A History (New York: Guilford).

Ellis, Andrew (2006), 'Elections are Not an Island: The Process of Negotiating and Designing Post-Conflict Electoral Institutions', Post-Conflict Elections in West Africa: Challenges for Democracy and Reconstruction (Accra, Ghana: International IDEA).

Ellis, Elisabeth (2005), Kant's Politics: Provisional Theory for an Uncertain World (New Haven: Yale University Pres).

Elster, Jon (1995), 'Forces and Mechanisms in the Constitution-Making Process', Duke Law Journal, 45, 364-96.

Ember, Carol (1978), 'Myths About Hunter-Gatherers', Ethnology, 17 (4), 439-48.

Eppler, Erhard and Munkler, Herfried (2004), 'New Wars" Discourse in Germany', Journal of Peace Research, 41 (1), 107-17.

Erikson, Mikael and Wallensteen, Peter (2004), 'Armed Conflict. 1989 - 2003', Journal of Peace Research, 41 (5), 625-36.

Escobar, Arturo (1995), Encountering Development: The Making and Unmaking of the Third World (Princeton, NJ: Princeton University Press).

Etzioni, Amitai (2007), Security First: For A Muscular, Moral Foreign Policy (New Haven and London: Yale University Press).

Evera, Stephen van (1994), 'Hypotheses on Nationalism and War', International Security, 18 (4), 5-39.

Farrand, Max (ed.), (1966), The Records of the Federal Convention of 1787 (New Haven: Yale University Press). 
Fay, Marie-Therese, Morrissey, Mike, and Smyth, Marie (1999), Northern Ireland's troubles: The human costs (London Pluto).

Feldman, Noah (2005), 'Imposed Constitutionalism', Connecticut Law Review, 97 (4), 857-90.

Fetherston, Ann Betts (2000), 'Peacekeeping, Conflict Resolution and Peacebuilding: A Reconsideration of Theoretical Frameworks', International Peacekeeping, 7 (1), 190-218.

Finkelman, Paul (1981), An Imperfect Union: Slavery, Federalism, and Comity (Chapel Hill: University of North Carolina Press).

--- (2000), 'Garrison's Constitution: The Covenant with Death and How It Was Made', Prologue: Quarterly of the National Archives and Records Administration, 32, 230-45.

Fischer, Martina and Ropers, Norbert (2004), 'Introduction ', in Alex Austin, Martina Fischer, and Norbert Ropers (eds.), Transforming Ethnopolitical Conflict. The Berghof Handbook (Wiesbaden: VS Verlag für Sozialwissenschaften), 11-22.

Fisher, Markus (2000), 'The Liberal Peace: Ethical, Historical, and Philosophical Aspects', BCSIA discussion Paper 2000-07 (Harvard University: Kennedy School of Goverment).

Fisher, Simon and Zimina, Lada (2009), 'Just Wasting Our Time? Provocative Thoughts for Peacebuilders', in Beatrix Schmelzle and Martina Fischer (ed.), Peacebuilding at a Crossroads? Dilemmas and Paths for Another Generation. Berghof Handbook Dialogue No 7 (Berlin: Berghof Foundation), 11-35s.

Flower, Harriet (2004), The Cambridge Companion to the Roman Republic (Cambridge: Cambridge University Press).

Fombad, Charles M (2007), 'Challenges to Constitutionalism and Constitutional Rights in Africa and the Enabling Role of Political Parties: Lessons and Perspectives from Southern Africa.', American Journal of Comparative Law, $55,1-46$.

Forges, Alison Des (1999), 'Leave None to Tell the Story: Genocide in Rwanda', (Human Rights Watch).

Francis, Diana (1994), 'Power and conflict resolution ', in International Alert (ed.), Conflict Resolution Training in the North Caucasus, Georgia and the South of Russia (London: International Alert).

Frank, Andre Gubder (1966), The Development of Underdevelopment (New England Free Press).

Frankel, Jon (2004), The Manipulation of Custom: from uprising to intervention in the Solomon Islands (Sydney: Pandanus Books).

Freud, Sigmund (1933), 'Why war?', in J Strachey (ed.), The Standard Edition of the Complete Psychological Works of Sigmund Freud: New Introductory Lectures on Psycho-Analysis and Other Works (London: Hogarth), 197-215.

Friberg, Mats (1993), 'The Need for Unofficial Diplomacy in Identity Conflicts', in Tonci Kuzmanic and Arno Truger (eds.), Yugoslavia War (2 edn.; Ljubljana, Slovenia: Austrian Study Centre for Peace and Conflict Resolution and the Schlainng Peace Institute).

Friedman, Lawrence (1969), 'On Legal Development', Rutgers Law Review, 24, 11 64.

Fry, Douglas P (2007), Beyond War: The Human Potential for Peace (New York: Oxford University Press). 
Fry, Douglas P, Bonta, Bruce D, and Baszarkiewicz, Karolina (2008), 'Learning from Extant Cultures of Peace', in Joseph de Rivera (ed.), Handbook on Building Cultures of Peace (New York: Springer).

Fukuyama, Francis (1992), The End of History and the Last Man (London Penguin).

--- (2004), State Building: Governance and World Order in the Twenty-First Century (Ithaca, New York: Cornell University Press).

--- (2005a), 'Building Democracy After Conflict: "Stateness" First', Journal of Democracy, 16 (1), 84-88.

--- (2005b), State Building: Governance and World Order in the Twenty-First Century (London: Profile Books).

--- (2008), 'State building in Solomon Islands', Pacific Economic Bulletin, 23 (3), 1834.

Fullilove, Michael (2006), 'The Testament of Solomons: RAMSI and International State-Building', (Sydney: Lowy Institute for International Policy).

Furly, Oliver and Katalikawe, James (1997), 'Constitutional Reform in Uganda: The New Approach', African Affairs, 96 (383), 243-60.

Galtung, Johan (1969), 'Violence, peace and peace research', Journal of Peace Research, 6 (3), 167-91.

--- (1975), Peace, War and Defence - Essays in Peace Research (2; Copenhagen: Christian Eijlers).

--- (1981), 'The Specific Contribution of Peace Research to the Study of Violence: Typologies', in Jean-Marie Domenach, et al. (eds.), Violence and its Causes (Paris, France: UNESCO), 83-96.

--- (1995), 'Conflict Resolution as Conflict Transformation: The First Law of Thermodynamics Revisited ', in Kumar Rupesinghe (ed.), Conflict Transformation (New York: St Martin's Press).

--- (1996), Peace by Peaceful Means: Peace and Conflict, Development and Civilization (London: Sage).

--- (2000), 'Conflict Transformation by Peaceful Means (the transcend method). Participants Manual. Trainers Manual', (New York: United Nations Disaster Management Training Programme).

Galtung, Johan and Jacobsen, Carl G (2000), Searching for Peace (London: Pluto). Gardener, James (1980), Legal Imperialism: American Lawyers and Foreign Aid in Latin America (Madison: University of Wisconsin Press).

Garry, John (2009), 'Consociationalism and its critics: Evidence from the historic Northern Ireland Assembly election 2007', Electoral Studies, 28, 458-66.

Gates, Scott, Gleditsch, Nils Petter, and Hegre, Håvard (2004), 'Towards a Global Civil Peace', Background note to the United Nations Foundation (Oslo: PRIO for United Nations Foundation).

Gault, Louisa (2003), 'The New Zealand Intervention in the Boungainville Crisis: An Integrative Cultural and Legal Rational Approach to Peace-Making in Bougainville', (University of Auckland).

Geertz, Clifford (1963), Old Societies and New States: The Quest for Modernity in Asia and Africa (New York: Free Press of Glencoe).

George, Tim (2008), 'Submission by Regional Assistance Mission to Solomon Islands Special Coordinator to the Foreign Relations Committee, National Parliament of Solomon Islands', (Honiara: RAMSI).

Ghai, Yash and Galli, Guidi (2007), 'Constitution-building Processes and Democratization: Lessons Learned', in Reginald Austin, Najib Azca, and 
Feargal Cochrane (eds.), Democracy, Conflict and Human Security: Further Reading (2; Stockholm: International IDEA), 232-49.

Ghani, Ashraf and Lockhart, Clare (2008), Fixing Failed States: A Framework for Rebuilding a Fractured World (Oxford: Oxford University Press ).

Gil-White, Francisco J. (2001), 'Are Ethnic Groups Biological "Species" to the Human Brain?', Current Anthropology, 42 (4), 515-54.

Ginsburg, Tom, Elkins, Zachary, and Blount, Justin (2009), 'Does the Process of Constitution-Making Matter?', Annual Review of Law and Social Science, 5, 201-23.

Gladwell, Malcolm (2000), The Tipping Point: How Little Things Can Make a Big Difference (Boston: Little Brown).

Glitman, Marynard (1997), 'US Policy in Bosnia: Rethinking a Flawed Approach', Survival, 38 (4), 66 - 83.

Global Business Network (2009), 'The Mont Fleur Scenarios: What will South Africa be like in the year 2002?', (7(1); Emeryville, California: Deeper News).

Gray, John (1995), Liberalism (2 edn.; Buckingham: Open University Press).

Griffiths, Hugh (1998), 'The Dynamics of Multi-National Intervention: Brcko under International Supervision', (University of Amsterdam).

Gros, Jean-Germain (1996), 'Towards a Taxonomy of Failed States in the New World Order: Decaying Somalia, Liberia, Rwanda and Haiti', Third World Quarterly, 17 (3), 455-72.

Grossman, Dave (1995), On Killing: The Psychological Cost of Learning to Kill in War and Society (Boston; Little Brown).

Group, International Crisis (2011), Europe Report No 214 - Bosnia: What Does Republika Srpska Want?

Guetzkow, Harold (1957), 'Isolation and Collaboration: A Partial Theory of International Relations', Journal of Conflict Resolution, 1, 46-68.

Guidance Note of the Secretary-General (2008), 'United Nations Approach to Rule of Law Assistance', (New York: United Nations).

--- (2009), 'United Nations Assistance to Constitution-making Processes', (New York: United Nations).

Gupta, Dipak (2001), Path to collective madness: a study in social order and political pathology (New York: Praeger Publishers ).

Gurr, Ted Robert (1981), 'Historical Trends in Violent Crime: A critical review of the evidence', Crime and Justice: A Review of Research, 3, 295-353.

Haas, Jonathan (2001), 'Warfare and the Evolution of Culture', in Gary M Feinman and Theron Douglas Price (eds.), Archaeology at the Millennium: A Sourcebook (New York: Kluwer Academic/Plenum Publishers), 329-50.

Haass, Richard N (1990), Conflicts Unending (New Haven, CT: Yale University Press).

Habermas, Jürgen (1990), Moral Consciousness and Communicative Action. (Cambridge Massachusetts: MIT Press).

--- (1997), 'Kant's Idea of Perpetual Peace, with the Benefit of Two-Hundred Years' Hindsight', in James Bohman and Matthias Lutz-Bachmann (eds.), In Perpetual Peace: Essays on Kant's Cosmopolitan Ideal (Cambridge, MA: MIT Press), 113-53.

--- (1998a), 'Citizenship and National Identity', Between Facts and Norms: Contributions to a Discourse Theory of Law and Democracy (Cambridge, Massachusetts: MIT Press), 491-516. 
--- (1998b), 'The Inclusion of the Other: Studies in Political Theory', in Ciaron Cronin and Pablo De Grieff (eds.), (Cambridge, MA: MIT Press).

Haeri, David and Blanc, Guillaume (2005), 'The 2004 Presidential Elections in Afghanistan: Lessons Learned', (United Nations: Peacekeeping Best Practices Section).

Halbrooke, Richard (1998), To End a War (New York: Random House).

Halpern, Joel and Weinstein, Harvey M. (2004), 'Empathy and Rehumanization after Mass Violence', in Eric Stover and Harvey M. Weinstein (ed.), My Neighbor, My Enemy: Justice and Community in the Aftermath of Mass Atrocity (Cambridge: Cambridge University Press), 303-22.

Hamill, James (2003), 'A Disguised Surrender? South Africa's Negotiated Settlement and the Politics of Conflict Resolution.', Diplomacy \& Statecraft, 14 (3), 1-30.

Hampson, Fen Olser (1996), Nuturing Peace. Why Peace Settlements Succeed or Fail (Washington US Institute of Peace).

Hand, Learned (1959), 'The Spirit of Liberty', in Irving Dilliard (ed.), The Spirit of Liberty: Papers and Addresses of Learned Hand (3 edn.; New York Vintage Books).

Harland, David (2005), 'UN-Peacekeeping Operations in Post-Conflict Timor-Leste: Accomplishments and Lessons Learned', (Dili: Peacekeeping Best Practice Unit, DPKO).

Harris, Nigel (1990), National Liberation (London I B Tauris \& CO Ltd).

Harris, Peter and Reilly, Benjamin (eds.) (1998), Democracy in Deep- Rooted Conflict: Options for Negotiations (Stockholm: International IDEA).

Hart, Donna and Sussman, Robert W. (2005), Man the Hunted: Primates, Predators and Human Evolution (New York: Westview).

Hart, Vivian (2003), 'Special Report: Democratic Constitution Making', (Washington: United States Institute for Peace, Report 107).

Hayner, Priscilla B. (1994), 'Fifteen Truth Commissions - 1974 to 1994: A Comparative Study', Human Rights Quarterly, 16 (4), 597-655.

Heathershaw, John (2008), 'Unpacking the Liberal Peace: The Dividing and Merging of Peacebuilding Discourses', Millennium - Journal of International Studies, 36, 597.

Heder, Stephen (1996), 'The Resumption of Armed Struggle by the Party of Democratic Kampuchea: Evidence from National Army of Democratic Kampuchea 'Self-Demobilizes", in Steven Heder and Judy Ledgerwood (eds.), Propaganda, Politics and Violence in Cambodia: Democratic Transition under United Nations Peacekeeping (Armonk, New York: M.E Sharpe), 73113.

Hegel, Georg (1967), Philosophy of Right, trans. T.M Knox (Oxford: Oxford University Press).

Hegre, Håvard (2004), 'The Limits of the Liberal Peace', (University of Oslo).

Hegre, Håvard, et al. (2001), 'Toward a Democratic Civil Peace? Democracy, Political Change, and Civil War, 1816-1992', American Political Science Review, 95 (1), 16-33.

Heininger, Janet (1994), Peacekeeping in Transition: The United Nations in Cambodia (New York: Twentieth Century Fund Press).

Helman, Gerald and Ratner, Steven (1993), 'Saving Failed States', Foreign Policy, 89 (Winter), 3-20.

Hilker, Lyndsay McLean (2009), 'Everyday ethnicities: identity and reconciliation among Rwandan youth', Journal of Genocide Research, 11 (1), 81-100. 
Hobbes, Thomas (1651), 'Leviathan', (Oxford: Clarendon Press).

Hochschild, Fabrizio (2010), 'In and Above Conflict: A Study on Leadership in the Untied Nations', (Geneva: Centre for Humanitarian Dialogue).

Hodson, Randy, Sekulic, Dusko, and Massey, Garth (1994), 'National tolerance in the former Yugoslavia', American Journal of Sociology, 99 (6), 1534-58.

Holden, Philip (2008), Autobiography and Decolonization: Modernity, Masculinity, and the Nation-State (Madison: University of Wisconsin Press).

Holmes, Richard (1985), Acts of War: Behavior of Men in Battle (London Free Press).

Holsti, Kalevi J (1999), 'The coming chaos? Armed conflict in the world's periphery', in T. V. Paul and John A. Hall (eds.), International Order and the Future of World Politics (Cambridge: Cambridge University Press ).

Holsti, Ole and Rosenau, James (1984), American leadership in world affairs (Boston: Allen \& Unwin).

Horowitz, Donald (1985), Ethnic Groups in Conflict (Berkeley, CA: University of California Press).

--- (1990), 'Making Moderation Pay: The Comparative Politics of Ethnic Management', in Joseph V. Monteville (ed.), Conflict and Peacemaking in Multiethnic Societies (Lexington: Lexington Books).

--- (1997), 'Encouraging electoral accommodation in divided societies', in Brij Lal and Peter Larmour (eds.), Electoral Systems in Divided Societies: The Fiji Constitutional Review (Canberra: Australian National University), 21-37.

--- (1998), 'Structure and strategy in ethnic conflict: A few steps toward synthesis', in Boris Pleskovic and Joseph E. Stiglitz (eds.), Annual World Bank Conference on Development Economics (345-369; Washington, DC: World Bank).

--- (2005), 'Foreward', in Ian O'flynn and David Russell (eds.), Power Sharing: New Challenges for Divided Societies (London: Pluto Press).

Howard, A E Dick (1968), The Road from Runnymede: Magna Carta and Constitutionalism in America (Charlottesville: University Press of Virginia).

--- (1991), 'The Essence of Constitutionalism', in Kenneth W Thompson and Rett R Ludwikowshki (eds.), Constitutionalism and Human Rights: America, Poland, and France: a bicentennial colloquium at the Miller Center (Lanthan, MD: University of America Press ), 3-41.

Human Rights Watch (2005), 'Human Rights Overview: Cambodia', (New York: Human Rights Watch).

--- (2010), 'World Report ', (New York: Human Rights Watch).

--- (2012), 'You Will Not Have Peace While You Are Living: The Escalation of Political Violence in Burundi', (New York: Human Rights Watch ).

Human Security Centre (2005), Human Security Report 2005: War and Peace in the 21 st Century (Oxford and New York: Oxford University Press).

--- (2010), 'Human Security Report 2009/2010: The Causes of Peace and the Shrinking Costs of War.', (Vancouver: Human Security Report Project).

--- (2011), Human Security Report 2009/2010: The Causes of Peace and the Shrinking Costs of War (New York: Oxford University Press).

Hume, David (2007), 'A Treatise of Human Nature: Volume 1', in David Fate Norton and Mary J Norton (eds.), The Clarendon Edition of the Works of David Hume (New York: Oxford University Press).

Huntington, Samuel P (1968), Political Order in Changing Societies (New Haven: Yale University Press). 
--- (1993), The Third Wave: Democratization in the late Twentieth Century (The Julian J. Rothbaum distinguished lecture series ; vol 4 Norman, London: University of Oklahoma Press).

Hurwitz, Agnès (2005), 'Chapter 11: Rule of Law Programs in Multidimensional Peace Operations: Legitimacy and Ownership', in Anja H Ebnöther and Philipp H. Fluri (eds.), After Intervention: Public Security Management in PostConflict Societies (Geneva: Geneva Centre for the Democratic Control of Armed Forces ), 333-56.

Hutchings, Kimberly (1999), International Political Theory: Rethinking Ethics in a Global Era (London Sage Publications).

Ignatieff, Michael (1993), Blood and Belonging: Journey into the New Nationalism (New York: Farrar Strauss).

Independent Monitoring Commission (2010), 'Twenty-Third Report of the Independent Monitoring Commission', (Presented to the Houses of Parliament by the Secretary of State for Northern Ireland in accordance with the Northern Ireland (Monitoring Commission etc.) Act 2003; Dublin: Independent Monitoring Commission).

International Commission of Investigation on Human Rights Violations in Rwanda (1993), 'Report of the International Commission of Investigation on Human Rights Violations in Rwanda Since October 1, 1990 ', (Joint Publication: Human Rights Watch (New York), the International Federation of Human Rights Leagues (Paris), the International Center for Human Rights and Democratic Development (Montreal) and the Interafrican Union of Human and Peoples' Rights (Ouagadougou) ).

International Commission on Intervention and State Sovereignty (2001), 'The Responsibility to Protect', (Ottawa: International Development Research Centre).

International Committee of the Red Cross (2007), 'ICRC Report on the Treatment of Fourteen "High Value Detainees" in CIA Custody', (Washington).

International Crisis Group (2003a), 'Kosovo's Ethnic Dilemma: The Need for a Civic Contract,' (Pristina \& Brussels, Balkans Report no. 143: ICG).

--- (2003b), 'Europe Report N¹44: Bosnia's Brcko: Getting In, Getting On and Getting Out', (Sarajevo and Brussels: International Crisis Group).

--- (2009), 'Europe Policy Briefing: Bosnia's Dual Crisis', (57; Sarajevo/Brussels: International Crisis Group ).

--- (2010), 'Crisis Watch No.80 - Bosnia and Herzegovina', (Brussels and Washington: International Crisis Group).

International Institute for Democracy and Electoral Assistance (2002), 'International Electoral Standards: Guidelines for Reviewing the Legal Framework of Elections', (Stockholm: International IDEA).

Issacharoff, Samuel (2004), 'Constitutionalizing Democracy in Fractured Societies', Texas Law Review, 7, 1861-94.

Jackson, Robert H (1987), 'Quasi-states, Dual Regimes and Neoclassical Theory: International Jurisprudence and the Third World', International Organization, 41 (4), 519-49.

--- (1990), Quasi-states: Sovereignty, International Relations and the Third World (Cambridge: Cambridge University Press).

Jackson, Vicki C and Tushnet, Mark (2006), Comparative Constitutional Law (2 edn.; New York: Foundation Press). 
Jacobs, Lawrence R and Shapiro, Robert Y (1994), 'Studying Substantive Democracy', PS: Political Science and Politics, 27 (1), 9-17.

Jahn, Beate (2007), 'The Tragedy of Liberal Diplomacy: Democratization, Intervention, Statebuilding (Part I)', Journal of Intervention and Statebuilding, 1 (1), 87-106.

Jaintong, Theresa (2001), 'Refugee at Last!', in Rebecca Adams (ed.), Peace on Bougainville (Wellington Victoria University Press), 101-05.

Jeffrey, Alex (2006), 'Building state capacity in post-conflict Bosnia and Herzegovina: The case of the Brcko District', Political Geography, 25 (2), 203-27.

Jeong, Ho-Won (2005), Peacebuilding in Postconflict Societies: Strategy and Process (Boulder, Colorado: Lynne Rienner).

Johnson, D, Stopka, P, and Knights, S (2003), 'The Puzzle of Human Co-operation', Nature, 421, 911-12.

Joint Standing Committee on Foreign Affairs, Defence and Trade (1999a), 'Bougainville: The Peace Process and Beyond', HoR Committee Reports (Canbebrra: The Parliament of the Commonwealth of Australia).

--- (1999b), 'Bougainville: The Peace Process and Beyond', (Canberra: The Parliament of the Commonwealth of Australia).

Jones, Lloyd (2007), 'Calls to end Solomon Islands assistance', The Australian, February 12.

Jung, Carl (1959), The Collected Works of C.G. Jung (17 volumes) (London: Routledge and Kegan Paul).

Junne, Gerd and Verkoren, Willemijn (2005), 'The Challenges of Postconflict Development', in Gerd Junne and Willemijn Verkoren (eds.), Postconflict Development: Meeting New Challenges (Boulder, Colorado: Lynne Rienner), $1-18$.

Kabui, Joseph (2001), 'Reconciliation a Priori ', in Rebecca Adams (ed.), Peace on Bougainville (Wellington: Victoria University Press), 33-44.

Kahane, Adam (2004), Solving Tough Problems: An Open Way of Talking, Listening, and Creating New Realities (San Francisco: Berrett-Koehler).

Kaldor, Mary (2001), New and Old War: Organzised Violence in a Global Era (Cambridge: Polity Press).

Kaldor, Mary and Luckham, Robin (2001), 'Global transformations and new conflicts', IDS Bulletin, 32 (2), 48-69.

Kaminski, John P. (ed.), (1995), A Necessary Evil? Slavery and the Debate Over the Constitution (Madison: Madison House Publishers).

Kandemiiri, Jonga, Zulu, Blelssing, and Nkomo, Ntungamili (2010), 'NGOs urge unity government to bring military into line on elections', Voanews, 9 November.

Kant, Immanuel (1979), 'The Conflict of the Faculties', in Mary J. Gregor (ed.), (Lincoln and London: University of Nebraska Press).

--- (1991a), 'Kant: Political Writings', in Hans Reiss (ed.), (New York: Cambridge University Press).

--- (1991b), 'Idea for a Universal History with a Cosmopolitan Purpose', in Hans Reiss (ed.), Kant: Political Writings (Cambridge: Cambridge University Press), 4153.

--- (1996a), 'On the Common Saying: That May Be Correct in Theory, but It Is of No Use in Practice', in Mary Gregor (ed.), The Cambridge Edition of the Works of Immanuel Kant: Practical Philosophy (Cambridge: Cambridge University Press), 273-309. 
--- (1996b), '"The Metaphysics of Morals: I [Rechtslehre]', in Mary Gregor (ed.), In The Cambridge Edition of the Works of Immanuel Kant: Practical Philosophy (Cambridge: Cambride Univeristy Press), 353-506.

Kapeliouk, Amnon (1982), 'Begin and the Beasts', New Statesman, June 25.

Kaplan, Robert (1993), Balkan Ghosts: A Journey Through History (New York: St Martin's Press).

Kaufman, Stuart (2006), 'Escaping the Symbolic Politics Trap: Reconciliation Initiatives and Conflict Resolution in Ethic Wars', Journal of Peace Research, 43 (2), 201-18.

Kaufmann, Chaim (1996), 'Possible and Impossible Solutions to Ethnic Civil Wars', International Security 20 (4), 136-75.

Kauona, Sam (2001), 'Freedom from Fear', in Rebecca Adams (ed.), Peace of Boungainville (Wellington: Victoria University Press), 83-94.

Keeley, Lawrence (1996), War before Civilization (New York: Oxford University Press).

Kelley, Harold H. (1973), 'The Process of Causal Attribution', American Psychologist, $28(2), 107-28$

Kelman, Herbert (1992), 'Informal Mediation by the Scholar/Practitioner', in Jacob Bercovitch and Jeffrey Rubin (eds.), Mediation in International Relations: Multiple Approaches in Conflict Management (New York: St Martin's ), 6496.

Kelman, Herbert and Cohen, Stephen (1976), 'The Problem-Solving Workshop: A Social-Psychological Contribution to the Resolution of International Conflicts', Journal of Peace Research, 2 (13), 79-90.

Kende, Mark (2002), 'The Fifth Anniversary of the South African Constitutional Court: In Defense of Judicial Pragmatism', Vermont Law Review, 26 (4), 753 68.

Kennedy, David (1988), 'A New Stream of International Law Scholarship', Wisconsin International Law Journal, 7 (1), 1-49.

King, Iain and Mason, Whit (2006), Peace At Any Price. How the World Failed Kosovo. Crises in World Politics (London: Hurst).

Kirk-Greene, Anthony M (1980), 'The Thin White Line: The Size of the British Colonial Service in Africa', African Affairs, 79 (314), 25-44.

Klaaren, Jonathan (1996), 'Executive Council, Western Cape Legislature v President of the Republic of South Africa', South African Journal of Human Rights, 12, 158-62.

Klee, Ernst, Dressen, Willi, and Riess, Volker (eds.) (1988), “The good old days": the Holocaust as seen by its perpetrators and bystanders (New York: Free Press).

Knauft, Bruce (1991), 'Violence and sociality in human evolution', Current Anthropology, 32 (4), 391-428.

Knight, Mark and Ozerdem, Alpaslan (2004), 'Guns, Camps and Cash: Disarmament, Demobilization and Reinsertion of Former Combatants in Transitions from War to Peace', Journal of Peace Research, 41 (4), 499-516.

Koonings, Kees and Kruijt, Dirk (2002), Political Armies: The Military and Nation Building in the Age of Democracy (New York and London: Zed Books).

Krasner, Stephen D. (2004), 'Sharing Sovereignty: New Institutions for Collapsed and Failing States', International Security, 29 (2), 85-120.

--- (2005), 'The Case for Shared Sovereignty', Journal of Democracy, 16 (1), 69-83.

Kriesberg, Louis (1989), 'Transforming Conflicts in the Middle East and Central Europe', in Louis Kriesberg, Terrell Northrup, and Stuart Thorson (eds.), 
Intractable Conflicts and Their Transformation (Syracuse: Syracuse University Press).

--- (1999), 'Paths to Varieties of Intercommunal Reconciliation', in Ho-Won Jeong (ed.), Conflict Resolution: Dynamics, Process and Structure (Aldershot, UK: Ashgate).

--- (2003a), 'Identity Issues ', Beyond Intractability Conflict Research Consortium, University of Colorado, Boulder, http://www.beyondintractability.org/essay/identity_issues/.

--- (2008), 'Identity Issues', Beyond Intractability November 25.

--- (2003c), Constructive Conflicts: From Escalation to Resolution (2 edn.; New York: Rowman \& Littlefield).

Krippendorf, Ekkehart (1973), 'Peace Research and the Industrial Revolution', Journal of Peace Research, 10 (3), 185-201.

Kumar, Krishna (2006), 'International assistance to promote independent media in transition and post-conflict societies', Democratization, 13 (4), 652-67.

Kymlicka, W (1995), Multicultural Citizenship (Oxford University Press).

Ladley, Andrew (2005), 'Peacekeeper Abuse, Immunity and Impunity: The Need for Effective Criminal and Civil Accountability on International Peace Operations', Politics and Ethics Review, 1 (1), 81-90.

--- (2010), 'International support for constitution-building since the end of the Cold War - what can we learn?', International Partnership for Constitution Building (International IDEA, Stockholm: Publication forthcoming).

Ladley, Andrew and Williams, Jessie (2010), 'Chapter 9 The Collier challenge: how can reliable transitional financing systems be created in 'barely functional' states?', in Manas Chatterji (ed.), Economics of War and Peace: Economic, Legal, and Political Perspectives (Contributions to Conflict Management, Peace Economics and Development, (14: Emerald Group Publishing Limited), 147-65

Lake, David (1992), 'Powerful Pacifists: Democratic-States and War', American Political Science Review, 86 (1), 24-37.

Lake, David and Rothchild, Donald (1996), 'Containing Fear: The Origins and Management of Ethnic Conflict', International Security, 21 (2), 41-75.

Langer, Walter C. (1973), The Mind of Adolf Hitler. (London: Secker and Warburg).

Lattimer, Mark (2008), 'Peoples under Threat: ' in Ishbel Matheson (ed.), State of the World's Minorities 2008 (London: Minority Rights Group International), 4555.

Layne, Christopher (1994), 'Kant or Cant: The Myth of the Democratic Peace', International Security, 19 (2), 5-49.

Leader, Nicholas and Colenso, Peter (2005), 'Aid Instruments in Fragile States', Poverty Reduction in Difficult Environments Working Paper 5 (London: UK Department of International Development (DFID)).

Leatherman, Janie, et al. (1999), Breaking Cycles of Violence (West Hartford: Kumarian Press ).

LeBlanc, Steven (2003), Constant Battles: Why We Fight (New York: St Martin's Press).

--- (2007), 'Why warfare? Lessons from the past', Daedalus, 136 (1), 13-21.

Lederach, John Paul (1995a), Preparing for Peace: Conflict Transformation Across Cultures (New York: Syracuse University Press). 
--- (1995b), 'Conflict Transformation in Protracted Internal Conflicts: The Case for a Comprehensive Network', in Kumar Rupesinghe (ed.), Conflict Transformation (New York: St. Martin's Press), 201-22.

--- (1997), Building Peace: Sustainable Reconciliation in Divided Societies (Washington: United States Institute of Peace Press).

--- (1998), 'Beyond Violence: Building Sustainable Peace', in Eugene Weiner (ed.), The Handbook of Interethnic Coexistence (New York Abraham Fund Publication).

--- (2000), 'Conflict Transformation: A Working Definition', in Carolyn SchrockShenk (ed.), Mediation and Facilitation Training Manual (Akron: Mennonite Conciliation Service).

--- (2003), The Little Books of Conflict Transformation (Intercourse, PA:: Good Books).

Lederach, John Paul and Appelby, R. Scott (2010), 'Strategic Peacebuilding. An Overview', in Daniel Philpott and Gerard F. Powers (eds.), Strategies of Peace. Transforming Conflict in a Violent World (New York: Oxford University Press), 19-44.

Lerner, Daniel (1958), The Passing of Traditional Society: Modernizing the Middle East (Glencoe, Illinois: Free Press).

Lerner, Hanna (2010), 'Constitution-writing in deeply divided societies: the incrementalist approach', Nations and Nationalism, 16 (1), 68-88.

--- (2011), Making Constitutions in Deeply Divided Societies (Cambridge: Cambridge University Press).

Levi, Primo (1987), If This is a Man and The Truce (London: Abacus Books).

--- (1989), The Drowned and the Saved (New York Vintage).

Levy, Jack S (1988a), 'Democratic Politics and War', Journal of Interdisciplinary History, 18.

--- (1988b), 'Domestic Politics and War', Journal of Interdisciplinary History, 18 (4), 653-73.

Leyton, Elliott (1997), Men of Blood:Murder in Modern England (London: Penguin Books).

Lidén, Kristoffer (2006), 'Whose Peace? Which Peace? On the Political Architecture of Liberal Peacebuilding', (Oslo University).

--- (2009), 'Building Peace between Global and Local Politics: The Cosmopolitical Ethics of Liberal Peacebuilding', International Peacekeeping, 16 (5), 616-34.

Lidén, Kristoffer, Mac Ginty, Roger, and Richmond, Oliver (2009), 'Introduction: Beyond Northern Epistemologies of Peace: Peacebuilding Reconstructed?', International Peacekeeping, 16 (5), 587-98.

Lifton, Robert Jay (1986), The Nazi Doctors: medical killing and the psychology of genocide (New York: Basic Books).

Lijphart, Arend (1977), Democracy in Plural Societies: A Comparative Exploration

(New Haven: Yale University Press).

--- (1985), 'Power-Sharing in South Africa', (Policy Paper in International Affairs No.

24; Berkley: University of California, Institute of International Studies).

--- (1990), 'The Power-Sharing Approach', in Joseph V Monteville (ed.), Conflict and Peacemaking in Multiethnic Societies (Lexington:: Lexington Books).

--- (1999), Patterns of Democracy: Government Forms and Performance in ThirtySix Countries (New Haven and London: Yale University Press). 
--- (2002), 'The Wave of Power Sharing Democracy', in Andrew Reynold (ed.), The Architecture of Democracy: Constitutional Design, Conflict Management and Democracy (Oxford: Oxford University Press), 37-54.

Lineham, Rebecca (2006), 'The Regional Assistance Mission to the Solomon Islands and democratic accountability', Masters of Strategic Studies (Victoria University of Wellington).

Linz, Juan and Stepan, Alfred (1996), Problems of Democratic Consolidation (Baltimore, MD: Johns Hopkins University Press).

Lipset, Seymour Martin (1959), Political Man: The Social Bases of Politics (New York: Doubleday and Company).

Lipset, Seymour Martin and Lakin, Jason (2004), The Democratic Century (Norman: Oklahoma University Press).

Liu, James and Hilton, Denis (2005), 'How the past weighs on the present: social representations of history and their role in identity politics', British Journal of Social Psychology, 44, 1-2.

Lizee, Pierre (1996), 'Cambodia in 195: From Hope to Despair', Asian Survey, 36 (1), 83-88.

Locke, John (1680-1690), Two Treatises of Government (1824 edn.; London: Printed for C. and J. Rivington ).

London Conference (1992), 'Statement on Bosnia', International Conference of the Former Yugoslavia (London: Doc. No LC/C5).

Long, William J and Brecke, Peter (2003), War and Reconciliation: Reason and Emotion in Conflict Resolution (Cambridge: MIT Press).

Lund, Michael (2001), 'A Toolbox For Responding To Conflicts and Building Peace', in Luc Reychler and Thania Paffenholz (eds.), Peacebuilding, A Field Guide (Boulder, CO: Lynne Rienner Publishers), 16-20.

--- (2003), 'What Kind of Peace is Being Built? Taking Stock of Post-Conflict Peacebuilding and Charting Future Directions', Prepared on the occasion of the tenth anniversary of Agenda for Peace for the International Development Research Centre (IDRC) (Ottawa, Canada).

Luttwak, Edward N (1999), 'Give War a Chance', Foreign Affairs, 78 (4), 36-44.

Lutz, Donald S (1984), 'The Relative Influence of European Writers on Late Eighteenth-Century American Political Thought ', The American Political Science Review 78 (1), 189-97.

--- (1988), The Origins of American Constitutionalism (Baton Rouge: Louisiana State University).

Lyons, Terrence (2009), 'Peacebuilding, democratization, and transforming the institutions of war', in Bruce W Dayton and Louis Kriesberg (eds.), Conflict Transformation and Peacebuilding: Moving from Violence to Sustainable Peace (New York: Routledge), 91-106.

Lyotard, Jean-François (1984), The Postmodern Condition: A Report on Knowledge (Minnesota: University of Minnesota Press).

Mac Ginty, Roger (2006a), 'Northern Ireland: A Peace Process Thwarted by Accidental Spoiling', in Edward Newman and Oliver Richmond (eds.), Challenges to Peacebuilding: Managing Spoilers During Conflict Resolution (Basingstoke: Palgrave).

--- (2006b), 'Northern Ireland: A peace process thwarted by accidental spoiling', Challenges to Peacebuilding: Managing Spoilers During Conflict Resolution (Tokyo: United Nations University), 153-72. 
--- (2006c), No War, No Peace: The Rejuvenation of Stalled Peace Processes and Peace Accords (Basingstoke: Palgrave Macmillan).

--- (2008), 'Indigenous Peace-Making versus the Liberal Peace', Cooperation and Conflict, 43 (2), 139-63.

--- (2010), 'No war, no peace: Why so many peace processes fail to deliver peace', International Politics, 47 (2), 145-62.

--- (2011), 'Hybrid Peace: The Interaction Between Top-Down and Bottom-Up Peace', Security Dialogue, 41 (4), 391-412.

Mac Ginty, Roger, Muldoon, Orla T, and Ferguson, Neil (2007), 'No War, No Peace: Northern Ireland after the Agreement', Political Psychology, 28 (1), 1-11.

MacKay, Susan (2000), Northern Protestants: An Unsettled People (Belfast: Blackstaff).

MacMillan, John (2004), 'Whose Democracy: Which Peace? Contextualizing the Democratic Peace', International Politics, 41, 472-93.

Mai, Nicola (2001), 'The archives of memory: Specific results from research in Serbia.', in Natale Losi, Luisa Passerini, and Silvia Salvatici (eds.), Archives of Memory: Supporting Traumatized Communities Through Narration and Remembrance. (Geneva: International Organization for Migration (IOM)).

Malinowski, Tom (2008), 'Restoring Moral Authority: Ending Torture, Secret Detention, and the Prison at Guantanamo Bay', The Annals of The American Academy of Political and Social Science, 618 (1), 148-59.

Malloch-Brown, Mark (2011), The Unfinished Global Revolution (London: Allan Lane).

Mamdani, Mahmood (2001), When Victims Become Killers: Colonialism, Nativism, and the Genocide in Rwanda (New Jersey: Princeton University Press).

Mandelbaum, Michael (2002), The Ideas that Conquered the World (New York: Public Affairs).

Mansfield, Anna Morawiec (2003), 'Ethnic but Equal: The Quest for a New Democratic Order in Bosnia and Herzegovina ', Columbia Law Review, 103, 2052-93.

Martin, Ian (2011), 'United Nations Post-Conflict Deployment to Libya', (United Nations).

Masamvu, Syndey and Steinberg, Donald (2009), 'If the World Hesitates, Zimbabwe Could Be Lost', The Huffington Post, May 7.

McAuley, James and Tonge, Jonathan (2007), "For God and for the Crown": Contemporary political and social attitudes amongst Orange Order members in Northern Ireland', Political Psychology., 28 (1), 33-52.

McGarry, John and O'Leary, Brendan (2004), The Northern Ireland Conflict: Consociational Engagements (Oxford Oxford University Press).

--- (2007), 'Iraq's Constitution of 2005: Liberal Consociation as Political Prescription', International Journal of Constitutional Law, 5 (4), 1-29.

McGrew, Anthony (2000), 'Democracy Beyond Borders?', in David Held and Anthony McGrew (eds.), The Global Transformations Reader: An Introduction to the Globalization Debate (Cambridge: Polity Press).

--- (2002), 'Liberal Internationalism: Between Realism and Cosmopolitanism', in David Held and Anthony McGrew (eds.), Governing Globalization: Power, Authority and Global Governance (Cambridge: : Polity Press.).

McMahon, Patrice C and Western, Jon (2009), 'The Death of Dayton: How to Stop Bosnia From Falling Apart', Foreign Affairs, 88 (5), 69-83. 
Mearsheimer, John (1990), 'Back to the Future: Instability in Europe after the Cold War', International Security, 15 (1), 5-56.

--- (1995), 'The False Promise of International Institutions', International Security, 19 (3), 5-49.

Melvern, Linda (2000), A People Betrayed: The Role of the West in Rwanda's Genocide (London: Zed Books).

Menya, Walter and Namuane, Bernard (2010), 'Commonwealth offers Kenya aid in drafting new laws', Saturday Nation, Tuesday 14 September.

Merryman, John (1977), 'Comparative Law and Social Change: On the Origins, Style, Decline and Revivial of the Law and Development Movement', The American Journal of Comparative Law, 25, 457-83.

Miall, Hugh (2004), 'Conflict Transformation: A Multi-Dimensional Task', Berghof Handbook for Conflict Transformation (Berlin: Berghof Research for Constructive Conflict Management ).

Miall, Hugh, Ramsbotham, Oliver, and Woodhouse, Tom (1999), Contemporary Conflict Resolution (Malden, MA: Polity Press).

Miller, Arthur (1952), The Crucible (Oxford: Heinemann Educational Publishers).

Milosevic, Solbodan (1989), 'Addresses Rally at Gazimestan ', Text of live relay of speech delivered at 28th June rally celebrating the 600th anniversary of the Battle of Kosovo Polje (BBC Translation: http://emperorsclothes.com/milo/milosaid2.htm, last accessed19 May 2010).

Mitchell, Christopher (2002), 'Beyond Resolution: What Does Conflict Transformation Actually Transform?', Peace and Conflict Studies, 9 (1), 1-23.

--- (2006), 'Conflict, Social Change and Conflict Resolution. An Enquiry', in David Bloomfield, Martina Fischer, and Beatrix Schmezle (eds.), Social Change and Conflict Transformation (Berlin: Berghof Research Center for Constructive Conflict Management), 13-38.

--- (2011), 'Conflict, Change and Conflict Resolution', in B Austin, Markus Fisher, and H J Giessmann (eds.), Advancing Conflict Transformation. The Berghof Handbook II (USA: Barbara Budrich Publishers), 75-100.

Mitchell, Sara McLaughlin, Gates, Scott, and Hegre, Håvard (1999), 'Evolution in Democracy-War Dynamics', Journal of Conflict Resolution, 43 (6), 771-92.

Moghadam, Valentine M (2005), 'Peacebuilding and Reconstruction with Women: Reflections on Afghanistan, Iraq and Palestine', Development, 48, 63-72.

Montagu, Ashley (1976), The Nature of Human Aggression (New York: Oxford University Press).

Montville, Joseph V (1987), 'The Arrow and the Oliver Branch: A Case for Track Two Diplomacy', in John W Mc Donald and Diana B Bendahmane (eds.), Conflict Resolution: Track Two Diplomacy (Washington, DC: US Department of State), 5-20.

Moore, Clive (2006), "'Helpem Fren" The Solomon Islands and Ramsi 2003-2006', National Presidents Forum 14 July 2006 (Sydney: Australian Institute of International Affairs).

Morales-Gamboa, Albelardo and Baranyi, Stephen (2005), '"Relative Success" in Costa Rica', in Simon Chesterman, Michael Ignatieff, and Ramesh Thakur (eds.), Making States Work: State Failure and the Crisis of Governance (Tokyo: United Nations University), 234-51.

Morris, Ian (2011), Why the West rules - for now: the patterns of history and what they reveal about the future (London: Profile Books). 
Morrison, Fred L (1996), 'The Constitution of Bosnia-Herzegovina', Constitutional Commentary, 13 (2), 145-57.

Mortlock, Roger (2001), 'A Good Thing To Do', in Rebecca Adama (ed.), Peace on Bougainville (Wellington: Victoria University Press), 69-82.

Moser, Caroline O.N. and Clark, Fiona C. (eds.) (2001), Victims, Perpetrators or Actors? Gender, Armed Conflict and Political Violence (London: Zed Books).

Mueller, John (2004), The Remnants of War (Ithaca: Cornell University Press).

--- (2009), 'War Has Almost Ceased to Exist:An Assessment', Political Science Quarterly, 124 (2), 297-321.

Muggah, Robert (2010), 'Innovations in disarmament, demobilization and reintegration policy and research: Reflections on the last decade.', (Working Paper 774; Oslo: Norwegian Institute of International Affairs).

Muller, Jan-Werner (2007), Constitutional Patriotism (Princeton, New Jersey: Princeton University Press).

Muravchik, Joshua (1996), Promoting Peace through Democracy, eds Chester A Crocker and Fen Osler Hampsen (Managing Global Chaos: Sources and Responses to International Conflict; Washington: United States Institute of Peace Press) 573-85.

--- (2002), 'Democracy's Quiet Victory', New York Times, 19 August

Mutua, Makau (1997), 'Hope and Despair for a New South African: The Limits of the Rights Discourse', Harvard Human Rights Journal, 10, 63-114.

--- (2000), 'What is Twail?', A New Stream of International Legal Scholarship

(Washington DC: American Society of International Law, Proceedings of the 94th Annual Meeting), 31-39.

Nash, Jill (1992), 'Factors Relating to Infrequent Domestic Violence Among the Nagovisi', in D Ayers Counts, J Brown, and J Campbell (eds.), Sanctions and Sanctuary: Cultural Perspectives on the Beating of Wives (Boulder Colorado: Westview Press).

Newman, Edward (2006), "'New Wars" and Spoilers', in Edward Newman and Oliver Richmond (eds.), Challenges to Peacebuilding: Managing Spoilers During Conflict Resolution (Tokyo: United Nationals University).

Newman, Edward and Richmond, Oliver (2006), 'The Impact of Spoilers on Peace Processes and Peacebuilding', Policy Brief (Tokyo: United Nations University ) .

Newman, Edward, Paris, Roland, and Richmond, Oliver (2009a), Introduction New Perspectives on Liberal Peacebuilding (Tokyo United Nations University Press).

--- (2009b), 'Introduction', New Perspectives on Liberal Peacebuilding (Tokyo: United Nations University Press), 3-25.

Nietzsche, Friedrich (2008), Beyond Good and Evil, trans. Helen Zimmern (Virginia: Wilder Publications).

Nightingale, D J and Cromby, J (eds.) (1999), Social Constructionist Psychology: a critical analysis of theory and practice (Philadelphia Open University Press).

Norell, Magnus (2008), 'Islamist Networks in Somalia: FOI Somalia Papers - Report 2', (Stockholm: Swedish Defence Research Agency).

Notter, James and Diamond, Louise (1996), 'Building Peace and Transforming Conflict: Multi-Track Diplomacy in Practice', (Washington: The Institute for Multi-Track Diplomacy: Occasional Paper Number 7).

O'Callaghan, Mary-Louise (1997), 'PNG hires mercenaries to blast rebels', Sydney Morning Herald, 22 February 
O'Connor, Tim, Chan, Sharni, and Goodman, Dr James (2006), 'Australian Aid: Promoting Insecurity', The Reality of Aid 2006: Focus on Conflict, Security and Development (London: Zed Books), 172-89.

Oberschall, Anthony (2000), 'The manipulation of ethnicity: from ethnic cooperation to violence and war in Yugoslavia', Ethnic and Racial Studies, 28 (4), 9821001 .

OECD (2007), 'Principles for good international engagement in fragile states \& situations', (Paris: Development Assistance Committee, OECD).

--- (2008), 'State-building in Fragile Situations: How Do Donors Do No Harm and Maximise Their Positive Impact', (Paris: OECD).

--- (2011a), 'Supporting statebuilding in situations of conflict and fragility', (Paris: DAC Guidelines and Reference Series).

--- (2011b), 'A new deal for engagement in fragile states', (Paris: International dialogue on peacebuilding and statebuilding).

OECD/DAC (2010), 'Peacebuilding and Statebuilding Priorities and Challenges: A Synthesis of Findings from Seven Multi-Stateholder Consultations', (Paris: OECD).

Ohmae, Kenichi (1993), 'The Rise of the Region State', Foreign Affairs, 72 (2), 78-87.

Oliver, Douglas (1973), Bougainville: A Personal History (Carlton, VIC: Melbourne University Press).

--- (1991), Black Islanders: A Personal Perspective of Bougainville 1937 (Honolulu: University of Hawaii Press ).

Oliver Richmond (2006), 'The Problem of Peace: Understanding the "Liberal Peace"', Conflict, Security and Development, 6 (3), 291-314.

Oliver Richmond and Mitchell, Audra (2012), 'Introduction - Towards a Post-Liberal Peace: Exploring Hybridity via Everyday Forms of Resistance, Agency and Autonomy', in Oliver Richmond and Audra Mitchell (eds.), Hybrid Forms of Peace: From Everyday Agency to Post-Liberalism (London: Palgrave), 1-38.

Oneal, John R and Russett, Bruce (1997), 'The Classical Liberals Were Right: democracy, interdependence and conflict, 1950 - 1985', International Studies Quarterly, 41 (2), 267-94.

--- (1999), 'The Kantian Peace: The Pacific Benefits of Democracy, INterdependence and International Organizations 1885 - 1992', World Politics, 52 (1), 1-37.

Online, Zim (2010), 'New constitution, a damp squib: NGOs', ZimOnline, Monday 25 October.

Organization for Security and Cooperation in Europe Mission to Bosnia and Herzegovina (2007), 'Lessons from Education Reform in Brcko', (October: OSCE Mission to BiH Education Department).

Osifelo, Eddie (2009a), 'Gov't-RAMSI pack takes a new stop', Solomon Star, Saturday 16 May.

--- (2009b), 'Donor banks pledge to support our budget', Solomon Star, Saturday 16 May

Ottaway, Marina (1998), 'Angola's Failed Elections ', in Krishna Kumar (ed.), Postconflict Elections, Democratization and International Assistance (Boulder and London: Lynne Rienner), 133-52.

--- (2003), 'Promoting Democracy After Conflict: The Difficult Choices', International Studies Perspectives, 3, 314-22.

Overseas Development Institute (2009), 'State-building for peace: navigating an arena of contradictions', (London: Briefing Paper 52). 
Owen, John M (1994), 'How Liberalism Produces Democratic Peace', International Security, 19 (2), 87-125.

Pacific Islands Broadcasting Corporation (2010), 'Rebel group backs Bougainville president', Islands Business Monday 17 May

Pacific Islands Forum of Eminent Persons Group (2005), 'Mission Helpem Fren - A Review of the Regional Assistance Mission to Solomon ', (Suva: Pacific Islands Forum).

Packenham, Robert (1973), Liberal America and the Third World: Political Development Ideas in Foreign Aid and Social Science (Princeton, NJ: Princeton University Press).

Paffenholz, Thania (2009), 'Understanding Peacebuilding Theory: Management, Resolution and Transformation', New Routes, 14 (2), 3-6.

Palmer, Matthew (2006), 'What is New Zealand's constitution and who interprets it? Constitutional realism and the importance of public office-holders ', Public Law Review, 17, 133-45.

Paris, Roland (1997), 'Peacebuilding and the Limits of Liberal Internationalism', International Security, 22 (2), 54-89.

--- (2001), 'Wilson's Ghost: The Faulty Assumptions of Post-Conflict Peacebuilding', in Chester Crocker, Fen Osler Hampson, and Pamela Aall (eds.), Turbulent Peace: The Challenges of Managing International Conflict (Washington: United States Institute of Peace Press), 765-84.

--- (2004), At War's End: Building Peace After Civil Conflict (Cambridge: Cambridge University Press).

--- (2006), 'Bringing the Leviathan Back In: Classical Versus Contemporary Studies of the Liberal Peace ', The International Studies Review, 8 (3), 425-40.

--- (2010), 'Saving liberal peacebuilding', Review of International Studies, 36 (2), 33765.

Paris, Roland and Sisk, Timothy D (eds.) (2009), The Dilemmas of Statebuilding: Confronting the Contradictions of Postwar Peace Operations (New York: Routledge).

Payne, James (2002), 'Violence in the Twentieth Century: A Closer Look', The Independent Review, 6 (3), 447-55.

--- (2004), A History of Force: Exploring the Worldwide Movement Against Habits of Coercion, Bloodshed and Mayhem (Sandpoint, Idaho: Lytton Publishing ).

Peacekeeping Best Practices Unit (2004), 'Lessons Learned Study on the State-Up Phase of the United Nations Mission in Libera', (New York: United Nations).

Peatling, Gary K (2004), The Failure of the Northern Ireland Peace Process (Dublin: Irish Academic Press).

Peou, Sorpong (2002), 'Implementing Cambodia's Peace Agreement', in Stephen Stedman, Donald Rothchild, and Elizabeth Cousens (eds.), Ending Civil Wars: The Implementation of Peace Agreements (Boulder, Colorado: Lynne Rienner), 499-530.

Petrovic, Edit (2000), 'Ethnonationalism and the Dissolution of Yugoslavia', in Joel Martin Halpern and David A. Kideckel (eds.), Neighbors at War: anthropological perspectives on Yugoslav ethnicity, culture, and history, (Pennsylvania: Pennsylvania State Press).

Pickering, Paula (2007), Peacebuilding in the Balkans: The View from the Ground Floor (Ithaca, New York: Cornell University Press).

Pinker, Steven (2007), 'A History of Violence', The New Republic Online 20 March

Popper, Karl (1961), The Poverty of Historicism (London: Routledge \& Kegan Paul). 
Pouligny, Béatrice (2005), 'Civil Society and Post-Conflict Peacebuilding: Ambiguities of International Programmes Aimed at Building 'New' Societies ', Security Dialogue, 36 (4), 495-510.

Pozhidaev, Dmitry (2007), 'What statements do not state', Journal of Language and Politics, 6 (3), 327-49.

Pretorius, Carole, Lokay, Peter, and Arumae, Haggai (2008), 'Solomon Islands: Public Financial Management - Performance Report', (Rotterdam: ECORYS Nederland BV).

Prunier, Gerard (1997), The Rwanda Crisis: History of Genocide (New York: Columbia University Press).

Pugh, Michael (2004), 'Peacekeeping and critical theory', International Peacekeeping, 11 (1), 39-58.

--- (2005), 'The Political Economy of Peacebuilding: A Critical Theory Perspective ', International Journal of Peace Studies, 10 (2), 23-42.

--- (2008), 'The Political Economy of Peacebuilding', in Michael Pugh, Neil Cooper, and Mandy Turner (eds.), Whose Peace? Critical Perspectives on the Political Economy of Peacebuilding (Basingstoke: MacMillan).

Pugh, Michael and Cobble, Margaret (2001), 'Non-nationalist Voting in Bosnian Municipal Elections: Implications for Democracy and Peacebuilding', Journal of Peace Research, 38 (1), 27-47.

Pugh, Michael, Cooper, Neil, and Turner, Mandy (2008), Whose Peace? Critical Perspectives on the Political Economy of Peacebuilding (London: Palgrave).

Putnam, Robert (1995), 'Bowling Alone: America's Declining Social Capital ', Journal of Democracy, 6 (1), 65-78.

Quentin-Baxter, Alison (1987), 'Independence of Western Samoa: Some Conceptual Issues', Victoria University of Wellington Law Review, 17 (5), 345-72.

Ramsbotham, Oliver, Woodhouse, Tom, and Miall, Hugh (2011), Contemporary Conflict Resolution: The prevention, management and transformation of deadly conflicts (3 edn.; Cambridge: Polity Press).

Rasmussen, Mikkel Vedby (2003), The West, Civil Society and the Construction of Peace (Basingstoke: Palgrave).

Rawls, John (1996), Political Liberalism (New York: Columbia University Press).

--- (1999), The Law of Peoples (Cambridge: Harvard University Press).

Ray, James Lee (1995), Democracy and International Conflict: An Evaluation of the Democratic Peace Proposition (Columbia: University of South Carolina Press).

Reddy, Peter (2006), 'Peace Operations and Restorative Justice: Groundwork for Postconflict Regeneration', (The Australian National University.).

--- (2008), 'Reconciliation in Bougainville: Civil war, peacekeeping and restorative justice', Contemporary Justice Review, 11 (2), 117-30.

Regan, Anthony (1998a), 'Causes and Course of the Bougainville Conflict", Journal of Pacific History, 33 (3), 269-85.

--- (1998b), 'Causes and course of the Bougainville conflict', The Journal of Pacific History, 33 (3), 269-85.

--- (2001), 'Why a Neutral Peace Monitoring Force? The Bougainville Conflict and the Peace Process', in Monica Wehner and Donald Denoon (eds.), Without a Gun: Australians' Experiences Monitoring Peace in Bougainville, 1997-2001 (Canberra Pandanus Books), 1-18.

--- (2010), Light Intervention: Lessons from Bougainville (Washington DC: US Institute of Peace Press). 
Reilly, Benjamin (2001), Democracy in Divided Societies (Cambridge, UK: Cambridge University Press).

--- (2006), Democracy and Diversity: Political Engineering in the Asia-Pacific (Oxford: Oxford University Press).

Reilly, Jacqueline, Muldoon, Orla, and Bryne, Clara (2004), 'Young Men as Victims and Perpetrators of Violence in Northern Ireland: A Qualitative Analysis', Journal of Social Issues, 60 (3), 469-84.

Reimann, Cordula (2004), 'Assessing the State-of-the Art in Conflict Transformation', The Berghof Handbook for Conflict Transformation (Berlin: Berghof Research for Constructive Conflict Management ).

Report of Coroner T. Suntheralingam (1996), 'Report and findings regarding the death of Theodore Miriung', (Port Morseby).

Report of the Secretary-General's High-Level Panel on Threats Challenges and Change (2004), 'A More Secure World: Our Shared Responsibility ', (New York: United Nations, UN Doc A/59/565).

Report of the Secretary-General (2000), 'Report of the Panel on UN Peace Operations (Brahimi Report)', (New York: United Nations).

--- (2001), 'No exit without strategy: Security Council decision-making and the closure or transition of United Nations peacekeeping operations', S/2001/394 (United Nations).

--- (2005a), 'In Larger Freedom: Towards Security, Development and Human Rights for All', (New York: United Nations).

--- (2005b), 'In larger freedom: towards development, security and human rights for all ', (New York: United Nations ).

--- (2006), 'The situation in Afghanistan and its implications for peace and security.', A/61/326-S/2006/727 (New York: United Nations).

--- (2012), 'Peacebuilding in the aftermath of conflict ', A/67/499-S/2012/746 (New York: United Nations).

Richards, David (1989), Foundations of American Constitutionalism (New York: Oxford University Press).

--- (1992), 'Revolution and Constitutionalism in America', Cardozo Law Review, 14 (3-4), 577-634.

Richardson, Lewis (1960), Arms and insecurity (Chicago: Quadrangle).

Richmond, Oliver (2005), The Transformation of Peace (Basingstoke: Palgrave).

--- (2007), The Transformation of Peace (Basingstoke: Palgrave Macmillan).

--- (2008), Peace in International Relations (London Routledge).

--- (2009a), 'A Post-Liberal Peace: Eirenism and the Everyday', Review of International Studies, 35, 577-80.

--- (2009b), 'Beyond the liberal peace? Responses to 'backsliding", in Edward Newman, Roland Paris, and Oliver Richmond (eds.), New Perspectives on Liberal Peacebuilding (Tokyo: United Nations University Press), 54-77.

--- (2010), 'A geneology of peace and conflict theory. ', in Oliver Richmond (ed.), Palgrave advances in peacebuilding: Critical develoments and approaches (New York, NY: Palgrave Macmillan), 14-40.

Richmond, Oliver and Franks, Jason (2007), 'Liberal Hubris? Virtual Peace in Cambodia', Security Dialogue, 38 (1), 27-48.

--- (2009a), Liberal Peace Transitions: Between Statebuilding and Peacebuilding (Edinburgh University Press). 
--- (2009b), 'Introduction: a Framework to Access Liberal Peace Transitions', Liberal Peace Transitions: Between Statebuilding and Peacebuilding (Edinburgh: Edinburgh University Press Ltd), 1-17.

Roberts, David (2011), 'Post-Conflict Peacebuilding, Liberal Irrelevance and the Locus of Legitimacy', International Peacekeeping, 18 (4), 410-24.

Robertson, Priscilla (1967), Revolutions of 1848: a social history (Princeton paperbacks: Princeton University Press).

Roeder, Phillip G and Rothchild, Donald (eds.) (2005), Sustainable Peace: Power and Democracy After Civil wars (Ithaca: Cornell University Press).

Rogers, Everett (1995), Diffusion of Innovation (3 edn.; New York: The Free Press).

Roscoe, Paul (2007), 'Intelligence, Coalitional Killing, and the Antecedents of War', American Anthropologist, 109 (3), 485-95.

Rose, Richard and Mishler, William (1996), 'Testing the Churchill Hypothesis: Popular Support for Democracy and Its Alternatives', Journal of Public Policy, 16 (1), 29-58.

Rose, Tore (2004), 'Reflections on Peacebuilding and the UN Development Assistance Framework', Journal of Peacebuilding and Development, 2 (3), 64-77.

Rosenn, Keith S (1990), 'Success of Constitutionalism in the United States and its Failure in Latin America: An Explanation', American Law Review 22 (1), 140.

Ross, Michael (2001), 'Does Oil Hinder Democracy', World Politics, 53 (3), 325-61.

Rostow, Walt Whitman (1971), The Stages of Economic Growth: A Non-Communist Manifesto (Cambridge: Cambridge University Press).

Rotberg, Robert (2004a), 'The Failure and Collapse of Nation-States: breakdown, prevention and repair', in Robert Rotberg (ed.), When States Fail: Causes and Consequences (Princeton: Princeton University Press).

--- (ed.), (2004b), When States Fail: Causes and Consequences (Princeton: Princeton University Press).

Rotberg, Robert I (2005), 'The failure and collapse of nation-states: breakdown, prevention and repair', in Robert I Rotberg (ed.), When States Fail: causes and consequences (Princeton New Jersey: Princeton University Press), 1-49.

Rothermund, Dietmar (2006), The Routledge Companion to Decolonisation (New York: Routledge ).

Rousseau, Jean-Jacques (1754), Discourse on the Origins of Inequality Among Men.

--- (1762), 'The Social Contract (Du Contract Social)', (1953 edn.; London: Penguin).

Rowstow, Walt (1960), The Stages of Economic Growth: A Non-Communist Manifesto (Cambridge: Cambridge University Press).

Roxborough, Ian (1988), 'Review: Modernization Theory Revisited. A Review Article', Comparative Studies in Society and History, 30 (4), 753-61.

Rubin, Barnett (2006), 'Peace building and state-building in Afghanistan: Constructing sovereignty for whose security? ', Third World Quarterly, 27 (1), 175-85.

Rummel, Rudolph (1997), Power Kills: Democracy as a Method of Nonviolence. (New Brunswick:: Transaction Publishers).

Rupesinghe, Kumar (1995), Conflict Transformation (London: Macmillan).

--- (1998), Civil Wars, Civil Peace (London Pluto).

Russett, Bruce and Oneal, John (2001), Triangulating Peace: Democracy, Interdependence, and International Organizations (New York: W.W Norton).

Russett, Bruce, et al. (1995), 'The Democratic Peace', International Security, 19 (4), 164-84. 
Russett, Bruce, et al. (1993), Grasping the Democratic Peace: Principles for a PostCold War World (Princeton: Princeton University Press).

Ryan, Stephen (2007), The Transformation of Violent Intercommunal Conflict (Hampershire: Ashgate ).

Sabaratnam, Meera (2011), 'The Liberal Peace? An Intellectual History of International Conflict Management, 1990-2010', in Susanna Campbell, David Chandler, and Meera Sabaratam (eds.), A Liberal Peace? The Problems and Practices of Peacebuilding (London: Zed Books ), 13-30.

Said, Edward (2002), The End of the Peace Process: Oslo and After (2 edn.; London Granta).

Samuels, Kirsti (2007 ), 'Constitution-Building During the War on Terror: The Challenge of Somalia', New York University Journal of International Law and Politics 40 (2), 597-614.

Samuels, Kristi and Wyeth, Vanessa Hawkins (2006), 'State-building and Constitutional Design After Conflict', (New York International Peace Academy).

Sanderson, Lt General John (1994), 'UNTAC: Successes and Failure', in Hugh Smith (ed.), International Peacekeeping: Building on the Cambodian Experience (Canberra: Australian Defence Studies Centre).

Sands, Philippe (2005), Lawless World: America and the Making and Breaking of Global Rules (London Penguin Books).

--- (2008a), Torture Team: Rumsfeld's Memo and The Betrayal of American Values (New York: Palgrave Macmillan).

--- (2008b), The Torture Team: Rumsfeld's Memo and the Betrayal of American Values (New York: Palgrave Macmillan).

Santayana, George (1905), Reason in Common Sense: The Life of Reason (1: Scribner's).

Saovana-Spriggs, Ruth (2010), 'Bougainville Women's Role in Conflict Resolution in the Bougainville Peace Process', in Sinclair Dinnen, Anita Jowitt, and Tess Newton (eds.), A Kind of Mending: Restorative Justice in the Pacific Islands (2 edn.; Canberra: ANU Press), 195-214.

Scales, Ian (2007), 'The Coup Nobody Noticed: The Solomon Islands Western State Movement in 2000', The Journal of Pacific History, 42 (2), 187-209.

Scheppele, Kim Lane (2008), 'A Constitution Between Past and Future', William and Mary Law Review, 49 (4), 1377-407.

Schrodt, Philip A., Yilmaz, Ömür, and Gerner, Deborah J. (2003), 'Evaluating "Ripeness" and "Hurting Stalemate" in Mediated International Conflicts: An Event Data Study of the Middle East, Balkans and West Africa', Annual Meeting of the International Studies Association (Portland, Oregon, USA).

Schumpeter, Joseph (1950), Capitalism, Socialism, and Democracy (New York: Harper Torchbooks).

--- (1955), 'The Sociology of Imperialism', Imperialism and Social Classes (Cleveland World Publishing), 3-98.

Schwerin, Edward (1995), Mediation, Citizen Empowerment, and Transformational Politics (Westport, CT: Praeger).

Scimecca, Joseph (1987), 'Conflict Resolution: The Basis for Social Control or Social Change', in Dennis Sandole and Ingrid Sandole-Staroste (eds.), Conflict Management and Problem Solving: Interpersonal to International Applications (New York New York University Press), 30-33.

Searle-White, Joshua (2001), The Psychology of Nationalism (New York: Palgrave). 
Security Council (1999), 'Letter Dated 15 December 1999 from the Secretary-General Addressed to the President of the Security Council', S/1999/1257 (New York: United Nations).

Seidman, Robert (1972), 'Law and Development: A General Model', Law and Society Review, 6 (3), 311-42.

Sekulic, Dusko, Massey, Garth, and Hodson, Randy (2006), 'Ethnic intolerance and ethnic conflict in the dissolution of Yugoslavia', Ethnic and Racial Studies, 29 (5), 797-827.

Selby, Jan (2009), 'The political economy of peace processes', in Michael Pugh, Neil Cooper, and Mandy Turner (eds.), Whose Peace? Critical Perspectives on the Political Economy of Peacebuilding (Palgrave Macmillan), 11-29.

--- (2013), 'The Myth of Liberal Peace-Building', Conflict, Security \& Development, 13 (1), 57-86.

Sen, Amartya (2006), Identity and Violence: The Illusion of Destiny (New York: W.W Norton \& Company Inc).

--- (2009), The Idea of Justice (London: Allen Lane).

Senghaas, Dieter (1973), 'Conflict Formations in Contemporary International Society', Journal of Peace Research, 10 (3), 163 -84.

Sharp, Gene (1973), The Politics of Nonviolent Action, 3 vols. (Boston: Porter Sargent).

Silber, Laura and Little, Alan (1996), The Death of Yugoslavia (London: Penguin Books ).

Simonsen, Sven (2004), 'Nationbuilding as Peacebuilding: Racing To Define the Kosovar', International Peacekeeping 11 (2), 289-311.

--- (2005), 'Addressing Ethnic Divisions in Post-Conflict Institution-Building: Lessons from Recent Cases', Security Dialogue, 36 (3), 297-318.

Simpson, J A, Weiner, E S C, and Press., Oxford University (1989), Oxford English Dictionary (2 edn.; Oxford Clarendon Press).

Singer, Peter (1981), The Expanding Circle: Ethic and Sociobiology (Oxford: The Clarendon Press).

--- (2002), One World: The Ethnics of Globalisation (New Haven: Yale University Press).

Sirivi, Josephine and Havini, Marilyn (eds.) (2004), As Mothers of the Land - the birth of the Bougainville Women for Peace and Freedom (Research School of Pacific and Asian Studies, Australian National University: Pandanus Books).

Sirivi, Jossie (2001), 'Finding a Voice', in Rebecca Adams (ed.), Peace on Bougainville (Wellington: Victoria University Press ), 118-24.

Sisk, Timothy (1996), Power Sharing and International Mediation in Ethnic Conflicts (Washington D.C.: United States Institute of Peace).

Sluka, Jeffrey (1992), 'An Anthropology of Conflict', in C Nordstrom and J Martin (eds.), The Paths to Domination, Resistance and Terror (Berkeley, CA: University of California Press).

Smith, David Livingstone (2007), The Most Dangerous Animal: Human Nature and the Origins of War (New York: St Martin's Press).

Smith, Peter H (1999), Talons of the Eagle: Dynamics of U.S.-Latin American Relations (Oxford: Oxford University Press).

Smith, Tony (1979), 'The Underdevelopment of Development Literature: The Case of Dependency Theory', World Politics, 31 (2), 247-88.

Smits, Jeroen (2010), 'Ethnic intermarriage and Social Cohesion. What Can We Learn from Yugoslavia?', Social Indicators Research, 96 (3), 417-32. 
Snow, David, et al. (1986), 'Frame Alignment Processes, Micromobilization, and Movement Participation', American Sociologist Review, 51 (4), 464-81.

So'o, Asofou and Fraenkel, Jon (2005), 'The Role of Ballot Chiefs (Matai Palota) and Political Parties in Samoa's Shift to Universal Suffrage', Commonwealth \& Comparative Politics, 43 (3), 333-61.

Sogavare, Manasseh (2006), 'Address to the Nation by the Prime Minister', 18 February 2007.

Sohn, Louis B (1994), Rights in Conflict: The United Nations and South Africa (New York: Transnational Publishers Inc) 63-170.

Solana, Javier (2003), 'A Secure Europe in a Better World: European Security Strategy', (Brussels: Council of the European Union).

Solarz, Stephan (1990), 'Cambodia and the International Community', Foreign Affairs, 69 (2), 33.

Solomon, Benjamin (2003), 'Kant's Perpetual Peace: A New Look at this CenturiesOld Quest', The Online Journal of Peace and Conflict Resolution, 5 (1), 10626.

Solomon Islands Government (2003), 'Framework for Strengthened Assistance to the Solomon Islands'.

Sørensen, Birgitte (1998), Women and Post-Conflict Reconstruction: Issues and Sources (The War-Torn Societies Project; Geneva: The United Nations Research Institute for Social Development and The Programme for Strategic and International Security Studies ).

South African Law Commission (1989), 'Working Paper 25 Project 58 Group and Human Rights ', (South African Law Commission).

Spies, Chris (2006), 'Resolutionary Change: The Art of Awakening Dormant Faculties in Others', The Berghof Centre Handbook Series No.5: Social Change and Conflict Transformation. (Berlin: Berghof Foundation).

Stacy, Helen (2009), Human Rights for the 21st Century (Standford: Standford University Press).

Staub, Ervin (1992), The Roots of Evil, The Origins of Genocide and Other Group Violence (Cambridge: Cambridge University Press.).

Stedman, Stephen (1991), Peacemaking in Civil War: International Mediation in Zimbabwe, 1974-1980 (Boulder, CO: Lynne Rienner).

--- (1997), 'Spoiler Problems in Peace Processes', International Security, 22, 5-53.

--- (2000), 'Spoiler Problems in Peace Processes', in Paul Stern and Daniel Druckman (eds.), International Conflict Resolution After the Cold War (Washington: National Academies Press), 178-224.

Stockholm International Peace Research Institute (2008), Summary: SIPRI Yearbook 2008 - Armaments, Disarmaments and International Security (39 edn.; Sweden: Elanders).

Svensson, Isaak and Wallensteen, Peter (2010), The Go-Between: Jan Eliasson and the Styles of Mediation (United States Institute of Peace; Washington).

Synder, Jack (2000), From Voting to Violence: Democratization and Nationalist Conflict (New York: W. W. Norton ).

Szasz, Paul C. (1997), 'The Dayton Accord: The Balkan Peace Agreement', Cornell International Law Journal 90 (3), 759-68.

--- (2000), 'Comparative Peace: A Look at Recent Peace Agreements', American Society of International Law Proceeding, 94, 298. 
Tadjbakhsh, Shahrbanou and Schoistwohl, Michael (2008), 'Playing with Fire? The International Community's Democratization Experiment in Afghanistan', International Peacekeeping, 15 (2), 252-67.

Tadjbakhsh, Shahrbanou and Richmond, Oliver (2011), 'Conclusion: typologies and modifications proposed by critical approaches', in Shahrbanou Tadjbakhsh (ed.), Rethinking the Liberal Peace: External Models and Local Alternatives (Oxon: Routledge), 221-41.

Tangri, Roger and Mwenda, Andrew M (2010), 'President Museveni and the Politics of Presidential Tenure in Uganda', Journal of Contemporary African Studies, 28 (1), 31-49.

Tapi, Robert (2002), 'From Burnham to Buin: Sowing the seeds of peace in the land of the snow-capped mountains', in Andy Carl and Sr. Lorraine Garsu CSN (eds.), Weaving consensus: the Papua New Guinea - Bougainville peace process (12; London: Conciliation Resources), 24-27.

Teitel, Ruti (1997), 'Transitional Jurisprudence: The Role of Law in Political Transformation', Yale Law Journal, 1997 (106).

Teson, Fernando R (1998), A Philosophy of International Law (Boulder, Colorado: Westview Press).

Thakur, Ramesh (2006), The United Nations, peace and security: from collective security to the responsibility to protect (Cambridge University Press).

Thayer, Nate (1997), 'The Deal That Died: negotiators thought they'd succeeded in ending the Khmer Rouge's long guerrilla war', Far Eastern Economic Review, 160 (34), 14-17.

The Organization for Security and Co-operation in Europe (2007), 'Election Observation Handbook', (5 edn.; Poland: OSCE Office for Democratic Institutions and Human Rights).

The President of the United States (2005), 'United States National Security Presidential Directive', NSPD-44 (Washington: The White House).

The United Nations (2005), 'Women \& Elections: Guide to Promoting the Participation of Women in Elections', (New York: United Nations).

Tinbergen, Nikolaas (1968), 'On War and Peace in Animals and Man', Science, 160 (1411-1418).

Toft, Monica Duffy (2009), Securing the Peace: The Durable Settlement of Civil Wars (Princeton, New Jersey: Princeton University Press).

Tohiana, Brenda (2006), 'Weaving Bougainville Together. Re-building Broken Communities: Restoring a Shattered Society', in Arlene Griffen (ed.), Lalanga Pasifika: weaving the Pacific - stories of empowerment from the South Pacific (Suva: University of the South Pacific), 164-238.

Trubek, David M and Galanter, Marc (1974), 'Scholars in Self-Estrangement: Some Reflections on the Crisis in Law and Development Studies in the United States', Wisconsin Law Review, 4, 1062.

Tushnet, Mark (1999), 'The Possibilities of Comparative Constitutional Law', Yale Law Journal, 108 (6), 1473-95.

United Nations (2003), 'Lessons Learned from United Nations Peacekeeping Experiences in Sierra Leone', (New York: Peacekeeping Best Practice Unit, DPKO).

--- (2004), 'A More Secure World: Our Shared Responsibility', (Report of the Secretary-General's High Level Panel on Threats, Challenges and Change A/59/565; New York: United Nations ). 
--- (2009), 'United Nations Policy for Post-Conflict Employment Creation, Income Generation and Reintegration', (Geneva: United Nations).

United Nations Development Programme (2005), 'Justice and Truth in Bosnia and Herzegovina: Public Perceptions - Early Warning', (Sarajevo: UNDP).

--- (2012), 'Governance for Peace: Securing the Social Contract ', (New York: United Nations).

United Nations Division for the Advancement of Women of the Department of Economic and Social Affairs (2009), 'Inventory of United Nations system activities to prevent and eliminate violence against women', http://www.un.org/womenwatch/daw/vaw.htm (New York: United Nations).

United Nations Expert Panel (2002), 'Illegal Exploitation of Natural Resources and Other Forms of Wealth of the Democratic Republic of the Congo ', (S/2002/1146; New York: United Nations Security Council).

United Nations General Assembly (1999), 'Report of the Secretary-General Pursuant to General Assembly Resolution 53/35: The Fall of Srebrenica', (New York: United Nations).

--- (2005a), 'The Peacebuilding commission: resolution/adopted by the General Assembly', (New York: United Nations, 30 December, A/RES/60/180).

--- (2005b), '2005 World Summit Outcome. Referred by the High-level Plenary Meeting of the General Assembly by the General Assembly at its fifty-ninth session', (A/60/L.1).

--- (2010), 'Review of the United Nations Peacebuilding Architecture', S/2010/393 (New York United Nations).

United Nations High Commissioner for Refugees Representation in Bosnia and Herzegovina (2009), 'Statistics Package', (UNHCR).

United Nations Peacebuilding Commission (2007), 'Strategic Framework for Peacebuilding in Burundi', (PBC/1/BDI/4 New York: UNPBC).

--- (2010), 'Emerging Lessons and Practices in Peacebuilding , 2007-2009', (New York: PBC Working Group on Lessons Learned).

United Nations Peacebuilding Support Office (2010), 'UN Peacebuilding: An Orientation', (New York: United Nations).

--- (2013), 'Peacebuilding \& The United Nations', 5 /7/2013.

United Nations Security Council (1993), 'Resolution 880 (1993) Adopted by the Security Council at its 3303rd meeting, on 4 November 1993', S/RES/880 (1993) (available at: http://www.unhcr.org/refworld/docid/3b00f166c.html (accessed 2010)).

--- (1994a), 'Resolution 940 (1994) Adopted by the Security Council at its 3413th meeting ', (UN Security Countil S/RES/940 (1994) ).

--- (1994b), 'Final Report Of The Commission Of Experts Established Pursuant To Security Council Resolution 780', (New York: United Nations S/1994/674).

--- (1999), 'Resolution 1244 (1999) Adopted by the Security Council at its 4011th meeting, on 10 June 1993', (United Nations, S/Res/1244 ).

USA (2002), 'National Security Strategy', (Department for International Development ).

van de Vyver, Johan D (1991), 'The Randolph W. Thrower Symposium, Comparative Constitutionalism: Constitutional Options for Post-Apartheid South Africa', Emory Law Journal 40, 745-834.

Van der Dennen, J MG (1986), 'Four fatal fallacies in defense of a myth: The aggression-warfare linkage', in J Wind and V Reynolds (eds.), Essays in Human Sociobiology, Vol. 2 (Brussels: V.U.B. Study Series), 43-68. 
van Evera, Stephan (1994), 'Hypotheses on Nationalism and War', International Security, 18 (4), 5-39.

van Tongeren, Paul, et al. (eds.) (2005), People Building Peace II: Successful Stories of Civil Society (London: Lynne Rienner Publishers).

Väyrynen, Raimo (1991), 'To Settle or to Transform? Perspectives on the Resolution of National and International Conflicts', in Raimo Väyrynen (ed.), New Directions in Conflict Theory: Conflict Resolution and Conflict Transformation (London: Sage), 1-25.

--- (1999), 'From Conflict Resolution to Conflict Transformation: A Critical View', in Ho-Won Jeong (ed.), The New Agenda for Peace Research (Brookfield: Ashgate Publishing).

Vetlesen, Arne Johan (2005), Evil and human agency: understanding collective evildoing (Cambridge: Cambridge University Press).

Volkan, Vamik (1997), Blood Lines: From Ethnic Pride to Ethnic Terrorism (Boulder: Westview Press).

--- (2004), Blind Trust: Large Groups and Their Leaders in Times of Crisis and Terror (Charlottesville, Virginia: Pitchstone Publishing).

von Bogdandy, Armin, et al. (2005), 'State-Building, Nation-Building, and Constitutional Politics in Post-Conflict Situations: Conceptual Clarifications and an Appraisal of Different Approaches', Max Planck Yearbook of United Nations Law, 9, 579-613.

Wainwright, Elsina (2003), 'Responding to state failure - the case of Australia and Solomon Island', Australian Journal of International Affairs, 57 (3), 485-98.

--- (2006), 'Australia's Solomon Island Commitment: How is it progressing?', The Sydney Papers 18 (1), 181- 91.

Waliggo, John Mary (1994), 'Constitution-making and the Politics of Democratisation in Uganda', in Holger Bernt Hansen and Michael Twaddle (eds.), From Chaos to Order (Kampala: Foundation Publishers Ltd).

Wallensteen, Peter (2007), Understanding Conflict Resolution: War, Peace and the Global System (London: Sage).

Wallerstein, Immanuel M (1976), The Modern World System: Capitalist Agriculture and the Origins of the European World-Economy in the Sixteenth Century (New York Academic Press).

--- (1984), The Politics of the World-Economy: The States, the Movements, and the Civilizations. (Cambridge University Press; Cambridge).

Waltz, Kenneth (1993), 'The Emerging Structure of International Politics', International Security, 18 (2), 44-79.

--- (2002), 'Structural Realism after the Cold War', in G John Ikenberry (ed.), America Unrivaled: The Future of the Balance of Power (Ithaca: Cornell University Press), 29-67.

Walzer, Michael (1996), 'The Hard Questions: Vote Early', New Republic, 215 (18), 29.

Warner, Daniel (2003), 'The Responsibility to Protect and Irresponsible, Cynical Engagement', Millennium - Journal of International Studies, 32 (1), 109-21.

Watson, James (2005), 'A model Pacific solution? A study of the deployment of the Regional Assistance Mission to Solomon Islands', (Canberra: Land Warfare Studies Centre, Department of Defence. Working Paper No. 126).

Weart, Spencer R. (1998), Never at War: Why Democracies Will Not Fight One Another (New Haven: Yale University Press ). 
Weber, Max (1947), 'The Theory of Social and Economic Organization', (1964 edn.; New York: The Free Press).

Wehr, Paul, Burgess, Heidi, and Burgess, Guy (eds.) (1994), Justice Without Violence (Boulder: Lynne Rienner).

Welsh, David (1994), 'Negotiating a Democratic Constitution', in J.E.Spence (ed.), Changes in South Africa (London Royal Institute of International Affairs), 25.

Wheare, Kenneth (1966), Modern Constitutions (New York: Oxford University Press).

Whipps, Heather (2006), 'Anthropologists: Early Humans Probably Peaceful', LiveScience, Fox News.

Widner, Jennifer (2008), 'Constitution Writing in Post-Conflict Settings: An Overview', William and Mary Law Review, 49 (4), 1513-41.

Wiesel, Elie (1982), Night (25 edn.; New York: Bantam Books).

--- (1994), All Rivers Run to the Sea (London: Harper Collins Publishers).

Willett, Susan (2006), 'Global Security, the Liberal Peace, and Human Security. ', Economists for Peace and Security Quarterly, 18 (4), 1-5.

Williams, Phil and Picarelli, John (2005), 'Combating Organized Crime in Armed Conflict', in Karen Ballentine and Heiko Nitzschke (eds.), Profiting from Peace: Managing the Resource Dimensions of Civil War (Boulder, Colorado: Lynne Rienner), 123-52.

Wilson-Roberts, Guy (2001), 'The Boungainville Conflict, An Historical Overview', in Rebecca Adams (ed.), Peace on Bougainville (Wellington: Victoria University Press).

Winter, John, Schofield, Kaye, and Duituturaga, Emele (2008), 'Annual Performance Report 2007/2008: A Report on the Performance of the Regional Assistance Mission to Solomon Islands', (Honiara: RAMSI).

Woods, Emira (1997), 'Somalia', (Washington: Foreign Policy In Focus).

Woodward, Bob (2006), State of Denial (New York: Simon \& Schuster Paperback).

Woodward, Susan (2002), 'Economic priorities for successful peace implementation', in Stephen Stedman, Donald Rothchild, and Elizabeth Cousens (eds.), Ending Civil Wars: The Implementation of Peace Agreements (Boulder, Colorado: Lynne Rienner), 183-214.

Woolf, Leonard (1916), International Government (London: G Allen \& Unwin Limited).

World Bank (2003), 'The Role of the World Bank in Conflict and Development: An Evolving Agenda', (Washington: Conflict Prevention and Reconstruction Unit).

--- (2011), 'World development report 2011: Conflict, security, and development', (Washington, DC).

Wrangham, Richard (1999), 'Evolution of Coalitionary Killing', Yearbook of Physical Anthropology, 42, 1-30.

Wrangham, Richard and Peterson, Dale (1996), Demonic Males: Apes and the Origins of Human Violence (New York: Houghton Mifflin Harcourt).

Wright, Robert (2001), Nonzero: The Logic of Human Destiny (New York: Random House).

Zartman, William (1985), Ripe for Resolution: Conflict and Intervention in Africa (New York: Oxford University Press).

--- (1995), Elusive Peace: Negotiating an End to Civil Wars (Washington: The Brookings Institution). 
--- (2000), 'Ripeness: The Hurting Stalemate and Beyond', in Paul Stern and Daniel Druckman (eds.), International Conflict Resolution After the Cold War (Washington: National Academy Press).

--- (2001), 'The Timing of Peace Initiatives: Hurting Stalemates and Ripe Moments', The Global Review of Ethnopolitics, 1 (1), 8-18.

Zurcher, Christoph (2011), 'The Liberal Peace: A Tough Sell?', in S.P Campbell and D Chandler (eds.), The Liberal Peace? The Problems and Practices of Peacebuilding (London Zed Books), 69-88. 